



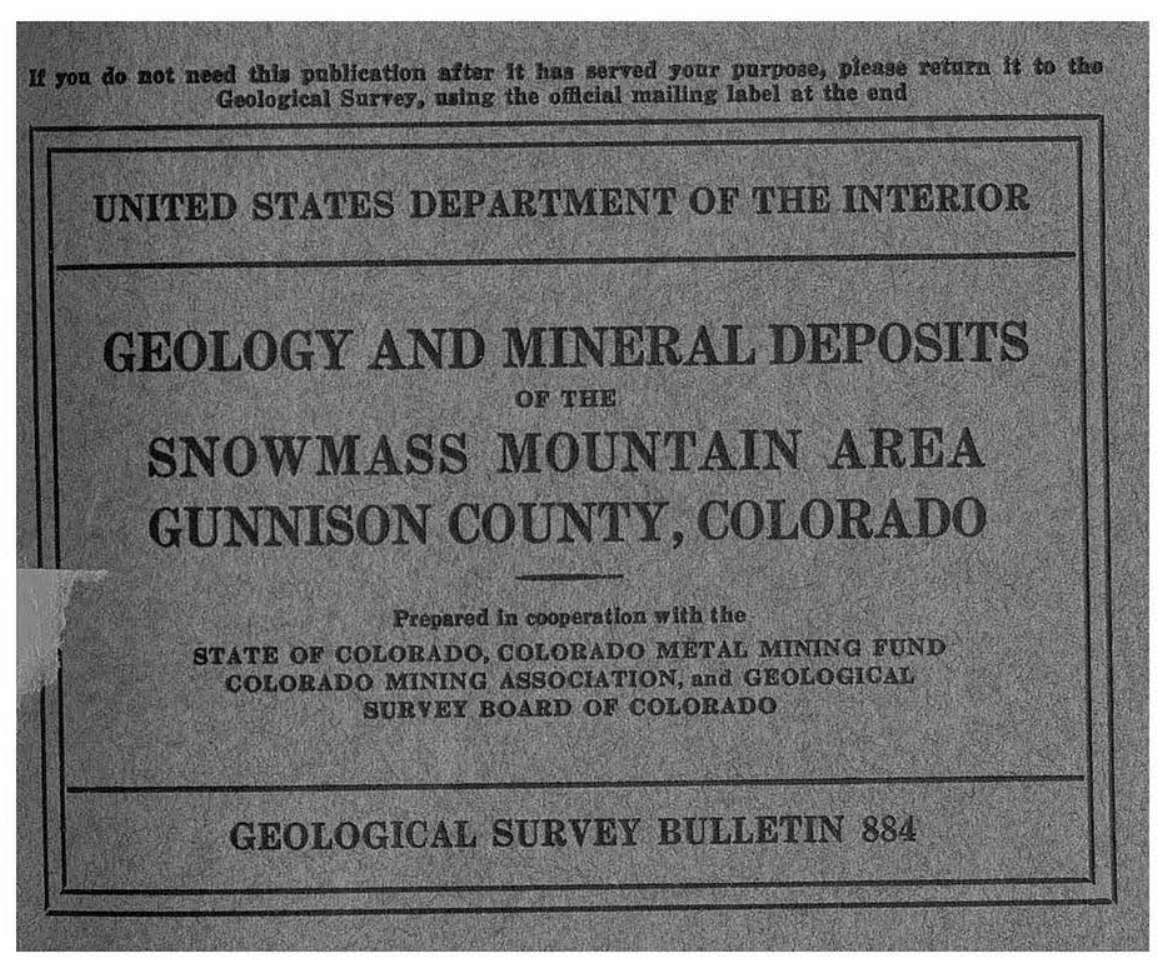



UNITED STATES DEPARTMENT OF THE INTERIOR

Harold L. Ickes, Secretary

GEOLOGICAL SURVEY

W. C. Mendenhall, Director

Bulletin 884

\section{GEOLOGY AND MINERAL DEPOSITS \\ OF THE SNOWMASS MOUNTAIN AREA GUNNISON GOUNTY, COLORADO}

BY

JOHN W. VANDERWILT

Prepared in cooperation with the

STATE OF COLORADO, COLORADO METAL MINING

FUND, COLORADO MINING ASSOCIATION

and GEOLOGICAL SURVEY BOARD

OF COLORADO

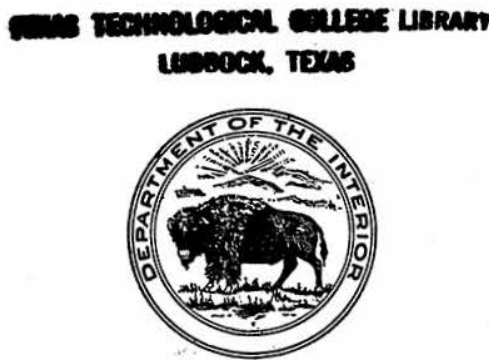

UNITED STATES

GOVERNMENT PRINTING OFFICE

WASHINGTON : 1937

For sale by the Superintendent of Documents, Washington, D. C.

Price $\$ 1.00$ (Paper)

\section{LIBRARY}

TEXAS TECHNOLOGICAL COLLEGE

. IRROCK TEXAS 


\section{CONTENTS}

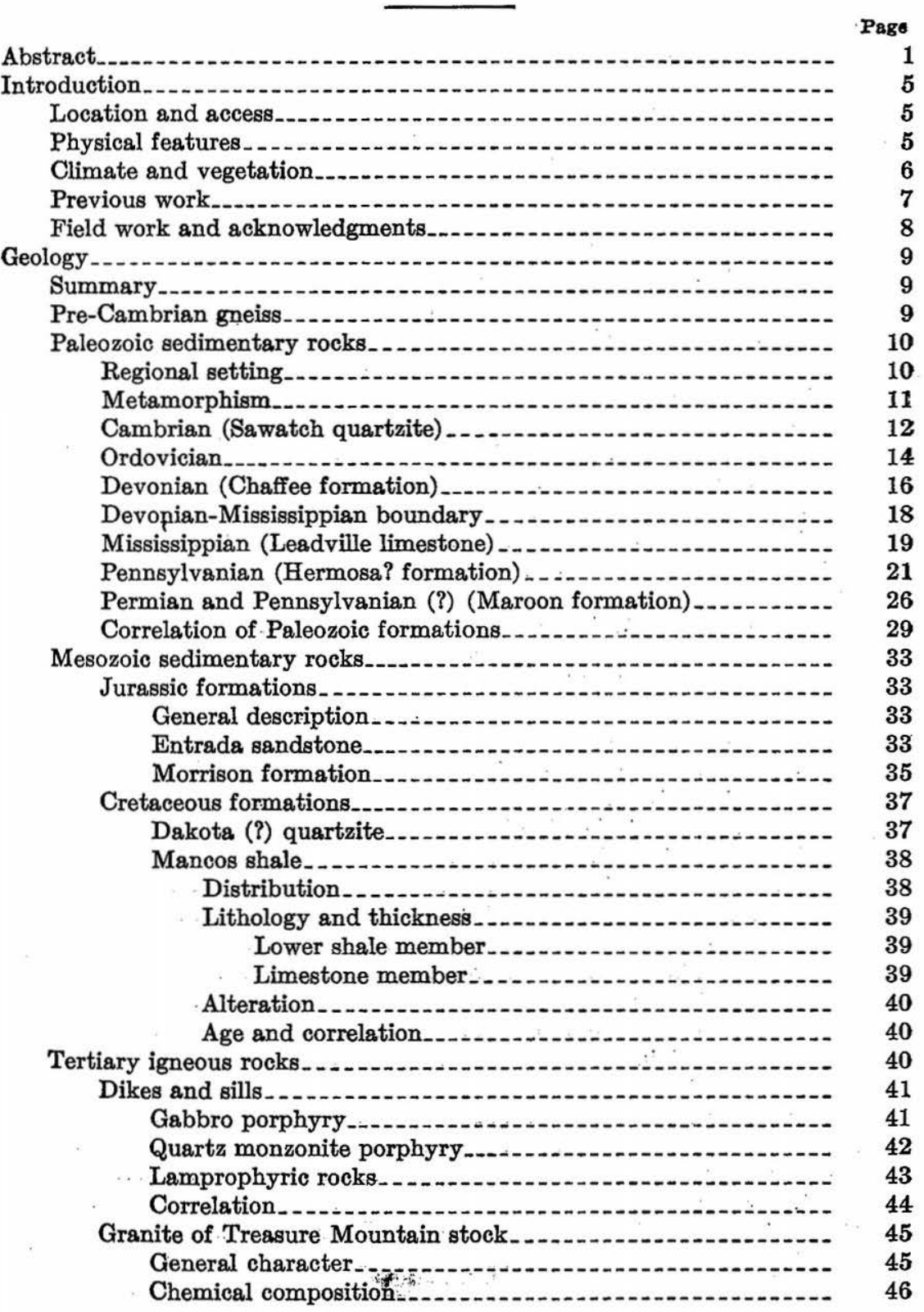


Geology-Continued.

Tertiary igneous rocks-Continued.

Granite of Treasure Mountain stock-Continued. Page

Mode of occurrence....... 48

Form of body of intrusion

Emplacement............. 49

Pegmatites, aplites, and porphyritic marginal facies...- $\quad 50$

Metamorphism_..... 50

Conclusions_..-

Relative age and correlation

Granodiorite of Snowmass Mountain stock _............ 52

Location and access__-_._. 52

Relation to neighboring stocks........... 52

Different rock varieties...-....... 53

Quartz diorite

Albite granite..... 55

Granodiorite

Changes from margin toward center............... 59

Origin of albite granite and other rock varieties.......... 64

Mode of occurrence........ 68

Correlation. -

Contact metamorphism

Genersl features_._. 70

Pre-Cambrian gneiss_..._. 71

Dikes and sills_...

Shale.-1

Quartzite_... 73

Dolomite...

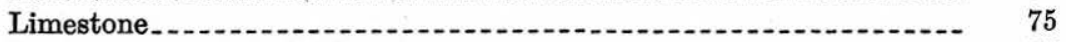

Sandy shale and shaly limestone

Influence of structure on metamorphism

Origin of metamorphic silicates_._. 79

Structure_-_.

General features.......... 80

Pre-Jurassic angular unconformity

Structure of Tertiary rocks. _.

Northeast trend of early dikes..... 82

Elk Mountain fault zone......... 83

Treasure Mountain dome

Size and form

Faults_............ 93

Characteristic features.... 93

Whopper fault.

Lack of continuity

Origin

Relative age

Summary

Glaciation_.......... 96

Depositional features........ 96

Erosional features

Conclusions_... 100

Ore deposits. -

General summary

Minerals_... 
Ore deposits-Continued. Page

Character...

Veins

Bedded replacement deposits_............ 110

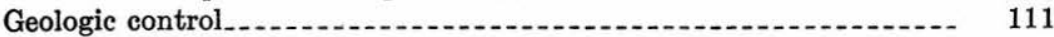

Faulting and metamorphism

Character and composition of rock 112

Zoning

Conclusions_.

Mines and prospects... 114

Northern part of area

Sheep Mountain

Black Eagle.......... 114

Black Queen mine....... 115

Catalpa__.

Evening Star

Gold Pan vein

Inez tunnel._.

Lizard Lake........... 121

Lucky Boy

Milwaukee-Undine group.

Pioneer (Warrior) tunnel.................. 123

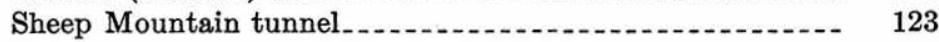

Tennessee of the Black Queen group.-_..- 125

Lead King Basin

Lead King mine.

Mineral Point_.

Daisy

Belle of Titusville_._.

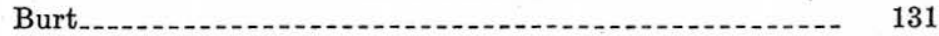

Bear Mountain tunnel.............. 132

Treasure Mountain

Lead Bullet....... 134

Skyline_. -

Yule Creek

Crystal Mountain tunnel._._.

Harris-Farley and High Tide vein group.

Southern part of area

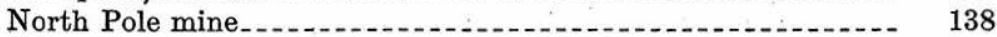

Galena Mountain........ 141

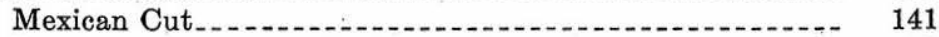

Blue Jay tunnel_...

Rockett tunnel......... 142

Homestake tunnel.................. 142

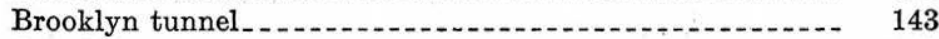

Schofield Park

Whopper lode........ 144

John Baroni tunnel.

Hercules-Ajax mine .

Treasury Mountain .

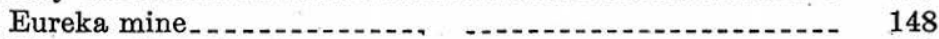

Head of Yule Creek .

Paradise Pass and vicinity

Bennet tunnel.

Molybdenite prospects. 


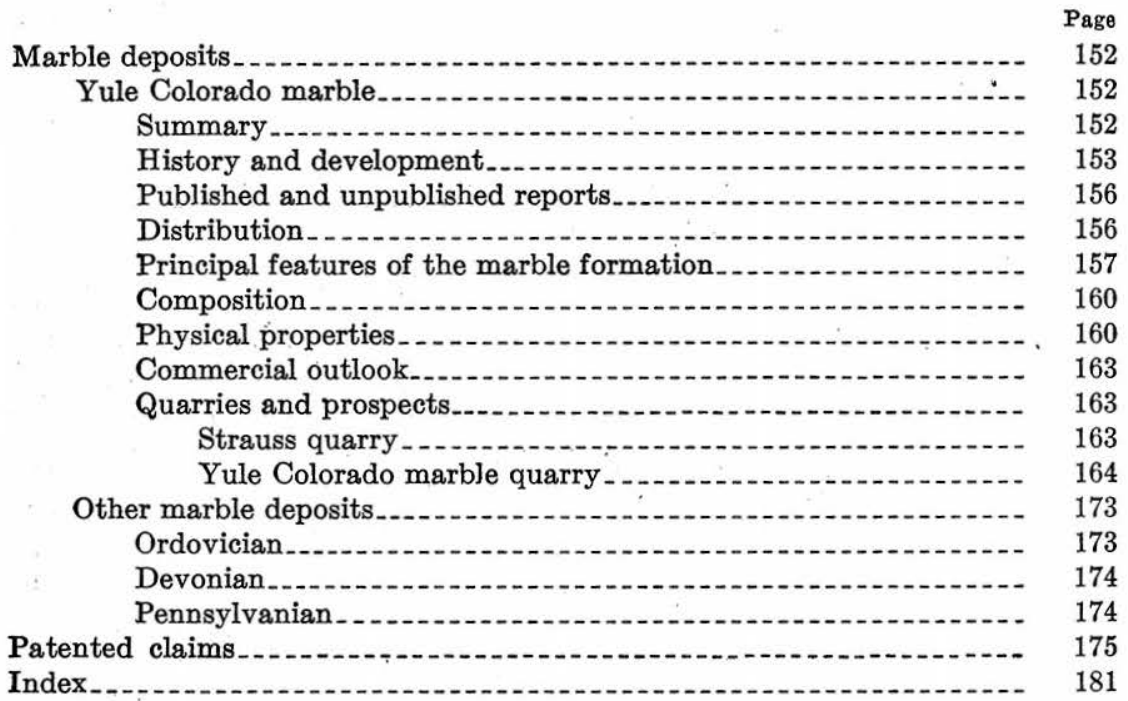

\section{ILLUSTRATIONS}

Plate 1. Geologic map of Snowmass Mountain area, Colorado, with cross sections and oversheets showing claims and glacial

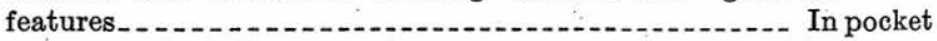

2. $A$, Ridge of Cambrian (Sawatch) quartzite forming the wall of a cirque on the southwest flank of Treasure Mountain; $B$, Characteristic bluff of Ordovician (Manitou) dolomite on the slope southeast of Whitehouse Mountain; C, Banding characteristic in outcrops of weathered surfaces of Manitou dolomite

3. $A$, Interbedded dolomite, dolomitic limestone, and limestone in the lower part of the Mississippian (Leadville) limestone on east slope of Whitehouse Mountain, total thickness about 200 feet; $B$, Bedding brought out by weathering of upper part of Mississippian (Leadville) limestone calcite marble southeast of saddle south of Whitehouse Mountain

4. A, Prominent white Hermosa (?) Pennsylvanian conglomerate consisting of well-rounded limestone pebbles in a limestone matrix, both of which are well marbleized, west slope of Crystal Peak east of Bear Basin; $B$, Limestone (marble) conglomerate of the Hermosa (?) formation shown in $A$.....

5. A, Typical exposure of unmetamorphosed Maroon strata, east face of Maroon Peak; $B$, Typical exposure of metamorphosed Maroon strata, looking up North Fork of the Crystal River into Lead King Basin.

$A$, Jurassic rocks and Cretaceous Dakota (?) quartzite and Mancos shale overturned along Elk Mountain fault and in their normal position along the Crystal River on the northeast flank of Treasure Mountain dome; $B$, Rugged topography and high relief formed by resistance to erosion of rock of the

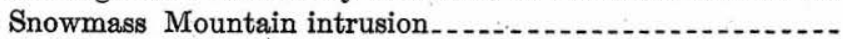


Plate 7. $A$, Indurated Mancos shale on west slope of Cinnamon Mountain, showing typical mode of disintegration into blocky fragments; $B$, Sheet jointing in granite near its contact with

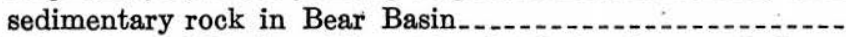

8. A, East slope of Big Bear Mountain; $B$, Photomicrograph showing calcite in granodiorite of Snowmass Mountain intrusion.-

9. Contact of granodiorite of Snowmass Mountain intrusion and Maroon grits north of Snowmass Lake

10. A, Contact of granodiorite of Snowmass Mountain intrusion and Maroon grits southwest of Snowmass Lake; $B$, View along northward continuation of Elk Mountain fault zone on Thompson Creek about 15 miles northwest of 'Marble......-

11. $A$, Banded serpentinized Manitou (Ordovician) dolomite; $B$, Ribbed pattern produced by weathering of metamorphosed Dyer (Devonian) dolomite containing irregular bands of diopside; $C$, Ribbed pattern produced by weathering of unaltered Dyer (Devonian) dolomite from the Alma district, Park County, Colo

12. $A$, Marbleized dolomitic limestone in Mississippian (Leadville) limestone encountered in the Yule Colorado marble quarry; $B$, A part of silicified (lime) areas found in Mississippian (Leadville) limestone..........................

13. A, Coarse gray calcite occurring in veins and as matrix of white marble; $B$, Glacial grooves in Devonian dolomite in Yule Creek a little east of the Yule Colorado quarry ...........-

14. A, Angular unconformity between the Paleozoic and Jurassic formations as exposed near the head of Yule Creek on the south side of the valley; $B$, Elk Mountain fault zone exposed on northwest side of the east fork of Rock Creek east of Schofield Park

15. Elk Mountain fault zone, according to Holmes..........

16. $A$, Treasure Mountain dome as seen from the north; $B$, Treasure Mountain dome as seen from the east.................

17. A, Glaciated benches on Maroon red beds northwest and southeast of Little Snowmass Lake; $B$, Glaciated bench cut in gneiss along Yule Creek

18. $A$, Intergrowth of specularite and barite; $B$, Poorly formed galena crystals from a cavity in sphalerite, Lucky Boy tunnel......-

19. $A$, Stringers of angular chert fragments; $B$, Segregations of specularite in quartz

20. $A$, Irregular mass of dolomite in white calcite marble; $B$, Cross section of parts of a lens of diopside and quartz . . . . . ...-

21. "Yule golden vein" ashlar, with "Belgian black" base, Providence County Courthouse, Providence, R. I..............

22. "Yule golden vein" fluted pilasters and frieze course, with "Loredo Chiaro" panels and "Belgian black" base, Field

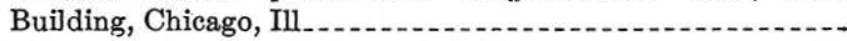

23. "Yule veined statuary" (second statuary) walk and trim, with Italian "black and gold" base, Fidelity Building, Los Angeles, Calif

24. Cliff of white marble showing position of Yule Colorado marble quarry 
FIGURE 1. Index map showing location of Snowmass Mountain area

2. Columnar sections of Pennsylvania Hermosa (?) beds measured on Whitehouse Mountain and on Treasury Mountain... -.

3. Correlation of pre-Pennsylvanian rocks on Treasure Mountain

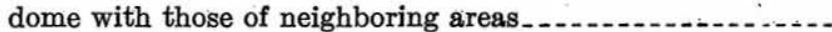

4. Generalized section showing granite cutting across all the prePennsylvanian formations and into pre-Cambrian gneiss ....

5. Graphic presentation of rock varieties of Snowmass Mountain stock

6. Map showing Elk Mountain fault zone and Castle Creek fault at Aspen, in relation to the Grand Hogback monoclinal fold and to the intrusions of granodiorite in the Elk Mountains..

7. Diagrammatic cross sections of structure types along the Elk Mountain-Grand Hogback zone of deformation

8. Black Queen mine .

9. Gold Pan vein and fault in Dakota (?) quartzite . . . . . 118

10. Inez tunnel

11. Pioneer (Warrior) tunnel. 123

12. Sheep Mountain tunnel_.

13. $A$, Tunnel of Lead King mine; $B$, Lower barren prospect tunnel, Lead King mine

14. Belle of Titusville tunnels _....... 130

15. Burt tunnels.

16. Bear Mountain tunnel_...

17. Zinc prospect on Yule Creek about a mile southeast of Yule Colorado marble quarry

18. Crystal Mountain tunnel_.......... 137

19. North Pole tunnel......... 140

20. Brooklyn tunnel

21. John Baroni tunnel........ 146

22. Hercules-Ajax mine

23. Block diagram showing relation of the joint systems, chert bands, and dolomitic bodies found in the Yule Colorado

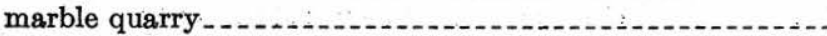




\title{
GEOLOGY AND MINERAL DEPOSITS OF THE SNOWMASS MOUNTAIN AREA, GUNNISON COUNTY, COLORADO
}

\author{
By JOHN W. VANDERWILT
}

\begin{abstract}
The Snowmass Mountain area is in the Elk Mountains, immediately north of the Crested Butte and Anthracite quadrangles, in the extreme northern part of Gunnison County, Colo. Mineral deposits were recognized in the early seventies; in early literature the area is referred to as the Rock Creek mining district, but it is now known as the Crystal River district.

The maximum relief is a little over 5,000 feet, with rugged divides and steep slopes on which the geologic features are well exposed by glaciation and subsequent stream erosion.

Pre-Cambrian gneiss, the Paleozoic formations common to central Colorado, Jurassic and Cretaceous formations, and intrusions of Tertiary age are exposed in the area. The gneiss is composed largely of feldspar and biotite and is typical of the pre-Cambrian over large areas in the Sawatch Range, to the east. Sawatch quartzite (Cambrian), 219 to 278 feet thick, rests on the gneiss and is in turn overlain by 81 to 151 feet of Manitou (Ordovician) dolomite. Several feet of Harding quartzite and 60 to 63 feet of Fremont limestone constitute the upper part of the Ordovician. No Silurian is present. The Parting member, the basal part of the Devonian Chaffee formation, is composed of about 54 feet of shales, shaly limestones, and dolomites and several feet of quartzite. The upper part of the Chaffee formation, the Dyer dolomite member, is $\mathbf{7 2}$ to 97 feet thick and is overlain by 170 to 274 feet of Leadville (Mississippian) limestone. The lower part of the Leadville is interbedded dolomite and limestone through an interval of about 40 feet, above which the formation is a massive limestone. On the Leadville limestone rests the Hermosa (?) formation (Pennsylvanian), composed of 1,228 to 1,316 feet of limestone, sandstone, shale, and rocks of intermediate composition. A breccia of chert and quartzite fragments in shale forms the basal bed of the Hermosa and rests on an erosional unconformity. Above the Hermosa are more than 3,000 feet of Pennsylvanian (?) and Permian strata (Maroon formation), terminated at the top by a strong angular unconformity at the base of the Entrada sandstone (Jurassic), 30 to 40 feet of which in places underlies the Morrison formation (Jurassic), which is about 400 feet thick. Dakota (?) quartzite (Cretaceous), 100 to 150 feet thick, rests on the Morrison, and above the Dakota (?) are Mancos (Cretaceous) shales. Only the lower part of the Mancos shale is present.

All the formations are well developed except the Harding quartzite and Fremont limestone, both of which are relatively thin and represent the
\end{abstract}


northernmost exposures of these beds in central Colorado. The formations can be satisfactorily correlated with those of neighboring areas, including Glenwood Springs, the Crested Butte quadrangle, and the Aspen mining district.

The igneous rocks in the area are of Tertiary age. The oldest are dikes and sills of intermediate composition, after which stocks of granodiorite (Snowmass Mountain) and albite granite (Treasure Mountain) came into place. The albite granite and granodiorite may represent differentiates of a common batholith. The relative ages of the stocks are not known.

The dikes and sills are small. They are confined largely to the southern part of the area and represent the northern ends of dikes and sills of the Anthracite and Crested Butte quadrangles. The dike rocks are all porphyritic and consist of quartz monzonite similar to the Lincoln porphyry of the Mosquito Range, gabbro, lamprophyric rocks, and white felsitic rock. All are more or less altered, and identification is not always possible.

The granodiorite is a stock covering about 40 square miles, most of which lies north of the area. It forms rugged peaks, of which Snowmass Mountain is a representative example. The rock is medium-grained and very uniform in appearance over large areas. It is composed of quartz, orthoclase, oligoclase, and biotite. Marginal facies of the granodiorite are quartz diorite and albite rock in which all the feldspar is albite. The quartz diorite occurs opposite the Maroon formation and is confined to a zone not more than a few hundred feet wide. The albite rock, not to be confused with the albite granite of Treasure Mountain, oceurs in a zone several hundred feet wide opposite the Mancos shale and in the area where the intrusion has cut across the Elk Mountain fault zone. The principal minerals are albite and quartz with much biotite and some calcite. The complete absence of veins of any kind and the presence of limestone inclusions has led to the belief that the albite granite was formed in the magmatic stage of the intrusion by mineralizers, probably water and carbon dioxide, derived from the sedimentary rocks. The chief role of the sedimentary inclusions would be to furnish mineralizers in sufficient volume and concentration to cause the concentration of the albite molecule during the magmatic stage; ordinarily the concentration of mineralizers is effected relatively late, as albitization more commonly occurs after a magma is almost completely solidified. The early existence of an albitic magma finds support in the occurrence of albite-aplite dikes and other albitic dikes and sills in the Aspen district.

The albite granite is exposed over a relatively small area, but the areal extent of associated metamorphic rocks is proof of the stocklike nature of the mass. The intrusion arched the formations in the form of an elongate dome and at the same time cut across 1,500 to 2,000 feet of strata. The granite is a pink medium-grained rock composed of quartz, orthoclase, albite, and a small amount of biotite. The marginal facies is porphyritic, with phenocrysts of pink orthoclase and quartz in a pale-pink to white groundmass. Biotite is entirely lacking in places in this marginal porphyritic facies, which ranges in width from a few inches to several hundred feet. The bulk of the mass is well crystallized, and at the crest of the stock pegmatites of orthoclase and quartz are common. The granite is virtually unaffected by metamorphism.

The outstanding structural features, named in order of their relative age, are an angular unconformity at the base of the Jurassic; the Elk Mountain fault zone; the granodiorite stock, of which Snowmass Mountain is a part; and the Treasure Mountain dome, formed by the intrusion of a stock of albite granite.

The beveled edges of the beds below the unconformity at the base of the Jurassic trend N. $40^{\circ}-50^{\circ} \mathrm{W}$. and dip $20^{\circ}-28^{\circ} \mathrm{NE}$., relative to the base of the 
Jurassic reduced to a horizontal plane. The surface of the unconformity is remarkably uniform.

The Elk Mountain fault zone trends northwest across the area. Along it the Maroon red beds are thrown up against and above 1,000 feet of overturned Mancos shale. The structure is continuous to the northwest with the Grand Hogback fold, on the flank of the White River Plateau; to the southeast it extends at least as far as the Gunnison River. The strike in the area is northwest. It changes to nearly west for several miles northwest of the area, and beyond that it changes to more nearly north. Thrust or reverse faulting is confined to the Snowmass Mountain area; farther northwest the beds lie in a monoclinal fold with normal faults. Local variations in structural detail are dependent on the changing curvature along the strike of the fault zone; the beds are steepest in the areas between the points of maximum curvature. Three large stocks of granodiorite are localized along the Elk Mountain fault zoneWhitehouse Mountain lies to the southeast, Snowmass Mountain within the mapped area, and Mount Sopris to the northwest of the area.

The granodiorite of Snowmass Mountain cuts across the Elk Mountain fault zone; however, the main mass of the stock lies on the northeast side. Where the intrusive mass cuts across the strike of the beds along the fault zone the rocks are crushed and broken for a width of several hundred feet; elsewhere the beds are arched and the bedding is cut at a small angle.

An intrusion of granite brought about the exposure of pre-Cambrian gneiss and all the earlier Paleozoic beds, for it arched the beds into a sharp dome and thus brought them within reach of erosion. Treasure Mountain marks the crest of the dome, which is 3 to 5 miles wide and 5 to 6 miles long, with its major axis trending northwestward. Only a relatively small area of the albitic granite is exposed, but the extent of metamorphism suggests a wider distribution of the granite at depth. All the formations below the Dakota (?) quartzite are uniformly metamorphosed, whether close to the contact or several thousand feet from it. The principal changes are from shale to hornfels, from sandstone to quartzite, from dolomite beds to serpentinized rock that contains much diopside, and from limestone to white marble. In addition, epidote, andradite garnet, and hedenbergite are common in places. The formation of serpentine and diopside has been controlled so closely by the composition of individual beds that these minerals constitute a guide for the identification of horizons in the metamorphic areas.

The area has been glaciated at two stages. The first or high stage is marked by cut-rock benches near the heads of the valleys and by glacial boulders several hundred feet above the benches that were traced as far as Redstone, 12 miles northwest of the area. The second stage filled the lower parts of the present valleys. At the heads of the valleys continuous glaciation may have occurred.

Among the ore deposits zinc-lead ores predominate, although copper-silver and native silver ores also have been productive. The deposit of Colorado Yule marble has been and promises to continue to be commercially more productive than the metals. The total value of the output of metals has been about $\$ 500,000$, and that of marble several million dollars. Authentic data on production are lacking for both industries. The bulk of the metals came from four mines-the Eureka mine, on Treasure Mountain, and the North Pole mine, in North Pole Basin, both of which produced copper-silver ore; the Black Queen mine, on Sheep Mountain, which produced considerable native silver ore; and the Lead King mine, which produced lead-zinc ore and some silver ore. All the marble has come from one quarry, which was opened in 1908. 
Ore deposits are confined to the structural dome of Treasure Mountain and are concentrated on the northeast flank of the dome in a faulted and fissured zone 1 to 3 miles wide and 8 miles long. The zone contains sedimentary beds of Pennsylvanian, Permian, Jurassic, and Cretaceous age. The granite that formed the dome has cut out all the early Palezoic beds in this part of the dome, but they are present on the crest of the dome and to the southwest. All the beds were metamorphosed prior to sulphide deposition.

The process of mineralization included three major stages, each of which graded into the succeeding one-first, intrusion of "the granite of Treasure Mountain, which caused faulting and metamorphism of the overlying Paleozoic and Cretaceous beds; second, deposition along faults and related fractures of large amounts of quartz with locally much pyrite, some specularite, and barite; and last, deposition of sphalerite, chalcopyrite, galena, and silverbearing tetrahedrite with a gangue of pyrite, fluorite, quartz, and calcite, Evidence of relationship between the first and second stages is suggested by more intense metamorphism where faults are large and numerous and by the common occurrence of hedenbergite in metamorphosed beds and in bands with quartz in veins. The second and third stages were more directly related than the first two, and they were separated by a period of fracturing. The rising solutions followed fault fissures, virtually all of which contain at least some quartz, and also spread out from the fissures along certain horizons to form bedded or blanket deposits. The early quartz, however, is virtually confined to veins, which are particularly numerous and conspicuous in the Dakota (?) quartzite; very little, if any, was deposited along beds. The quartz veins invariably pinch out on passing from quartzite into shale (hornfels). The workable shoots of sulphide occur in veins and in replacement bodies along beds. Blanket deposits `are characteristic of the four mines that produced most of the ore.

Zoning is suggested, with copper-silver deposits centering on Treasure Mountain and North Pole Basin and with lead-zinc and silver deposits occurring to the northwest and southeast. For future prospecting the bedded or blanket types of deposits are recommended rather than the conspicuous quartz veins, which seem to have been preferred by the prospector. Veins are promising only where they intersect limy beds known to be favorable for ore.

Marble was recognized as early as 1880 , but substantial development and production did not begin until 1908 or 1909 , after the railroad was built to Redstone for developing coal deposits on Coal Creek. The marble quarry is near Marble, 13 miles from Redstone, and is in recrystallized Leadville (Mississippian) limestone. This formation is uniformly recrystallized to a white marble throughout its extent along the Crystal River and Yule Creek. Local development of metamorphic minerals, distribution of bands of chert and dolomite, and location are factors that control the possible commercial value of a particular outcrop. An abundant reserve of marketable material is indicated. . Quarrying is complicated by the presence of joints, chert bands, and irregular masses of dolomite. These features are so closely related to the grain of the marble that quarrying of rectangular blocks is difficult and attended by a large percentage of waste. Nevertheless the quarry is noted for its ability to furnisb blocks of large dimensions.

The marble is sold for exterior and interior building and for statuary and decorative use. Much of the marble is finished in the mill at Marble, and considerable unfinished marble, particularly statuary and decorative stock, is shipped. The bulk of the marble goes to western markets, but some is sent to eastern markets. The quarry and mill are owned and operated by the Vermont Marble Co., of Proctor, Vt. 


\section{INTRODUCTION}

\section{LOCATION AND ACCESS}

The Snowmass Mountain area, comprising about 64 square miles, has an irregular outline and, as shown in figure 1 , lies between meridians $107^{\circ}$ and $107^{\circ} 10^{\prime}$ west longitude and parallels $39^{\circ}$ and $39^{\circ} 7^{\prime} 30^{\prime \prime}$ north latitude. The Aspen quadrangle joins the area on the east and the Anthracite quadrangle on the south, but to the west and north the topography is not mapped. The town of Marble, at the western edge of the area, is connected with Glenwood Springs by highway and railroad and is thus easily accessible from the north. From Crested Butte, the nearest railroad station to the south, a

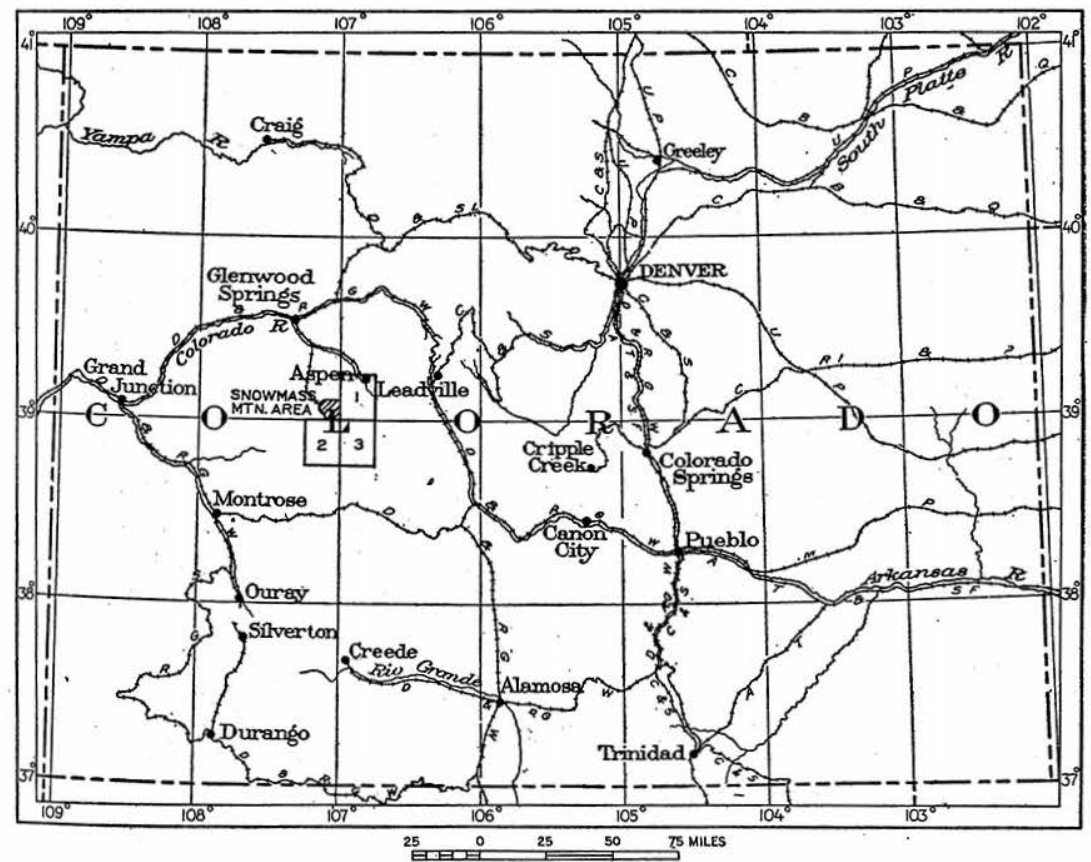

FIGURE 1.-Index map showing location of Snowmass Mountain area. 1, Aspen quadrangle ; 2 , Anthracite quadrangle; 3 , Crested Butte quadrangle.

road leads over Schofield Pass into the southeastern part of the area, but the old wagon road that formerly connected the northwestern and southeastern parts of the area has deteriorated to a trail that is passable with difficulty for horses.

\section{PHYSICAL FEATURES}

The Snowmass Mountain area includes a part of the Elk Mountains, a relatively small but nevertheless a very prominent range in the Southern Rocky Mountain province. The geomorphic forms 
are only in part controlled by the structure and relative resistance of the rocks to erosion. Snowmass Mountain is composed of granodiorite, and Maroon Peak of flat-lying sedimentary rocks, but both are about equally rugged and both reach altitudes of more than 14,000 feet. The divides are narrow, and most of them are more than 12,000 feet in altitude, but a few are less than 11,000 feet. The principal valley is that of the Crystal River, which lies at an altitude of 9,000 feet in the central part of the area and 1,000 feet lower at Marble, at the western margin. The gorges are the result of severe glaciation and are as imposing as the peaks and serrated ridges; they usually head in cirques with large accumulations of talus from the oversteepened cliffs. Locally the gorges broaden to form relatively wide and attractive valleys or parks, such as Schofield Park and Lead King Basin. The Crystal River, which is tributary to the Roaring Fork of the Colorado River system, flows west and north and drains all the area except two small partsan area to the northeast that is drained by Snowmass Creek, which flows north to Roaring Fork, and an area to the southeast that is drained by the East River, which flows south to the Slate River.

A view from any high peak includes several flat-topped hills. These flat surfaces are composed of quartzite, shale, and other sedimentary rocks, as well as Tertiary igneous rocks, and apparently are remnants of former erosion surfaces. Glacial boulders occur 1,000 to 1,500 feet above the floor of the valley of the Crystal River fully 12 miles northwest of Marble. A regional study of geomorphic forms would doubtless reveal a long history of erosion. Postglacial streams have cut narrow $\mathbf{V}$-shaped canyons, some of which are as much as 200 feet deep and 200 feet wide, in the resistant Dakota (?) quartzite. These striking canyons represent marked erosion, but they are insignificant as compared with the valleys, rock terraces, and other forms carved by glaciers.

\section{CLIMIATE AND VEGETATION}

The climate of the Snowmass Mountain area is subject to the wide range of temperature and precipitation common in mountainous districts of high altitude. Much snow accumulates during the long winter, and there is considerable rain during the summer. On south slopes and on most untimbered slopes even at high altitudes and in the lower valleys the snow is usually melted by late May, whereas at high altitudes on north slopes and on those protected by timber the snow remains until late June. Small permanent ice banks are found at the head of Bear Basin and also a short distance southeast of the Yule-Slate Creek Pass. Snowslides are common and are especially frequent in the Crystal River canyon between Marble and Crystal, where slides come from the high steep slopes 
of Treasure Mountain. ${ }^{1}$ Snowslides also occur almost yearly in the valley of East River below Emerald Lake, where they come from the northeast face of Mount Baldy. It is not uncommon for ice and snow accumulated by snowslides to block the road in these two places until middle or late July, and in some years these banks of ice remain throughout the summer.

May and June, the spring season, have many warm sunshiny days, but the nights remain cold. A rainy season usually begins early in July and continues well into August. During this season the rainfall at times becomes general, but more often it consists of local thunder showers, which center over the higher peaks. A little snow falls and melts immediately on the higher peaks through the summer, but late in August snow becomes more common than rain, and in September snow is expected at altitudes as low as that of Marble. The period October to April is generally considered the winter season. There are, however, many delightfully warm clear sunny days until well into December, and most of the winter precipitation comes after that month. Weather records are not available, and the range of temperature is not known, but $20^{\circ}$ to $30^{\circ}$ below zero is probably not uncommon, as these temperatures are recorded in neighboring areas. During the summer $70^{\circ}$ to $80^{\circ}$ is considered warm, and at Marble $85^{\circ}$ is regarded as unusual.

Many of the slopes are covered with spruce and fir as high as 11,600 feet in altitude. The thickest growth is always on north slopes, and it continues to slightly higher altitudes there than on the slopes facing in other directions. Thick groves of quaking aspen grow in the valley of the Crystal River from Crystal to a point several miles downstream from Marble. The growths of aspen are particularly luxuriant in Mancos shale soil on slopes below 10,000 feet. During the rainy season the open grassy slopes are tinted yellow, red, or blue, or combinations of these colors, by flowering vegetation. Relatively large areas of smooth grassy slopes at and above timber line, which ranges from 11,500 to 11,700 feet, afford excellent grazing for sheep.

\section{PREVIOUS WORK}

Evidence of mineralization was recognized in this region at least as early as 1875. Holmes, ${ }^{2}$ of the Hayden Survey, mapped this area and in his report referred to the "lead-silver mineralization" on Treasure Mountain. He recognized the intrusions of Treasure Mountain and Snowmass Mountain, but naturally his report does not include detailed

\footnotetext{
${ }^{2}$ Treasure Mountain, a primary triangulation point, is approximately at the crest of the Treasure Mountain dome and must not be confused with Treasury Mountain, also a primary triangulation point, about 2 miles to the southwest.

2 Holmes, W. H., [Report on the geology of the northwestern portion of the Elk Range] : . \$. Geol. and Geog. Survey Terr. 8th Ann. Rept., p. 67, 1876.
} 
descriptions. The Anthracite-Crested Butte folio describes the district adjoining this area on the south and contains brief reference to the area of Snowmass Mountain; its description of the intrusive rock of the White Rock Mountains of the Sawtooth Range is in general applicable to the intrusive rock of Snowmass Mountain. A few references to mines and to attempts at mining were made in mining magazines from 1880 to 1890, and, after the development of the large deposit of marble in Yule Creek, references to the marble industry were made in several trade journals, but none of these publications contain more than brief references to geologic conditions. A preliminary report on the geology of Galena Mountain, situated in the southern part of. the area, has been published, ${ }^{3}$ and the stratigraphy of the formations found on Yule Creek has been described. ${ }^{4}$ These recent descriptions are based on the same field work as this report.

\section{FIELD WORK AND ACKNOWLEDGMENTS}

This report is based on a little over 2 months of field work in 1930 and 5 months in 1931 . Two weeks was spent in 1932 in studying that part of the Snowmass Mountain intrusion which lies north of the area included in this report and the intrusive rock of Mount Sopris, which constitutes the north end of the Elk Mountains. In 1932 several days was also used to trace the northwest continuation of the Elk Mountain fault.

In $1930 \mathrm{~J}$. B. Reeside, Jr., visited the area while studying the Triassic in western Colorado, and I wish to thank him for his help, especially in verifying the identification of the horizon of the Niobrara limestone in the Mancos shale. During the field season of 1931 B. S. Butler visited and studied the area for several days and aided materially in solving field problems. G. F. Loughlin visited the area during the field season of 1932, examined critical places, and gave particular attention to the Yule Colorado marble quarry, and I am indebted to him for his aid and advice, both in planning the field work and the report. Without his assistance the production figures of the marble quarry and the list of buildings in which the marble has been used would have been incomplete. I am also indebted to G. W. Bain, consulting geologist of the Vermont Marble Co., for supplying results of recent studies of the physical properties of the marble. It is difficult to acknowledge satisfactorily the benefits derived from discussions with colleagues of the Geological Survey and in particular those of the Golden office, as well as those not connected with the Survey. I wish to thank Dr. R. D. Crawford, of

\footnotetext{
${ }^{8}$ Vanderwilt, J. W., Preliminary geologic notes on Galena Mountain, a part of Snowmass Mountain area, Colo. : Colorado Sci. Soc. Proc., vol. 13, no. 1, pp. 3-18, 1932.

4 Vanderwilt, J. W., and Fuller, H. C., Correlation of Colorado Yule marble and other early Paleozoic formations on Yule Creek, Gunnison County, Colo.: Colorado Sci. Soc. Proc., vol. 13, no. 7, pp. 439-464, 1935.
} 


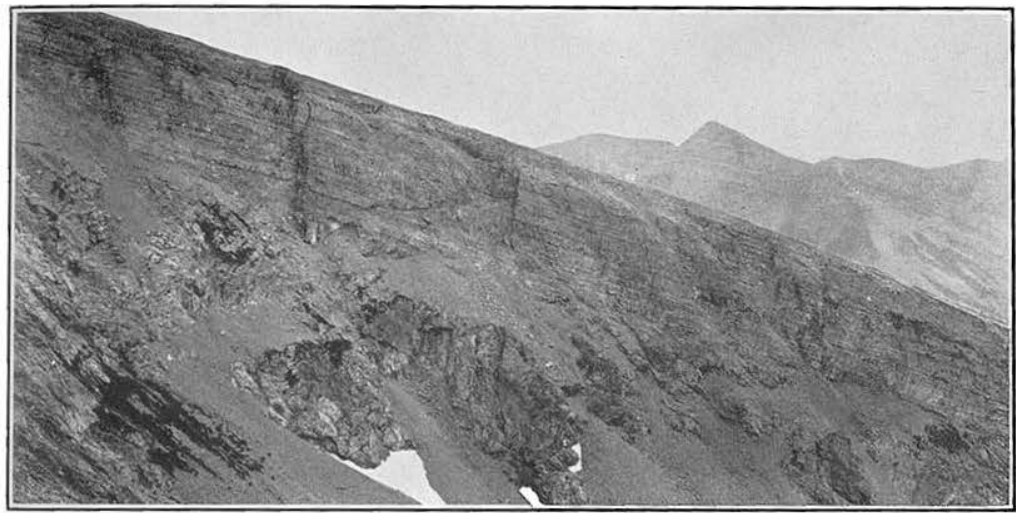

A. RIDGE OF CAMBRIAN (SAWATCH) QUARTZITE FORMING THE WALL OF A CIRQUE ON THE SOUTHWEST FLANK OF TREASURE MOUNTAIN.

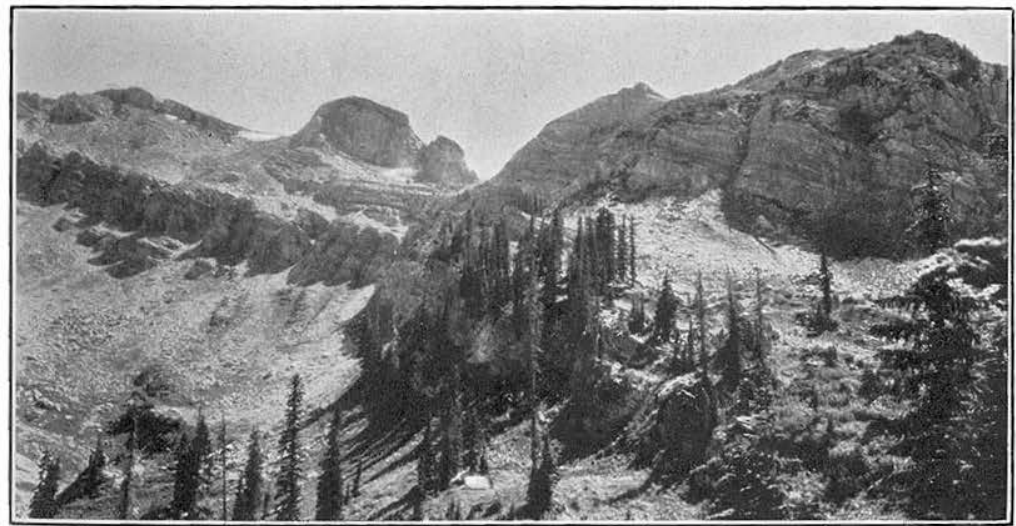

B. CHARACTERISTIC BLUFF OF ORDOVICIAN (MANITOU) DOLOMITE ON THE SLOPE SOUTHEAST OF WHITEHOUSE MOUNTAIN.

The lower continuous ledge is Manitou dolomite and the upper bluff is Mississippian (Leadville) limestone. Between these two formations lie upper beds of Ordovician and Devonian age that form less conspicuous outcrops.

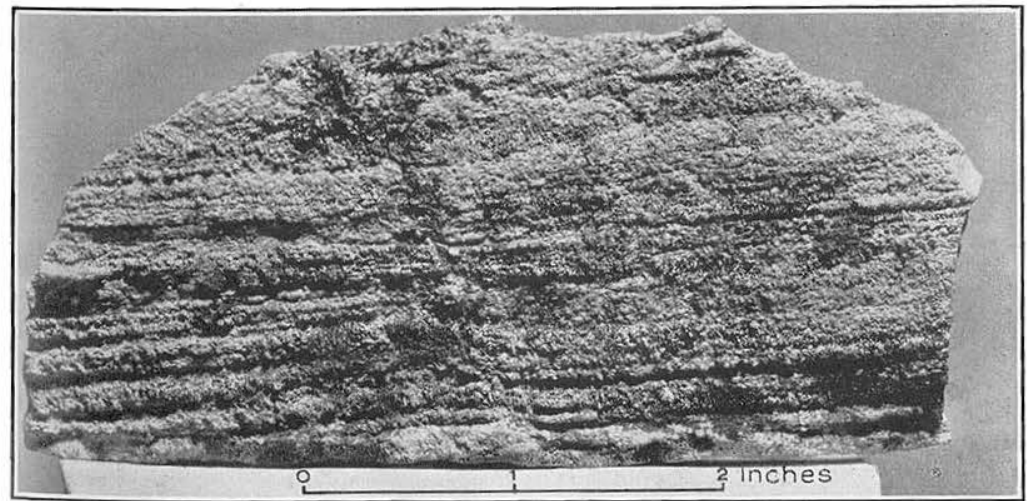

C. BANDING CHARACTERISTIC IN OUTCROPS OF WEATHERED SURFACES OF MANITOU DOLOMITE. 


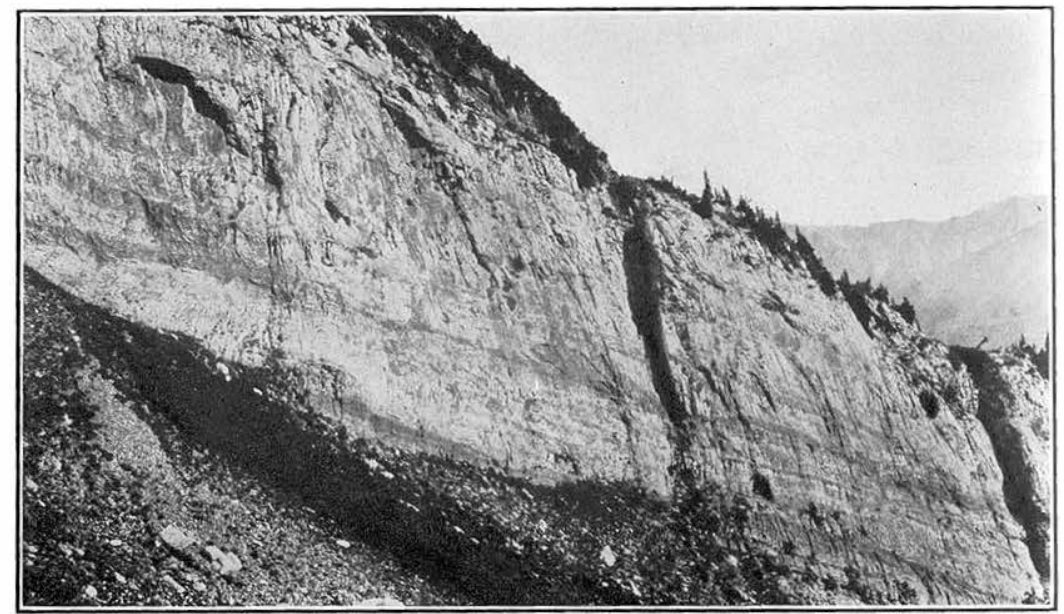

A. INTERBEDDED DOLOMITE, DOLOMITIC LIMESTONE AND LIMESTONE IN THE LOWER PART OF THE MISSISSIPPIAN (LEADVILLE) LIMESTONE ON EAST SLOPE OF WHITEHOUSE MOUNTAIN.

Total thickness about 200 feet. A little Dyer (Devonian) dolomite is exposed in the lower right corner.

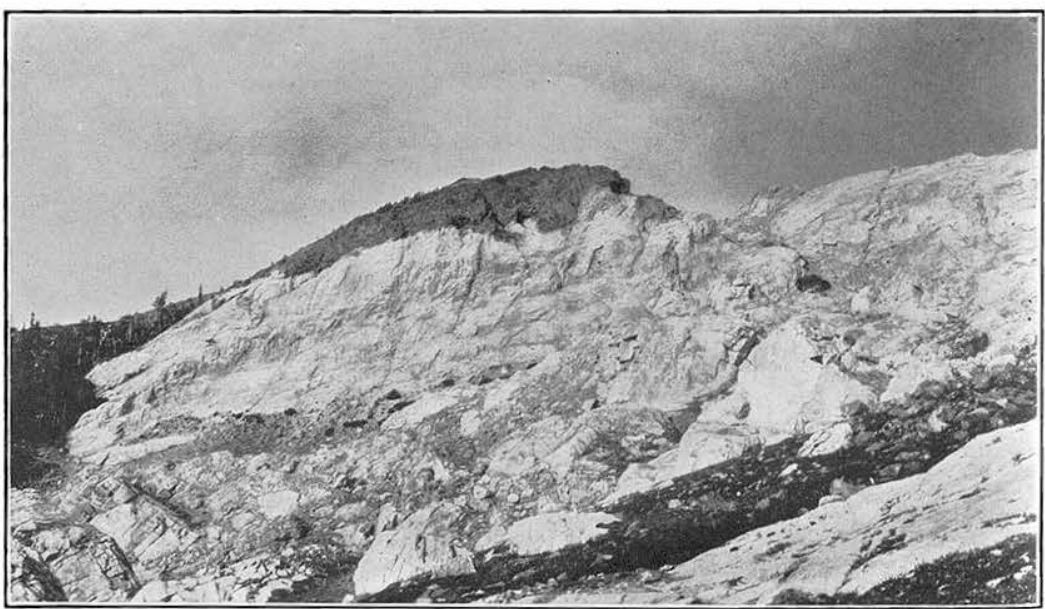

B. BEDDING BROUGHT OUT BY WEATHERING OF UPPER PART OF MISSISSIPPIAN (LEADVILLE) LIMESTONE CALCITE MARBLE SOUTHEAST OF SADDLE SOUTH OF WHITEHOUSE MOUNTAIN.

The erosion-surface contact between marble and overlying Hermosa (p) Pennsylvanian beds is also shown. 
the University of Colorado, for the opportunity to examine his collection of Tertiary igneous rocks and for his advice on several problems related to them.

Appreciation and thanks are here expressed to the residents of Marble and Crested Butte whose cooperation made field work more effective as well as more pleasant and whose information concerning old and nearly forgotten claims and mine workings was a decided help.

I was ably assisted in both geologic mapping and examination of prospects during most of each field season by H. C. Fuller.

\section{GEOLOGY}

\section{SUMMARY}

Pre-Cambrian gneiss, Paleozoic, Jurassic, and Cretaceous sedimentary rocks, and Tertiary intrusions of granodiorite and quartz monzonite crop out within the limits of the area. (See pl.1.) Tertiary sedimentary formations are not present.

The important structural features of the area are (1) the Elk Mountain fault, which extends northwestward across the area and along which Permian on the east moved, by reverse faulting, against. overturned Cretaceous (Dakota? and Mancos) and Jurassic (Entrada sandstone and Morrison formation) on the west; (2) the Snowmass Mountain stock of granodiorite along the Elk Mountain fault, intrusive into the Maroon beds; (3) the Treasure Mountain dome, formed by the intrusion of Tertiary granite; and (4) an angular unconformity at the base of the Jurassic, representing the elimination of 5,000 to 8,000 feet of Paleozoic and Mesozoic sedimentary beds. Outside the Snowmass Mountain area some of these features: are to be found in neighboring scattered localities, but all of them are not known to be concentrated in a small area.

\section{PRE-CAMBRIAN GNEISS}

Distribution.-Pre-Cambrian gneiss is exposed only on the north and south flanks of Treasure Mountain up to an altitude of about 13,000 feet. It does not extend down to the bottom of the valley of the Crystal River on the north side but it extends down to Yule Creek on the south side and continues along it. The nearest pre-Cambrian outcrops in other areas are 18 to 20 miles to the east, where they form the western flank of the Sawatch Range east and southeast of Aspen. In these areas and in general on the Sawatch Range the gneiss is similar to that found on Treasure Mountain.

General features.-The gneiss is a medium-grained gray rock in which biotite, feldspar, and quartz predominate. Just below and east of the crest of Treasure Mountain the gneiss is locally stained 
conspicuous bright reds and yellows owing to slight alteration of the biotite. Elsewhere the rock is unaltered and has dark-colored outcrops. A few small pegmatite dikes were observed in the valley of Yule Creek. Irregular masses of pegmatite are more abundant than the dikes, but they are invariably small, and nowhere were they estimated to constitute more than 5 or 10 percent of the rock.

The laminated and banded structure typical of gneiss is well developed, but it is highly contorted and without marked parallelism except that the bands dip generally $60^{\circ}$ to $75^{\circ}$ or more. On the south flank of Treasure Mountain, near the group of lakes, strikes of N. $40^{\circ}-60^{\circ}$ W. and dips of about $75^{\circ}$ NE. predominate. Similarly northwest strikes also appear to predominate in the valley. As this strike is approximately parallel to the axis of the dome it would not be affected much by the uplift, but the dip, which is now $60^{\circ}-75^{\circ} \mathrm{NE}$., would have been essentially vertical before the uplift. In addition to being contorted the bands and laminae are not uniformly spaced. In places over small areas the rock is massive and more like granite than gneiss.

Under the microscope the gneiss shows quartz, orthoclase, plagioclase, biotite, muscovite, some microcline, and small amounts of chlorite, apatite, titanite, and magnetite. The quartz and orthoclase appear in their normal habits. The plagioclase is only locally present and was identified as oligoclase $\left(\mathrm{Ab}_{85} \mathrm{An}_{15}\right)$. The biotite is usually brown, but green biotite is also present, and both colors in a single grain are not uncommon. Some of the biotite is very pale brown and appears to grade into colorless mica or muscovite. Like the biotite the muscovite occurs in bands, both alone and with biotite. Chlorite replaces biotite.

In thin section the gneiss just below the Cambrian quartzite below the Skyline mine does not show evidence of granulation or any undulatory extinction of either feldspar or quartz; however, a specimen collected near the crest of the dome from the iron-stained gneiss mentioned in an earlier paragraph shows evidence of deformation. There the orthoclase and to some extent the quartz show granulation, and the larger grains have very strong wavy extinction. This relation suggests greater strain near the crest than on the flank of the dome, but further study is necessary because the observations made were too few to warrant a conclusive interpretation of the differences noted.

\section{PAIEOZOIC SEDIMENTARY ROCKS}

\section{REGIONAL SETTING}

The Paleozoic sedimentary rocks, ranging in age from Cambrian to Permian, are exposed in many places in central Colorado in a zone with a northwesterly trend. This zone includes the northern 
part of the Sangre de Cristo Mountains to the southeast and the Sawatch Range and the White River Plateau to the northwest. The Snowmass Mountain area is situated on the extreme western margin of this belt, opposite the Sawatch Range. In this zone over large areas the stratigraphy is characteristic and in general similar. The most pronounced variations in lithology occur in the Pennsylvanian and Permian rocks. The pre-Pennsylvanian rocks are not only more uniform in development but they also include the most productive ore-bearing belts in the Leadville and Aspen areas and in consequence have been studied in greater detail than the younger members of the Paleozoic. The extent of the Paleozoic rocks to the west is unknown: for many miles only Jurassic and younger formations are exposed, and these beds rest directly on pre-Cambrian granite and gneiss over large areas to the south and southwest as far as the San Juan Mountains, where Paleozoic formations are well developed and exposed.

The nearest neighboring areas in which the Paleozoic formations of the region are exposed and have been described are (1) Cement Creek; in the Crested Butte quadrangle, to the southeast, described by Eldridge, ${ }^{5}$ and (2) the Aspen district, to the east, described by Spurr. $^{6}$. An excellent section of Paleozoic formations is found at Glenwood Springs, and in this area the pre-Pennsylvanian rocks have been described by Kindle, ${ }^{7}$ who, however, does not include the Pennsylvanian or Permian rocks in his discussion. Recently the prePennsylvanian sections of Cement Creek and Glenwood Springs were described by Vanderwilt and Fuller. ${ }^{8}$

\section{METAMORPHISM}

By the metamorphic action of the granite several of the familiar lithologic features of the sedimentary rocks on the Treasure Mountain dome have been obliterated, and certain unfamiliar features, which occur in their stead, are confusing unless the observer is familiar with the local effects of metamorphism. Limestones of the Leadville and Hermosa (?) formations have been recrystallized to white marble, of which the Yule Colorado marble is of commercial importance. Silicates, such as serpentine, diopside, actinolite, and andradite, have developed in abundance, especially in dolomite and in siliceous beds. Shale, particularly in the Hermosa (?) formation,

\footnotetext{
Eldridge, G. H., Geol. Survey Geol. Atlas, Anthracite-Crested Butte folio (no. 9), p. 6, 1894.

${ }^{B}$ Spurr, J. E., Geology of the Aspen mining district, Colo.: Geol. Survey Mon. 31, pp. $1-33,1898$.

${ }^{7}$ Kindle, E. M., The Devonian fauna of the Ouray limestone: Geol. Survey Bull. 391, p. 9,1909 .

${ }^{8}$ Vanderwilt, J. W., and Fuller, H. C., Correlation of Colorado Yule marble and other early Paleozoic formations in Yule Creek, Gunnison County, Colo.: Colorado Sci. Soc. Proc., vol. 13, no. 7, pp. 439-464, 1935.
} 
has been changed to hornfels, which forms steep cliffs instead of the usual covered slopes. The conspicuous and striking red color of the Maroon rocks has been altered to a drab gray. These changes are marked in their effect on the character and appearance of the outcrops of some of the sedimentary formations. The fundamental character of the section, however, has remained unchanged, and original composition can be inferred readily from the alteration products. All that is really lost comprises the original color, the texture, chiefly of the calcareous rocks, and the soft character of shale.

The sequence and important stratigraphic features that are to be described are summarized in the following table:

Paleozoic sedimentary rocks of the Snowmass Mountain area

\begin{tabular}{|c|c|c|c|c|}
\hline$\therefore$ & & Formation & $\begin{array}{l}\text { Thickness } \\
\text { (feet) }\end{array}$ & Character \\
\hline $\begin{array}{l}\text { Permian and } \\
\text { P.ennsylva- } \\
\text { nian (?) }\end{array}$ & \multicolumn{2}{|c|}{$\begin{array}{c}\text { Maroon formation. } \\
\text {. }\end{array}$} & $2,200-2,700$ & $\begin{array}{l}\text { A series of sandstone, shale, feld- } \\
\text { spgathic sandstone, and feldspathic } \\
\text { grit,which is usually conglomeratic. } \\
\text { The grit occurs in the upper part, } \\
\text { and sandstone with shale in the } \\
\text { lower part. Thin and slightly fos- } \\
\text { siliferous beds of limestone occur } \\
\text { at irregular intervals. The forma- } \\
\text { tion is red in the eastern part of the } \\
\text { area where unaltered, and, owing } \\
\text { to metamorphism, gray on and } \\
\text { around Treasure Mountain. }\end{array}$ \\
\hline $\begin{array}{l}\text { Pennsylvanian. } \\
\text { Unconformity }\end{array}$ & \multicolumn{2}{|c|}{ Hermosa (?) formation. } & $1,228-1,316$ & $\begin{array}{l}\text { Gray hornfels, quartzite, and partly } \\
\text { marbleized limestone. A few beds } \\
\text { are fossiliferous. A characteristic } \\
\text { conglomerate 5 to } 20 \text { feet thick } \\
\text { occurs at the base. }\end{array}$ \\
\hline Mississippian. & \multicolumn{2}{|c|}{ Leadville limestone. } & $170-274$ & $\begin{array}{l}\text { White medium-grained calcite mar- } \\
\text { ble, which is usually massive. } \\
\text { Chert is common in the upper part, } \\
\text { and there is some dolomite in the } \\
\text { lower part. }\end{array}$ \\
\hline \multirow{2}{*}{$\begin{array}{l}\text { Unconformity- } \\
\text { Devonian. } \\
\text { Unconformity }\end{array}$} & \multirow{2}{*}{ 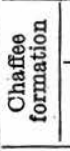 } & Dyer dolomite member. & $72-97$ & $\begin{array}{l}\text { Gray and fine-grained dolomite } \\
\text { marble. Well bedded. }\end{array}$ \\
\hline & & Parting member. & 54 & $\begin{array}{l}\text { Calcite and dolomite marble, with } \\
\text { interbedded shale and quartzite. } \\
\text { Variable along the strike. }\end{array}$ \\
\hline \multirow{3}{*}{ Ordovician. } & \multicolumn{2}{|c|}{ Fremont limestone. } & $60-63$ & $\begin{array}{l}\text { White medium-grained massive cal- } \\
\text { cite marble. }\end{array}$ \\
\hline & \multicolumn{2}{|c|}{ Harding quartzite. } & $4-5$ & Fine-grained gray quartzite. \\
\hline & \multicolumn{2}{|c|}{ Manitou dolomite. } & $81-151$ & $\begin{array}{l}\text { Gray to buff dolomite marble, well } \\
\text { bedded, with some chert locally } \\
\text { in upper part; usually contains } \\
\text { much serpentine. }\end{array}$ \\
\hline $\begin{array}{l}\text { Unconformity- } \\
\text { Cambrian. } \\
\text { Unconformity- }\end{array}$ & \multicolumn{2}{|c|}{ Sawatch quartzite. } & $219-278$ & $\begin{array}{l}\text { Gray fine-grained quartzite, usually } \\
\text { well bedded. Upper part contains } \\
\text { inter-bedded shale and limestone. }\end{array}$ \\
\hline & & & & \\
\hline
\end{tabular}

Total thickness 4,088-4,938 feet.

CAMBRIAN (SAWATCH QUARTZITE)

Distribution.-All the exposures of the Paleozoic formations except the Maroon are confined to the flanks of the Treasure Mountain dome. The general distribution of these formations is therefore 
very much the same. Cambrian (Sawatch quartzite) lies in a narrow. continuous band along the crest of the dome. Along the valley of the Crystal River the Cambrian beds have been cut out by the granite of the intrusion that formed the Treasure Mountain dome. In the vicinity of Twin Bridges the quartzite is found within a few hundred feet of the bottom of the valley, and in Bear Basin, to the :southeast, the outcrops are nearly 3,000 feet above the valley. On the southwest side of Treasure Mountain the formation has a continuous oval outcrop from the crest of the mountain into and across Yule Creek near its head, paralleling the stream down the valley first on the south and then on the north side for 5 or 6 miles before swinging back up the slope toward the crest. For 3 or 4 miles along Yule Creek upper beds of the formation are cut out by an angular unconformity at the base of the Jurassic.

The lower part of the Cambrian is a thick quartzite member that forms prominent cliffs and bluffs, but the upper part has poor outcrops because of the shaly beds and thin-bedded limestone it contains. The Cambrian is normally overlain by a thick cliff-forming dolomite of Ordovician age. The steep bluff above the covered slope of the upper part of the Cambrian is an easily recognized topographic feature.

Lithologic character and thickness.-The best sections are found at the head of Yule Creek and on Treasure Mountain below the Skyline mine, southeast of Whitehouse Mountain. The two localities are only about 5 miles apart, and the general lithology of the formation is the same, but thicknesses differ slightly.

The measurements obtained of this formation are as follows:

Section of Cambrian quartaite at head of Yule Creek and on Treasure Mountain

2. Quartzite, limestone, dolomitic limestone, and shales Feet interbedded, gray and thin-bedded. Quartzite is predominant at head of Yule Creek and dolomite on Treasure Mountain. Yule Creek, 91 feet; Treasure Mountain, 90 feet

$90-91$

1. Quartzite, gray and fine-grained. Well bedded with strata 6 inches to 4 feet thick. A few calcareous zones in which the rock is a quartzitic sandstone. Yule Creek, 187 feet; Treasure Mountain, 128 feet_ 128-187

The lower member (1) is uniformly fine-grained except for a basal conglomerate observed locally due east of the summit of Treasure Mountain. The conglomerate is only a few feet thick and consists of well-rounded quartz pebbles 1 inch or less across in a matrix of fine quartz sand. The calcareous beds are in reality sandstones with some calcite as matrix; they occur at irregular intervals and range from a few inches to 10 feet in thickness. They are as 
a rule not numerous and can be distinguished in outcrop from the more resistant quartzite by their greater tendency to disintegrate. A typical cliff of the lower member of the Cambrian quartzite with its characteristic bedding is shown in plate $2, A$. The bedding surfaces are well developed but are so uneven that strikes and dips are usually difficult to obtain from small exposures.

The upper member (2) is not well exposed except on very steep and virtually inaccessible slopes. On Treasure Mountain it is generally marked by a zone covered with tabular fragments as much as 2 inches thick of quartzite, sandy dolomite, hornfels, and marble. At the head of Yule Creek the individual beds of quartzite, impure limestone, dolomite, and shale (hornfels) are thicker than on Treasure Mountain. Some of the purer quartzites of this upper member (2) are similar in color and texture to the quartzite of the lower member (1), but the thickness of a bed or aggregate thickness of several successive beds of purer quartzite in the upper member is rarely as much as 5 feet, whereas in most places the lower member is essentially pure quartzite.

The lithology of the quartzite of the Cambrian is typical and is best developed in the lower half or two-thirds of the formation. The upper part of the Cambrian is generally a highly siliceous member ranging from a shaly to a dolomitic zone which everywhere contains interbedded quartzites lithologically like the quartzite below. The upper boundary of the Cambrian is well defined by the marked lithologic change from siliceous beds below to dolomite above. Locally some of the thin dolomites of the upper part of the Cambrian are similar to the overlying Ordovician dolomite, and in places the boundary between the two cannot be definitely placed in a zone that is usually less than 15 feet thick.

\section{ORDOVICIAN}

Distribution.-The Ordovician beds of this area consist of a thick marbleized dolomite overlain by quartzite and white calcite marble. The band of the Ordovician parallels the Cambrian beds, but it is not continuous along the crest of the Treasure Mountain dome. Only remnants of the basal dolomite (Manitou) are present here, and all the Ordovician is cut out for 3 or 4 miles along Yule Creek by the erosion that produced the angular unconformity at the base of the Jurassic. The Manitou formation is also found high on the dome both at the northwest end toward Whitehouse Mountain and at the southeast end near Treasury Mountain. Conspicuous bluffs mark the outcrop of the formation (pl. 2, B). The lower parts stand out markedly above the covered slopes produced by the weak upper member of the Cambrian. The upper 60 feet of the Ordovician formation usually crops out in a prominent ledge which is conspicuous 
because of the whiteness of the marbleized Fremont limestone, and because the overlying Parting member of the Chaffee formation (Devonian) forms covered slopes. (See pl. 2, B.)

Lithologic character and thickness.-A complete section of the Ordovician is exposed along Yule Creek above the Yule Colorado marble quarry, and although the general character of the formation is well brought out, the exposures are not good for detailed measurements. The best exposed sections of the Ordovician as well as of the Cambrian were found at the head of Yule Creek and high above the Crystal River on the flank of Treasure Mountain southeast of Whitehouse Mountain. The measurements obtained are:

\section{Section of Ordovician at head of Yule Creek and on Treasure Mountain Ordovician : \\ Fremont limestone: \\ Feet}

5. Limestone marble, white, medium-grained, and massive; 6 to 10 feet of dark-gray marble at base. Yule Creek, 63 feet; Treasure Mountain, 60 feet_.

Harding quartzite:

4. Quartzite, gray and fine-grained; dolomitic and shaly in places. Yule Creek, 4 feet; Treasure Mountain, 5 feet.

Manitou dolomite:

3. Dolomite marble, gray to bluff. Bedding well developed and individual beds generally less than 12 inches thick. In places chert is found in upper 10 feet. Much serpentine is present and develops a characteristic banding or ribbing on exposures across bedding. Yule Creek, 81 feet; Treasure Mountain, 151 feet

The Manitou dolomite (3), except for its thickness, is uniform throughout the area. The rock is recrystallized and contains abundant green and black serpentine and some yellow serpentine as well as diopside developed in irregular stringers parallel to the bedding. The serpentine is everywhere most abundant in the lower part of the dolomite. The numerous parallel stringers of serpentine produce on weathered surfaces perpendicular to the bedding a grooved and ribbed pattern and a conspicuously thin-banded rock (pl. 2, C), not found in other beds, which serve to identify this formation. It could not be determined to what extent this banding has been controlled by or expresses the original bedding of the rock. The grooves are 2 to 3 millimeters deep and are oriented nearly parallel to the bedding. On Treasure Mountain serpentine is abundant only in the lower beds, and diopside is predominant in the upper part, although it is inconspicuous owing to its white color. At the head of Yule Creek serpentine is abundant throughout the 
formation. In places the lower 15 to 20 feet is sandy and contains a few sandstone beds as much as 2 inches thick, and in the upper 20 to 30 feet chert nodules, irregular in form and distribution, are locally developed along the bedding. The remainder of the formation does not show quartz sand or chert, but an original siliceous content can be inferred from the presence of the serpentine.

The Harding quartzite (4) is very inconspicuous in outcrops but is apparently continuous throughout the area. The grain is slightly finer than in the Cambrian quartzite. The sediments apparently contained impurities, like clay and iron, as the rock usually contains a little pyrite and also enough serpentine to give the quartzite greenish tints. Locally the rock is more nearly hornfels than quartzite. The Fremont limestone (5), above the Harding, is a white medium-grained marble very similar to the Yule Colorado marble (Mississippian) and like it forms ledges that stand out in contrast to the darker beds that lie immediately above and below it. The Fremont marble, however, is only 60 feet thick and in outcrop need not be confused with the Yule Colorado marble, which is fully three times as thick.

\section{DEVONIAN (CHAFFEE FORMATION)}

Distribution.-The Devonian Chaffee formation consists of two members, neither of which forms prominent or conspicuous outcrops. The lower member, 50 to 60 feet thick, is made up of thinbedded shales (hornfels), marbleized dolomite, and quartzite and usually forms covered slopes. The upper member is dolomite, which forms the base of the more prominent cliffs of the overlying Mississippian (Leadville) limestone. In localities where both Ordovician and Mississippian formations are well exposed the Devonian can be recognized between the two. (See pl. 2, B.)

The outcrops of Devonian beds parallel those of the Ordovician. They are found high on the Treasure Mountain dome, at the northwest end toward Whitehouse Mountain and at the southeast end on the west slope of Treasury Mountain. The Devonian has been removed by erosion from the southwest and northeast flanks of the dome. On Yule Creek it is absent for 3 or 4 miles along the angular unconformity at the base of the Jurassic, and in the valley of the Crystal River it is cut out by the Tertiary granite.

Lithologic character, subdivisions, and thickness.-The upper part of the Dyer dolomite member is well exposed along Yule Creek just above the Yule Colorado Marble Co.'s quarry. The upper boundary occurs in the stream directly below the quarry. The Parting: member is fairly well exposed about three-quarters of a mile above the quarry in the channel of the stream. If the trolley is operating: from Marble to the quarry this locality is the most accessible one 
for seeing the Devonian beds. The outcrops are not continuous, however, and the thickness cannot be satisfactorily measured. At the head of Yule Creek and on Treasure Mountain the following measurements were obtained:

\section{Section of Devonian at head of Yule Creek and on Treasure Mountain}

\section{Devonian :}

Chaffee formation:

Dyer dolomite member:

Feet

11. Dolomite marble, light gray weathering to pale buff, fine-grained and well-bedded strata a few inches to 5 feet thick. Lower 20 feet appears to be more calcareous than dolomitic. Yule Creek, 97 feet; Treasure Mountain, 72 feet

Parting member:

10. Quartzite, gray, fine-grained. Pyrite along joints

9. Limestone marble, white, fine-grained, massive; 10 -inch shale band near middle

8. Shale, dolomitic, black, dense. In places weathered surfaces are distinctly. greenish

7. Limestone marble, dolomitic, light gray to white, fine-grained, in beds 1 to 4 feet thick, with a persistent sandy shale near middle

6. Shale and limestone, interbedded, gray. The shale is altered to brown, green, and gray. Outcrops poor

The rocks identified as the Parting member of the Chaffee formation $(6-10)$ are the only ones above the Cambrian and below the Pennsylvanian that contain an appreciable quantity of shale. In this member, which averages nearly 55 feet in thickness, there is about 36 feet of limestone and dolomite, 14 feet of shale, and 5 feet of quartzite. The quartzite occurs as a single bed at the top. Although individual beds vary along the strike, the Parting member as a whole is uniform throughout the area.

The Dyer dolomite marble (11) above the Parting member forms brown to buff cliffs. It is a little more massive than the dolomite marble (3) of the Ordovician. In places the beds are thin, but they average 2 to 5 feet in thickness. The dolomite marble appears fairly uniform from top to bottom, but the beds near the bottom effervesce more readily with acid than the beds in the upper part. The higher calcium-carbonate content which is thus indicated may have developed as a result of dedolomitization due to the formation of magnesian silicates, chiefly diopside. 
The base of the Devonian is readily fixed, as the Fremont limestone below forms prominent outcrops of massive white marble below the Parting member of interbedded limestone and shale, which forms poor outcrops. The top of the Devonian is not so evident. The marbleized buff dolomite (Dyer member) for the most part is quite unlike the white marble of the overlying Yule Colorado marble (Mississippian), but between the two are 50 to 100 feet of interbedded calcite and dolomite marble.

In this report the top of the Devonian has been arbitrarily placed at the bottom of the lowest bed of calcite marble, because this contact is everywhere sharp, whereas the dolomite above this horizon varies in thickness and locally appears to grade into calcite marble, so that well-defined limits are lacking.

\section{DEVONIAN-MISSISSIPPIAN BOUNDARY}

The lack of a definite boundary between the Devonian and Mississippian formations in the Snowmass Mountain area requires special comment, as two recent papers describe definite boundaries in other areas. In older geologic reports it is generally considered that the boundary is indefinite and is therefore usually not indicated. Gibson, ${ }^{9}$ in 1925, was the first to fix the top of the Devonian in the Red Cliff district tentatively at the base of a certain quartzite bed which contained breccia fragments of limestone. In 1929 Behre, ${ }^{10}$ apparently unaware of Gibson's conclusion, as he did not refer to it, used a similar quartzite-breccia bed as the base of the Mississippian in the Mosquito Range and Leadville district. In 1931 Kirk $^{11}$ stated:

The exact separation of the Devonian from the Mississippian is usually attended with difficulties, usually owing to the lack of good exposures. The boundary can always be drawn within a vertical distance of a few feet, however, and usually with precision. *** The basal 25 feet or so of the Mississippian seems invariably to carry one or more bands of limestone breccia. The lowest of these is usually near the base of the Mississippian. Often there is a sandstone at the base of the Mississippian. ${ }^{12}$

The first statement implies that the chief difficulty arises from lack of good exposures, but the words "seems", "usually", and "often" used in the second part of the quotation certainly qualify if they do not contradict the contention of the first. D. P. Rohlfing, ${ }^{13}$ who is well acquainted with the detailed geology of the Aspen district, does not find the boundary between Devonian and Mississippian easy to

\footnotetext{
- Crawford, R. D., and Gibson, Russell, Geology and ore deposits of the Red Cliff district, Colo. : Colorado Geol. Survey Bull. 30, pp. 37-38, 1925.

${ }_{10}$ Behre, C. H. Jr., Revision of structure and stratigraphy in the Mosquito Range and the Leadville district, Colo.: Colorado Sci. Soc. Proc., vol. 12, no. 3, p. 41, 1929.

11 Kirk, Edwin, The Devonian of Colorado: Am. Jour. Sci., 5th ser., vol. 22, p. 223, 1931.

12 Italicizing by J. W. v.

ss Personal communication.
} 
recognize. For practical purposes the miner at Aspen usually regards the contact at the top of the dolomite as the top of the Devonian and the true limestone as Mississippian.

In a study of this problem in the Aspen district ${ }^{14} \mathrm{I}$ have described a sandy zone present in all the sections studied, which can be correlated well with the sandy beds referred to above by Gibson and Behre. At Aspen all the Devonian below these sandy beds is dolomite, and the overlying Mississippian formation consists of an upper limestone member and a lower dolomite member, usually with interbedded limestone. Dolomite interbedded with limestone just below the Leadville limestone has been found on Cement Creek, at Glenwood Springs, and on Treasure Mountain and is therefore not a local feature. The limestones and dolomites on Treasure Mountain, because of metamorphism, are easily recognized by their color difference, calcite marble being white and dolomite marble buff. Ordinarily. however, the interbedded dolomite and limestone cannot be distinguished in the field unless acid tests are made. This fact is not generally appreciated, probably because the massive limestone is easily distinguished by inspection. At any rate the division between dolomite below and limestone above has been described as abrupt, without mention of an interval where the two are interbedded.

For the reasons given above the top of the Devonian on Treasure Mountain is placed at the base of the lowest limestone bed. The dolomites above this horizon do not contain the same kind of metamorphic minerals or as many as the Devonian dolomite below, and this suggests a difference in composition of these beds. (See pp. 2021.) The correlation is arbitrary at best and must be considered so as long as the variations in lithology and composition are not known in detail or are not clearly understood.

\section{MISSISSIPPIAN (LEADVILLE LIMESTONE)}

Distribution and character.-The Mississippian (Leadville) limestone has been metamorphosed to a massive bed of white marble whose outcrops are conspicuous because of the prominent white cliffs they usually form. (See pl. 2, B.) It has the same general distribution as the older Paleozoic beds, although good exposures of the marble are more numerous. Complete sections are exposed at the head of Yule Creek, along Yule Creek in the vicinity of the quarry of the Yule Colorado Marble Co., and at the northwest end of

\footnotetext{
${ }^{14}$ Vanderwilt, J. W., Revision of structure and stratigraphy, and its bearing on the ore deposits of the Aspen district, Pitkin County, Colo. : Econ. Geology, vol. 30, pp. 223-241, 1935.
} 
Treasure Mountain near Whitehouse Mountain. (See pl. 3, $A, B$.)

The sections measured are as follows:

Section of Mississippian Leadville limestone at head of Yule Creek and on Treasure Mountain

Mississippian:

Leadville limestone:

Feet

14. Limestone (calcite) marble, white, mediumgrained, and massive. Irregular $\mathrm{th}$ i $\mathrm{n}$ bands and nodules of chert in places, especially near top. Locally dolomite beds 1 foot thick were observed. Yule Creek, 176 feet; Treasure Mountain, 127 feet----

13. Dolomite and dolomitic limestone marble, gray
to buff, fine-grained, and massive. Yule Creek, 68 feet; Treasure Mountain, 22 feet_-

12. Limestone (calcite) marble, gray and white banded, medium-grained, and massive. Some dolomite. Yule Creek, 30 feet; Treasure Mountain, 21 feet $127-176$

$22-68$

$21-30$

$170-274$

The formation measured 166 feet in thickness at the quarry on Yule Creek and 239 feet about 2,000 feet southeast of the quarry. The range in thickness of more than 100 feet can be attributed either to the fact that the base is not definitely recognizable or to irregularities of the unconformity at the upper boundary, which is sharply and clearly defined. A lack of well-defined bedding in the marble makes it difficult to compare angular relations between it and the overlying Pennsylvanian (Hermosa?) beds or to determine how uneven the unconformity may be.

In the lower 20 to 30 feet (12) banding is rather pronounced (pl. $3, A)$. The darker bands are of about the same grain, and they appear similar except that they are dolomitic in places. The bands are irregularly spaced, 4 to 6 feet apart, 3 to 8 feet thick, and 100 to 1,000 feet in length. The relations suggest that the white marble is bleached gray dolomitic marble, but the banding may be an expression of indistinct bedding and differences in original composition. Bed 13 is largely dolomite, which weathers buff and also stands out in bands, which are clearly an expression of the bedding. The banding referred to in beds 12 and 13 is well shown on plate $3, A$, and also brought out on plate $2, B$. The dolomite marble is invariably finergrained than the calcite marble. It is slightly less dense than the dolomite of the Devonian but is otherwise so similar that the two are not easily differentiated. The dolomite included in the lower part of the Mississippian does not contain as many secondary silicates as are commonly found in the older beds of dolomite. No ser- 
pentine was observed, and diopside was found only locally, although both of these silicates are abundant in lower beds of dolomite. It could not be definitely determined whether this difference was attributable to a difference in the original composition of the dolomite or to other conditions that controlled the formation of the silicates. The influence of original composition, however, is strongly suggested by the fact that the calcite marble in the lower part of the Leadville limestone does not contain magnesian silicates, which are found in both Mississippian and Devonian dolomite.

The upper 127 to 176 feet of the Leadville limestone (14) is a single bed of medium-grained white marble. This marble is usually massive, as shown in plate $3, A$, but bedding surfaces are brought out in some places by weathering, as shown in plate $3, B$. The marble has a well-developed schistosity, called "grain" by quarrymen, parallel to the bedding. This "grain" is very evident in quarrying the marble, and in thin sections it resembles the structure characteristic of schist. Gray chert in thin lenses or discontinuous stringers and in beds as much as 2 feet thick is present locally throughout the formation, but the chert appears to be most abundant in the zone from which the Yule Colorado marble (formerly called Colorado Yule marble) has been quarried. This zone also contains chert or flint in the form of irregular nodules, some of which contain fragments of small cup corals, the only fossils found in the Paleozoic section below the Pennsylvanian beds.

This calcite marble, like that in the lower part of the formation, does not contain either serpentine or diopside. Locally, however, brown andradite garnet replaces the marble at the upper contact. At the head of Yule Creek garnet as much as 30 feet thick is found along the contact, and on the west slope of Treasury Mountain irregular patches of the garnet cross the entire formation.

\section{PENNSYLVANIAN (HERMOSA? FORMATION)}

Distribution.-A series of interbedded limestone, shale, and sandstone metamorphosed to marble, hornfels; and quartzite of Pennisylvanian age lies unconformably on the Mississippian. These beds crop out around Treasure Mountain in the form of a crescent open along Yule Creek, where they are cut out by the angular unconformity at the base of the Jurassic from a point near the head of Yule Creek down to the vicinity of the quarry of the Yule Colorado Marble Co. Complete sections are found on Whitehouse Mountain, at the northwest end of the Treasure Mountain dome, and on Treasury Mountain, at the southeast end. Between these two localities along the valley of the Crystal River some of the lower beds have been cut out by the intrusion of granite. These beds are correlated with the 
Hermosa formation of southwestern Colorado and are herein called Hermosa (?) formation. ${ }^{15}$

Lithology and detail of section.-The sections found in the area are not well suited for stratigraphic study, owing to the metamorphism of the rocks. The purer limestone, shale, and sandstone can be recognized as marble, hornfels, and quartzite. Intermediate rocks, such as calcareous or shaly sandstone and sandy shale, when indurated look alike and resemble a fine-grained quartzite. The shaly or sandy character of limestone may or may not be evident after alteration. These complications, however, are partly offset by the fact that the indurated beds form excellent and continuous exposures.

The beds definitely identified by fossils as Pennsylvanian consist of thick limestone members interbedded with only fine-grained clastic material; they are overlain by several hundred feet of finegrained sandstones and shales devoid of limestone and of fossils. These fine-grained sandstones and shales appear to grade into the undoubted Pennsylvanian below and also into the Maroon formation above. The Maroon conglomerate and sandstone strata contain only thin lenticular beds, none of which seem to be either continuous or confined to any particular part of the formation. In the absence of fossils the section is mapped on a lithologic basis. The boundary between the Hermosa (?) and Maroon formations, chosen for convenience of mapping, is the top of the highest thick limestone bed. This arbitrary boundary is not very definite, as the upper limestone beds may be lenticular or may grade into sandy or shaly beds so that given beds cannot be traced continuously for any great distance. The Hermosa (?) as mapped, therefore, is as likely to exclude certain Pennsylvanian beds as it is to include Permian beds.

Measurements were made both on Treasury Mountain and on Whitehouse Mountain, at the southeast and northwest ends of the Treasure Mountain dome, and the results are given below.

Section on north and northeast slopes of Treasury Mountain

Maroon formation.

Hermosa (?) formation:

14. Quartzite, gray, fine-grained. Some beds are shaly

13. Conglomerate, marbleized limestone, and a few quartz pebbles in a sandy limestone matrix

12. Quartzite, gray, shaly, much altered.

11. Conglomerate, marbleized limestone, and a few quartz pebbles in a sandy limestone matrix----

10. Quartzite, shaly, sandy hornfels, and a little limestone. Much altered

${ }^{15}$ Vanderwilt, J. W., Stratigraphy of Pennsylvanian Hermosa formation in Elk Mountains, Gunnison County, Colo.: Am. Assoc. Petroleum Geologists Bull., vol. 19, no. 11, pp. 1668-1677, 1935. 
Section on north and northeast slopes of Treasury Mountain-Continued

Hermosa (?) formation-Continued.

Feet

9. Conglomerate with white limestone marble pebbles 1 to 3 inches across in a light-gray limestone marble matrix

8. Hornfels, sandy, containing much specularite and epidote and some tourmaline. Possibly some pyrite and chlorite

7. Conglomerate, white limestone marble pebbles 1 to 3 inches across in a light-gray limestone marble matrix

6. Hornfels, gray to greenish gray, and shaly quartzitic sandstone. Shows much epidote, some garnet, and abundant specularite along joints-------

5. Limestone, gray to black, marbleized, with interbedded fine-grained sandstone and some shale. Some of the limestone is sandy or shaly and somewhat micaceous. Much epidote along bedding planes and joints

4. Hornfels, gray, with alternating beds of gray and white marbleized limestone. Hornfels sandy in places

3. Quartzite, dark gray, fine-grained, sandstone, and a little hornfels interbedded.

2. Limestone, white and gray, well marbleized, mostly massive, with a few thin beds in part replaced by yellow serpentine

1. Quartzite, gray green and black, hornfelsic, with much garnet and epidote. Upper half contains alternating beds of recrystallized limestone. Locally conglomeratic with angular fragments of chert and quartzite_-_-_-_-_-_-_-_-_-_-_-_--

Leadville limestone.

Section measured on east face of Whitehouse Mountain

Jurassic quartzite.

Hermosa (?) formation:

Feot

(1) Gray marbleized limestone and quartzite interbedded

(k) Conglomerate, pebbles of granite or gneiss 1 to 3 inches in diameter, chert, and red clay in a sandy matrix

(j) Hornfels, gray, sandy, grading upward into shaly and quartzitic sandstone. All sand is fine-grained. Contains (V. S. 336F) Chaetetes milleporaceus and Amplexus?

(i) Limestone, gray to white, marbleized; thinbedded, with bedding planes irregular and wavy. Some of lower beds are fossiliferous, showing cross sections of cup corals, brachiopods or pelecypods, and crinoid stems, which are very difficult to collect. Upper 20 feet is shaly 
Section measured on east face of Whitehouse Mountain-Continued

Hermosa (?) formation-Continued.

Feet

(h) Sandstone and shale like (b). Upper 30 feet grades upward into a gray marbleized limestone

(g) Conglomerate, marbleized limestone pebbles averaging 1 to 2 inches across in a matrix of medium-grained sandstone

(f) Quartzite, medium- to fine-grained, gray, 10 to 20 feet thick, interbedded with hornfels of equal thickness.

(e) Quartzite, gray, fine-grained. Beds well developed 6 inches to 4 feet thick, average 12 to 18 inches. Lower 45 feet is calcareous and shows some cross-bedding

(d) Limestone, gray, marbleized, with irregular beds of quartzite or shaly sandstone as much as 6 inches thick which constitute 15 to 25 percent of the unit. The quartzite is fine-grained and limy. Contains cup corals and other fossils (V. S. 161-0-1), 65 feet above base: Solenomya radiata, Solenomya anodontoides, Clinopistha radiata var. levis, Cardiomorpha missouriensis, Aviculipecten rectilaterarius, Pseudorthoceras knoxense; (V. S. 161-0-2), about 20 feet below top; Spirorbis

(c) Hornfels, gray, interbedded with 10 to 20 percent of limestone in lower half and 50 percent in upper half

(b) Limestone, gray, marbleized, thin-bedded; contains 5 to 10 percent of interbedded quartzite and hornfels. In the upper 40 feet sandstone and shale increase to about 50 percent of the rock

(a) Conglomerate; angular blocks 1 to 2 inches across of chert and quartzite in a dense black hornfelsic quartzite matrix

Leadville limestone.

G. H. Girty, ${ }^{16}$ who identified the fossils listed above, made the following statement concerning them:

The fauna of the siliceous shale (V. S. 161-0-1) is of a character most disadvantageous for age determination, for the fossils are none too well preserved and represent only pelecypod types, many of which can be identified even generically only upon characters that are not very trustworthy. This is more true of the fauna under consideration than of most pelecypod faunas, for it has been necessary to identify these fossils with types that are relatively little known. In spite of this fact I can hardly doubt that the age of this fauna is Pennsylvanian (possibly Pottsville). This interpretation is to some extent corroborated by the presence of the calcareous specimens (V. S. 161-0-2), especially by the one which contains so many shells of Spirorbis ${ }^{*} *^{*}$, for

16 Personal communication. 


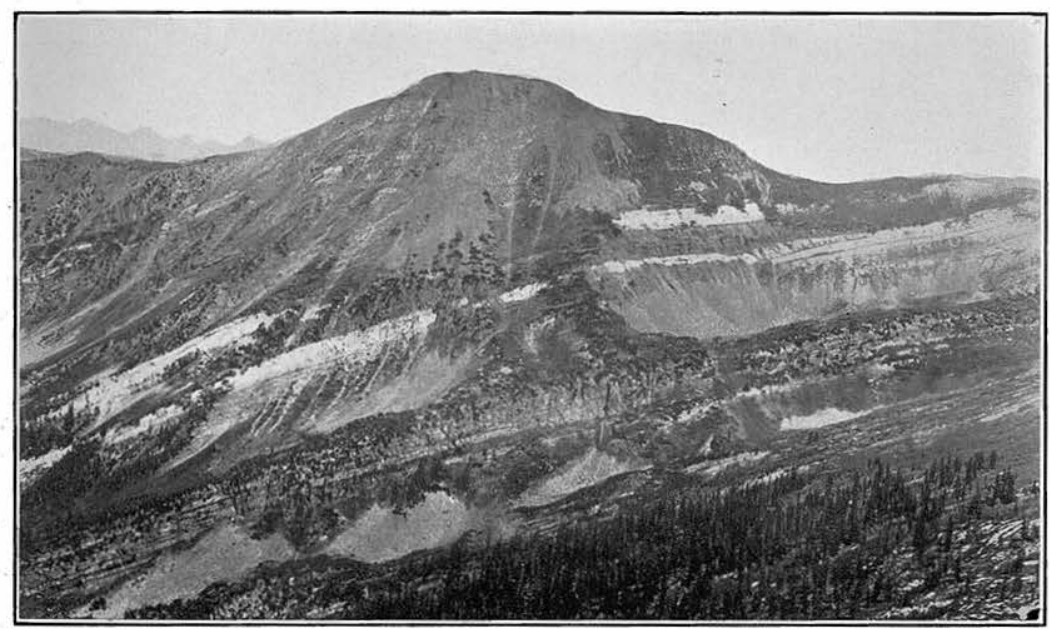

A. PROMINENT WHITE HERMOSA (?) PENNSYLVANIAN CONGLOMERATE CONSISTING OF WELL-ROUNDED LIMESTONE PEBBLES IN A LIMESTONE MATRIX, BOTH OF WHICH ARE WELL MARBLEIZED.

West slope of Crystal Peak east of Bear Basin. The conglomerate forms beds 7 and 9 of the Treasury Mountain section on p. 25.

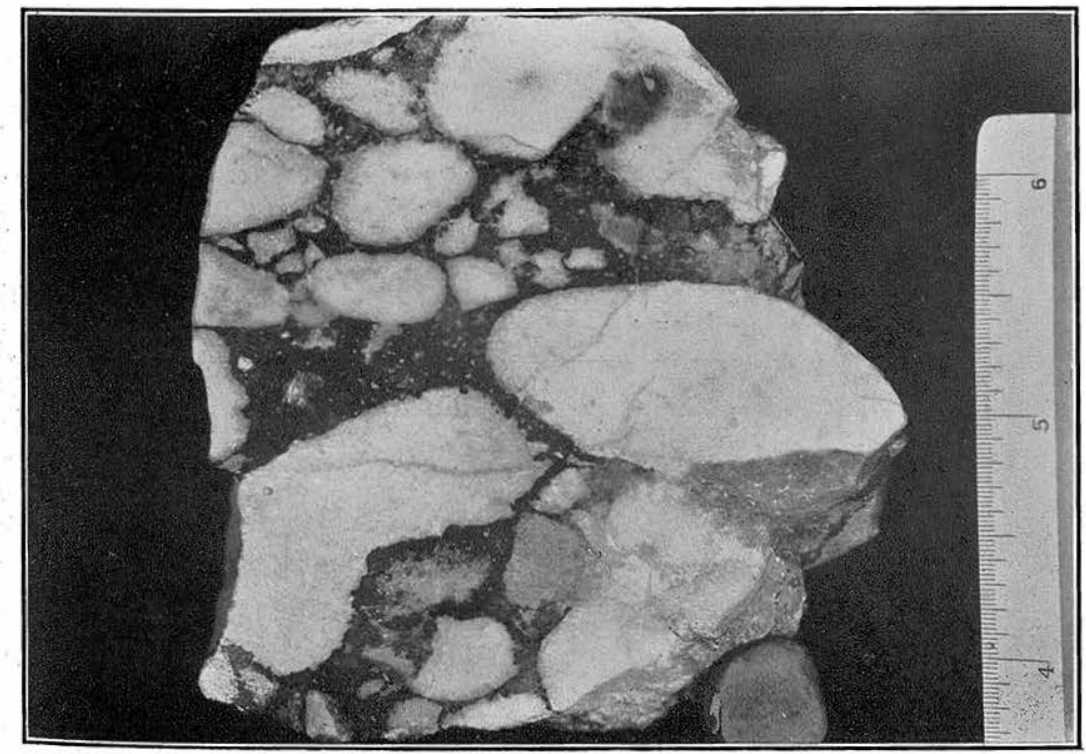

B. LIMESTONE (MARBLE) CONGLOMERATE OF THE HERMOSA (?) FORMATION SHOWN IN $A$. 


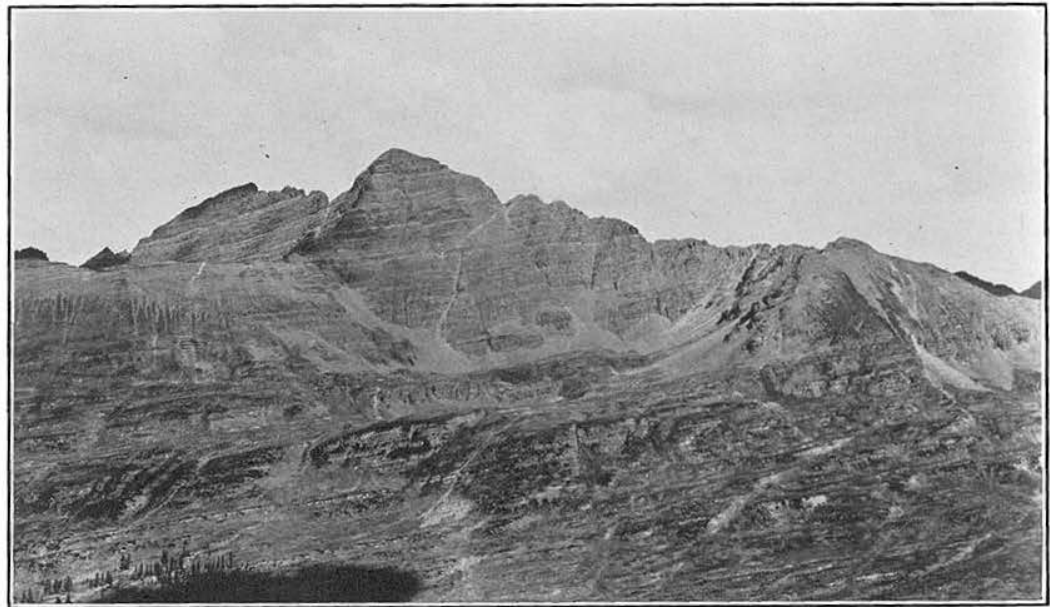

A. TYPICAL EXPOSURE OF UNMETAMORPHOSED MAROON STRATA ON EAST FACE OF MAROON PEAK.

The relative hardness of sandstone and more shaly beds is expressed by erosion features.

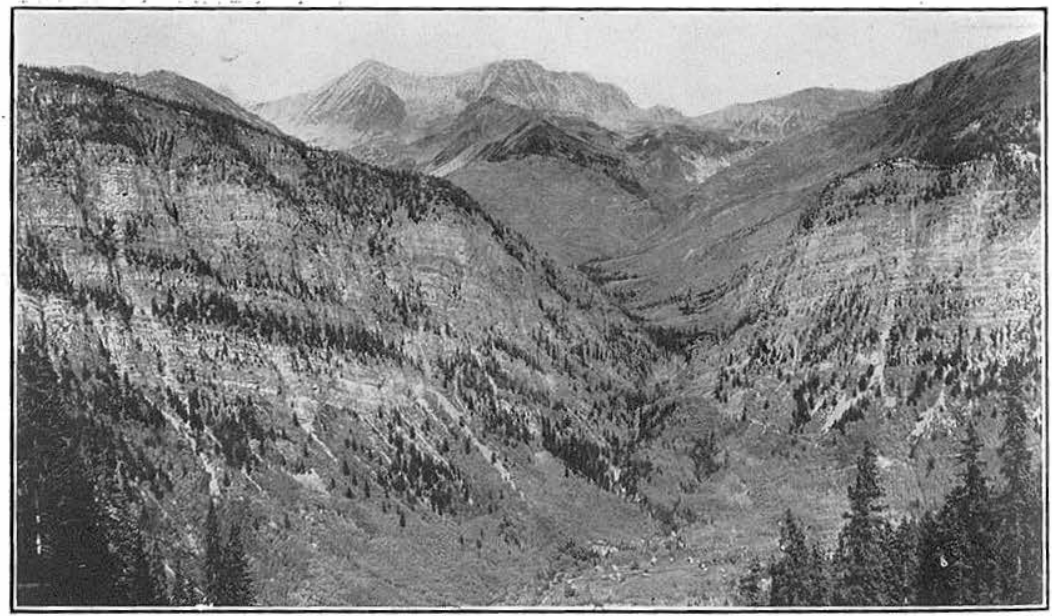

B. TYPICAL EXPOSURE OF METAMORPHOSED MAROON STRATA, LOOKING UP THE NORTH FORK OF THE CRYSTAL RIVER INTO LEAD KING BASIN.

Sheer cliffs are characteristic where shaly beds have been changed to hornfels. Cliffs at right (Mineral Point) and left (east end of Sheep Mountain) are capped by Jurassic rocks. Town of Crystal in foreground and Snowmass Mountain in background. 
although we find Spirorbis in marine faunas these minute worm tubes are especially abundant in rocks of nonmarine origin where they are associated with plant remains indicating an environmental condition that is rare if not wholly unknown in our Mississippian rocks.

Chaetetes milleporaceus is, so far as known, confined to the Pennsylvanian, and it chiefly occurs in the earlier faunas of that epoch.

These two sections are given in columnar form in figure 2, which shows the limestone beds in the section. The difference in detail of the two sections is largely attributable to lensing of beds and variation along their strike, although a minor part of the difference is also due, no doubt, to the fact that metamorphism has been more intense on Treasury Mountain than on Whitehouse Mountain, making it difficult to recognize either equivalent or similar units.

"The conglomerate at the base is consistently present throughout the area and is particularly well developed and exposed in the vicinity of the Yule Colorado marble quarry and on Whitehouse Mountain. It fills depressions 10 to 20 feet in width and depth in the top of the Mississippian (Leadville limestone), making an irregular contact, which is fairly well shown on plate $3, B$. The thickness ranges from 2 to 20 feet or more, not including a certain thickness added locally in the depressions. The: conglomerate consists of angular to subrounded fragments, some of which are 12 inches across but which average less than 3 inches, of chert and fine-grained quartzite in a fine-grained black dense matrix that was originally shale or sandy shale. A similar conglomerate was observed in mine workings in both Aspen and Smuggler Mountains, ${ }^{17}$

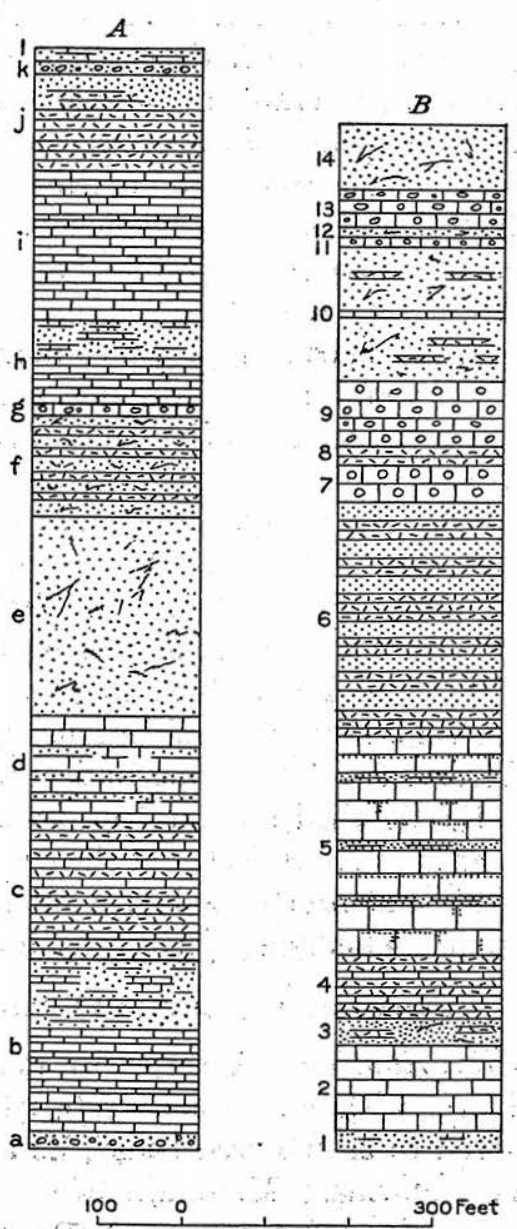

Fiádre 2.-Columnar sections of Pennsylvanian beds measured on Whitehouse Mountain (A) and on Treasury Mountain (B). The numbers and letters correspond to those used for detailed descriptions in text (pp. 22-24). in the Aspen area, at the contact between the Pennsylvanian and older

\footnotetext{
${ }^{17}$ Vanderwilt, $J$. W., Revision of structure and stratigraphy and its bearing on the ore deposits of the Aspen district, Pitkin County; Colo.: Eicon. GeoTogy, vot. 30, pp. 223-241,
1935 . 
formations. A conglomerate is also found at this horizon in the Gold Brick district ${ }^{18}$ and in the Ouray area ${ }^{18}$ (the base of the Molas formation), and according to the descriptions cited it practically matches the conglomerate described here, suggesting similar conditions at the beginning of Pennsylvanian time in these rather widely separated areas.

The several limestones, sandstones, and shales commonly change by gradation from one into another, although well-defined boundaries are also present. Most of the limestones effervesce quite readily with cold dilute hydrochloric acid, but some seem to be dolomitic. The conglomerates of Treasury Mountain (7, 9, and 13) are rather unusual rocks. Two of the beds (7 and 9 ) are to be seen on the slopes on the south side of North Pole Basin and on the east side of Bear Basin as very conspicuous white bands (see pl. 4, A), each of which, as seen from a distance, resembles the Yule Colorado marble (Mississippian). The conglomerate consists of well-rounded pebbles of white marble in a white marble matrix. On fresh fracture the pebbles and matrix do not stand out in great contrast, but on weathered surfaces the pebbles remain white while the matrix turns gray to black, which emphasizes the structure of the rock. (See pl. $4, B$.) The conglomerates are not continuous; they are thin in the section near Treasury Mountain and apparently lacking in the section from the east face of Whitehouse Mountain.

Age.-The age of the formation based on fossil evidence, according to Girty, is Pennsylvanian (possibly Pottsville). The formation in general is slightly fossiliferous, but few of the fossils are well enough preserved to be reliable indicators. In addition to the fossils listed in the detailed section (pp. 23-24) Amplesous? sp. and Lophophyllum? sp. were collected at the head of Yule Creek. Fragments of cup corals and brachiopods are fairly common, and an intensive seareh would undoubtedly yield considerable diagnostic material.

\section{PERMIAN AND PENNSYLVANIAN(?) (MAROON FORMATION)}

Distribution.-A series of maroon to red sandstones, grits, and shales, with numerous strata of gray conglomerate, commonly referred to as the "red beds", lie above the Hermosa (?) formation in the Snowmass Mountain area. They are found on the Treasure Mountain dome, where they have the same general areal distribution and structural relations as the underlying beds, and in the northeastern part of the area, east of the Elk Mountain fault. These beds on the Treasure Mountain dome, though not actually continuous in outcrop, without doubt are at the same stratigraphic horizon

\footnotetext{
${ }^{18}$ Crawford, R. D., and Worcester, P. G., Geology and ore deposits of the Gold Brick district. Colo.: Colorado Geol. Survey Bull. 10, pp. 63-64, 1916.

10 Burbank, W. S. Revision of geologic structure and stratigraphy in the Ouray district of Colorado, and its bearing on ore deposition: Colorado Sci. Soc. Proc., vol. 12, no. 6, pip. 161-162, 1930 :
} 
as the red strata lying east of the Elk Mountain fault, which are a part of the Maroon formation of the Anthracite and Crested Butte quadrangles. The Maroon as defined in the Anthracite-Crested Butte folio contains some beds included in the Hermosa in this report, but the lower limit as established by Spurr in the Aspen district corresponds to the base of the Maroon described on the Treasure Mountain dome.

In the northeastern part of the area this formation composes the crest of the Elk Mountains between the granodiorite of Snowmass Mountain, to the north, and of the White Mountains, to the south, in the Crested Butte quadrangle only a few miles southeast of this area. These beds occur in continuous exposures beyond the limits of the area to the northeast as far as the Aspen district, about 10 miles distant. To the southwest the Maroon formation is bounded by the Elk Mountain fault, along which the beds have been thrown up into contact with Jurassic and Cretaceous (Dakota? and Mancos) formations. The base of the Maroon is not exposed along the fault, and the beds are closely folded and crushed and in places overturned throughout a zone that is locally over 4,000 feet wide.

Lithologic character and thickness.-The area does not offer a section suitable for detailed measurement or study of the stratigraphy of the Maroon formation. On Treasure Mountain an unknown thickness has been removed along the unconformity, and the beds are altered. In the northeastern part of the area not only are both base and top of the formation absent but no specific horizon can be traced far or correlated with horizons elsewhere. Along the fault the beds are overturned, and in addition they may be duplicated. The best and most continuous exposure of the formation occurs on the west slopes of Maroon Peak (pl. 5, A), fully 3,000 feet east of the fault zone, where 4,000 feet of strata, dipping $5^{\circ}-10^{\circ} \mathrm{E}$., appear to lie in normal position. How great a thickness of Maroon beds there may be below these strata is not known. East of Maroon Peak the beds, with an easterly dip, appear to be continuous as far as the Aspen district, 10 miles away. This necessarily represents a great stratigraphic thickness, but the acutal amount was not determined. In the Crested Butte area Eldridge ${ }^{20}$ recorded 2,500 feet of the "red beds", but in the northern part of the Snowmass Mountain area, along Copper Creek, I measured only 1,000 feet. As all these beds are missing along Yule Creek under an uneonformity in the southern part of the Snowmass Mountain area, it would seem that the "red beds" now found in the Crested Butte area represent a remnant of the original series, which increases in thickness toward Maroon Peak and Aspen, to the north. The thickness of the "red

\footnotetext{
${ }^{20}$ Eldridge, G. H., Geol. Survey Geol. Atlas, Anthracite-Crested Butte folio (no. 9), p. 6,1894 .
} 
beds" in the Aspen district, according to Spurr, ${ }^{20 \mathrm{a}}$ is estimated at 6,600 feet, 2,600 feet of which he called Triassic. However, in Woody Creek, just north of the Aspen district, the "red beds" are about 9,000 feet thick. ${ }^{21}$

On the Treasure Mountain dome the greatest thickness of the Maroon formation occurs in the vicinity of Crystal, where it is about 2,400 feet thick, as exposed along the North Fork of the Crystal River just north of the town. (See pl. 5,B.) The full section of the beds does not crop out in a position advantageous for study, and as many lithologic features are much changed by metamorphism, a detailed measurement was not attempted. In general, above the limestone taken as the top of the Hermosa (?) formation the section shows 300 to 400 feet of hornfels, which is very sandy in places and the lower beds of which are like some of the hornfels interbedded with the limestones below. These beds make conspicuous cliffs on the north face of Whitehouse Moutain and are well exposed on the south slope of Sheep Mountain. They are also present on Crystal Mountain but not in a position favorable for study. The upper beds of hornfels contain some medium-grained sand, and this grades upward into medium-grained feldspathic sandstone 200 to 300 feet thick, which in places is, conglomeratic. These beds are very well exposed on the north, east, and west slopes of Galena Mountain, along the trail on the South Fork of the Crystal River northeast of Crystal Peak, and along the road just east of Lizard Lake. Upward the medium-grained feldspathic sandstones grade into beds of coarser feldspathic grits and conglomerates 1,500 to 1,800 feet thick. The conglomerate is composed of marbleized limestone, some quartzite, chert, and a few pre-Cambrian pebbles of granite or gneiss 1 to 3 inches across in a matrix of medium- to coarse-grained feldspathic sandstone. In the vicinity of Treasure Mountain the conglomerates are practically confined to the north side of the Crystal River on the south slopes of Mineral Point and Sheep Mountain. Farther south they have been eliminated by the erosion represented in the angular unconformity below the Jurassic.

The Maroon beds are known to change rapidly even in short distances along the strike, and a definite sequence of stratigraphic units has not been recognized. On Copper Creek, only a few miles southeast of the area of this report, in the Crested Butte quadrangle, the following series of red beds assigned to the Maroon in the Anthracite-Crested Butte folio were found overlain by Jurassic sandstone:

${ }^{202}$ Spurr, J. E., op. cit. (Mon. 31), p. 38

s. Johnson, J. H., personal communication. 
35. Red sandstone, medium- to coarse-grained, feldspathic, micaceous, and cross-bedded. This interval contains beds of conglomerate that are almost evenly spaced and have the following thicknesses : 1-14 feet, 1-10 feet, 2-5 feet, and 9-3 feet. The conglomerates are invariably white to gray and contain pebbles chiefly of limestone, but some of chert quartz and a few of pre-Cambrian granite and gneiss

34. Red sandstone, medium-grained

33. Conglomerate, white to gray, like bed 35_----------- 6

32. Red sandstone, medium-grained._-_ 66

31. Conglomerate, like bed 35

30. Red sandstone, medium-grained and thin-bedded_-_-_-_-_ 35

29. Conglomerate, like bed 35.- 10

28. Red sandstone, medium-grained and thin-bedded_-_-_-_-- 91

27. Conglomerate, like bed 35

26. Red sandstone, fine-grained, mottled with gray, and some shaly beds

1

18. Gray shale, sandy and micaceous a preceding paragraph.

This section probably represents only a small part of the original thickness of the Maroon formation but shows the change upward from finer-grained sandstones and shales into sandstones and conglomerates similar to the sequence described along the valley of the Crystal River.

\section{CORRELATION OF PALEOZOTC FORMATIONS}

The Paleozoic sedimentary rocks exposed on the Treasure Mountain dome are surrounded by Cretaceous formations. The Maroon formation easst of the Elk Mountain fault forms continuous outcrops to the Aspen district, but outcrops of older Paleozoic formations are 15 to 30 miles distant. A few fossils were found in the Hermosa (?) formation, a few corals in the Leadville, and no fossils in lower formations, so that correlation is limited to lithologic and stratigraphic features. Due allowance must be made for the changes in lithology' produced by metamorphism. Original textures and color contrasts have been obliterated, but the original mineral compositions 
of quartzite, limestone, and shale are almost unchanged, and dolomites are easily identified by the serpentine and diopside they contain. Everywhere the fundamental character of the section is recognizable, and by matching columnar sections of neighboring areas satisfactory correlations can be made. A correlation of the prePennsylvanian formations has been made thus by Vanderwilt and Fuller, ${ }^{22}$ and their chart, revised and enlarged to include columnar sections from Aspen and Leadville, is shown in figure 3. The Hermosa (?) and Maroon formations are not included in the chart, because complete sections of these formations were not available. However, their lithology is very characteristic, and they are tentatively correlated with typical Hermosa and typical Maroon.

Ordinarily the Cambrian quartzite cannot be mistaken easily for any other formation. Owing to metamorphism, however, the Dakota (?) quartzite (Cretaceous), the Parting member of the Chaffee formation (Devonian), the Harding quartzite (Ordovician), and the Entrada sandstone (Jurassic) are all dense quartzites that could be confused in poor outcrops with the Cambrian quartzite. The exposures on Treasure Mountain are excellent, and their correlation as shown in figure 3 is without question.

The Ordovician here as elsewhere in Colorado is recognized by its stratigraphic position above Cambrian quartzite and below the Parting member of the Devonian. The two upper formations, Harding quartzite and Fremont limestone, are not found anywhere north of the Snowmass Mountain area. They are thin formations but very. persistent within the area. Kirk ${ }^{23}$ has shown the Harding sandstone to be present throughout the region between its type locality, near Canon City, and Cement Creek. Treasure Mountain, about 15 miles north of Cement Creek, is the northernmost place at which the Fremont limestone and Harding sandstone have been recognized.

The base of the Devonian Chaffee formation is well marked by its Parting member, which is one of the best horizon markers in the Paleozoic section in Colorado. The Parting member has in the past been referred both to Ordovician and Devonian age. Kirk ${ }^{24}$ recently included it with the Devonian. The Parting is remarkably uniform in thickness, for so thin a member, over relatively large areas. Its rapid changes in lithology along the strike are in marked contrast to the uniformity of other formations and constitute a means for identification. The name "Parting" has been too much associated

Vanderwilt, J. W., and Fuller, H. C., Correlation of Colorado Yule marble and other early Paleozolc formations on Xule Creek, Gunnison County, Colo. : Colorado Sci. Soc. Proc., vol. 13, no. 7. pp. 439-464, 1935.

- Kirk, Edwin, The Harding sandstone of Colorado: Am. Jour. Sci., 5th ser., vol. 20, pp. $456-466,1930$. 1881.

Kirk, Edwin, The Devonian of Colorado: Am. Jour. Scl., 5th ser., vol. 22, pp. 222-240, 


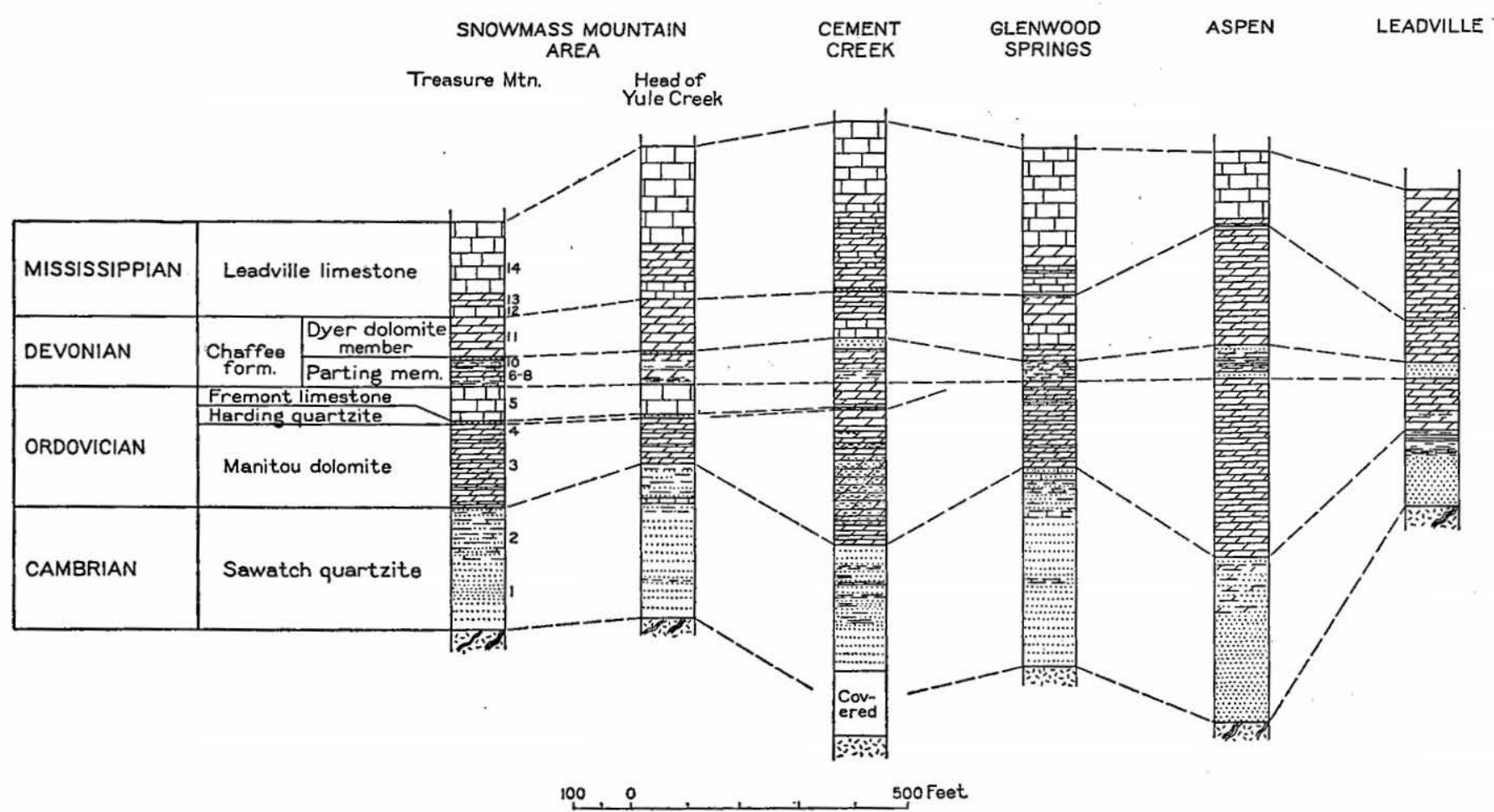

Frouga 3.-Correlation of pre-Pennsylvanian rocks found on Treasure Mountain dome with those of neighboring areas. The numbers correspond to those used for detailed descriptions in text (pp. 13-20). 
with quartzite, particularly in the Leadville district, where, as Loughlin ${ }^{25}$ has pointed out, the shale and limestone components have attracted little or no attention. The prevailing notion that the Parting must be largely quartzite has led in places to mistaking the Harding sandstone as well as other sandstone beds for the Parting. The Parting member need not be confused with any other member if its true lithologic character is considered. The description of nearly every section from central Colorado clearly shows that the Parting is present but not everywhere primarily quartzite; in the sections that I examined in the field shale and limestone were generally more prominent than the published descriptions would lead one to believe. The importance of this member has been pointed out by many writers, but even so it seems to be underemphasized rather than overemphasized. The Parting and Dyer dolomite members are readily matched with similar members in other areas, as shown in figure 3.

The Mississippian (Leadville) limestone is readily recognized wherever it is found in association with the overlying shaly limestones of the Pennsylvanian Hermosa (?) formation. The base of the formation is less distinct, but the sandy beds used for correlation occur without much question at the same horizon in the areas where they could be located.

The correlation of Pennsylvanian rocks with the Hermosa formation of southwestern Colorado is based on fossil evidence and lithologic similarity. The red beds are continuous with the typical Maroon formation in the type area, on Maroon Creek and in the Aspen district. The Maroon formation was formerly regarded as Pennsylvanian because of. its fauna, but more recently David White, in studying the flora along the Colorado River at Minturn and at Red Cliff, has concluded that the red beds are chiefly if not wholly Permian. The Permian beds as defined by White are continuous with the Maroon in the Aspen district.

The gradation from Pennsylvanian to Permian formations in this area seems apparent from the descriptions of the sections. In the Aspen area ${ }^{26}$ the base of the Maroon formation is marked by a gypsum bed that crops out along the Roaring Fork Valley and on the west and south flanks of the White River Plateau. The gypsum is present about 12 miles northwest of Treasure Mountain on the west side of Mount Sopris, and a little gypsum was found in the saddle between Snowmass and Hagerman Peaks, where the beds are much disturbed and altered near the contact of the granodiorite. On Treasure Mountain it is not present, nor could it be found in areas to the south or southeast.

\footnotetext{
${ }^{25}$ Emmons, S. F., Irving, J. D., and Loughlin, G. F., Geology and ore deposits of the Leadville mining district, Colo.: Geol. Survey Prof. Paper 148, pp. 30, 31, 1927.

${ }^{28}$ Spurr, J. E., Geology of the Aspen mining district, Colo.: Geol. Survey Mon. 31, pp. $33-37,1898$.
} 


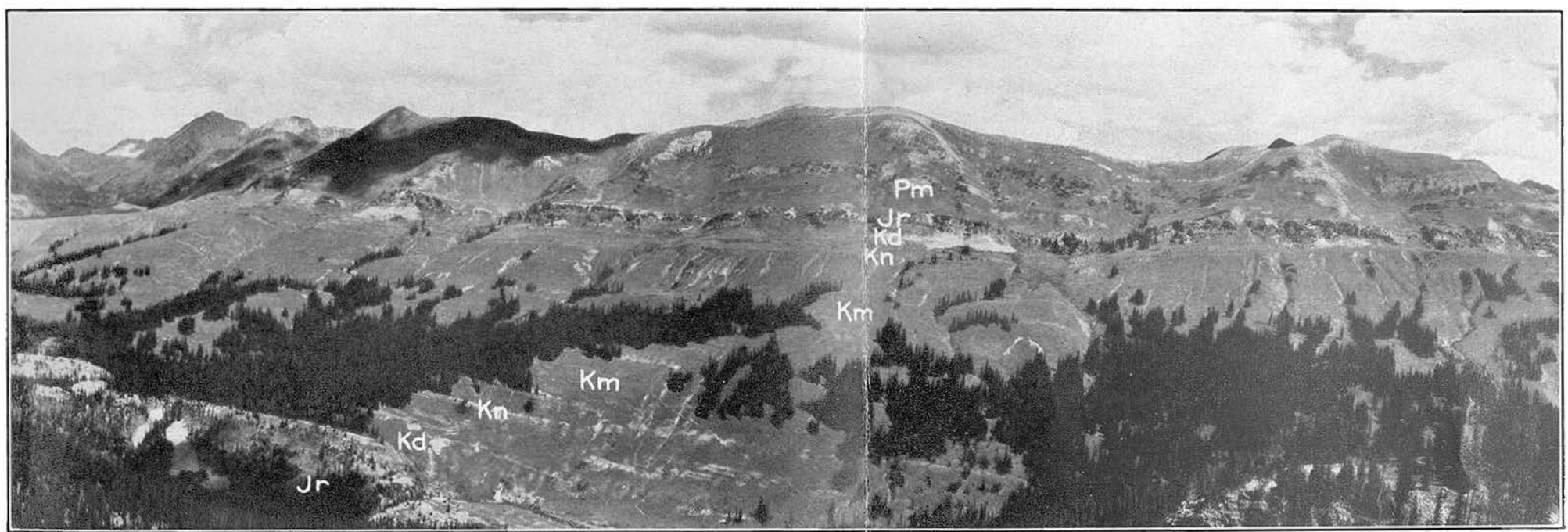

A. JURASSIC ROCKS AND CRETACEOUS DAKOTA (?) OUARTZITE AND MANCOS SFALE OVERTURNED ALONG ELK MOUNTAIN FAULT AND IN THEIR NORMAL POSITION ALONG THE CRYSTAL RIVER ON THE NORTHEAST FLANK OF TREASURE MOUNTAIN DOME.

View northeast of Galena Mountain. Triangulation point Crystal (altitude, 12,492 feet) is on high roint near center of panorama. Km, Mancos shale; Kn, limestone of Niobrara age in the Mancos; Kd, Dakota (?) quartzite; Jr, Jurassic rocks; Pm, Maroon beds.

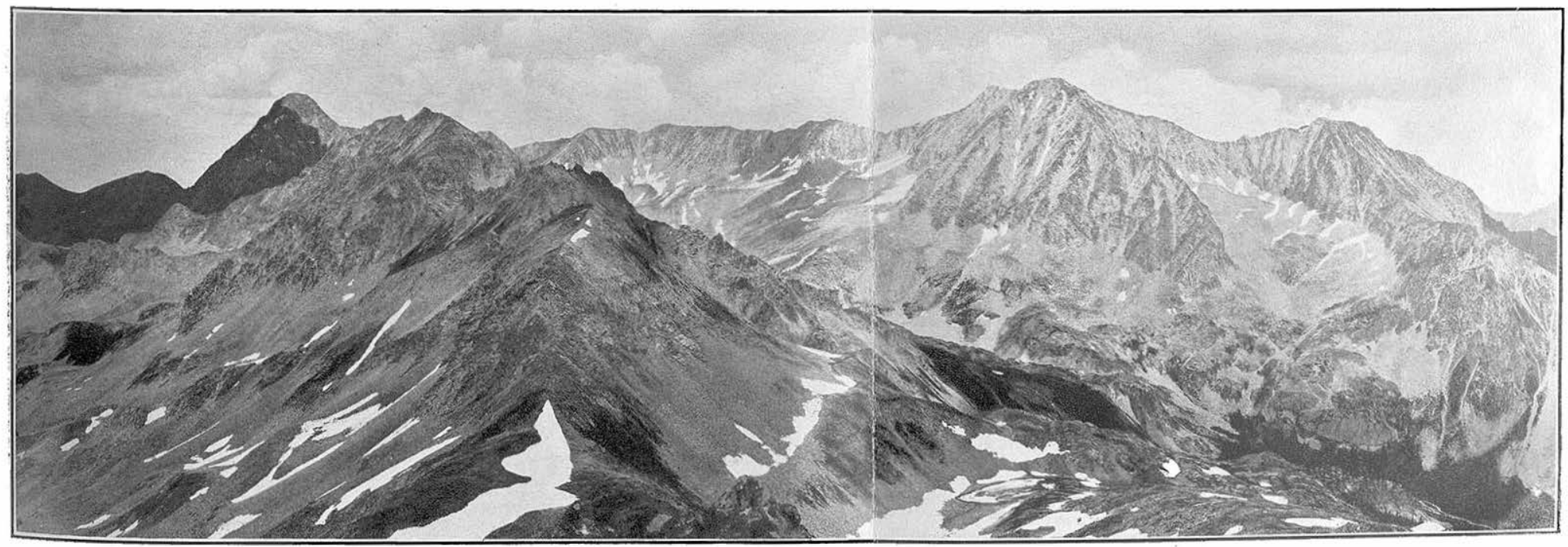

B. RUGGED TOPOGRAPHY AND HIGH RELIEF FORMED BY RESISTANCE TO EROSION OF ROCK OF THE SNOWMASS MOUNTAIN INTRUSION. Snowmass Mountain is high peak at right. High peak at left is Capital Peak, which is north of the limits of the area. View from the west. 


\section{MESOZOIC SEDIMENTARY ROCKS}

\section{JURASSIC FORMATIONS}

\section{GENERAL DESCRIPTION}

The Mesozoic sedimentary rocks in the Snowmass Mountain area include four formations - the Entrada sandstone and Morrison formation, of Upper Jurassic age, and the Dakota (?) quartzite and Mancos shale, of Upper Cretaceous age. The Dolores formation (Triassic and Jurassic?) of nearby regions has not been recognized in the Snowmass area, though it is present near Aspen and along the lower part of the Crystal River.

The Entrada sandstone, the basal formation of the Mesozoic of the general region, is present in the area northwest of the Snowmass area along the Crystal River, and it is present also toward the east, in the vicinity of Aspen. It is not known to occur in the area to the south and west along the Gunnison River. To the west for many miles Tertiary strata cover the horizon of the Entrada, and its presence or absence is not known. A somewhat similar discontinuous sandstone forms the basal part of the Morrison formar tion at many places in the general region and is particularly difficult to separate from the Entrada where both are more or less metamorphosed. It is possible that in the Snowmass area only the basal sandstone of the Morrison is present, though it is more probable that the two sandstones occur and that they have been confused. The zone of quartzite that lies across the beveled edges of the Paleozoic strata contains quartz grains of two sizes so characteristic of the Entrada in other areas, and on this evidence it is assignable to the Entrada, although Morrison sandstone may be associated with it in places. This sandstone zone and the overlying Mesozoic beds crop out in a continuous band around the Treasure Mountain dome. These formations are also found in an overturned position along the west side of the Elk Mountain fault, where the section between the lower part of the Mancos shale and the Maroon formation is essentially complete except for local squeezing and minor faulting. (See pls. 1 and $6, A$.)

\section{ENTRADA SANDSTONE}

Distribution.-The sandstone zone that in adjacent regions is known to include Entrada sandstone and the immediately overlying Morrison formation was until recently commonly included under the name $f$ "Gunnison formation." ${ }^{27}$ The general distribution of the

\footnotetext{
${ }^{27}$ A dagger ( $\dagger$ ) preceding a geologic name indicates that the name has been abandoned or rejected for use in classification in publications of the Geological Survey. Quotation marks, formerly used to indicate abandoned or rejected names, are now used only in the ordinary sense.
} 
entire Jurassic sequence is briefly outlined above. Locally the Snowmass Mountain intrusion has cut across the Elk Mountain fault zone and has eliminated the Jurassic (see pl. 1), which, however, continues along the fault on the northwest side of the intrusion for several miles beyond the limits of this area. To the south, southeast of the divide north of Mount Belleview, the Jurassic rocks have been cut out under a thrust surface of the fault.

The most accessible sections that probably include both the Entrada sandstone and the Morrison formation are (1) just northwest of Lizard Lake on the road from Marble to Crystal and (2) along the trolley track about half a mile northwest of the Yule Colorado marble quarry. Good exposures also occur along the trail from Crystal to Lead King Basin and just below or northwest of Schofield Park. The Entrada sandstone as recognized in the Snowmass Mountain area may include some areas of sandstone of Morrison age.

Lithologic character and thickness.-The Entrada sandstone, which is normally composed of well-sorted white quartz sand, resembles other sandstones of the Jurassic in general appearance. Where exposures are sufficiently good it can be recognized easily. The Entrada of western Colorado and eastern Utah is distinguishable from other sandstones of the Jurassic by the fact that in places some layers of the rock contain grains of two sizes. ${ }^{28}$ The larger grains are subangular to well rounded, have frosted surfaces, and are commonly from 25 to 28 millimeters in maximum dimension. These large grains in any particular specimen are three to five times as large as the smaller ones. The two sizes of grains are not present in every layer but can usually be found on any good outcrop and afford a reliable means of identifying this sandstone, which otherwise resembles sandstones found at higher horizons in the Jurassic as well as some of those in older and younger formations. This character of two sizes of grains has been found at every exposure examined in the Snowmass area, and it supports the identity of the Entrada sandstone. On the Treasure Mountain dome the normal sandstone has been metamorphosed to a dense quartzite. The quartzite, 15 to 45 feet thick, is not conspicuous and resembles other quartzites except for the presence of grains of two sizes.

Age and correlation.-The Entrada sandstone and the immediately overlying Morrison formation compose the fGunnison formation of the Anthracite-Crested Butte folio. Recent regional stratigraphic studies ${ }^{29}$ have resulted in identifying the Entrada sandstone of southeastern Utah over considerable areas in western Colorado and in Gunnison County. Because of the thinness of the whole zone of sand-

\footnotetext{
28 Baker, A. A., Dane, C. H., and Reeside, J. B., Jr., Correlation of the Jurassic formations of parts of Utah, Arizona, New Mexico, and Colorado: Geol. Survey Prof. Paper 183, p. 7, 1936.

20 Idem, pp. 16-21, 23, 26-28.
} 
stone at the base of the Mesozoic, the sandstone has not been separated from the Morrison formation in mapping, though it is deemed worth while to recognize the probable presence of the Entrada in the sequence of rocks of this area.

The Entrada sandstone at its type locality in eastern Utah lies between formations that carry marine invertebrate faunas of Upper Jurassic age ${ }^{30}$ and is therefore definitely assigned to the Upper Jurassic. There is no reason to doubt the Jurassic age of the Entrada sandstone of the Snowmass area, and it is so assigned.

\section{MORRISON FORMATION}

Lithologic character and thickness.-The Upper Jurassic Morrison formation consists of variegated shales, interbedded sandstones, and some limestones. It has a very characteristic development over large areas and when taken in its entirety need not be confused with any other formation. Different parts of the formation, however, vary in their development and in the persistency and thickness of individual beds and members, so that correlation of different members must be attempted with caution. Throughout the Elk Mountains the variations within the formation are less than they are in the western part of the State, and for this reason satisfactory correlation of exposures is not difficult.

A complete section suitable for detailed measurement was not found within the Snowmass area, but an excellent section of the Morrison formation and the underlying Entrada sandstone on the divide on the north side of Copper Creek in the Crested Butte quadrangle, only a few miles to the southeast, was studied. The section is given in detail not because individual strata are considered important but to bring out the composition of the formation.

The formation is divided into two lithologic units, as indicated below by 1 and 2 , each of which is readily recognizable throughout the Snowmass Mountain area. It is underlain by Permian "red beds" and overlain by Dakota (?) quartzite.

Section measured on the divide on the north side of Copper Creek east of Gothic, Crested Butte quadrangle

Morrison formation:

Feet

2. Shale, green, maroon, and gray variegated. Six lenses of gray limestone 2 to 6 inches thick-

Sandstone, fine-grained, gray, with some interbedded

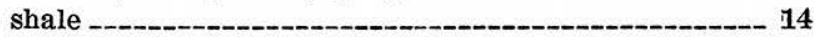

Shale, maroon to yellow

Sandstone, gray to red, fine-grained___-_-_-_-_-_-_-_ 8

Shale, greenish gray and gray to buff-_-_-_-_-_-_-_-_ 11

Sandstone, fine-grained, gray-_._-_._- 12

oBaker, A. A., Dane, C. H., and Reeside, J. B., Jr., op. cit., pp. 7, 8. 
Scction measured on the divide on the north side of Copper Creek east of Gothic, Crested Butte quadrangle-Continued

Morrison formation-Continued.

Shale, maroon and green, with red sandstone inter-

bedded

Feet

Sandstone, gray, fine-grained.

24

Shale, red to gray and green; upper part sandy

Shale, gray, sandy-_-_- 16

Shale, calcareous, gray, alternating with beds of sandstone and some limestone.

Limestone, gray, dolomitic

Shale, gray

Limestone, gray, dolomitic

Shale, gray to red, calcareous, with thin beds of limestone.

Limestone, gray

Shale, gray to red, calcareous___-_-_-_-_-_-_ 5

Limestone, dolomitic, gray mottled with red_-_-_-_-_-_- 4

Shale, calcareous, gray, in places mottled red.--.---.-- 12

Sandstone, calcareous, gray, fine-grained, well bedded_- 27

1. Limestone, gray, dense, in beds 2 to 14 inches thick; 10

feet of dolomite at base-__-_- 30

Sandstone, calcareous, gray, fine-grained__-_-_-_-_-_-_ 5

Shale, sandy, green to brown

Entrada sandstone: Sandstone, brown to gray, fine-grained, well bedded, upper part calcareous and slightly friable 30

Permian red beds (Maroon formation).

The limestone unit 1 varies in composition and thickness but seems to be widespread in its occurrence. On Copper Creek the limestone is relatively pure and thick. In the Snowmass Mountain area this unit ranges from 15 to 30 feet in thickness and contains much interbedded shale, but although the relative proportion of limestone to shale varies greatly, some limestone is present throughout the Snowmass Mountain area. The limestone very commonly contains fossil algae in some of its beds and in a few places contains poorly preserved fresh-water fossils (Unio?). Fossil algae are not considered reliable for correlation over long distances, but in this area they were found useful, as they: are consistently present and have not been found at any other horizon.

Unit 2, above the limestone, is largely shale and as a unit is readily recognized by its thickness and its variegated colors of green, red, and maroon. The limestones and sandstones found in the shale are lenticular; the lenses are not confined to any one stratum nor are they better developed at one horizon than at another.

Along the Elk Mountain fault within the area studied these two lithologic units of the Morrison are well exposed and normal in their development except, of course, that the formation is overturned, so that the shale sequence 2 lies below the limestone unit 1 . 
On the Treasure Mountain dome the Morrison formation has been metamorphosed. Instead of limestone there is white marble, and instead of partly covered slopes of variegated shales there are bold cliffs of gray to pale-green hornfels. In spite of these changes the two units are very good horizon markers. The marble zone (unit 1) is also characteristic, and when associated with the bed of Entrada quartzite, below, it cannot be confused easily with any other unit either in younger or older beds. The upper unit (2) of gray to palegreen hornfels is no less characteristic than the variegated shales it represents. Beds of similar hornfels are found both in the Pennsylvanian and in the Permian, but they are thin in contrast to the hornfels of the Morrison formation.

Age and correlation.-The Morrison formation composes the upper and principal part of the fGunnison formation of the AnthraciteCrested Butte folio. The work of recent years by several geologists, chiefly by A. A. Baker, C. H. Dane, and J. B. Reeside, Jr., has resulted in identifying the Morrison formation over large areas west of the Front Range in Colorado, though its type locality is near the town of Morrison, on the east side of the Front Range. The formation has also been delimited throughout much territory in northwestern New Mexico and southeastern Utah.

The age of the Morrison formation is now generally accepted as Upper Jurassic.

\section{CRETACEOUS FORMATIONS}

\section{DAKOTA (?) QUARTZITE}

Distribution.-A thick series of quartzite beds rests on the Morrison formation (Upper Jurassic) and is in turn overlain by the black Mancos shale. The quartzite crops out parallel to the Morrison formation around the Treasure Mountain dome and along the Elk Mountain fault. The most accessible exposure occurs along the road from Marble to Crystal. However, many excellent outcrops occur in numerous places along both Yule Creek and the Crystal River. The quartzite occurs at the horizon of the Dakota sandstone to the east, and for that reason it is here tentatively called Dakota (?) quartzite.

Lithology and thicleness.-The Dakota (?) quartzite consists largely of relatively pure fine-grained quartzite with shale partings and some shaly beds in places. On the divide on the north side of Copper Creek, the Dakota (?) quartzite is 205 feet thick. The distribution of the shale in the section on Copper Creek is shown in the following section: 
Section of Dakota (?) quartzite on Copper Creek, Orested Butte quadrangle

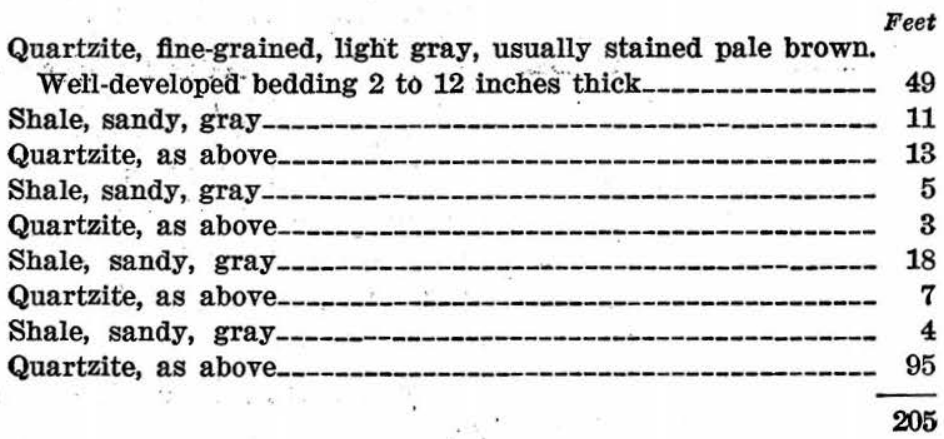

At the base of the formation is a characteristic conglomerate ranging in thickness from 4 feet to the vanishing point, composed of well-rounded pebbles of white, gray, black, yellow, and red quartz or chert. The pebbles average a quarter of an inch across and are set in a fine-grained matrix of quartz sand. This conglomerate proved very useful in recognizing the base of the Cretaceous quartzite in the Snowmass Mountain area.

Near the head of Yule Creek and in the vicinity of the quarry of the Yule Colorado Marble Co., where this quartzite is best exposed, it is 160 feet thick.

The basal conglomerate is not absolutely continuous but is so persistent as to constitute a very convenient marker of the base of the Dakota (?) quartzite. In one place it was noted about 5 feet above the actual base of the quartzite. The lithology of the quartzite is uniform, and the shale, which is concentrated in the central part of the formation, is appreciably less than in the section on Copper Creek. In places shale beds are almost entirely lacking, but some shale partings are invariably present at irregular intervals throughout the formation. As a rule the upper few feet of the quartzite is shaly, and a few thin beds of quartzite occur in the Mancos shale several feet above its base; so the change from Dakota (?) quartzite to Mancos shale is gradational through a zone ranging from 2 to 10 feet in thickness.

\section{MANCOS SHALE}

DISTRIBUTION

A great thickness of dark-gray to black shale overlies the Dakota (?) quartzite. This shale surrounds the Treasure Mountain dome and also occupies the area between the dome and the Elk Mountain fault. To the north and east it is cut off by the intrusion of Snowmass Mountain and the Elk Mountain fault, but to the west and south it extends for many miles beyond the limits of the area. The upper part of the Mancos shale is not found within this area, 
although it occurs only a few miles northwest of Marble, on the west side of Carbonate Creek, and in the Anthracite quadrangle, to the southwest.

\section{LITHOLOGY AND THICKNESS}

The Mancos shale is a uniform dark-gray to black shale that readily weathers to clay. Except for a single bed of limestone of Niobrara age there are no lithologic subdivisions that can be mapped. Eldridge ${ }^{31}$ gave 2,800 feet as the thickness of this formation immediately south of Mount Baldy, in the southern part of the area, and recognized in the lower part two members, which he called Benton shale and Niobrara limestone. On the north slope of Mount Baldy the lower 2,000 feet of the Mancos shale is present, but elsewhere within the area the thickness is less, the upper part having been eroded.

Lower shate member.-The lower shale member of the Mancos shale occupies the interval above the Dakota (?) quartzite and below the limestone member and is believed to be in part the equivalent of the Carlile shale east of the Front Range. This member is 200 to 500 feet thick and in the Snowmass area is slightly less calcareous and more siliceous but nevertheless lithologically similar to the shales above the limestone member. The lower 40 to 60 feet around the Treasure Mountain dome has been metamorphosed slightly and as a result is more massive and resistant to weathering than the overlying shale. The indurated shale forms conspicuous ledges, which upon, weathering turn grayish and superficially resemble the limestone member. These beds are also present with the overturned beds along the Elk Mountain fault. Along the fault the beds are unaltered, and the lower part of the shales is noticeably more siliceous than the upper part, which is rather carbonaceous in places. The lower shales are less calcareous than the shales found above the limestone member.

Limestone member.-The limestone member of the Mancos shale as here mapped is a characteristic bed and is of economic importance as well. Reeside visited the area in 1930 and collected fossils from the limestone and from the shale below the limestone on the east side of Schofield Park. His identifications and remarks follow :

15398. Slope northeast of Schofield Park, limestone 500 feet above the Dakota (?) :

Globigerina sp.

Ostrea congesta Conrad.

Inoceramus deformis Meek.

This fauna is widespread in the lower part of the Niobrara and its equivalents.

"r Eldridge, G. H., Geol. Survey Geol. Atlas, Anthracite-Crested Butte folio (no. 9), p. $6,1894$. 
15400. A few hundred feet south of the Hercules Ajax mine, Schofield Park, shale 400 feet aboye Dakota (?) :

Inoceramus fragilis Hall and Meek.

Scaphites warreni Meek and Hayden.

Prionocyclus wyomingensis Meek.

This fauna is widespread in the upper part of the Carlile and its equivalents.

We found nothing to show the upper limit stratigraphieally of the beds above the limestone and cannot say how much of the Mancos shale they represent. It seems possible that beds of Montana age may be present on the hillside that we visited,

The limestone member is 20 to 40 feet thick and consists of limestone beds 6 to 12 inches thick with interbedded shale. The limestone is gray, and some of the strata contain numerous fragments of Inoceramus deformis. A few nearly complete specimens of these fossils were found, but they are not common. The limestone, though relatively thin, is easily traced. Even on well-covered slopes its approximate position is usually: marked by the characteristic slabs of limestone that formed as strata broke up through weathering.

Within the area the limestone has been locally called the "Lead King lime", probably because it marks the ore zone in the Lead King mine, in Lead King Basin. The term has also been applied by prospectors to the indurated lower part of the shale member, probably because the true relations were not recognized.

\section{ALTERATION}

The Cretaceous shales around the Treasure Mountain dome are not so intensely altered as the beds below the Dakota (?) quartzite. The shale is not changed to a hornfels, like the Jurassic shales just below the Dakota (8) quartzite, nor does it contain contact-metamorphic minerals, such as those found in the older formations. However, it is sufficiently indurated to make fairly good road material. In the southern part of the area the shales are indurated to a siliceous slate with a blocky fracture (see pl. 7, A); the unaltered shale readily disintegrates to elay that is very gummy and sticky when wet. In the northern part of the area the degree of induration is much less; the greater degree of alteration represented in plate $7, A$, is believed to be due to the intrusions that occur in the Ruby Range, not far to the south.

\section{AGE AND CORRELATTON}

The age of the black shales has been long established as Cretaceous on fossil evidence, and as the shales form continuous outcrops into the Anthracite quadrangle there is no problem of correlation.

\section{TERTIARY IGNEOUS ROCKS}

The Tertiary igneous rocks comprise the granodiorite of the Snowmass Mountain stock, only a part of which lies within the area, 
granite of the Treasure Mountain stock, and dikes and sills of intermediate composition. These igneous rocks have not been described previously, but the rock of Snowmass Mountain is similar to the rock of White Rock Mountain, which lies to the southeast in the northern part of the Crested Butte quadrangle, and is probably related to it. White Rock Mountain has been described as diorite by $\mathrm{Cross}^{32}$ and much later as granodiorite by Knopf. ${ }^{33}$ Some of the dikes and sills are continuous with Cross' group of "porphyrites" of the laccoliths, dikes, and sills in the Anthracite quadrangle. The granite found on Treasure Mountain has not been described and, so far as could be ascertained, is limited to this one area.

Both granodiorite and granite are younger than the series of dikes and sills in the southeastern part of the area, which, though numerous, are small individually and in total volume.

Each stock, as well as the group of dikes and sills, occurs as a unit without apparent direct relation to the other, and each stock and the dikes as a group are described separately.

\section{DIKES AND SILLS}

Gabbro porphyry, quartz monzonite porphyry, and lamprophyric rock are represented in the group of dikes and sills, most of which are confined to a zone in the southeastern part of the area. There are also a few dikes and dikelike apophyses related to the stocks, and these will be included in the description of the stocks. The only other dike outside the main zone is a dike of gabbro on Meadow Mountain, in the northwestern part of the area. Rock mineralogically similar to this gabbro is not found in the main zone of the dikes and sills to the southeast.

\section{GABBRO PORPHYRY}

Character.-The gabbro porphyry is a dark to almost black rock with chlorite and many small inconspicuous' striated feldspar phenocrysts. The plagioclase crystals $\left(\mathrm{A}_{4} \mathrm{An}_{6}\right)$ are 2 to 3 millimeters across and are partly replaced by calcite, which is also abundant throughout the groundmass. The groundmass is welli crystallized and consists chiefly of laths of labradorite with some magnetite, 0.2 by 0.6 millimeter. The magnetite grains are commonly surrounded by calcite and shreds of secondary biotite. The chlorite, of the variety antigorite, is very pale green to colorless, showing either very weak or no pleochroism, and appears to replace both calcite and the secondary quartz. Primary ferromagnesian

\footnotetext{
${ }^{32}$ Cross, Whitman, Geol. Survey Geol. Atlas, Anthracite-Crested Butte folio (no. 9), 1894.

${ }^{33}$ Knopf, Adolph, Recent developments in the Aspen district, Colo.: Geol. Survey Bull. 785, pp. 11-12, 1926.
} 
minerals are lacking. Some quartz and scattered grains of pyrite are present.

Distribution.-Gabbro porphyry was found only on Meadow Mountain and to the west on Arkansas Mountain in an isolated area, so that its relation to the other dikes is not clear. The dike is discontinuous and was either faulted after intrusion or else the magma followed an irregular fracture. The outcrops are inconspicuous in the black shale, and the dike may extend farther west on Arkansas Mountain than is shown on the map.

\section{QUARTZ MONZONITE PORPHYRY}

Character.-The quartz monzonite dikes are porphyries; they caı be divided into three groups-(1) a nearly white felsite showing only phenocrysts of quartz with very inconspicuous feldspars; (2) a gray rock with numerous phenocrysts of white feldspar 3 to 5 milli. meters across in which quartz phenocrysts may or may not be pres. ent; and (3) a gray rock like that in the second group, but with conspicuous orthoclase phenocrysts 20 to 40 millimeters across spaced at intervals of 2 to 6 inches through the rock, which is lithologically like the Lincoln porphyry in the Mosquito Range.

Under the microscope the felsite and the finer gray rock show quartz and orthoclase in the groundmass and phenocrysts of plagioclase too much sericitized or replaced by calcite for satisfactory identification. The coarser variety is also altered, but in one section plagioclase $\left(\mathrm{Ab}_{65} \mathrm{An}_{35}\right)$ was identified. The quartz grains are rounded, and some show halos. The large orthoclase crystals show only little alteration and contain numerous inclusions of quartz and plagioclase with some titanite and possibly hornblende. Chlorite is abundant throughout the rock and has largely replaced the biotite. Magnetite is not abundant, but its scarcity may be due to alteration, as leucoxene is common. Some pyrite is generally present.

Distribution.-The quartz monzonite dikes and sills are concentrated in the southeastern part of the area in a zone which trends northeastward. The porphyritic felsite on Mount Belleview is a small stocklike body that has bleached and indurated the Mancos shale, and in places in the southeastern part of the mass it is highly brecciated. The other occurrences are in the sills on Yule and Rock Creeks and, outside the main zone of dikes and sills, on Meadow Mountain, in the northern part of the area. The gray porphyritio rock with medium-sized phenocrysts occurs chiefly as sills and is confined mostly to the vicinity of Emerald Lake and the western slope of Mount Belleview. The coarser porphyritic rock with conspicuously large orthoclase phenocrysts occurs mostly in dikes that strike northeastward, parallel with the main zones of dikes and sills. ThH mass north of Mount Belleview shows some bleaching of the shales 
along the contact zone, which is nearly vertical wherever exposed, and may therefore be a small stock. Quartz and feldspar crystals are well developed in a large sill east of Snowmass Creek, northeast of the limits of this area, but the sill is not known to occur farther to the east or north on the west side of the Sawatch Range. To the south and southeast the laccoliths in the Anthracite and Crested Butte quadrangles contain similar rocks.

\section{LAMPROPHYRIC ROCKS}

The dikes of lamprophyric rock are not numerous, and they are generally small. They range in width from 2 to 8 feet and make only inconspicuous outcrops that cannot be traced far along the strike. The lamprophyric rocks in neighboring areas have not been described. In the Anthracite and Crested Butte quadrangles certain. facies of the "porphyrite" or of the dike rocks of the Ruby Range as described by Cross ${ }^{34}$ may be the equivalent of the lamprophyres of this report. In the Aspen district, to the northeast, a sill described by Knopf ${ }^{35}$ as diorite porphyry has a groundmass of quartz and albite and may be related to the lamprophyric rocks.

Character.-The lamprophyric rocks are uniformly fine-grained, are dark gray to black, and may or may not show phenocrysts. The phenocrysts are augite, hornblende, biotite, in some places feldspar; and more rarely quartz. All these rocks show evidence of alteration, and pyrite and calcite are common both in the lamprophyric rocks that appear least altered and in those that are bleached to a greenish gray. Alteration is not always apparent in hand specimens, but examination of thin sections shows that on the whole the lamprophyric rocks are more altered than the dikes of quartz monzonite.

In thin sections of the less altered lamprophyres oligoclase, augite, quartz, magnetite, hornblende, biotite, and some titanite and apatite were observed, together with such alteration products as calcite, pyrite, chlorite, biotite, epidote, augite, colorless garnet, dark-brown tourmaline, and possibly quartz. Colorless, nonpleochroic augite crystals 1 to 2 millimeters across are the most common phenocrysts, and pale-brown hornblende and biotite are next in order. The feldspar and quartz are generally confined to the groundmass, but plagioclase phenocrysts are rather common in a few places, although they are too much replaced by calcite to permit identification. A single quartz phenocryst was observed in one thin section. The groundmass consists of small laths of oligoclase with some interstitial quartz and is less altered than the phenocrysts. The amount of interstitial quartz was estimated at less than 5 percent, but it is not certain that all this quartz is primary; quartz in veinlets and lenticles is present. The

as Cross, Whitman, op. cit. (Follo 9).

${ }^{25}$ Knopf, Adolph, op. cit. (Bull. 785), pp. 7-8. 
oligoclase shows albite twinning, and its maximum index of refraction is 1.544, which indicates a composition of about $\mathrm{Ab}_{85}{ }^{A} \mathrm{An}_{15}$. The magnetite is present in small anhedral grains throughout the groundmass. Titanite and apatite were not found in any of the thin sections examined.

This rock has been classified as lamprophyric because in mineral composition it is close to lamprophyre. The sodic plagioclase and small amounts of quartz suggest a composition related to that of bostonite. However, the abundance of ferromagnesian minerals would seem to indicate a closer affinity to lamprophyre.

Alteration.-Calcite, chlorite, and pyrite were present in every thin section examined. . Some of the calcite is in veinlets, but more generally it is disseminated through the rock, and in places it is so abundant that weathered surfaces of the rock show characteristic pits, owing to differential weathering. The chlorite is felted, is pale green to colorless, and is only slightly pleochroic, if at all; it partly or completely replaces the ferromagnesian minerals and to some extent replaces calcite. The pyrite occurs in euhedral grains scattered through the rock and does not show any relation to magnetite or other minerals that it may have replaced. In those places where epidote, garnet, and tourmaline are abundant in the area these minerals have also formed in the dikes, and locally they have completely replaced. the primary minerals. Biotite regarded as secondary occurs locally in flakes and stringers in places in the groundmass, as sericite commonly occurs in feldspar. Where tourmaline and garnet are well developed augite may occur in an association strongly suggesting its secondary origin.

Relative age.-The dikes; with the possible exception of the gabbro porphyry dike, are the oldest Tertiary igneous rocks in the area. All the quartz monzonite and lamprophyric dikes have been metamorphosed by the Treasure Mountain stock of granite, and a dike of quartz monzonite with large orthoclase phenocrysts was found to be cut by the Snowmass. Mountain intrusion and to be enclosed in it.

On the west slope of Mount Belleview a lamprophyric dike was found to cut a quartz monzonite porphyry sill containing large orthoclase phenocrysts. The sill in turn cuts quartz monzonite porphyry that is free from large orthoclase crystals, and the lamprophyric dike also cuts the stocklike mass of porphyritic felsite. Other age relations were not observed.

\section{CORRELATION}

The quartz monzonite porphyry with large orthoclase phenocrysts is continuons to the south in two places with rock described by Cross ${ }^{36}$ that is common in several laccolithic intrusions occurring in

${ }^{30}$ Cross, Whitman, op. cit. (Folio 9). 
the West Elk Mountains. A porphyritic felsite sill at the head of the Slate River in the Anthracite quadrangle continues into the head of Rock Creek. Several of the large laccoliths, including Gothic Mountain, only about 5 miles south of the main zone of dikes, are described by Cross as follows:

The rocks here called porphyrite are distinctly porphyritic rocks, exhibiting many white plagioclase crystals, with quartz, biotite, and occasionally hornblende, and, in most cases, very large glassy crystals of orthoclase, often 2 to 3 inches in diameter.

Cross also implies that the "porphyrites" show a sequence of intrusion, which, however, he does not discuss in detail.

In the Mosquito Range the Lincoln porphyry is quartz monzonite with large feldspar phenocrysts that lithologically and mineralogically resembles the coarser quartz monzonite porphyry referred to above, and on this basis they are tentatively correlated, although it must be remembered that the two areas are separated by a distance of nearly 40 miles, in which the rock is not known to occur.

\section{GRANITE OF TREASURE MOUNTAIN STOCK}

Treasure Mountain, in the southwestern part of the area, is a structural dome dissected by erosion so as to expose the structure in a striking manner. Holmes ${ }^{37}$ briefly described the structural features of Treasure Mountain and on his geologic map showed its intrusive core. The granite is exposed both along the Crystal River on the north flank of the dome and in Yule Creek on the south flank not far from the central part of the dome. It is surrounded by sedimentary beds that separate it from all the other igneous rocks. It is the only post-Cretaceous granite known in the Elk and West Elk Mountains, which abound in intrusions of dioritic and monzonitic rocks.

\section{GENERAL CHARACTER}

The granite is a massive pale-pink rock that appears nearly white in outcrop, especially from a distance. In hand specimens the pink color is most pronounced in the well-crystallized porphyry facies, owing to the fact that in that facies the groundmass is more nearly white and the pink color is essentially concentrated in the orthoclase phenocrysts. The rock is generally medium- to coarse-grained and in addition to pink feldspar usually shows abundant quartz and some biotite.

A porphyritic marginal facies of the granite, which has phenocrysts of pink orthoclase in a fine-grained groundmass of the same composition, is present nearly everywhere along the contact but

\footnotetext{
${ }^{37}$ Holmes, W. H., [Report on the geology of the northwestern portion of the Elk Range] : U. S. Geol. and Geog. Survey Terr. 8th Ann. Rept:; p. 67, 1876.
} 
is best-developed along the Crystal River, where it crops out over relatively large areas. The proportion of phenocrysts ranges from virtually nothing to perhaps 90 percent. Where they are most abundant the groundmass is recognizable only in thin section. The relative amount of quartz and pink orthoclase phenocrysts is not constant, and biotite or other ferromagnesian minerals are either very inconspicuous or in many places entirely lacking. The groundmass is very pale pink to white and granular but too fine-grained to distinguish the quartz from the orthoclase with a hand lens.

Irregular masses and small stringers of pegmatite composed of pink orthoclase and quartz and aplite dikes of the same composition occur in the granite. These pegmatites and aplites are common only in the upper part of Bear Basin and in Yule Creek; none were observed at lower altitudes along the Crystal River, where the porphyritic marginal facies or porphyry is well developed. All the thin sections show an abundance of quartz and orthoclase, considerable albite, and only minor amounts of either biotite or magnetite. A few grains of titanite and apatite were observed in thin section. In the granitoid facies the grain size averages 2 to 4 millimeters and the pink orthoclase crystals tend to be larger than this average, and the quartz grains smaller. The orthoclase is everywhere clouded and contains much perthitically intergrown albite, a small percentage of which is also found in separate grains. Biotite is green or brown and about equal in amount to magnetite, which occurs in small anhedral grains. The porphyritic phase found along the margin of the stock contains phenocrysts ranging from 1 to 5 millimeters in length, but in a given specimen the size is uniform. The quartz phenocrysts are generally rounded, in places conspicuous, and as a rule subordinate to the orthoclase. The orthoclase phenocrysts do not contain perthitically intergrown albite, which is so common in the granitoid facies. Albite is confined to the groundmass except for occasional anhedral phenocrysts. The groundmass is a wellcrystallized uniform mosaic of quartz, orthoclase, and albite with an average grain size of about 0.1 millimeter. Several thin sections contained no biotite and magnetite; these minerals are nowhere abundant except in a few places near the contact with biotite gneiss or sedimentary rocks in which much biotite is present.

\section{CHEMICAL COMPOSITION}

A specimen for chemical analysis was selected in Bear Basin from the bottom of the gulch that was estimated to be at least 500 feet below the projected contact of the granite or top of the stock. The rock is pink and in hand specimen shows the typical quartz and pink orthoclase and a subordinate amount of biotite. The albite, mostly as perthite, is evident only under the microscope. A little 
magnetite and pale-green biotite are present as well as a few grains of muscovite and a very little sericite.

Analysis of pink granite from Bear Basin

[J. G. Fairchild, analyst]

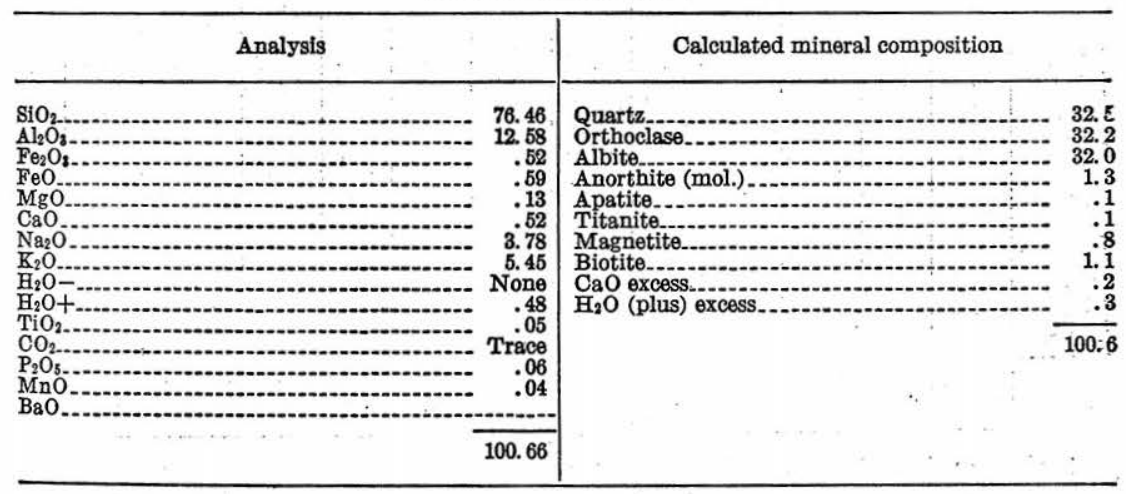

Beginning with orthoclase the minerals were calculated in the order given and, except the anorthite molecule, represent the minerals observed in thin section. The essential minerals quartz and feldspar constitute 98 percent of the rock; biotite and magnetite are the only visible accessory constituents. It is not evident where the excess water may belong, as the combined amount of sericite observed in thin sections and the small amounts of hydrated iron or manganese oxides that may be present can account for only a very small part of it. The cloudiness of the orthoclase could possibly be due in part to certain clay minerals, but 0.33 percent of water would imply about 2 percent of clay, and it should be accompanied by a corresponding excess of alumina.

The mineral and chemical composition show the rock to be a sodic granite or alaskite. Facies of the dioritic rock of the stock of White Rock Mountain and of the dike rocks of the Ruby Range are described by Cross $^{38}$ as granite, but chemical analyses or detailed petrographic descriptions of these granite phases are not available. Tertiary igneous rocks of similar chemical composition are found in several places in the State, and their analyses are shown for comparison in the accompanying table, which includes stocks, laccoliths, sills, flows, and a dike. The dike of bostonite is included because analyses of more siliceous rocks, such as rhyolite and alaskite of Tertiary age from the Front Range, have not been made.

${ }^{3}$ Cross, Whitman, op. cit. (Folio 9). 
Chemical analyses of Tertiary igneous rocks in Colorado compared with analysis of granite from Treasure Mountain

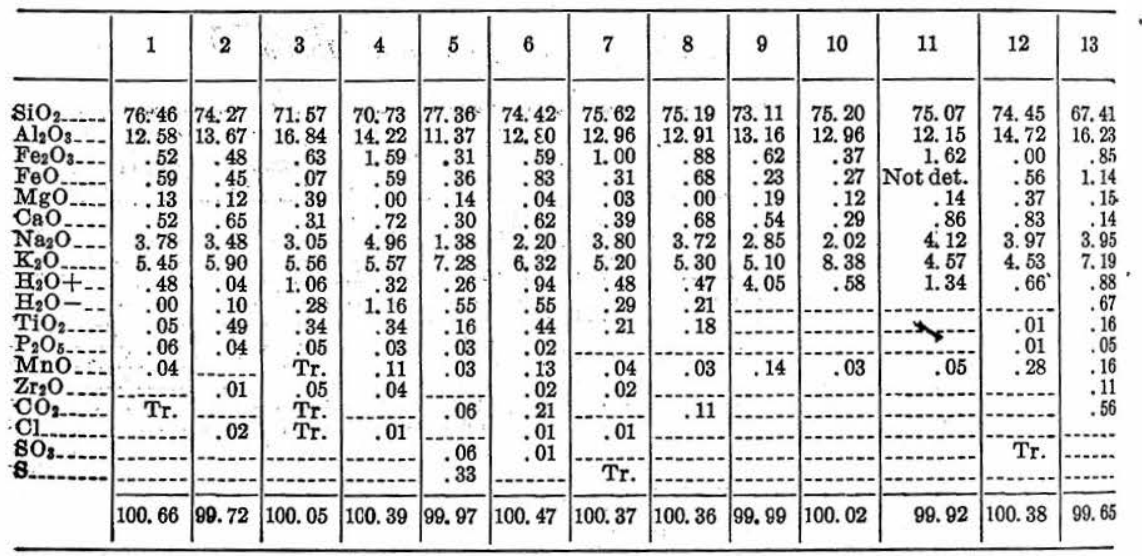

1. Granite from Treasure Mountain stock.

2. Granite stock, Brown Gulch, Monarch district. Crawford, R. D., Colorado Geol, Survey Bull. 4, p. 154, 1913.

3. Rhyolite flow, Porphyry Peak, Bonanza, Colo. Patton, H. B., Colorado Geol. Survey Bull. 9, p. 25, 1915.

4. Quartz trachyte, sills and laccoliths, Grayrock Peak, Colo. Geol. Survey Geol. Atlas, Engineer Mountain folio (no. 171), p. 10, 1910.

5-8. Larsen, E. S. personal communication.

5. Rhyolite flow, Bachelor mine, Creede, Colo. Geol: Survey Prof. Paper 99, p. 57, 1917.

6. Rhyolite, irregular intrusion, Lake Fork, San Cristobal quadrangle, Colo. Geol. Survey Prof. Paper 99, p. 123, 1917.

7. Rhyolite flow, Big Spring Gulch, San Ćristobal quadrangle, Colo. Geol. Survey Frof. Paper 99, p. 123:- 1917.

8. Granite porphyry dike, about a quarter of a mile wide, in Alpine Gulch, San Cristobal quadrangle, Colo. Geol. Survey Prof. Paper 99, p. 123, 1917.

9. Pitchstone flow, Silver Cliff; Rosita Hills, Colo. Cross, Whitman, Geol. Survey 17th Ann. Rept., pt. 2, p. 324, 1896.

10. Rhyolite flow, Silver Cliff, Rosita Hills, Colo. Cross, Whitman, Geol. Survey 17th Ann. Rept., pt. 2, p. 324, 1896.

11. Nevadite. Summit County, Colo. Lagorio, A., Min. pet. Mitt., new ser., Band 8, p. $454,1887$.

12. Nevadite stock or laccolith, Chalk Mountain, Colo. Emmons, S. F:, Geol. Survey Mon. 12 , p. $349,1886$.

13. Bostonite dike, Idaho Springs, Colo. Ball, S. H., Geol. Survey Prof. Paper 63, p. 134, 1908.

\section{MODE OF OCCURRENCE}

Form of body of intrusion.-The attitude of the beds that overlie the granite is that of a symmetrical dome, which would seem to imply a domelike form for the top of the intrusive mass that caused the uplift. The top of the stock, however, is not parallel to the dip of the overlying sedimentary rocks. This is evident on the geologic map (pl. 1), which shows that the granite has cut across more than 1,000 feet of strata and an unknown thickness of pre-Cambrian gneiss. Close parallelism between the surface of the intrusion and sedimentary rocks is limited to the top of the stock; along the sides the surface of the intrusion dips more steeply than the sedimentary rocks. 


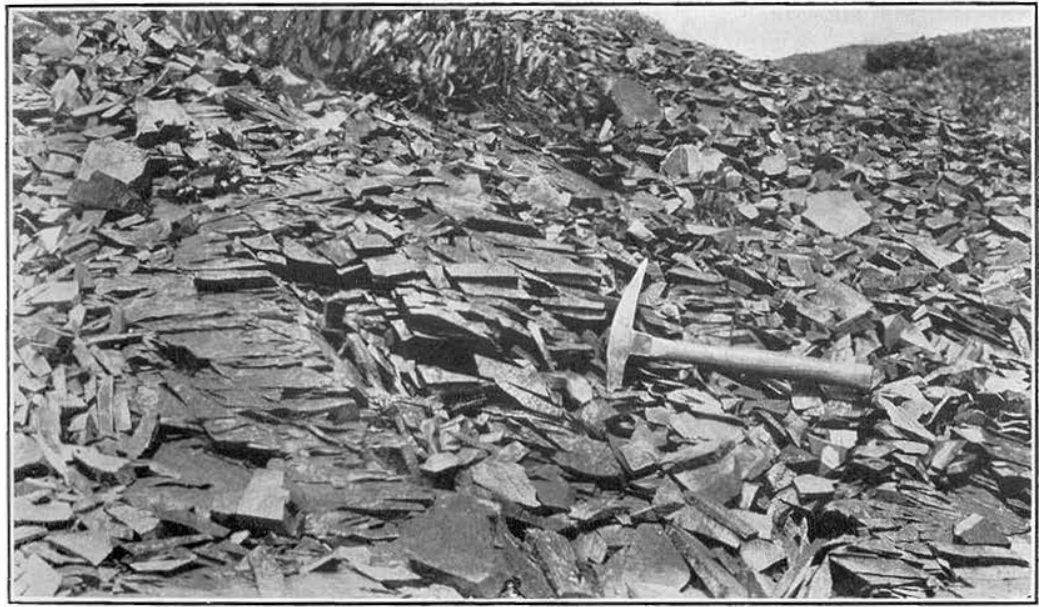

A. INDURATED MANCOS SHALE ON WEST SLOPE OF CINNAMON MOUNTAIN, SHOWING TYPICAL MODE OF DISINTEGRATION INTO BLOCKY FRAGMENTS.

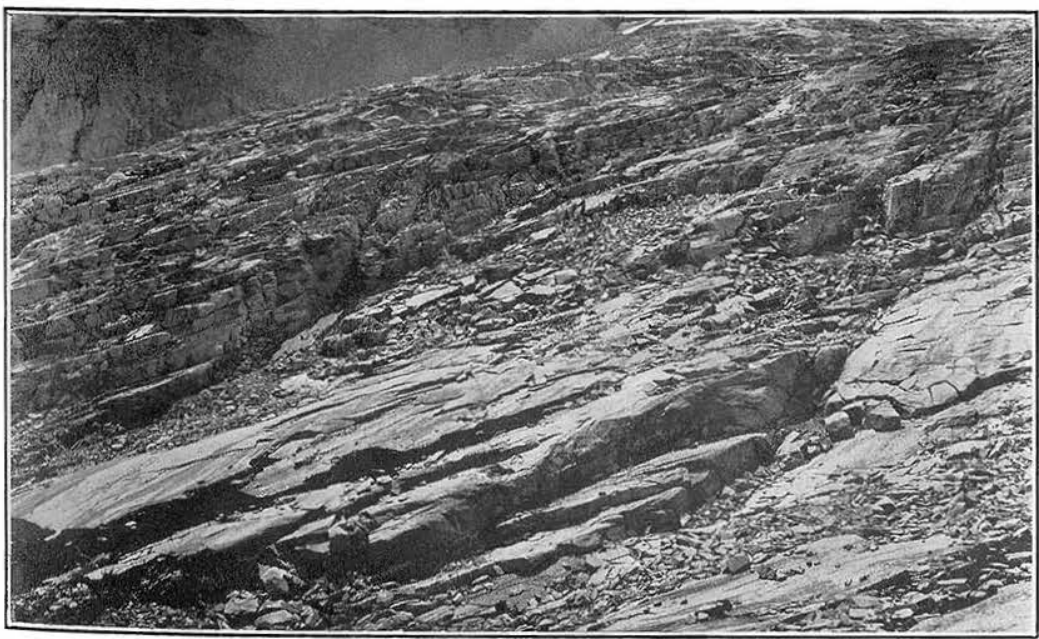

B. SHEET JOINTING IN GRANITE NEAR ITS CONTACT WITH SEDIMENTARY ROCK IN BEAR BASIN.

View looking south. Treasure Mountain stock. 


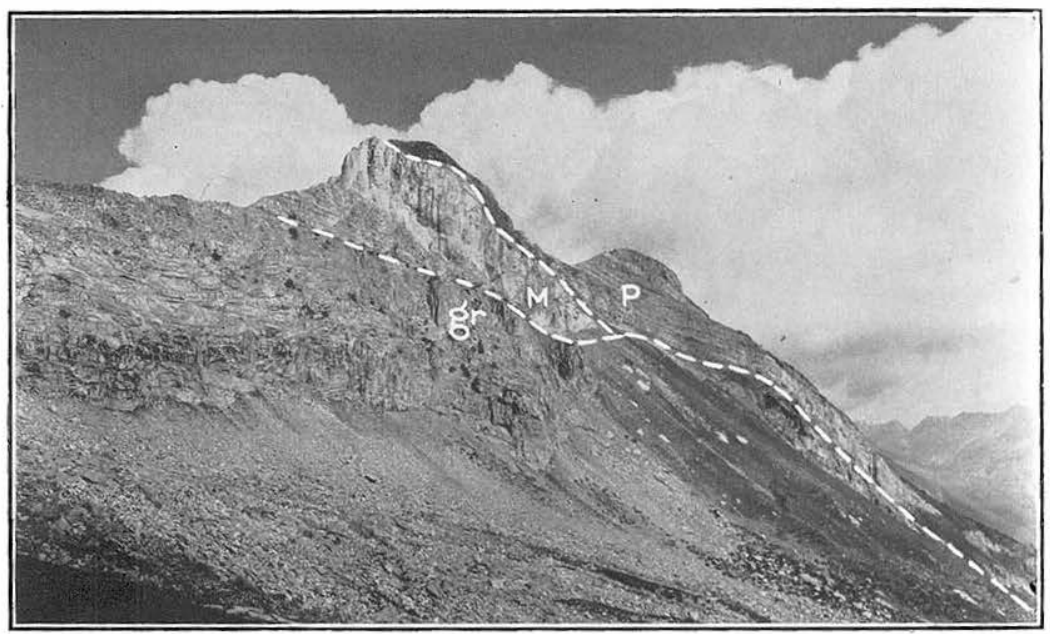

A. EAST SLOPE OF BIG BEAR MOUNTAIN SHOWING GRANITE CUTTING ACROSS THE BEDDING AT A LOW ANGLE.

gr, Granite; M, Mississippian (Leadville) limestone; P, Pennsylvanian (Hermosa (?) formation). See figure 4 .

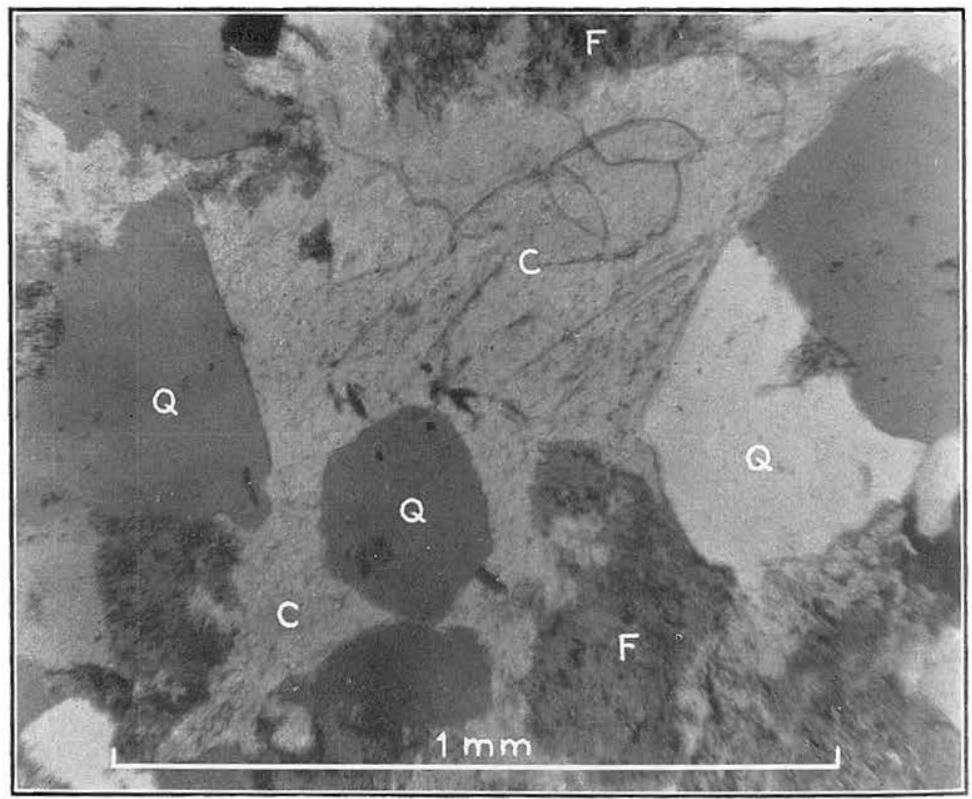

B. PHOTOMICROGRAPH SHOWING CALCITE IN GRANODIORITE OF SNOWMASS MOUNTAIN INTRUSION.

Q, Quartz; C, calcite; F, feldspar. 
Joints or sheeted zones in the granite near and parallel to the contact also express the domelike form of the intrusion. The joints are spaced 2 to 6 feet apart, and in and near the margin of the granite their parallelism, an expression of contraction of the magma, is very marked. (See pl. 7, B.) In Bear Basin the joints dip northward and the granite is in contact with sedimentary rock. On Yule Creek, where the granite is in contact with gneiss, the joints dip southward and show no tendency to parallel the structure of the gneiss.

Emplacement.-The granite came into place without violence, as is indicated by (1) complete absence of inclusions in the granite, (2) lack of crushing or crumpling along the contact, (3) scarcity of small dikelike apophyses, and (4) absence of large intrusion faults even though the intrusion raised the strata to dips of $40^{\circ}-50^{\circ}$.

The dome structure suggests a concordant intrusion, but there is also ample evidence of crosscutting. The granite is in ${ }^{*}$ contact with both gneiss and sedimentary rocks, and neither the schistosity of the
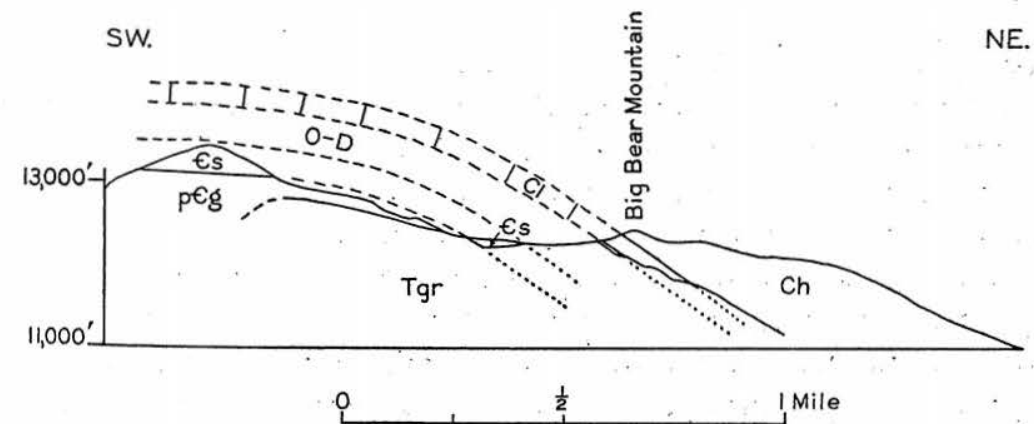

FIadRe 4.-Generalized section showing granite cutting across all the pre-Pennsylvanian formations and into pre-Cambrian gneiss. Cross section along ridge that extends north of Big Bear Mountain, shown in plate 10. Pre-Cambrian gneiss, i $€$; Cambrian quartzite, €s; Ordovician and Devonian formations, O-D; Mississippian (Leadville) limestone, Clm; Pennsylvanian (Hermosa? formation), Ch.

gneiss nor the bedding of the sedimentary rocks appears to have had much influence on the course of the advancing magma. In the area south and west of Twin Bridges (pl. 1) the granite cuts abruptly. across the bedding of the sedimentary rock for several hundred feet, but in places it cuts across the bedding at low angles, as shown on the east slope of Big Bear Mountain (pl. 8, $A$ ). North of Big Bear Mountain the granite cuts across gneiss, as shown in figure 4 . In places the surface of the contact is irregular, as shown by the small exposures of granite in gneiss on Yule Creek (see pl. 1), but elsewhere, as on the north flank of Treasure Mountain, the contact between granite and gneiss is a remarkably even curved surface. Parallelism between the contact and the schistosity of the gneiss is nowhere evident. These features do not furnish a clear picture of the conditions or the mechanics whereby emplacement was accom- 
plished. Some of the relations appear to be contradictory; for example, (1) the absence of inclusions and the presence of a chilled marginal facies can be interpreted as indicating relatively low temperatures and high viscosity of the magma, although this interpretation is hardly compatible with the presence of pegmatite and the extent of the metamorphism caused by the granite, and (2) a quiet, easy emplacement that caused little or no crushing of rocks along the contact and an intrusion moving so slowly as to permit stretching without much faulting in the process of doming are not exactly in accord with the tremendous force necessary to lift so heavy a load.

Pegmatites, aplites, and porphyritic marginal facies.-Pegmatite and aplite are found in the same general areas, and they are most abundant in places on Yule Creek and near the crest of the intrusion in Bear Basin. The porphyritic marginal phase is best developed along the Crystal River, where a thickness of more than 500 feet has been exposed; near the crest of the stock it is thin or entirely lacking. Along the Crystal River where the porphyritic facies is so well developed no pegmatite or aplite was observed. These relations suggest that the northern part of the intrusion along the Crystal River is an apophysis, probably sill-like, which permitted the chilling of the rock; the more southerly and upper part of the intrusion with pegmatites and aplites would represent the part of the magma body with deep-seated connections.

Pegmatites are uncommon in the Tertiary stocks in Colorado, even where the intrusive body is relatively large. Their common occurrence in the granite on Treasure Mountain can be explained, first, because a granitic magma is more favorable for the formation of pegmatites than magmas of intermediate composition, and second, because the part of the intrusion exposed is the top of a stock or cupola, where mineralizers would tend to concentrate.

Metamorphism.-Metamorphism of the sedimentary rocks by the granite intrusion is discussed in detail in a separate section. It is referred to here because of its obvious bearing on the nature of the intrusion. Metamorphism is not confined to the immediate contact but extends to the limits of the outcrops of Dakota (?) quartzite and slightly beyond. (See pl, 1.) The principal changes produced are recrystallization of all limestones and dolomites, production of abundant serpentine, garnet, diopside, vesuvianite, and tremolite, induration of great thicknesses of shale to hornfels, and bleaching of great thicknesses of red beds to drab gray.

Conchusions

The arched gneiss and sedimentary beds over the intrusion are suggestive of a laccolith, but a deep-seated or plutonic type of stock, possibly representing the cupola of a batholith, must be 
inferred to account for the crosscutting, the pegmatites, and the character and extent of metamorphism produced by the intrusion. Erosion has neither uncovered much of the intrusion nor cut into it deeply enough to reveal the form of more than the upper part of the stock. However, enough is exposed to show that the course of the magma was not strongly influenced by the structure of either the sedimentary rocks or the gneiss. The chilled marginal facies of the granite along the Crystal River and in the lower parts of Illinois, Chicago, and Bear Basins are believed to be related to a sill-like apophysis from the main body of the intrusion, the center of which lies to the south of Treasure Mountain, where the masses of pegmatite are common.

The conditions that prevented dikelike apophyses and permitted stretching rather than faulting of the beds as they were forced to take the form of an arch are not understood. Several factors, such as the load of overlying rock, viscosity, and rate of movement of the magma, are probably involved. The cover present at the time the magma came up seems to have been relatively thin, as only about 7,000 feet of Paleozoic and Cretaceous formations were arched by the intrusion, and if some of the early Tertiary beds now found to the west also covered the area, not more than 2,000 to 3,000 feet in thickness could be added. For additional thicknesses it would be necessary to assume that younger Eocene beds extended over the area, but even so a thickness comparable to great batholithic depths cannot be attained. If it is assumed that the inference of a relatively light load is correct and that an exceptionally high degree of viscosity is not in accord with the general granitoid textures and pegmatites present, it is necessary to postulate that the movement of the magma was very slow; otherwise faulting rather than stretching of the beds would have accompanied their uplift.

\section{RELATIVE AGE AND CORRELATION}

The Treasure Mountain stock is clearly younger than the quartz monzonite dikes correlated with the laccoliths, sills, and dikes in the Anthracite quadrangle, as these dikes have been altered by emanations that accompanied the intrusion of the stock. The relative age of the Treasure Mountain and Snowmass stocks has not been established. It has been stated that the granite of the Treasure Mountain stock is unique in the area, yet the variation in composition of the Snowmass Mountain stock suggests that the exposed part of the Treasure Mountain stock may represent a cupola or the upper part of a larger stock, which the Snowmass Mountain stock resembled before erosion had removed several thousand feet of material from its upper part. 
The Treasure Mountain stock is of Tertiary age, as the dikes and sills that it has metamorphosed are correlated with the laccoliths which cut the Eocene rocks in the Anthracite quadrangle that were mapped as Ohio Creek and Ruby formations in the AnthraciteCrested Butte folio. Several intrusive and extrusive rocks of Tertiary age in neighboring mountains in Colorado similar in composition to the granite of Treasure Mountain (see p. 48) have been described, and the possibility of their correlation naturally suggests itself; however, chemical composition alone is not a reliable basis for correlation, as pre-Cambrian rocks of similar composition are known.

\section{GRANODIORITE OF SNOWMASS MOUNTAIN STOCK}

\section{LOCATION AND ACCESS}

The grandiorite in the northern part of the area shown on plate 1 is a part of a large stock that forms several peaks, among which Snowmass Mountain and Capital Peak, a few miles north of the area, are the most prominent. The stock is in the Elk Mountains, which, except the peaks of granodiorite, do not stand conspicuously apart from the surrounding country of high relief. The granodiorite has resisted erosion to such an extent that the area of the stock forms sharp divides and high peaks and is the source or head of several streams. This rugged topography (see pl. $6, B$ ) is very characteristic and explains the general lack of roads closer than 2 to 8 miles, which makes access to the stock rather difficult. Fortunately Snowmass Mountain and vicinity lie in the Holy Cross National Forest, and the Forest Service has constructed and marked several trails across the area. These trails, together with numerous unmarked trails built by sheepmen, make many exposures of granodiorite accessible on horseback; other places of critical importance can be reached only on foot.

The easiest access to the intrusion is past Little Snowmass Lake by trail from Crystal, a ghost town which during the summer can generally be reached by automobile from Marble. Other tributaries to the Crystal River that head in the area of the intrusion and therefore afford access to it are Carbonate Creek, at Marble, and Avalanche Creek, about 18 miles north of Marble. Snowmass Mountain and Capital Peak can be reached from the north by following Capital Creek and Snowmass Creek, both of which join Roaring Fork about 15 miles west of Aspen.

\section{RELATION TO NEIGHBORING STOCKS}

The stock covers about 40 square miles and is ringed chiefly by. Maroon red beds and Cretaceous (Mancos) shale. White Rock Mountain, nearly 15 miles to the southeast, and Mount Sopris, about 
12 miles to the northwest, are intrusive stocks similar in occurrence and in the character of their rock, as pointed out by Cross in the Anthracite-Crested Butte folio. The three stocks constitute a large part of the Elk Mountains and are alined along a regional structure. Sedimentary rock completely separates each stock from the others, but their similar mode of occurrence and composition point to a common origin. A relationship between the granodiorite of Snowmass Mountain and the granite of Treasure Mountain, less than 5 miles to the south, can be theoretically inferred. The average compositions of the two are wholly unlike, but certain facies of the granodiorite suggest a differentiation which could produce a local granite facies like that of Treasure Mountain. Field evidence does not oppose such a relationship.

\section{DIFFERENT ROCK VARIETIES}

The rock of the Snowmass Mountain intrusion has not been previously described. Cross ${ }^{39}$ stated that the rock of White Rock Mountain, to the southwest, is uniform over large areas, and he also described important variations in the amounts of quartz, hornblende, biotite, and augite. He said:

In the average rock plagioclase strongly predominates over orthoclase, and biotite over hornblende. By a local increase in the amount of orthoclase, granitic facies (or modifications) are produced.

Cross does not discuss the areal distribution of the various facies, but his description is applicable to the stock of Snowmass Mountain.

The larger part of the Snowmass Mountain stock is mediumgrained and very uniform in appearance and ranges from granodiorite to quartz monzonite. It grades into fine-grained quartz diorite and albite granite in a marginal zone 150 to 1,500 feet wide along the contact. The following descriptions of the variations in texture and composition and their relations to each other are based on a detailed study of exposures within the area. This study is supplemented by studies outside the area-in the southwestern part of the stock at the head of Carbonate Creek north of Marble and in the northern part of the stock on Avalanche Creek. No attempt was made to map each variety separately, because most of the stock lies outside of the area, and, moreover, as a whole it is not related to the cycle of mineralization that deposited the economic sulphides.

\section{QUARTZ DIORITE}

Distritution.-Quartz diorite occurs in the area northeast of Little Snowmass Lake but was recognized only after study under the microscope. Farther north, east, and west quartz is megascopically more

"Cross, Whitman, Geol. Survey Geol. Atlas, Anthracite-Crested Butte folio (no. 9), 1894. 
evident in the rock, and microscopic study indicates that this is a characteristic feature of quartz monzonite and granodiorite as compared with the diorite. Further field work would be necessary to determine its distribution, but present data suggest that quartz diorite is less extensive than other varieties.

Character.-The quartz diorite is a medium-grained gray rock in which hornblende or biotite and striated feldspar are generally recognizable without a lens. The relative amounts of hornblende and biotite vary noticeably, but the total amount of ferromagnesian minerals does not vary appreciably, and the rock is uniform in appearance from place to place. Quartz is not megascopically recognizable, and its apparent absence affords about the only means by which the diorite can be tentatively identified in hand specimens. At the margin or contact and for 50 to 100 feet from it the rock is finer-grained and darker than nearer the interior, but the same mineral constituents are present.

Under the microscope the medium-grained rock shows calcic plagioclase, quartz, biotite, hornblende, a little orthoclase, magnetite, apatite, titanite, and a little chlorite. The average grain size is 0.5 to $2.0 \mathrm{mil}-$ limeters. The titanite and chlorite occur in scattered euhedral grains. The apatite tends to be associated with the magnetite and shows both euhedral an $\mathrm{l}$ anhedral forms. The magnetite is scattered and occurs as individual anhedral grains or small aggregates. The hornblende is green with pleochroism $\mathrm{X}$ pale brown, $\mathrm{Y}$ green, $\mathrm{Z}$ darker green (than Y). The biotite is brown and anhedral and varies in amount relative to hornblende. Plagioclase predominates over all the other minerals. Near the margin of the stock the plagioclase shows euhedral outlines, and zoning is well developed, as is more characteristic of a hypabyssal rock or porphyry, but away from the margin the grains are anhedral with somewhat irregular and uneven albite twinning. The average composition of the plagioclase is that of andesine $\left(A b_{55} A n_{45}\right)$, both near and away from the margin of the intrusion. Orthoclase is subordinate to quartz. The two minerals are interstitial to the plagioclase, and each constitutes not over 10 percent of the rock.

The chemical analysis below represents a specimen collected within 2 feet of the contact northeast of Little Snowmass Lake. In this area the quartz diorite is frozen to Weber (?) grits, and it is unaltered. 
Ohemical analysis of quartz diorite

[J. G. Fairchild, analyst]

\begin{tabular}{|c|c|c|}
\hline Analysis (325A) & Calculated mineral composition & \\
\hline 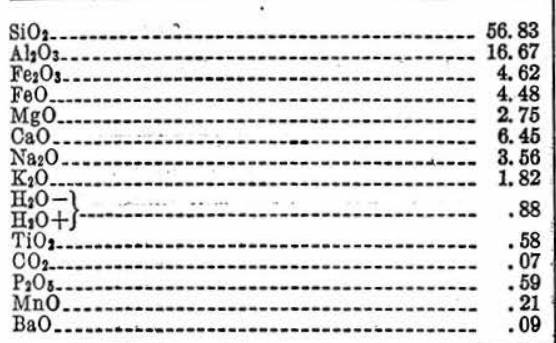 & 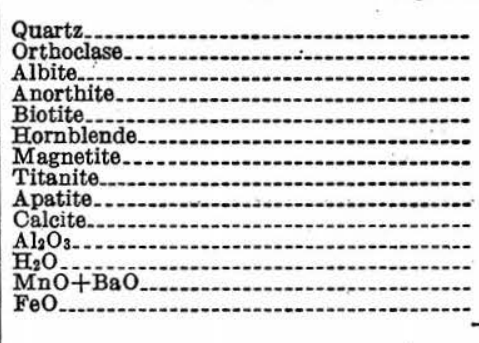 & $\begin{array}{r}14.0 \\
8.7 \\
29.9 \\
22.0 \\
23.2 \\
15.1 \\
4.1 \\
1.4 \\
1.3 \\
.2 \\
(-1.1) \\
.8 \\
.3 \\
.4\end{array}$ \\
\hline 90.60 & & \\
\hline
\end{tabular}

Nore.-Grain counts for determining mineral composition were not practicable because of the fine grain of the rock, but the mineral composition as calculated is in accord with the percentages estimated by observation.

ALBITE GRANTTE

Distribution.-Albite granite occurs continuously along the shale contact west of Little Snowmass Lake in a zone 500 to 1,000 feet wide. Both field studies and a study of thin sections show that the albite granite grades into normal granodiorite of the stock at a distance of 1,200 to 1,500 feet from the margin.

Character.-The rock appears nonporphyritic and is fine-grained and gray. In outcrop and in hand specimen it resembles the finegrained quartz diorite already described. Feldspar and ferromagnesian minerals, hornblende or biotite, are all that can be recognized with a hand lens.

Under the microscope the rock shows a completely crystalline texture with grains averaging 0.5 millimeter in diameter, and near the contact, in a zone about 150 feet wide, a porphyritic variety has developed. The minerals are quartz, sodic plagioclase, orthoclase (?), biotite, hornblende, magnetite, apatite, and titanite, with considerable calcite, some chlorite, and sericitic mica. The titanite, apatite, magnetite, hornblende, and biotite occur in about the same amount and manner as in the quartz diorite. The quartz is relatively abundant and occurs as an interstitial mineral with a smaller average grain size than the plagioclase. The plagioclase is clouded by sericitic mica and some calcite and does not have well-developed albite twinning. A low index of refraction is the chief optical property that gives a clue to the sodic composition of the feldspar. Calcite has replaced some of the hornblende and biotite and also nccurs as an interstitial mineral and as inclusions or replacements in feldspar. The chlorite ranges from almost white and nonpleochroic to pale green with perceptible pleochroism, and in several thin sections varieties with abnormal interference colors were 
observed. A chemical analysis shows the rock to contain much $\mathrm{Na}_{2} \mathrm{O}$ and very little $\mathrm{K}_{2} \mathrm{O}$ and makes it seem probable that the sericitic mica is paragonite instead of sericite, which is more generally expected in igneous rocks.

Chemical analysis of albite granite

[J. G. Fairchild, analyst]

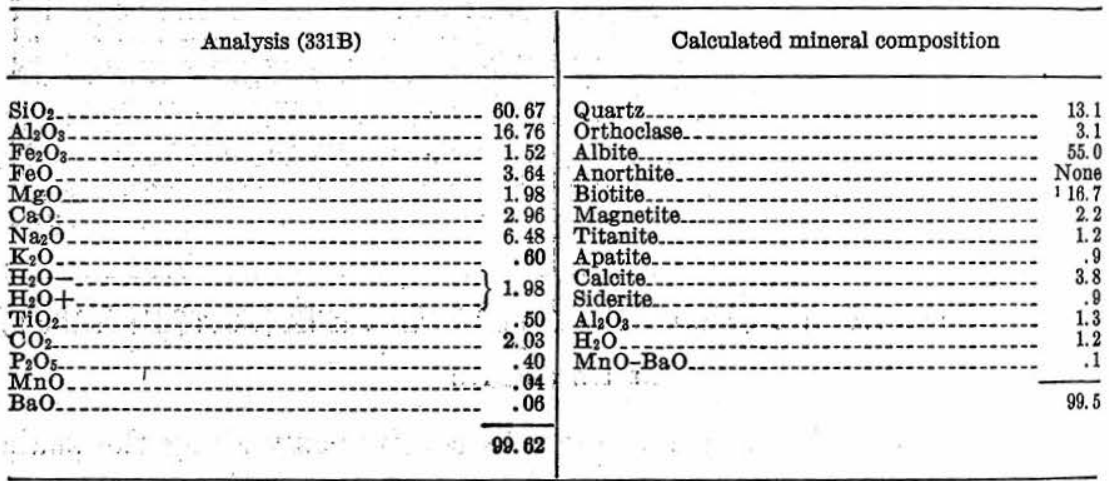

1 Unidentified fibrous brown mineral resembling biotite in color. Calculated as biotite with $\mathrm{K}_{2} \mathrm{O}$ replaoed by $\mathrm{H}_{2} \mathrm{O}$.

The albite granite was taken from the central part of a uniform zone of rock about 200 feet wide along the contact west of Little Snowmass Lake. Although there may be a considerable variation in composition from place to place in this apparently uniform zone, thin sections show that a small amount of orthoclase and a relatively large amount of calcite are characteristic of albite granite as a whole.

Alteration-Calcite, sericitic mica, and to some extent chlorite found in the sodic granite can all be regarded as indicative of alteration; but veins were not observed anywhere in the granite. Sulphides have not been found in the granite, although a little pyrite was seen in some of the inclusions of marble. The replacement of ferromagnesian minerals was accompanied by a development of calcite intergrown with a brown fibrous and platy mineral that resembles brown biotite except that it lacks high absorption. The most characteristic mode of occurrence of calcite is interstitial to the silicates in irregular forms that are never veinlike, but it also occurs disseminated in the plagioclase. The chlorite replaces both biotite and hornblende, but more commonly it occurs isolated from the ferromagnesian minerals and magnetite. The sericitic mica is disseminated through the feldspar and so far as was seen had not replaced other minerals or been deposited in them.

The presence of calcite suggests hydrothermal alteration because it is commonly found in veins and is associated with sulphides. The alteration of the albite granite, however, is not accompanied by 
the formation of the alteration products of veins, and instead of showing crosscutting relations the calcite is disseminated through the rock. I have interpreted the origin of the albite granite as due to mineralizers absorbed by the magma from the calcareous sedimentary rocks. Thus the mineralizers are secondary to the magma, but their behavior during the final stage of solidification of the magma would be analogous to that of residual primary mineralizers. The basis of these conclusions is given in the discussion of the origin of the different members of the Snowmass Mountain stock (pp. 64-67).

\section{GRANODIORITE}

Plagioclase, orthoclase, and quartz are the essential minerals throughout the bulk of the intrusion. Cross ${ }^{40}$ classified a similar rock in White Rock Mountain as diorite. Knopf ${ }^{41}$ has pointed out that the diorite of Cross would now be termed a granodiorite, and he applies this term to the rock of the White Rock Mountain stock. In the Snowmass. Mountain area the relative amount of orthoclase with respect to plagioclase varies, and accordingly the rock ranges from quartz monzonite to granodiorite, and the relative volume of these two types is not known. The term "granodiorite" is used in this report for the rock of the Snowmass Mountain stock because the rock of White Rock Mountain, which shows a similar variation in composition, has been called granodiorite.

Distribution.-Granodiorite occurs throughout the main body of the intrusion and also in the relatively narrow protrusion southward along the Elk Mountain fault. The albite granite and the quartz diorite as described are confined to a zone along the margin which is small compared to the total width of 5 or 6 miles of the intrusion. The granodiorite is exposed in many bold cliffs and steep slopes above timber line. It also forms large accumulations of talus and rock streams. All these exposures are conspicuous because of the light color of the weathered rock, which stands out in contrast with the dark green of the timber-covered slopes and the red color of the surrounding Maroon formation.

Character.-The granodiorite is a nonporphyritic gray mediumgrained rock in which quartz, feldspar, biotite, and hornblende can generally be recognized. The rock appears uniform over-large areas and differs from the quartz diorite in its relative abundance of quartz recognizable with a hand lens and the predominance of biotite over hornblende.

Under the microscope the rock is seen to be completely crystalline, with the size of the grains ranging from 0.5 to 2.0 millimeters.

\footnotetext{
${ }^{40}$ Cross, Whitman, Geol. Survey Geol. Atlas, Anthracite-Crested Butte folio (no. 9), 1894. 11 Knopf, Adolph, Recent developments in the Aspen district, Colo.: Geol. Survey Bull. 785 , p. $11,1926$.

$131028-37-5$
} 
Orthoclase, quartz, calcic plagioclase, biotite, hornblende, magnetite, apatite, and titanite were recognized, and some chlorite and sericitic mica are usually developed, but calcite may or may not be present. The titanite occurs in scattered grains more commonly anhedral than wedge-shaped. Apatite is present in small euhedral crystals scattered throughout the rock, included in the silicates, and as euhedral grains concentrated with the magnetite, which occurs in scattered areas or individual anhedral grains. Hornblende is common, although lacking in some of the thin sections. It is green with pleochroism $\mathbf{X}$ pale brown, $\mathbf{Y}$ green, $\mathbf{Z}$ darker green (than $\mathrm{Y}$ ). Typical amphibole cross sections are well developed, but the laths are always without crystal terminations. Plagioclase is euhedral and shows somewhat irregular albite twinning in combination with carlsbad twins. Indices of refraction and extinction angles indicate the average composition to be that of oligoclase $\left(\mathrm{Ab}_{75} \mathrm{An}_{25}\right)$. In some thin sections andesine $\left(\mathrm{Ab}_{50} \mathrm{An}_{50}\right)$ occurs. Brown biotite generally predominates over hornblende, and it is euhedral. Orthoclase is always present, occurring in scattered grains and in irregular interstitial areas. The amount of orthoclase varies, but in no place does it appear to exceed the plagioclase, and generally it is definitely subordinate to that mineral. Quartz is also always present and like orthoclase occurs in scattered grains and in interstitial areas.

Several representative specimens of the granodiorite were studied in thin section, and one of these, collected 1,800 feet from the contact, was selected for the chemical analysis given below under $331 \mathrm{~L}$.

Chemical analyses of granodiorite

[J. G. F'airchild, analyst]

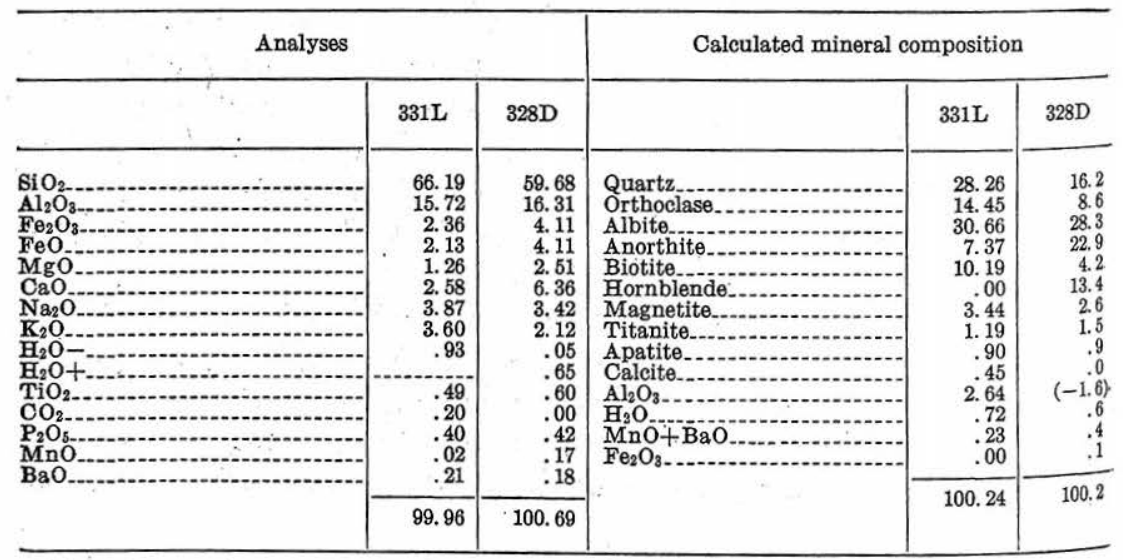

Analysis $328 \mathrm{D}$ represents a specimen collected 225 feet from the contact with the Maroon formation; this rock is really a variety of the granodiorite that is close to quartz diorite in composition. The two rocks are similar in texture and in appearance except for 
the presence of hornblende in one and biotite with more conspicuous quartz in the other. This difference is shown in the calculated mineral composition (norm), which includes only minerals actually identified in a thin section of the analyzed specimen, the albite and anorthite molecules combined representing the plagioclase. The minerals were calculated in the order in which they are shown in the table. Hornblende and biotite occur together, but more commonly only one is present. Rock showing only biotite forms the bulk of the stock.

\section{CHANGES FROM MARGIN TOWARD CENTER}

A discussion of the changes in texture and composition that occur between the margin and the center of the intrusion is given in an attempt to explain the origin of the albite granite and quartz diorite. The albite granite is contiguous to calcareous rocks, and the quartz diorite is contiguous to feldspathic rocks. Both of these rocks are confined to the fine-grained zone present along the border of the stock, and each rock grades into medium-grained granodiorite away from the margin.

The flow structure and micrographic texture related to the contact in general are also described. They are not related to the problem outlined above, and to set them apart they are grouped under structural and textural features and described first.

Structural and textural features.-A slight schistose appearance, due to hornblende and biotite oriented parallel to the contact, is common along the margin in the fine-grained rock. The best examples were found on the south slope of Snowmass Mountain. Orientation of phenocrysts in coarser-grained rock gives rise to an orthogneiss in places north of Snowmass Lake and at the head of Capital Creek, north of the area. Crushing is not evident in the finer-grained rocks that show flow structure, but some of the larger crystals, biotite in particular, show granulation in the orthogneiss. The orthegneiss has the appearance of a well-crystallized rock, but it contains fine-grained quartz and orthoclase interstitial to the plagioclase and biotite.

The rock at the margin appears nonporphyritic and differs somewhat in color and much in grain size from the rock away from the contact: In thin section, however, the marginal rock is seen to be porphyritic and shows phenocrysts of feldspar, hornblende, and biotite in a groundmass of feldspar and quartz. As a rule the texture of the groundmass is not uniform in a specimen; the grain size varies gradationally to the dimension of the phenocrysts; which accounts for the fact that the porphyritic structure is not evident in hand specimens.

Micrographic structure has a definite relation to the contact, being generally confined to a relatively narrow zone close to it. This 
structure is particularly well developed along the western border of the sill-like extension of the granodiorite south of the Crystal River. In another place the structure could be found only in a zone between the limits of 2 and 15 feet from the contact. West of Little Snowmass Lake, however, the structure was found in specimens collected 100 to 150 feet from the contact but not in specimens collected either closer to the contact or farther from it. In the coarser-grained rock micrographic structure is either absent or shows only in a very few small interstitial areas.

The apparent limitation of micrographic structure to a narrow zone near the contact suggests the possibility that it might be used as a criterion for recognizing less obvious contacts within an intrusion, but a study of the relations in other places would first be necessary because the feature may be merely characteristic of certain intrusions. As the structure is a microscopic feature and may be limited to a narrow zone it is of no practical value unless a detailed microscopic study of the rock near the contact can be made.

Changes adjacent to feldspathic beds.-Adjacent to the Maroon red beds northeast of Little Snowmass Lake the fine-grained marginal facies of the intrusion is quartz diorite. In this area a fine-grained zone about 50 feet wide is manifest, and under the microscope a porphyritic structure is evident from the margin of the fine-grained zone to a point 150 feet from the contact. At 200 feet and farther from the contact the intrusive rock has a plutonic or completely crystalline texture. Several specimens, including a series collected at $2,50,1.50,200$, and 225 feet from the contact, were examined in thin section, and chemical ang,lyses were made of the end membersspecimen 325A, collected 2 feet from the contact, and specimen 328D, collected 225 feet from the contact.

Analyses of rocks adjacent to feldspathic sandstone

[J. G. Fairchild, analyst]

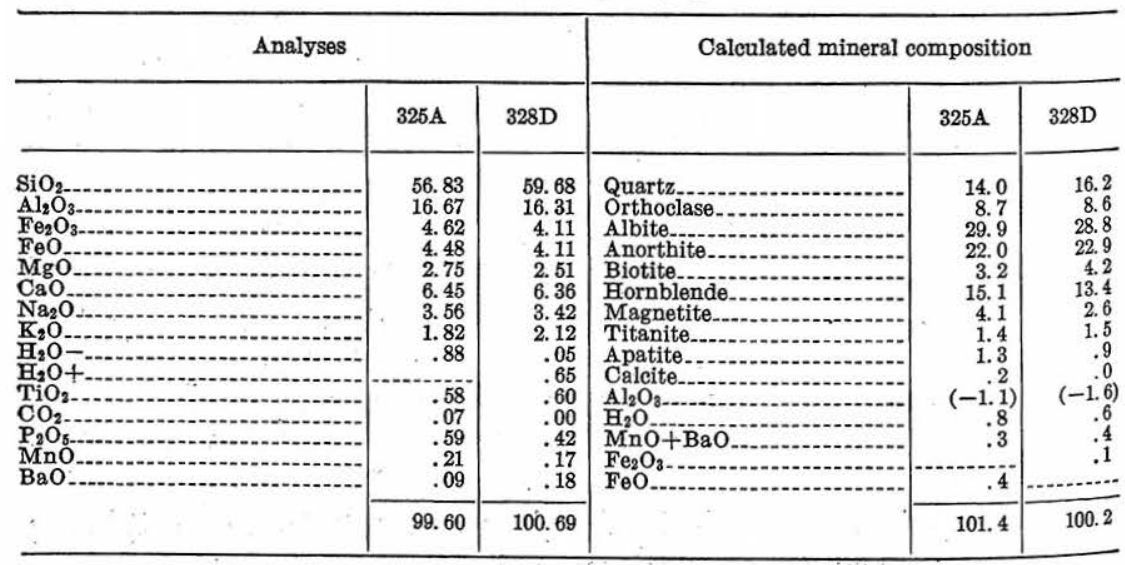


The outstanding change from the margin toward the center of the stock, as shown by the two specimens, is the increase in grain size, which is almost as marked in outcrop as it is in thin section. The rock is unaltered and in thin section shows plagioclase $\left(\mathrm{Ab}_{45} \mathbf{A n}_{55}\right)$, pale-green hornblende, brown biotite, orthoclase, quartz, magnetite, apatite, and titanite. Calcite was not recognized, although a small amount is suggested in one analysis. The chief differences observed in thin section are summarized below:

1. At the contact, represented by analysis $325 \mathrm{~A}$, the plagioclase, hornblende, and biotite crystals average about 0.1 by 0.3 millimeter, with more below than above this size, whereas 200 feet and farther from the contact the same minerals are 0.6 to 1.5 millimeters across.

2. Near the contact there is no definite groundmass. Quartz and orthoclase, about 10 percent of the whole, in grains measuring 0.03 millimeter, occupy interstitial areas. At 200 feet and more from the contact the quartz and orthoclase occur interstitially and in scattered grains nearly as large as those of the other minerals.

3. Near the contact zoning of plagioclase is characteristic, particularly in the larger grains; the smaller grains more commonly show uneven albite twinning. In the band between 50 and $\mathbf{1 5 0}$ feet from the contact the twinned grains increase in number, whereas the zoned grains show a corresponding decrease, and at a distance of 200 feet and more only the uneven albite twinning is found.

4. Titanite could not be found 2 feet or 50 feet from the contact, but it appeared in grains 0.05 to 0.1 millimeter across 150 feet and more from the contact.

5. Near the contact apatite occurs in small scattered euhedral crystals. From 150 to 200 feet from the contact the apatite in increasing amounts is associated with magnetite.

6. Flow structure occurs nearly everywhere in a zone near the contact, but the rock does not resemble the orthogneiss previously described. Orientation of biotite and hornblende can usually be seen in specimens from the zone about 50 feet from the contact, where it tends to be more evident than at the contact itself; 150 feet or more from the contact it is seldom recognizable. In some thin sections an orientation of crystals could be recognized as far as 200 to 225 feet from the contact.

Changes adjacent to calcareous beds.-Adjacent to the Cretaceous (Mancos) shale west of Little Snowmass Lake the fine-grained marginal facies of the intrusion is albite granite throughout a width of more than 1,000 feet. This wide zone of fine-grained albite granite is continuous to the west for about 5 miles. The change in texture from the margin toward the center is not a uniform change but is effected in successive zones, each maintaining a uniform texture, with gradational boundaries. For example, through a band about 100 feet wide along the contact no megascopic change could be detected, but beginning at 150 feet through a band about 10 feet wide there is a perceptible change to a slightly coarser texture. Again in the zone between 160 and 1,200 feet from the contact the lithology is uniform, but beginning at 1,200 feet through a width of about 200 feet the texture changes to that of the average of the plutonic facies of granodiorite found in the more central part of the stock. Evi- 
dence of more than one intrusion was looked for, but, although exposures were good, only gradational changes from one facies to another were found.

Inclusions of marbleized limestone ranging from a few hundred to several hundred feet across occur in the zone of fine-grained rock, and near these inclusions, whether they are close to the contact or at a distance from it, the albite granite matches in texture and appearance the rock at the contact near the shale.

A series of specimens were collected at the contact and at 100,150, 160,500 to $800,1,000,1,050,1,100,1,300$ to 1,400 , and 1,500 to 1,700 feet from the contact for microscopic study and chemical analysis. Chemical analyses were made of two representative specimens-331B, at 100 feet from the contact, and $331 \mathrm{~L}$, at 1,800 feet.

Chemical analyses of granodiorite and albite granite

[J. G. Fairchild, analyst]

\begin{tabular}{|c|c|c|c|c|c|}
\hline \multicolumn{3}{|l|}{ Analyses } & \multicolumn{3}{|c|}{ Calculated mineral compositions } \\
\hline & $331 \mathrm{~L}$ & 331B & & $331 L$ & $331 \mathrm{~B}$ \\
\hline \multirow[t]{2}{*}{ 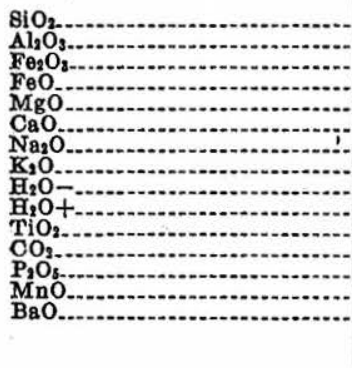 } & $\begin{array}{r}66.19 \\
15.72 \\
2.36 \\
2.13 \\
1.26 \\
2.58 \\
3.87 \\
3.60 \\
.93 \\
.49 \\
.20 \\
.40 \\
.02 \\
.21\end{array}$ & $\begin{array}{r}60.67 \\
16.76 \\
1.52 \\
3.64 \\
1.98 \\
2.96 \\
6.48 \\
.60 \\
1.98 \\
.50 \\
2.03 \\
.40 \\
.04 \\
.08\end{array}$ & \multirow[t]{2}{*}{ 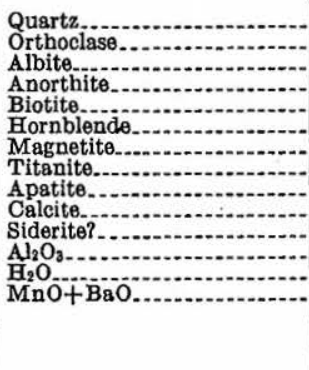 } & \begin{tabular}{r}
28.3 \\
14.5 \\
30.7 \\
7.3 \\
10.2 \\
\hdashline 3.4 \\
1.2 \\
.9 \\
.5 \\
2.6 \\
.7 \\
.2
\end{tabular} & $\begin{array}{r}13.1 \\
3.1 \\
55.0 \\
116.7 \\
2.2 \\
1.2 \\
.9 \\
3.8 \\
.9 \\
1.3 \\
1.2 \\
.1\end{array}$ \\
\hline & 99.96 & 89. 62 & & 100.5 & 89.5 \\
\hline
\end{tabular}

1 Calculated as biotite with $\mathrm{K}_{2} \mathrm{O}$ replaced by $\mathrm{H}_{2} \mathrm{O}$; mineral not identifled but resembles biotite in color.

The percentage of carbon dioxide and sodium oxide is high in the albite granite $(331 \mathrm{~B})$, and that of potash and calcium oxide in excess of the amount required to balance the carbon dioxide is very low as compared with the percentages of these oxides in the other specimen. Specimen 331L was collected to represent the normal rock of the stock and to be compared with specimen $328 \mathrm{D}$ of the other series.

A mineral count of the albite granite, because of its fine-grained texture, did not prove satisfactory. In calculating the mineral composition from the chemical analysis the titanite and apatite in $331 \mathrm{~B}$ were calculated first, and the remaining $\mathrm{CaO}$ was then calculated as $\mathrm{CaCO}_{3}$, after which the remaining $\mathrm{CO}_{2}$ was combined with $\mathrm{FeO}$ in $\mathrm{FeCO}_{3}$.

The identity of calcite observed in thin section was checked by determination of refractive index and solubility in cold dilute hydrochloric acid (1:5) of grains isolated from powdered rock. The diluto 
acid solution thus obtained gave a weak test for ferrous iron, which is the basis for believing that a ferrous carbonate molecule is present. The mica has been arbitrarily calculated because the identity of the platy or fibrous mineral, resembling brown biotite in color, is not definite; however, the average proportions of typical analyses are thought to be approximately represented in this specimen. Sericitic mica is not calculated separately, and the percentages of orthoclase as calculated may be slightly in excess of the true amount.

Each thin section shows plagioclase (albite or oligoclase) with or without orthoclase, quartz, biotite or hornblende, magnetite, apatite, and titanite. The textural differences are as great as in the series opposite the feldspathic rocks, but the differences in composition are more pronounced. The characteristic features of the specimens collected to represent the changes are summarized below:

1. At 0 to 150 feet from the contact the phenocrysts average 0.2 by 0.3 millimeter in size, but there is a noticeable change to 0.5 millimeter between 150 and 160 feet. From 160 to 1,200 feet the grain size gradually increases to 0.2 by 0.6 millimeter, with some 0.8 by 1.5 millimeters. About 1,300 feet and farther from the contact the grain size is uniform and averages about 0.5 by 1.5 millimeters. Some grains are over 2.0 millimeters across.

2. In the rock up to 100 feet from the contact about one-half of each thin section examined consists of well-defined groundmass with a grain size averaging 0.02 by 0.08 millimeter. At 150 feet there is no well-defined groundmass, and less than 10 percent of the grains are as small as 0.08 millimeter. From 160 to 1,200 feet there is no groundmass, although a small percentage of finegrained interstitial quartz and orthoclase ( 0.05 to 0.1 millimeter) occurs in each thin section. At 1,300 feet the interstitial quartz and orthoclase constitute about one-third of the rock, forming a fairly well defined groundmass, which becomes poorly defined at about 1,500 feet and is lacking beyond 1,600 feet.

3. Plagioclase predominates and shows zoning, albite twinning, and albitic rims. At the contact there is little twinning, no zoning, and no albitic rims, but at $\mathbf{1 0 0}$ feet from the contact all these features are slightly developed, and from 160 to 1,200 feet they are characteristic features of the plagioclase. At 1,300 feet the zoning and albitic rims are lacking and the albite twinning is only poorly developed, but at 1,500 feet all three are present, and at 1,800 feet they are again rather well defined, although less conspicuous than in the zone between 160 and 1,200 feet.

4. Sericitic mica is common in each thin section and interferes with identification of the plagioclase. The identification of sericite is in doubt. Paragonite instead of sericite is suggested by the chemical analysis, which showed only 0.60 percent of $\mathrm{K}_{2} \mathrm{O}$ in a rock containing an appreciable amount of the mica. The sericitic mica appears to be less abundant at a distance of 1,500 feet and more from the contact.

5. In every thin section quartz occurs in conspicuous amounts, either in the groundmass or as an interstitial mineral. It is noticeably fine-grained and subordinate to the plagioclase. The grain size of quartz increases more uniformly than that of the plagioclase. The change at 150 to 160 feet is scarcely evident, and at 1,200 feet it is not striking. The range of grain size from the contact to 1,200 feet is about 0.05 to 0.2 millimeter, and farther from the contact the range increases to 0.05 to 1.5 millimeters. 
6. Orthoclase was not recognized from the contact to 160 feet, but from 500 to 1,200 feet some occurred as an interstitial mineral. From 1,300 to 1,800 feet orthoclase appears to be more common, but as all the feldspars are more or less clouded the relative amount of orthaclase that may be present could not be determined.

7. Magnetite is common throughout except at the very contact, where it is entirely lacking. From 100 to 1,800 feet the magnetite varies slightly in amount and grain size, but the change appears to be haphazard.

8. Pale-green hornblende, generally much altered, occurs in the zone from 150 to 1,200 feet. From the contact to 100 feet there is an alteration product believed to be a hydromica, which may represent altered hornblende. From 1,300 to $1_{8} 800$ feet hornblende is lacking.

9. Brown biotite occurs in the zone from 150 to 1,800 feet and is partly altered. From 1,300 to 1,800 feet biotite is slightly altered, and some flakes are green. As with hornblende, the hydromica found from the contact to 100 feet may represent altered biotite.

10. Pale-green chlorite (penninite) is generally present, and in only a few thin sections is the alteration of biotite to chlorite evident; the chlorite commonly occurs isolated from other ferromagnesian minerals.

11. Titanite and apatite are uniformly present in small but easily recognizable amounts. The titanite is cloudy and appears altered at the contact.

12. Calcite is a common constituent but is more abundant near the contact and near inclusions than at a distance from sedimentary rocks. From the contact to 160 feet it is more abundant than from 160 to 1,200 feet, and at 1,800 feet it is present in some thin sections examined but not all, and the chemical analysis showed only 0.45 percent of calcite. The calcite near the contact replaces hornblende, biotite, and to some extent plagioclase, but its most characteristic habit both near and far from the contact is that of an interstitial mineral, as shown in the photomicrograph (pl. $8, B$ ). The calcite does not form veins, and the closest approach to vein habit seen in thin section is the occurrence of a little calcite along a few small fractures in a quartz grain. Many fractured quartz grains without calcite were observed in thin sections.

\section{ORIGIN OF ALBITE GRANITE AND OTHER ROCK VARIETIES}

The several varieties of rock found in the Snowmass Mountain stock not only have a kearing on the differentiation of a magma but also offer a possible explanation for the development, under special circumstances, of a highly albitic rock. Figure 5 shows graphically the interrelations of the variations in composition to the contact and to each other. The magma at the time of intrusion had the composition of quartz diorite, similar to that found northeast of Little Snowmass Lake. (See fig. 5, specimens 325A and 328D.) In this area the rock is unaltered and undifferentiated, as the chilled and coarser-grained rocks show the same chemical composition. Furthermore, the quartz diorite is relatively poor in potash and silica, which are abundant in the grits or wall rock, and therefore appreciable assimilation did not occur. The albite granite (331B of fig. 5), on the other hand, contains calcite, and the calcite is most abundant near the contact of calcareous shales. Inclusions of marbleized limestone 
are numerous. Obviously the albite granite does not represent the original composition of the magma.

In considering the origin of the albite granite it is important to review the following facts: (1) It has developed only where the intruding magma followed along and broke across the Elk Mountain fault zone and where magma came into contact with shale, (2) inclusions of marbleized limestone are common in the albite granite
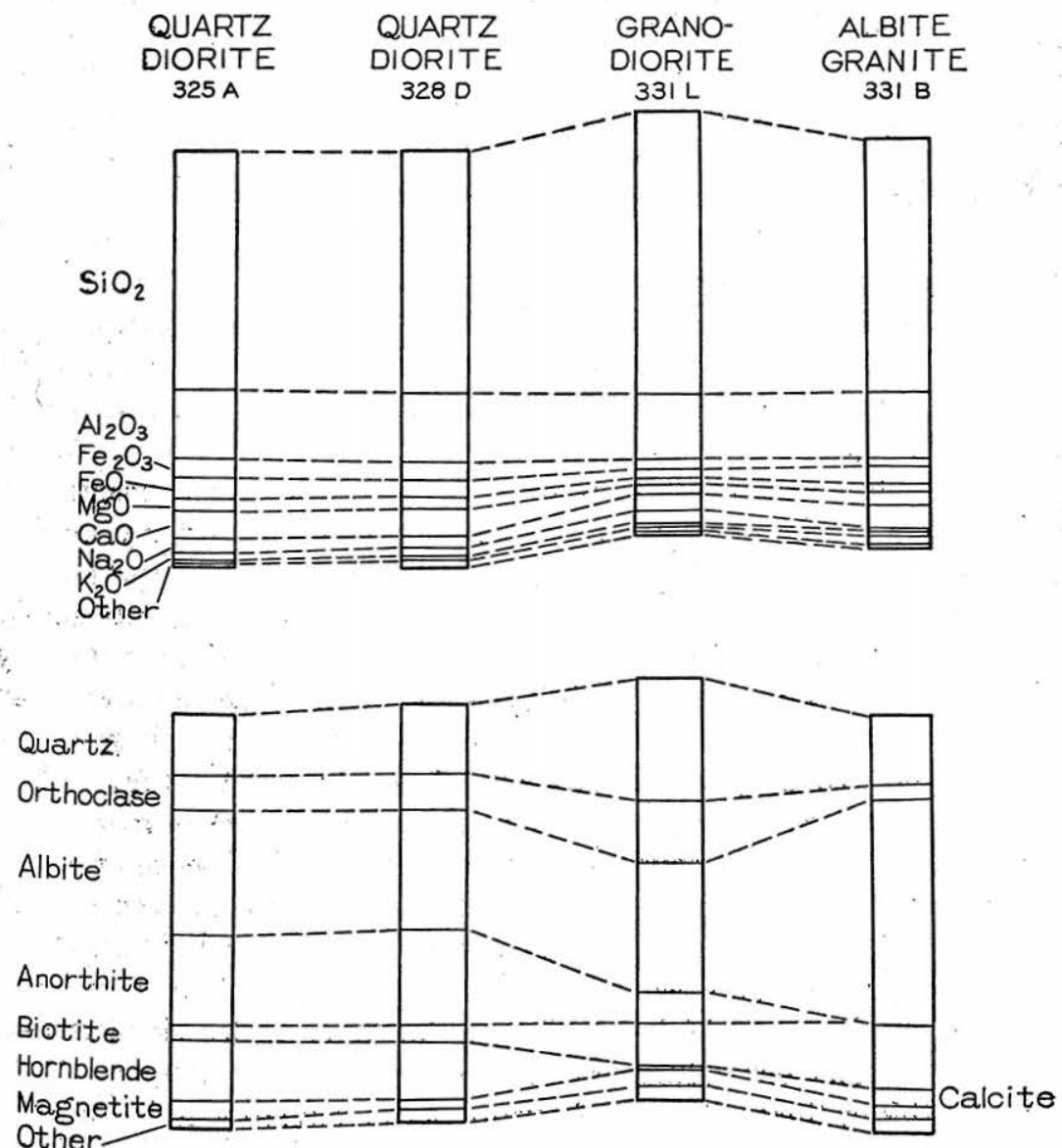

Fiaure 5.-Graphic presentation of rock varieties of Snowmass Mountain stock. 325A, Quartz diorite 2 feet from contact of feldspathic sandstone; $328 \mathrm{D}$, quartz diorite 225 feet from contact of feldspathic sandstone; 331L, granodiorite 1,800 feet from contact of calcareous rocks; $331 \mathrm{~B}$, albite granite 100 feet from contact of calcareous rocks.

zone, (3) the inclusions at a distance from the margin are surrounded by individual zones of fine-grained albitic rock, (4) calcite is most abundant near the shale contact and near the marbleized limestone inclusions, and (5) the fine-grained zone is much wider opposite the shale than it is opposite the sandstones and grits of the Maroon forration. The Elk Mountain fault zone, with its broken and 
crushed formations, furnished the inclusions found in the magma. The uniform contents of silica, alumina, titanium, and phosphate shown in the chemical analyses argue against assimilation or solution of the rock as a whole, but the presence and distribution of so large an amount of calcite can best be explained through absorption by the magma of carbon dioxide, either alone or in the form of calcite, from the sedimentary rock.

Calcite is so characteristic a mineral of veins that where it is present in an igneous rock it is generally regarded as a secondary mineral and a product of hydrothermal alteration. The calcite in the albite granite occurs like sericite in small particles in feldspar, in places it is disseminated through hornblende and biotite, and it is interstitial to quartz and orthoclase like a primary mineral. Crosscutting veins of calcite were not seen in the field nor observed under the microscope. These features, together with the uniform texture and appearance of the albite granite, do not seem compatible with hydrothermal alteration in the ordinary sense- that is, alteration by circulating solutions that effect replacement, concentration of certain constituents, and leaching of others.

The development of albite granite is the result of a concentration of the soda at the expense of potash and lime without any marked variation in the amounts of other constituents except in the relative amount of ferrous to ferric iron. These changes are totally unlike those associated with ordinary hydrothermal alterations, and they have led me to the conclusion that the albitic magma was formed by gaseous transfer of material by volatile substances, including carbon dioxide and probably water, absorbed from the sedimentary rock.

The abundance of calcite in the albite granite in proportion to the proximity of calcareous rocks and the complete absence of calcite elsewhere afford strong evidence that carbon dioxide was derived from an outside source, and under the circumstances it is a natural supposition that water was absorbed also. Obviously residual primary mineralizers could have effected the changes described if they occurred in sufficient volume and concentration in the magma. However, in the ordinary course of events, as presumably it is the crystallization of a magma that causes the concentration of mineralizers, effective concentrations occur late rather than early, and the resulting differentiation or alteration, whether albitization or sulphide mineralization, is a late magmatic phenomenon that commonly affects the intruded rocks as well as solidified parts of the intrusion.

The existence of an albite granite magma is supported by evidence outside of the area. Albite-alaskite porphyry and albite-aplite porphyry dikes and sills of Tertiary age in the Aspen district are de- 
scribed by Knopf. ${ }^{42}$ These rocks are unique among Tertiary igneous rocks of the State that have been described, and they occur not far from the granodiorite stock of White Rock Mountain. A genetic relationship between the albite rocks described by Knopf and the albite granite facies of the granodiorite of Snowmass Mountain is naturally suggested.

To summarize briefly, the origin of the albite granite that seems most reasonable to me is as follows: The magma invaded a fault zone where the calcareous rocks were present in a broken condition, permitting ready absorption of the volatile constituents, such as carbon dioxide and water, which then became a part of the magma. Prior to and during crystallization of the magma these volatile constituents acted as mineralizers. Potash and calcium were removed, probably because the orthoclase and anorthite molecules were not stable under prevailing conditions, but the albite molecule, being stable, formed in abundance. The same method of reasoning indicates that the calcite molecule was stable, as it formed rather than anorthite. A greater stability of albite as compared with orthoclase and anorthite molecules in the presence of mineralizers is in accord with albitization in pegmatites and other rocks and also agrees with the conclusions of Bowen, ${ }^{48}$ as well as others, in regard to the relative instability of the calcic plagioclase molecules. An abundance of calcite in areas where calcareous sedimentary rocks occur and an impoverishment of anorthite in the same areas are facts for which there is but one logical explanation-namely, Daly's theory of limestone syntexis. ${ }^{44}$ In my opinion the evidence is so conclusive that much of the burden of disbelief must be borne by the skeptic. An outside source of mineralizers in no way minimizes the role of residual primary mineralizers of a magma, but it can account for a larger concentration of mineralizers at an early magmatic stage than would be expected if only primary mineralizers were available. The presence of carbon dioxide does not prove it to be an essential mineralizer; the volume of the volatile constituents, as well as their composition, must be taken into account. It is not unreasonable to imagine that the formation of albitic magma by a gaseous transfer of materials could proceed as readily as albitization and transfer of material by hydrothermal solutions. Thus the development of the albite granite resulted from normal physical chemical reactions that were made possible by a particular and somewhat unusual combination of circumstances.

\footnotetext{
${ }^{4}$ Knopf, Adolph. Recent developments in the Aspen district, Colo. : Geol. Survey Bull. 785 , pp. 8-10, 1926.

${ }^{4}$ Bowen, N. L., The broader story of magmatic differentiation, briefly told: Ore deposits of the Western States (Lindgren volume), p. 114, Am. Inst. Min. Met. Eng.; 1933.

u Daly, R. A., Igneous rocks and thelr origin, pp. 430-434, McGraw-Hill Book Co., 1914.
} 


\section{MODE OF OCCURRENCE}

The Snowmass Mountain stock is rectangular in outline. It is 6 to $81 / 2$ miles across from east to west and 4 to 6 miles from north to south. The boundary within the limits of the Snowmass Mountain area is irregular, owing to the southward extension of granodiorite along a thrust-fault surface. The western part of the contact and the entire boundary outside the limits of the area are very regular and as a whole stand out in contrast with the very irregular ground plan of the White Rock Mountain stock, to the southeast, as described by Cross. ${ }^{45}$

The contact is well exposed high on the steeper slopes but elsewhere is generally obscured by surface cover produced by weathering. On the north and east sides of the stock the Permian grits dip away from the granodiorite, and the structure resembles that of a concordant intrusion; however, the intrusion cuts across the bedding in most places. East of Snowmass Mountain the bedding dips about $55^{\circ}$ E., but the contact dips $65^{\circ}$ to $75^{\circ}$. (See pl. 9.) South of Snowmass Mountain and at the north end of the neck of the long south extension of granodiorite the contact is well exposed and shows the sedimentary beds folded to vertical and overturned positions by the intrusion. (See pl. 10, A.) South of this fold (to the right in pl. $10, A)$ the outline of the contact is irregular because it dips to the south at a low angle, and it is exposed on an uneven erosion surface. The tongue of granodiorite that crosses the Crystal River apparently did not extend upward as high as the more central part of the stock and apparently represents a small apophysis intruded along the thrust-fault surface.

The contact north and west of Little Snowmass Lake, controlled by the Elk Mountain fault zone, is essentially vertical and crosses the strike of the Maroon formation. The Maroon is distorted and crushed, and its stratification has been obliterated throughout a zone several hundred feet wide. Farther west the contact along the shale is also nearly vertical and cuts across the bedding where exposed in Lost Trail and Silver Creeks. Along the contact the shale is crushed, and its stratification is not evident throughout a zone 500 to 1,000 feet wide, but beyond this the shale dips to the north, or toward the intrusion.

The intrusion of the granodiorite was accompanied by a bleaching of the red grits (Maroon) to a gray rock, and a little scattered epidote and garnet were formed. In a few places there are small concentrations of magnetite in the sedimentary rocks within the contact zone. This relatively weak metamorphism is in striking contrast to the strong alteration around the relatively small granite

¿5 Cross, Whitman, op. cit. (Folio 9). 
intrusion of Treasure Mountain. The White Rock Mountain stock, nearly equal in size to the Snowmass Mountain stock, was the cause of pronounced metamorphism. Strong metamorphism around the granite of Treasure Mountain is in accord with the inference that the exposures represent the roof of the stock, where metamorphic effects would be greatest. Conversely, the relatively weak effects of metamorphism around the Snowmass Mountain stock are believed to represent rock alteration well below the top and on the flanks of the stock, where the concentration of rising emanations and therefore the degree of alteration would be less.

\section{CORRELATION}

The granodiorite cuts a quartz monzonite dike resembling the Lincoln porphyry and therefore, like the granite of Treasure Mountain, is later than the dikes. Direct evidence of the relative ages of the granodiorite and the granite is lacking, but indirect evidence suggests a possible genetic relationship. The soda-potash granite of Treasure Mountain is more like that of the granodiorite than that of the albite granite, and it could be a product of differentiation of a quartz diorite magma.

Snowmass Mountain, White Rock Mountain, and Mount Sopris are composed of the same kind of rock, and they are intruded close together along a fault zone; both points of similarity suggest very strongly that they belong to a single center of intrusion. Granodiorite similar in mineral composition to the stocks of the Elk Mountains is not common in any of the commercially important mineralized districts in Colorado, but this fact does not prove that the composition of the undifferentiated magmas was dissimilar. Had the different varieties of the Snowmass Mountain stock occurred as dikes, sills, or even stocks they could not be readily correlated on the basis of lithology with rock found in the parent stock.

In discussing the origin of the albite granite a genetic relationship with albite-alaskite porphyry and albite-aplite porphyry rocks of the Aspen district was suggested. The sequence of intrusion and faulting in the. Aspen district given by Knopf ${ }^{46}$ does not wholly support and at the same time does not necessarily vitiate a genetic relationship between the albitic rock of the Aspen district and the granodiorite intrusions of the Elk Mountains. Further studies would be justified to test, if possible, the validity of such a correlation.

Field data are scattered and relationships obscure, but it may develop eventually that the intrusions of the Elk Mountains, Treasure Mountain, and the West Elk Mountains can be referred to the same general eruptive period. Cross ${ }^{47}$ held in 1894 that such a rela-

${ }^{48}$ Knopf, Adolph, op. cit. (Bull. 785), p. 13.

${ }^{47}$ Cross, Whitman, op. cit. (Folio 9). 
tionship is reasonable for the laccolithic intrusions and dike rocks of the Ruby Range in the Anthracite quadrangle (West Elk Mountains). The variations in composition throughout this area, according to published reports, are no greater than those in the stock of Snowmass Mountain.

\section{CONTACT METAMORPHISM}

\section{GENERAI FEATURES}

Contact metamorphism is an outstanding feature of the granite stock of Treasure Mountain and in comparison is insignificant around the granodiorite stock of Snowmass Mountain. The difference mays be due to differences in the composition of the magmas, but it may also be an expression of the particular part of the stock that is exposed. Treasure Mountain is the top of a stock, where metamorphic processes would be more concentrated and more intense than down along the flanks of a stock, as represented by Snowmass Mountain.

Metamorphism related to the stock of granodiorite is confined to a zone rarely over 100 feet wide along the contact, and at no place are the changes as thorough or as intense as on Treasure Mountain. The changes most commonly evident are the bleaching of some of the red beds, the development of small amounts of epidote, garnet, and diopside, chiefly in limestone pebbles in the Maroon grits, and the local concentration of small amounts of magnetite. The magnetite bodies are too small and too erratic in their occurrence to be of economic importance, and as sulphide mineralization has not occurred in the granodiorite its contact metamorphism will not be considered further.

Contact metamorphism on Treasure Mountain is described in some detail because it has a bearing on the search for ore, it caused the formation of the marble that constitutes the most important economic product in the area, and it is of scientific interest in that it represents metamorphism of an isolated intrusion that has not been complicated by subsequent changes. The relation of contact metamorphism to marble is obvious, and its bearing on the search for ore lies in the fact that without a proper understanding of it an accurate correlation of stratigraphic horizons cannot be hoped for; moreover, it is possible to mistake economically unimportant results of metamorphic alteration for indications of sulphide mineralization.

On Treasure Mountain all the sedimentary formations within the encircling outcrop of Dakota (?) quartzite are highly metamorphosed. Where the rim of quartzite is intersected and broken by faults, especially to the southeast, notable alteration of Mancos shale 
has occurred. Elsewhere this shale is relatively unchanged except for a slight amount of induration, which has left it a little more resistant to the processes of weathering. The shale of the Morrison formation (Jurassic), on the other hand, even though its distance from the intrusion ranges from less than 1,000 feet to more than 10,000 feet, is uniformly metamorphosed everywhere around the intrusion to a greenish-gray hornfels. Likewise the recrystallization of the Mississippian (Leadville) limestone to white marble and changes in other sedimentary formations are everywhere remarkably uniform. The uniform alteration of the beds below the $\mathrm{Da}$ kota (?) quartzite and the lack of changes above it suggest that the quartzite acted effectively in limiting the extent of metamorphism. This tendency of a quartzite to limit metamorphic processes has not been previously described, but it is not unique. A similar relation is suggested in places in New Mexico, as in the Santa Rita district. ${ }^{48}$

Although the effects of metamorphism are so extensive as to have a regional aspect, the silicates developed are those commonly formed by contact metamorphism. Other outstanding features are the changes that are so characteristic of certain formations that they are distinct aids in correlation. The control of the composition of the rock over metamorphism is so marked as to suggest that the original elements of the rocks combined to form most of the contact minerals without the aid of introduced materials.

Before considering this conclusion further the evidence that supports it will be given in a detailed description of the contact metamorphism in the different kinds of rock. It is intended that this plan of treatment will bring out the metamorphic features that are useful to the prospector in correlating particular stratigraphic horizons.

\section{PRE-CAMBRIAN GNEISS}

Over most of the area of exposed gneiss no alteration of any kind was observed. At the very crest of the dome the gneiss is stained conspicuously red to yellow with the oxides of iron. An examination revealed a small amount of pyrite but nothing else to suggest metamorphism. The pyrite is apparently disseminated uniformly through the gneiss and is not abundant. Thin sections show some indication of granulation or shearing of the rock, but otherwise quartz and feldspar were unchanged. Unaltered biotite is present, but the localization of limonite and pyrite suggests alteration of a part of the mica. The pyrite may be related to the sulphide mineralization, which was later than contact metamorphism. However, some pyrite is commonly associated with the serpentine, and its true relation to metamorphism is not certain.

\footnotetext{
spencer, A. C., personal communication.
} 


\section{DIKES AND SILLS}

The gabbro porphyry is least affected; it shows spots and occasional veinlets of calcite only a few millimeters across; otherwise it appears unaltered. In thin section, although the feldspar is fresh or only slightly sericitized, the ferromagnesian minerals are seen to be partly or completely replaced by combinations of calcite, chlorite, and magnetite. Locally both the primary and secondary magnetite are replaced by a mineral resembling leucoxene. In the more calcic rock, in which ferromagnesian minerals are plentiful, the chlorite is a very pale green, essentially nonpleochroic mineral with a low birefringence, suggesting a composition close to that of antigorite. It is not closely associated with magnetite, but instead it forms rims around the areas composed of calcite and quartz. In the quartz monzonite and lamprophyric rock the chlorite is penninite, which with associated magnetite replaces both biotite and augite. In most specimens replacement is complete, and except for a few remnants. the identity of the primary mineral could not be ascertained. The feldspar and magnetite in quartz monzonite and lamprophyric rock, as in the gabbro, generally contain sericite and some calcite.

At the head of Rock Creek, within the zone faults, where metamorphism has been rather intense, the dikes and sills contain augite, black tourmaline, garnet (andradite), diopside, green hornblende, and epidote. Tourmaline occurs in small massive nodules, diopside and green hornblende as scattered crystals, and epidote as both scattered grains and veins. Brown to resinous garnet, some of which shows zoning and birefringence, and dark-green to black augite are most abundant and locally occur in small stringers or masses of irregular form that completely replace the rock.

\section{SHALE}

The Mancos shale, which overlies the Dakota(?) quartzite, is less altered than the shale below the quartzite. Above the quartzite the bedding planes of the shale are preserved, and its black color has. been little affected, except locally. Along the fault zone in the southern part of the Treasure Mountain dome the shales are changed to a flinty hornfelsic rock sufficiently firm to serve as a surfacing for the road near Emerald Lake, whereas the unaltered Mancos shale is famed for its readiness to weather to clay that forms almost impassable sticky, muddy roads when wet. On Baldy and Cinnamon Mountains the Mancos shale is iron-stained from the weathering of pyrite, and it therefore appears much more altered than it really. is. As pyrite is common everywhere through the Mancos shale its. presence in this area cannot be definitely ascribed to contact meta- 


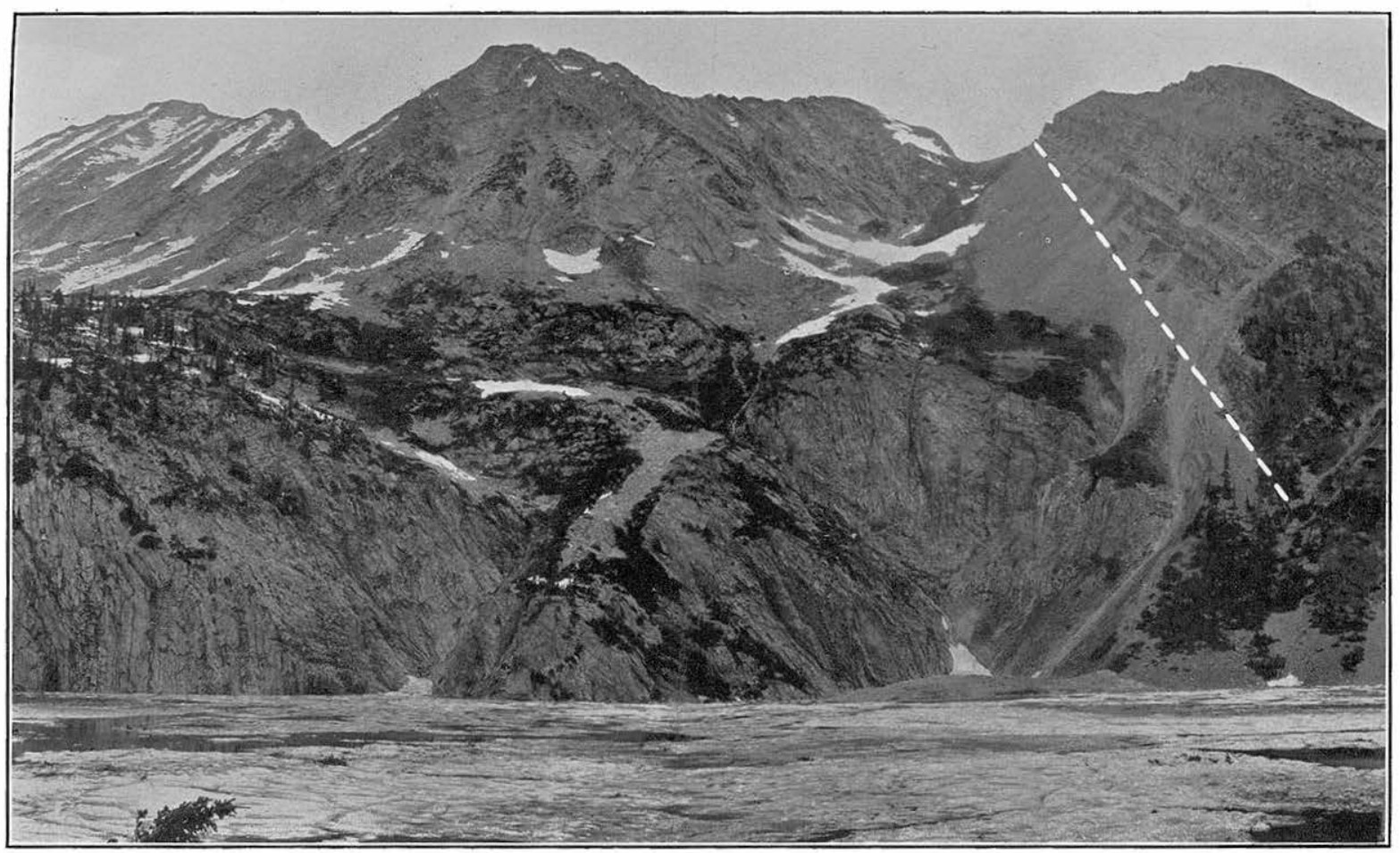

CONTACT OF GRANODIORITE OF SNOWMASS MOUNTAIN INTRUSION AND MAROON GRITS NORTH OF SNOWMASS LAKE. Beds dip about $55^{\circ} \mathrm{E}$. and the contact $65^{\circ}-75^{\circ} \mathrm{E}$. 


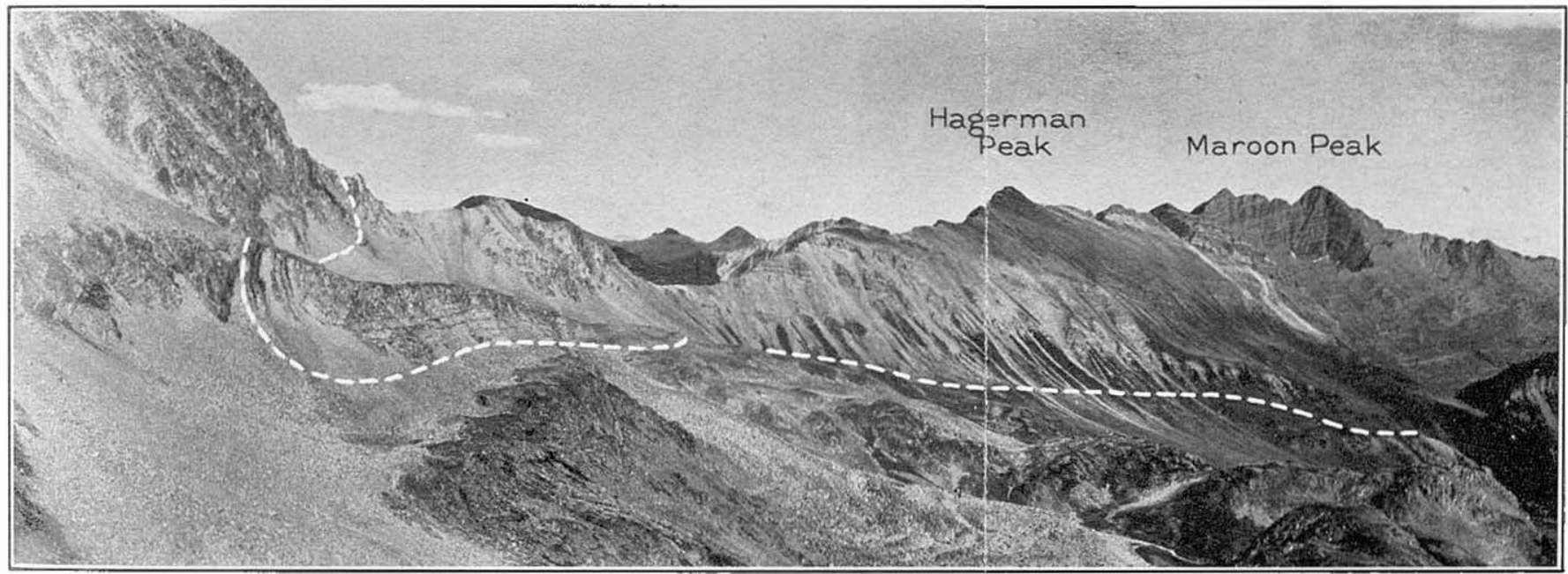

A. CONTACT OF GRANODIORITE OF SNOWMASS MOUNTAIN INTRUSION AND MAROON GRITS SOUTHWEST OF SNOWMASS LAKE. View from west. Snowmass Lake lies beyond low saddle to left of Hagerman Peak.

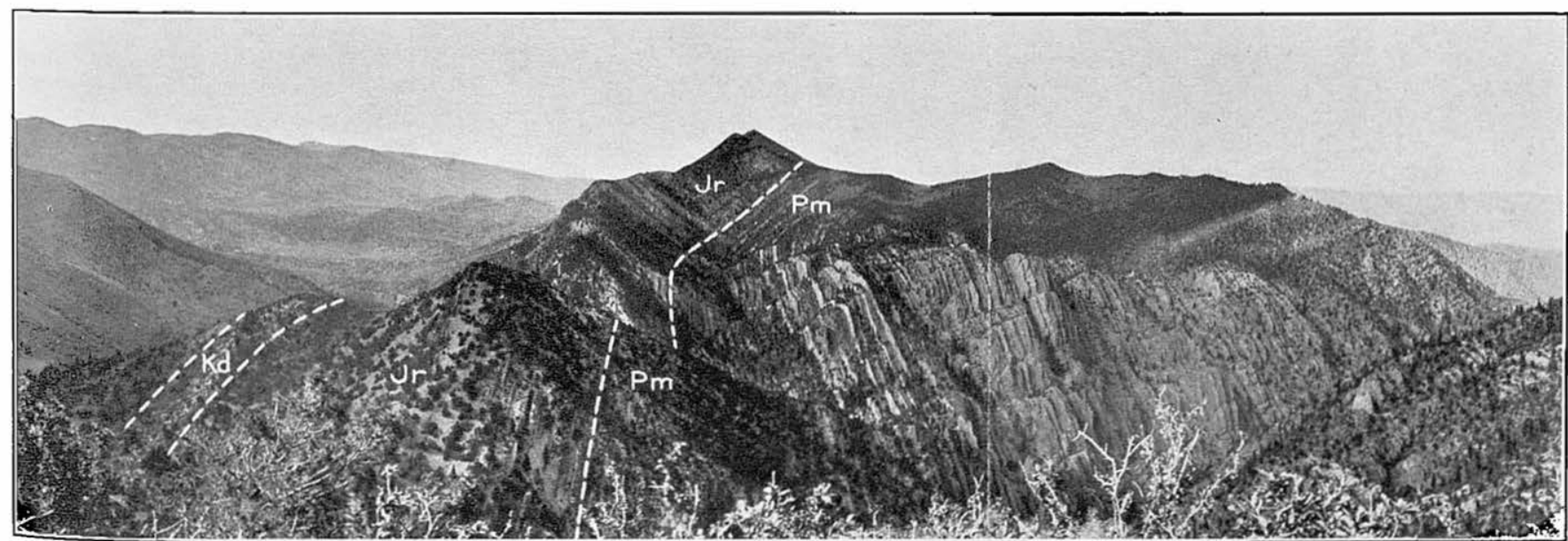

B. VIEW ALONG NORTHWARD CONTINUATION OF ELK MOUNTAIN FAULT ZONE ON THOMPSON CREEK ABOUT I5 MILES NORTHWEST OF MARBLE.

Vertical beds. Kd, Dakota (?) quartzite; Jr, Jurassic rocks; Pm, Maroon red beds. Longitudinal valley on left is in Mancos shale. 


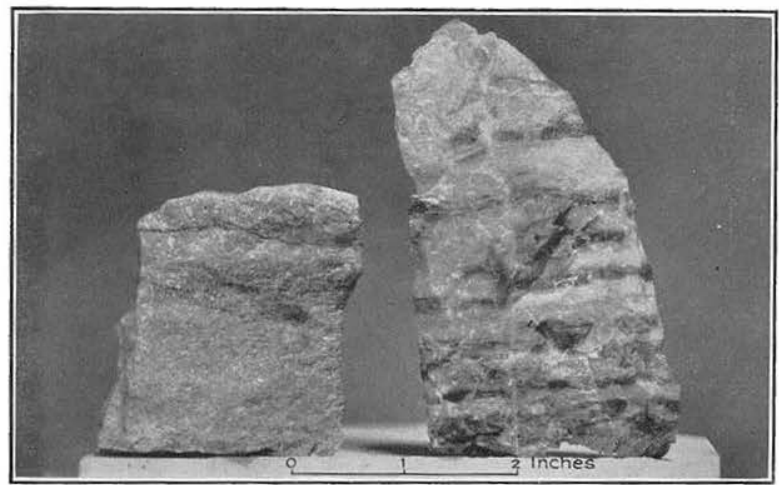

A. BANDED SERPENTINIZED MANITOU (ORDOVICIAN) DOLOMITE.

Dark bands are serpentine and light bands are carbonate.

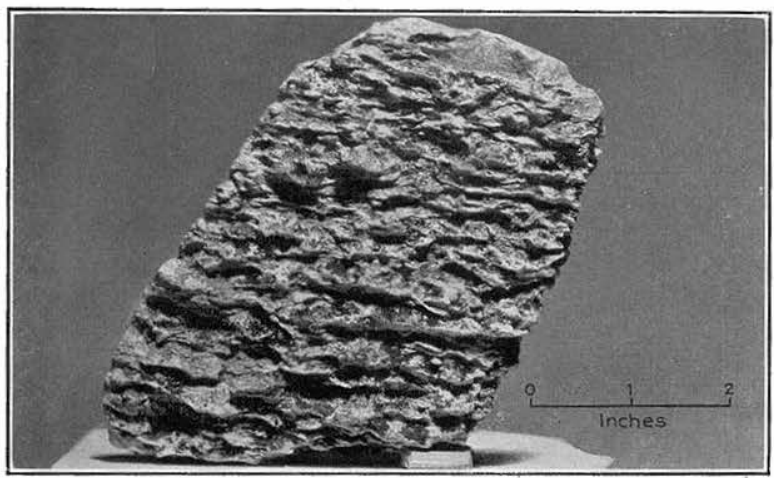

B. RIBBED PATTERN PRODUCED BY WEATHERING OF METAMORPHOSED DYER (DEVONIAN) DOLOMITE CONTAINING IRREGULAR BANDS OF DIOPSIDE.

The ribs are dolomite and the depressions between are calcite with diopside.

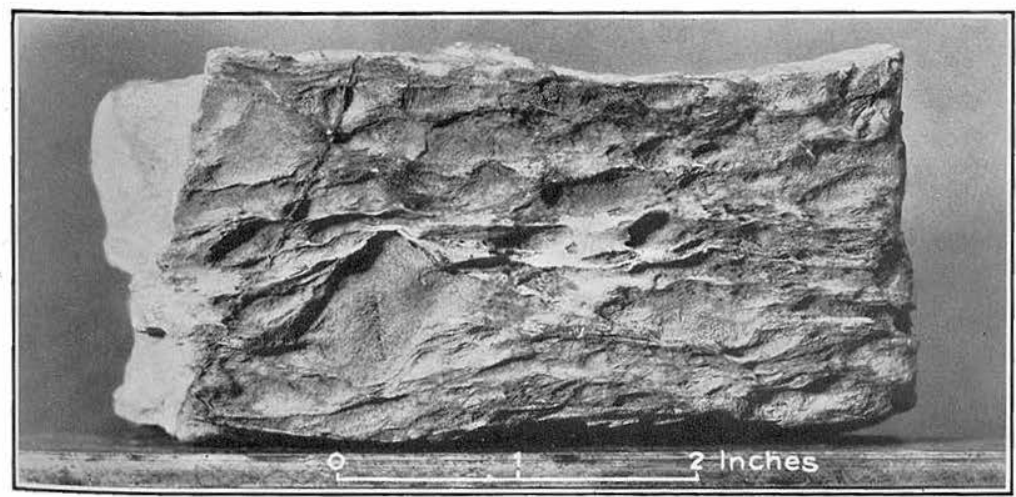

C. RIBBED PATTERN PRODUCED BY WEATHERING OF UNALTERED DYER (DEVONIAN) DOLOMITE FROM THE ALMA DISTRICT, PARK COUNTY, COLORADO.

Ribs are siliceous and depressions are dolomite. 


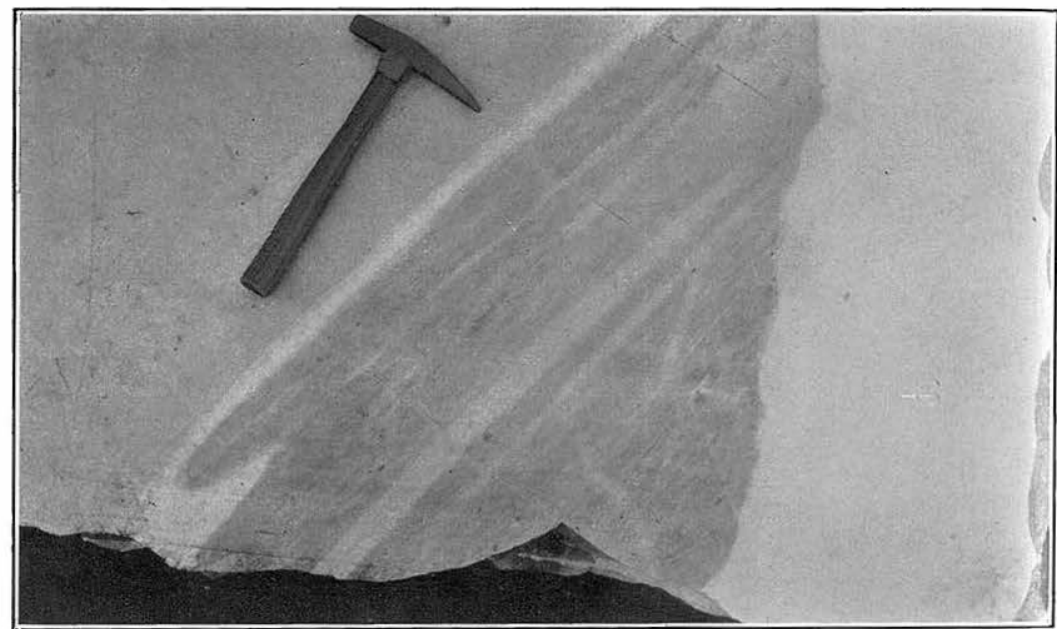

A. MARBLEIZED DOLOMITIC LIMESTONE IN MISSISSIPPIAN (LEADVILLE) LIMESTONE ENCOUNTERED IN THE YULE COLORADO MARBLE QUARRY.

Gray patches contain partly recrystallized dolomite.

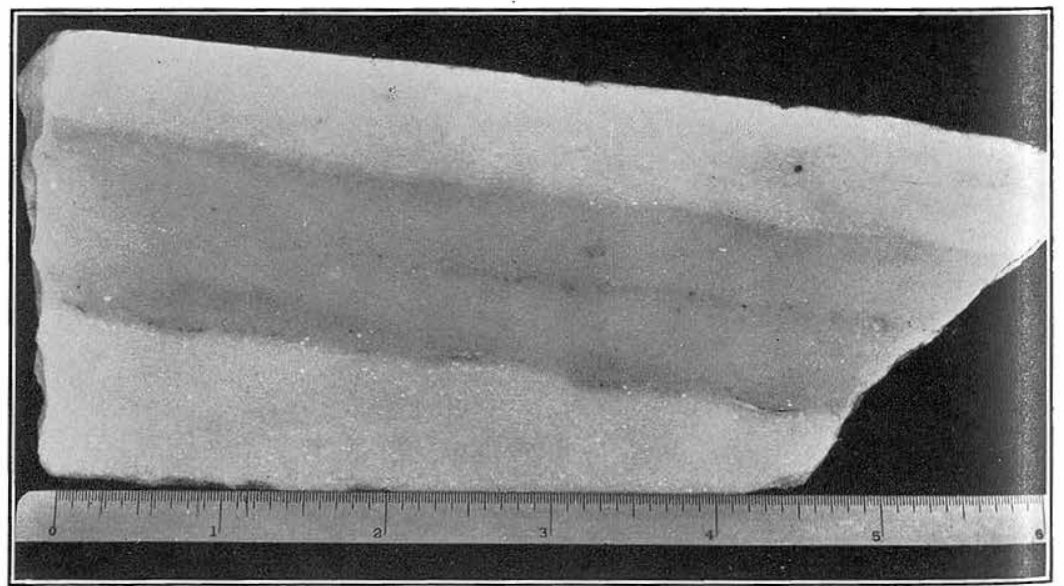

B. SILICIFIED (LIME) AREA IN MISSISSIPPIAN (LEADVILLE) LIMESTONE. Gray band consists of quartz with inclusions of diopside (?). Black spots are pyrite. 
morphism, although such an origin is suggested by its relative abundance.

All the shales below the Dakota(?) quartzite have been altered to hornfels, a dense flinty rock that breaks into irregular angular fragments. The color of the hornfels is invariably gray, usually a light, shade, with a distinct greenish tint and without a trace of the original color. Hornfels from the Morrison (Jurassic) shales has a more characteristic green color than other hornfels, and this color is an aid in recognizing the Morrison horizon. From a distance the green color is not apparent, and the hornfels appears as a light to drabgray rock.

Bedding planes have been entirely obliterated in most of the shales that do not contain sandy or limy partings. In the Cambrian and Pennsylvanian shales the effect of thin sandy and limy beds, further described under the heading "Sandy shale and shaly limestone", has been to preserve the bedding of the formations as a whole but not of individual strata of shale.

In thin section pronounced changes are evident. The flinty and finer-grained hornfels is too dense to permit identification of its constituents, although a mixture of crystalline components is apparent. The Morrison hornfels is uniformly of this type, although locally it contains numerous small black spots 1 to 2 millimeters in size that consist of colorless chlorite and a small amount of pyrite. The Hermosa (?) formation contains numerous strata of the fine-grained flinty hornfels, and on Bear Mountain it locally grades into coarsegrained rock composed almost entirely of pyroxene of the diopsidehedenbergite series. The change, which is gradational, microscopically as well as megascopically, is not accompanied by any variation in color.

\section{QUARTZITE}

The quartzites generally appear less altered than the other sedimentary rocks. In thin section relatively pure quartzite, such as the Dakota (?), shows the tightly knit quartz-grain contacts typical of true quartzite. The less pure quartzites, those of Cambrian (Sawatch), Ordovician (Harding), Jurassic (Entrada in particular), and Pennsylvanian (Hermosa?) age, are darker than the Dakota (?) quartzite and in thin section show secondary minerals interstitial to the quartz grains. The minerals coarse enough to be identified are augite, tremolite, epidote, sericite, and possibly biotite. Some calcite is generally present, but whether as an introduced product or as the original cementing material could not be determined.

Several thin beds in the Hermosa (?) formation have been altered to massive rock consisting almost wholly of augite. They resemble quartzite but obviously could represent either a limy sandstone or a 
sandy limestone. The contact between the granite and quartzites was clearly defined in every exposure examined. Bain ${ }^{49}$ however, reports that many quartzite beds adjacent to the contact have been changed to feldspathic rock that is indistinguishable texturally or mineralogically' from granite. Locally, as at the head of Yule Creek, garnet (andradite) with some pyroxene (hedenbergite) has entirely replaced as much as 15 feet of the massive beds of the basal Jurassic quartzite for more than 100 feet along the strike. The replaced quartzite occurs along the Mississippian (Leadville) limestone, which is itself also replaced by the garnet.

\section{DOLOMITE}

Dolomite was invariably recrystallized, and metamorphism developed serpentine or diopside and secondary calcite at the expense of dolomite. The metamorphosed dolomite is usually some shade of gray and is fine-grained with either serpentine or diopside sufficiently abundant to be readily recognized. In contrast, the marbleized limestones are coarse-grained and white and, except locally, are free from any metamorphic silicates. A little tremolite was observed, but nowhere is it quantitatively important, and garnet was found in only a very few places.

Serpentine is not confined to any one horizon, but is much more conspicuous and abundant in the Manitou (Ordovician) dolomite than in any other bed. It is gray, green, or yellow and occurs in irregular bands or stringers parallel to the bedding or disseminated evenly through the rock. Small but distinct veinlets both parallel to and cutting across the bedding are not uncommon. The banded serpentine shown in plate $11, A$, is characteristic of the Manitou dolomite and is a means of recognizing this formation. At the head of Yule Creek individual bands of serpentine are fully half an inch thick and form an attractive rock that might be suitable as a building stone. Banded serpentinized dolomite of the Manitou is also well developed and is exposed on the north flank of Treasure Mountain on the slopes east and south of Whitehouse Mountain, but the outcrops are covered and do not extend down to the road along Crystal Canyon, where it is, however, represented by much float. Serpentine disseminated through dolomite is local in its development and can be recognized by the characteristic pitted surface produced by differential weathering. Fractured surfaces show the gray spots of serpentine in a groundmass of white calcite marble. The properties of the serpentine closely approach those of antigorite, although the fibrous habit of the mineral prevented the determination of all the diagnostic optical properties, and in places very small veinlets of serpentine were observed

49 Bain, G. W., Roof of the Treasury Mountain granite (abstract) : Geol. Soc. America Preliminary list of titles and abstracts of papers to be offered at the forty-ninth annual meeting, Cincinnati, Ohio, p. 7, 1936. 
that approached chrysotile both in index of refraction and in birefringence. In thin sections some of the disseminated serpentine showed slightly higher birefringence than the average for antigorite but otherwise appeared similar.

Diopside is as widespread and almost as abundant as serpentine. It is gray to white and as a result is not always conspicuous. Like serpentine, diopside has developed in all the dolomites, and, although the two minerals are found in the same specimen, diopside is most characteristic in those strata in which serpentine is less common, Diopside occurs in very irregular bands parallel to the bedding and is also widespread as a disseminated mineral. On weathered surfaces the irregular bands of diopside show a peculiar ribbed pattern. (See pl. 11, B.) The resistant "ribs" are dolomite, and the depressions mark areas of calcite and diopside. On freshly fractured faces the diopside is either inconspicuous or not evident and cannot as a rule be recognized megascopically. In thin section the coarser-grained diopside is readily recognized because of its high relief and its birefringence. The finer-grained diopside commonly occurs along the grain boundaries of the carbonate, where it is not easily recognized; several specimens examined in thin section appeared to contain only carbonate, and yet by dissolving the specimens in hydrochloric acid an appreciable percentage of diopside was found. The diopside has the common habit of forming essentially equidimensional grains in which cleavage is only poorly developed. It is replaced by serpentine where the two are associated, and very commonly it is also partly replaced by calcite. Lathlike crystals with characteristic pyroxene twinning and cleavage occur locally. The indices of refraction indicate a relatively pure diopside.

Calcite formed with both serpentine and diopside at the expense of the mineral dolomite, and locally veins of white calcite cut the recrystallized dolomite. Extensive replacement of dolomite by calcite may have occurred in the beds immediately below the Mississippian (Leadville) marble. Gillson ${ }^{50}$ reports marked replacement of dolomite by calcite in contact metamorphism in the Pioche district, and this phenomenon may be more common than has been realized. It is possible that this may have a significant bearing on the characteristic sulphide mineralization in dolomite zones relatively distant from areas of contact metamorphism.

\section{LIMESTONE}

The Mississippian (Leadville) limestone is the outstanding formation in the area, and it has been recrystallized to an attractive white rock known commercially as the "Yule Colorado marble." The Fre-

\footnotetext{
${ }^{80}$ Gillson, J. L., in Westgate, L. G., and Knopf, Adolph, Geology and ore deposits of the Pioche district, Nev.: Geol. Survey Prof. Paper 171, p. 37, 1932.
} 
mont limestone, the highest formation of the Ordovician, is also a white marble very similar in appearance to the Yule Colorado marble. In both formations metamorphic minerals are lacking over large areas; in fact, except for masses of garnet related to the upper contact, it can be said that silicates are essentially lacking in the pure calcite marble. The marble in direct contact with granite has become extremely coarse-grained.

Irregular masses of a grayish rock composed of fine-grained cloudy dolomite are encountered in the quarries of the Yule Colorado marble. They are termed "lime" by quarrymen and constitute an objectionable feature because of their color and the fractures they invariably contain. Two types of "lime" are present. (See pl. 12, $A, B$.) One type (pl. 12,A) has gradational and uneven boundaries, and masses of it range from a few inches to several feet across, with a definite tendency to elongation parallel to the bedding. The fractures are partly or wholly filled with calcite, which also replaces the walls, forming white bands across the dolomite. This replacement is evident only on large cut faces and not in thin sections. The cloudiness and the fine grain of the dolomite (0.05 to 0.10 millimeter) suggest that it is a primary texture, as the recrystallized dolomite consists only of aggregates of the clear colorless mineral. It is concluded that the rock was originally dolomitic and therefore slower to recrystallize completely.

The second type of "lime" differs in most respects, except color, from the first. It has a tabular form (pl. 12, B), with welldefined boundaries parallel to the bedding. Cross sections are lenticular, in places 4 feet long and about 1 foot thick. The larger masses show an interior consisting of calcite surrounded by an indistinct rim about an inch wide of a dense rock composed of granular quartz, calcite, and small amounts of tremolite. The boundary of each side of the rim is gradational, and the quartz occurs throughout its width, but the tremolite is confined to the outside border. The quartz grains, only a fraction of a millimeter across, show inclusions tentatively identified by their high index of refraction and birefringence as diopside.

The origin of this second type of "lime" is not clear, but local concentrations of sphalerite along the border suggest that mineralizing solutions formed them. These occurrences of sphalerite are not common; quarrymen reported only occasional occurrences of this kind during several years of quarrying. However, sphalerite in veins throughout the area is accompanied by silicification, and the presence of even a small amount of the sulphide suggests a similar relation. 
Locally the Yule Colorado marble is veined by coarse gray calcite. The veins are irregular and are finer-grained at the margin than at the center. Also the gray calcite forms nodular masses 2 to 3 feet across and the matrix of white marble breccia. These several features are shown in plate $13, A$. The coarse gray calcite was observed in the quarry near the upper part of the bed of marble. It occurs only locally, and its significance is not clear.

\section{SANDY SHALE AND SHALY LIMESTONE}

The Hermosa (?) and Maroon formations vary much in lithology and composition. Details of the original character of a particular metamorphosed stratum on Treasure Mountain can therefore only be inferred, but in spite of the changes it is evident that before metamorphism the Hermosa (?) formation in neighboring areas consisted of sandstone, shales, limestone, dolomites, and rocks of intermediate composition. There can be little question that the Maroon beds that are now gray were formerly red, as they are in neighboring areas. It has not been possible, however, to determine whether a metamorphosed sedimentary rock with one or more of the secondary silicates represents sandy shale, shaly limestone, or a rock of some intermediate composition. For this reason, and because they show a greater variation in metamorphic silicates than is found in the rocks of simpler composition, these formations are considered separately.

The Hermosa (?) formation contains numerous calcareous beds, many of which have an appreciable content of magnesium and have developed an abundance of diopside and serpentine as well as local small amounts of tremolite. These minerals are particularly conspicuous along cherty zones in calcareous rocks. In places in Bear Basin chert nodules in all stages of replacement by serpentine (antigorite) were found, and some of these nodules contain coarse antigorite crystals resembling mica in general appearance. Garnet and epidote are particularly characteristic of these intermediate sedimentary rocks. Individual beds of relatively pure dolomite, shale, and quartzite show the usual diopside and serpentine already described as occurring in rocks of these compositions. The general effect of metamorphism has been to accentuate the bedding by producing a particular combination of silicates that expresses the original composition of each bed. The result is that in outcrop the Hermosa (?) formation is distinctly banded; this banding and the limestone content set it apart as distinct from any other formation.

The Maroon formation contains an abundance of epidote and also some garnet. Epidote occurs through the entire formation in small amounts. It is found in the interstices between the grains and coating surfaces of joints and probably accounts for the loss of the 
original red color of the formation. 'Garnet (andradite) is scattered throughout the formation and is commonly concentrated in limestone pebbles of the conglomerate, but garnet does not replace individual beds.

Locally the feldspathic sandstones, especially the fine-grained ones, resemble altered igneous rocks of intermediate composition even in thin section. The general effect of the changes has been to make the bedding stand out just as it does in the Hermosa (?) formation. However, the feldspathic content and the presence of conglomerates make the recognition of the Maroon formation easy.

\section{INFLUENCE OF STRUCTURE ON METAMORPHISM.}

Proximity to the granite has had less influence on the character and degree of metamorphism than faults and sedimentary contacts. In places rock several thousand feet from the granite has been more completely replaced or recrystallized than rock in contact with granite.

Metamorphic minerals are concentrated in several places along contacts of sedimentary formations and locally along the contact between the granite and calcareous sedimentary rocks. These zones of metamorphism consist of beds of garnet 50 feet thick and of diopside with magnetite 10 feet thick. They therefore stand out in contrast to rocks showing the general changes previously described. Much massive yellow-brown to green garnet (andradite) has developed along and in the upper part of the Mississippian (Leadville) marble at the head of Yule Creek, and certain beds in the Maroon formation on the west slope of Treasury Mountain are also highly altered. The alteration of these beds may, however, be more closely related to small faults than to favorable contacts. The massive garnet averages only a few feet in thickness but may be as much as 50 feet thick, and in addition there are numerous irregularshaped bodies of garnet in the upper part of the marble. The contact of garnet and marble is everywhere sharp, and nowhere does the marble contain veins or disseminated silicates. With the garnet there are small amounts of hedenbergite and epidote. The epidote coats the surfaces of vugs and is therefore a late mineral. The rel. ative age of the hedenbergite is not certain, but it is intergrown with the garnet, and the two appear to be essentially contemporaneous. In the same area similar masses of garnet are found along some of the calcareous beds of the Hermosa (?) formation. The amount or intensity of replacement does not appear to be related directly to their proximity to the intrusion; in fact, the intrusive contact as a whole exhibits relatively little metamorphic action. It seems, therefore, that the concentration of the massive bodies of garnet or diopside with magnetite was largely dependent on or controlled by 
certain favorable structural conditions and by permeability in the same degree that these features commonly control the formation of metalliferous deposits.

The slight metamorphism along the intrusive contact is dependent in part on the nature of the wall rock. For example, where the wall rock is gneiss or quartzite no indication of alteration was noted. Where the granite is in contact with the marbleized Leadville (Mississippian) limestone silicates have not formed, but the grain of the marble is invariably coarse, averaging 1.0 to 2.0 centimeters, whereas elsewhere it uniformly averages about 2 millimeters. Intrusive contacts between granite and dolomite, limestone, and mixed sedimentary rock show slight to marked changes. On Bear Mountain much biotite was found through a narrow zone in the Pennsylvanian sandstones, whereas along the north side of Crystal Canyon no unusual changes were noted. On the east side of Bear Basin, where the granite cuts across the Devonian dolomite, massive green diopside with some magnetite 3 to 10 feet thick is present.

The influence of faults on metamorphism is shown on Treasury and Galena Mountains and at the head of Rock Creek. In these areas manganiferous hedenbergite is characteristic and locally abundant in the veins along the faults, and the walls of the veins contain much diopside, garnet, and some tourmaline. The Mancos shales are noticeably more indurated along the fault zone on the northwest slope of Sheep Mountain and to the southwest on Rock Creek and on the west side of Emerald Lake. Garnet (andradite) is very common in the Maroon beds along this fault zone, whereas it is almost lacking at the west end of Sheep Mountain, outside of the fault zone. Just how much of the metamorphism can be attributed to the faulting cannot be determined, but the presence of hedenbergite and tourmaline in the veins along some of the faults indicates that solutions passed along them. The general effect of the faulting seems to have been to cause relatively strong alteration in places more remote from the intrusion than would have been affected had no faults. been present.

The veins with manganiferous hedenbergite represent a transition between rock alteration due to metamorphic processes and the formation of veins containing sulphides. This relation is described in the section on sulphide mineralization.

\section{ORIGIN OF METAMORPHIC SILICATES}

Some of the metamorphic changes necessitate the introduction of metamorphic materials, and others are most logically explained by simple recrystallization. Thus limestone changed to marble and shale to hornfels by simple recrystallization, whereas the massive 
beds of garnet along the sedimentary contacts and along faults could form only by the introduction of materials.

The origin of the silicates in the dolomites is more obscure, but the marked control of the composition of the rocks in general is significant. All the silicates in dolomite, shale, and intermediate rock can be theoretically accounted for by an increased activity of the connate water due to a rise in temperature, which would necessarily accompany the intrusion of the granite. It is difficult to evaluate the importance of material, if any, introduced by solutions, but if all the elements represented by the metamorphic silicates circulated freely the minerals should not be much more characteristic of one horizon than of another, and they could be expected to occur, in small amounts at least, in the limestones as well as in the dolomites. The diopside with calcite which developed the ribbed pattern in the Dyer (Devonian) dolomite, shown in plate $11, B$, could reacily have formed by recrystallization of a siliceous dolomite, shown in plate 11, $C$, and does not suggest introduction of much material. Dolomite of the Devonian is known to contain free silica, and yet free silica was not observed with the diopside and calcite in the metamorphosed dolomite of this age on Treasure Mountain, a fact which suggests that it was utilized to form the silicates.

Where solutions circulated freely, as along the faults, silica was introduced, and as the metamorphosed dolomite, limestone, and shale do not as a whole contain free silica the conclusion is that the solutions did not circulate freely through these rocks. Therefore little or no material was introduced, and the metamorphic minerals formed at the expense of those originally present in the rock. Along faults and contacts that were sufficiently pervious the solutions introduced elements, either with or without an exchange of material, to form massive bodies of andradite, diopside, and hedenbergite.

\section{STRUCTURE}

\section{GENERAL FEATURES}

The outstanding structural features of the area are the preJurassic angular unconformity, the Elk Mountain fault, and the dome of Treasure Mountain. The faults along which mineralization occurred are a part of the dome structure and are therefore included with it. These features, except the faults related to the Treasure Mountain dome, have no bearing on the mineralization of the area, but they are of general interest in their relation to the geologic history not only of the Elk Mountains but also of the Sawatch Range and the White River Plateau.

As only one of the three structural features is important in relation to ore deposits, they are described in the order of their relative 


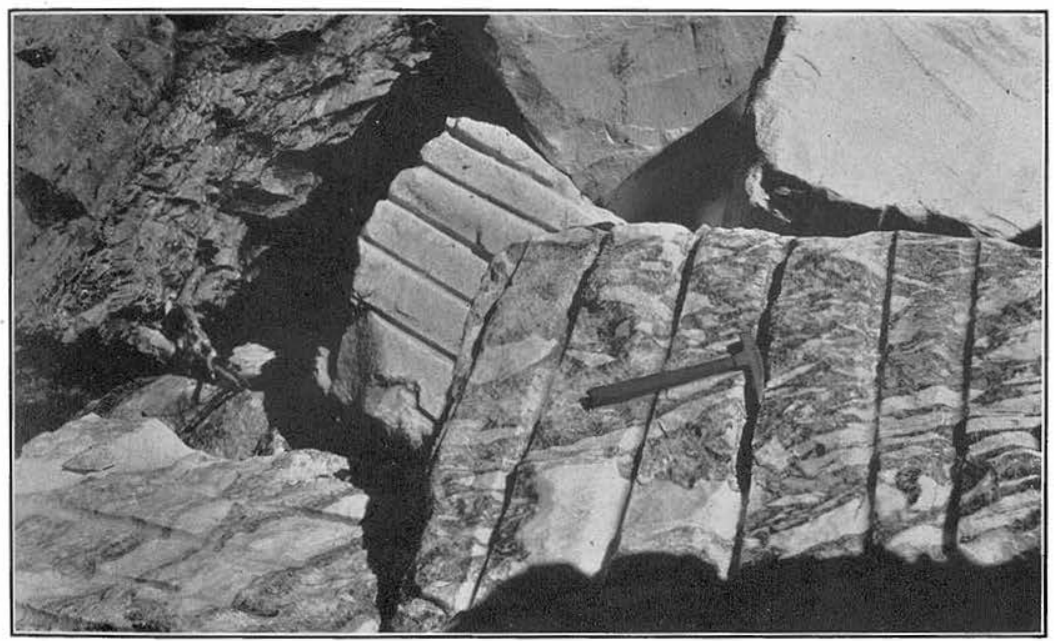

\section{A. COARSE GRAY CALCITE OCCURRING IN VEINS AND AS MATRIX OF WHITE} MARBLE.

Found locally in upper part of the Mississippian (Leadville) limestone in the Yule Colorado marble quarry.

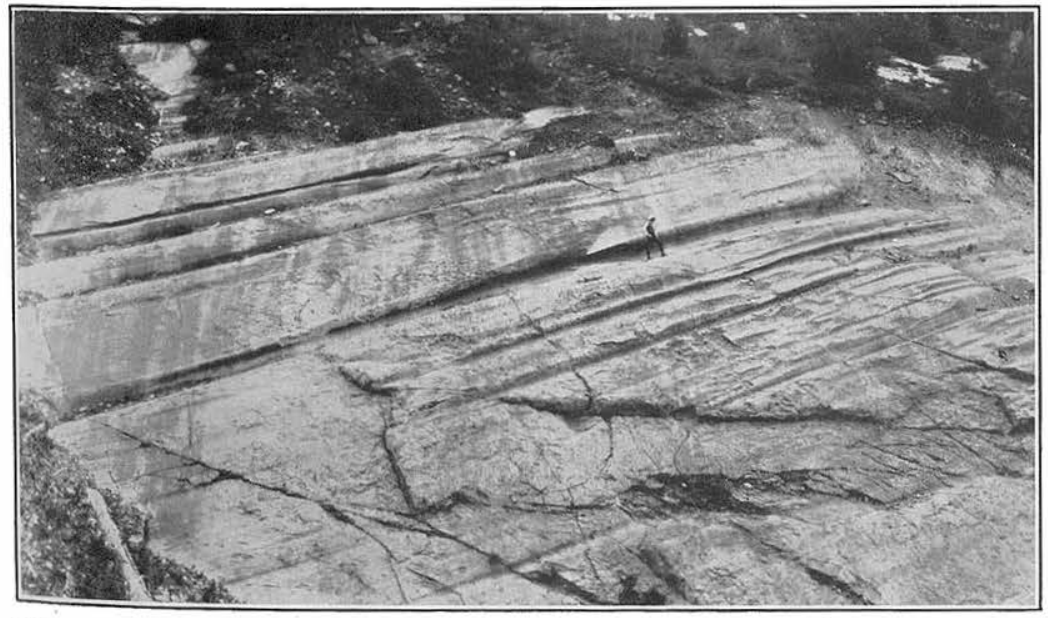

B. GLACIAL GROOVES IN DEVONIAN DOLOMITE IN YULE CREEK A LITTLE EAST OF THE YULE COLORADO QUARRY. 


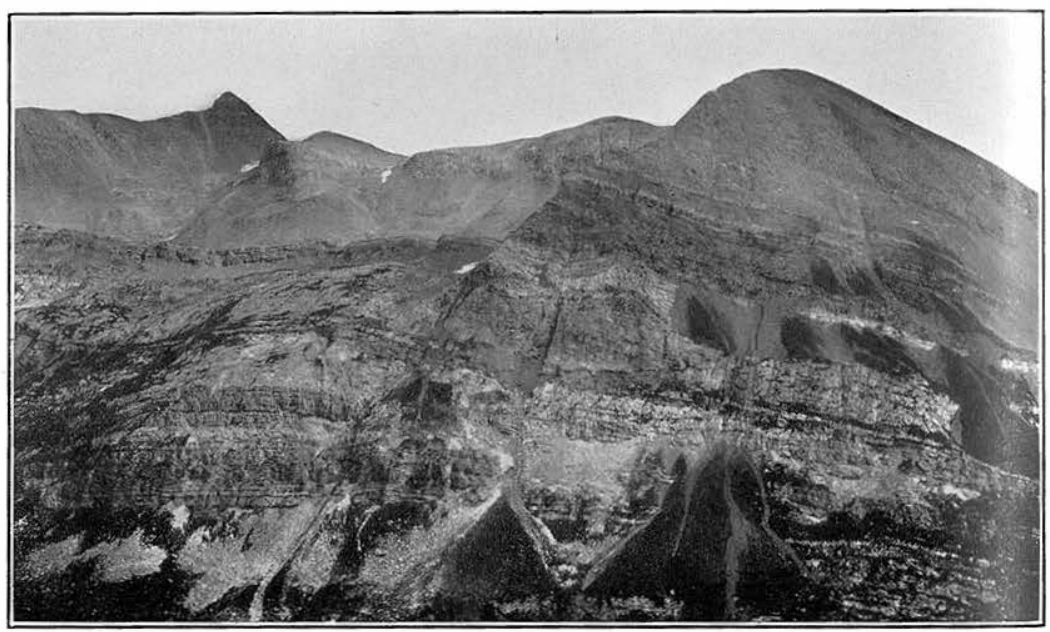

A. ANGULAR UNCONFORMITY BETWEEN THE PALEOZOIC AND JURASSIC FORMATIONS AS EXPOSED NEAR THE HEAD OF YULE CREEK ON THE SOUTH SIDE OF THE VALLEY.

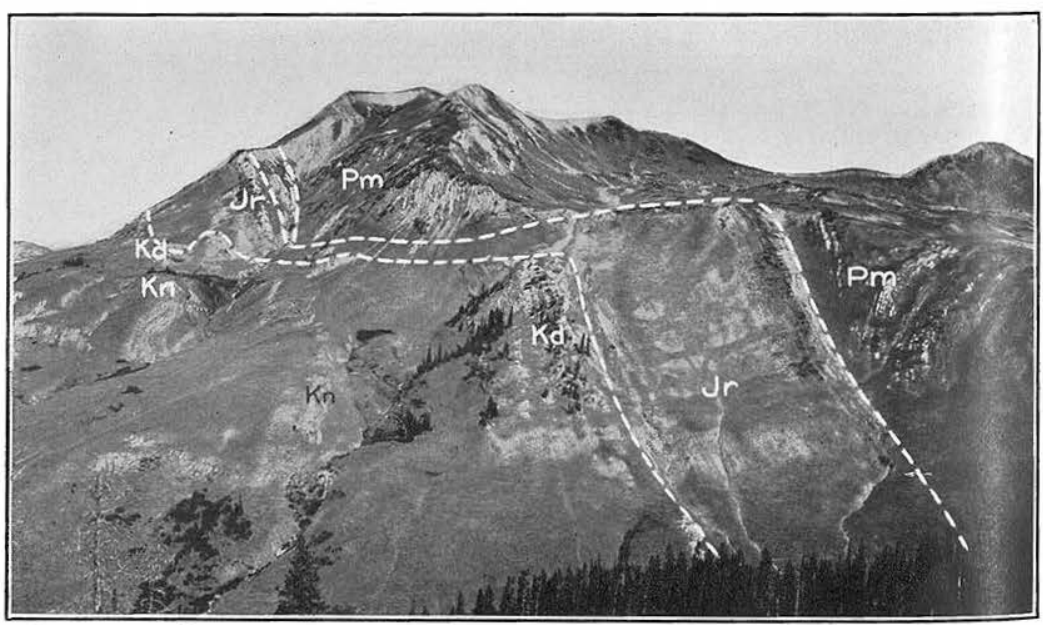

B. ELK MOUNTAIN FAULT ZONE EXPOSED ON NORTHWEST SIDE OF THE EAST FORK OF ROCK CREEK EAST OF SCHOFIELD PARK.

$\mathrm{Kn}$, Limestone of Niobrara age in the Mancos shale; Kd, Dakota (P) quartzite; Jr, Jurassic rocks; Pm, Maroon formation. 
geologic age. The pre-Cambrian structure is unknown. Within the area no evidence has been found of folding or faulting throughout Paleozoic time, as the Paleozoic beds show only disconformable contacts. Bain ${ }^{51}$ has suggested that the marked linear structure of grains in the marbleized Leadville limestone and the presence of pebbles of identical rock oriented at random in overlying conglomerate beds of the Hermosa formation may imply a distinct deformation and therefore marbleization of the Leadville limestone in pre-Hermosa time, but, as no evidence of distinct folding at that time has been found anywhere in Colorado, it is difficult to prove sufficient deformation for the formation of marble. It must also be admitted that the Leadville limestone is dark blue throughout the State, except where affected by igneous intrusion or mineralizing solutions, and therefore that its white color in the Snowmass area is consistently attributed to the influence of the intrusive granite and associated mineralizing solutions.

The earliest period of folding is indicated by the angular unconformity at the base of the Jurassic. After this folding, quiet again prevailed through the period of erosion represented by the flat surface of the unconformity and continued through the deposition of the Cretaceous beds. Movements involving displacements of more than 7,000 feet along the Elk Mountain fault zone came at the end of the Cretaceous period and in early Tertiary time and produced the regional southwest dips west of the fault zone and the regional northeast dips east of it. The duration of these movements is not known, but after they ceased the granodiorite in the Elk Mountains and the granite of Treasure Mountain came into place. The intrusion of granite arched the overlying sedimentary beds and produced some faults and fractures, along which mineralization occurred as the closing chapter of a history of volcanic activity.

\section{PRE-JURASSIC ANGULAR UNCONFORMITY}

The presence of the angular unconformity at the base of the Jurassic is shown on the geologic map of the Crested Butte quadrangle (Folio 9). As the Jurassic (Gunnison formation of the map cited) cuts out the Paleozoic formations in an area of poor exposures where there is evidence of thrust faults, the true nature of the relations has been in some doubt. On Treasure Mountain the angular surface of the Paleozoic is well exposed in several places but probably better shown at the head of Yule Creek (pl. 14, $A$ ) than elsewhere. This. surface ranges in dip from $20^{\circ}$ to $28^{\circ}$. The lower figure was obtained by direct measurement in North Pole Basin, and the higher figure: was calculated from the fact that formations 4,800 feet in total thick-

${ }^{51}$ Bain, G. W., oral communication. 
ness are cut out from Lead King Basin to Yule Creek in a distance of 26,000 feet.

The present form of the surface of the unconformity is that of a dome conforming with the general shape of the Treasure Mountain uplift. The line of contact, however, is an even line wherever the surface is exposed, whether along or across the strike of the beds. Hunter ${ }^{52}$ describes the base of the Jurassic along the Gunnison River as "remarkably sharp and straight" and regular except where disturbed by later faulting. Burbank ${ }^{53}$ has noted a similar relation in the San Juan Mountains. From this evidence it is concluded that the surface on which the Jurassic was deposited was a well-developed peneplain.

An effort was made to determine the trend of the beveled edges of the Paleozoic beds across the pre-Jurassic surface. Direct observations are not easily interpreted because of the doming of Treasure Mountain. Along Yule Creek the trend of the beveled edges is about N. $50^{\circ}$ W. A line drawn from this area to that of the Crested Butte quadrangle along the southwestern limits of the Paleozoic beds trends N. $40^{\circ} \mathrm{W}$. These two figures are in fair agreement and mark the probable trend of the sedimentary formations that cropped out on the flat pre-Jurassic surface. This structure is parallel to that of the dominant trend of the more recent Rocky Mountains and is in accord with the general belief that the crustal disturbances of the later periods were probably controlled by the structure established much earlier.

\section{STRUCTURE OF TERTIARY ROCKS}

The Tertiary structural disturbances in the area are discussed in the order of their sequence, which is intrusion of dikes and sills along a northeastward-trending zone, regional diastrophism that made the Elk Mountain fault zone, and igneous intrusion that made the Treasure Mountain dome.

The dikes and sills are related to intrusions known to be younger than the Tertiary formations in the Anthracite quadrangle, ${ }^{54}$ to the south, and the Elk Mountain fault zone involves the Tertiary beds in the Huntsman Hills and Grand Hogback, to the northwest.

\section{NORTHEAST TREND OF EARLY DIKES}

In the southeastern part of the area are several dikes of the Lincoln porphyry type with a northeast trend. This trend is parallel to and in line with that of many of the dikes of the Ruby Range, in the Anthracite quadrangle, to the southwest, but it has no recognized

\footnotetext{
Hunter, J. F., Pre-Cambrian rocks of Gunnison River, Colo.: Geol. Survey Bull. 777 , pp. $7-8,1925$.

s Burbank, W. S., personal communication.

4 Eldridge, G. H., op. cit. (Folio 9).
} 
local significance or importance. It is of interest because of its parallelism to the mineral belt from the San Juan Mountains to Boulder County. The structure is older than the Elk Mountain fault zone, as the dikes are displaced along that zone. The dikes are also faulted as well as altered by the intrusion of the granite of Treasure Mountain. This northeasterly trend is therefore the oldest recognized Tertiary structure in the area.

\section{ELK MOUNTAIN FAULT ZONE}

Principal features.-The Elk Mountains contain three large in. trusions of granodiorite along a zone of uplift, folding, and faulting. This zone will be referred to in this report as the Elk Mountain fault zone. (See pl. 1.) Hayden ${ }^{5 s}$ discovered the zone in 1873 and described the overturned beds between Mount Belleview and Snowmass Mountain. His interest led him to have a special study made of the Elk Mountains in 1874 by Holmes, ${ }^{56}$ who in his report described the structure in some detail as a "fault-fold." Holmes' analysis and interpretation are embodied in his illustrations reproduced on plate 15. Neither Hayden nor Holmes discussed the continuation of the fault-fold beyond the limits of the Elk Mountains proper. Hills ${ }^{57}$ has pointed out that to the north and northwest the fault zone is continuous with the Grand Hogback fold, which in turn continues to the northwest and thence west along the south side of the Uinta Mountains to the Wasatch Mountains in Utah. In view of the fact that the structure was known to continue for many miles to the north it is surprising that Eldridge ${ }^{88}$ in his description of the Crested Butte quadrangle did not consider more seriously its extension southward. $\mathrm{He}$ remarked in passing that certain overturned beds and sharp anticlinal folds resemble and are parallel in trend to the fault-fold of the Elk Mountains, but he made no effort to correlate the two, although the relation seems to be apparent. It remained for Burbank ${ }^{58}$ to trace the fault zone from the Crested Butte quadrangle to a point a short distance south of the Gunnison River.

It is not feasible in a report of this kind to discuss in detail regional structure that extends for many miles beyond the limits of the area described. However, it is necessary to consider some of the regional aspects of the fault zone in order to bring out its relation to the large intrusions of granodiorite. In addition, there are certain

\footnotetext{
BHayden, F. V., Geology of Elk Mountains: U. S. Geol. and Geog. Survey Terr. 7th Ann. Rept., pp. 58-69, 1874.

"Holmes, W. H., Report on the geology of the northwestern portion of the Elk Range :

U. \$. Geol. and Geog. Survey Terr. 8th Ann. Rept.; pp. 57-72, 1876.

" Hills, R. C., Orographic and structural features of Rocky Mountain geology : Colorado

Sel. Soc. Proc., vol. 3, p. 409, 1891.

Eldridge, G. H., op. cit. (Folio 9).

Burbank, W. S., Geologic map of Colorado, 1936.
} 
aspects that promise to throw light on Rocky Mountain structure and geologic history. Field work, particularly in the area to the south of the Elk Mountains, was insufficient to permit a detailed consideration of the regional nature of the fault zone, but as many facts as were observed and are known will be added to the more local description.

Local features.-On the slopes east of Schofield Park Maroon red beds occur above 800 to 1,000 feet of younger overturned strata. These younger strata include Entrada and Morrison formations (Jurassic), Dakota (?) quartzite (Cretaceous), and the lower 200 to 300 feet of the Mancos shales (Cretaceous), including the limestone of Niobrara age and the shale of Benton age. The strike of the overturned beds and the Maroon beds is parallel, and they all dip eastward. As seen from a distance, these strata lie in apparent conformable relations for a distance of more than 6 miles in the area between Snowmass Mountain on the north and Mount Belleview on the south. Throughout this distance (see pl. 6, $A$ ) the continuity of the exposures of the Entrada and Morrison formations, Dakota (?) quartzite, and limestone of Niobrara age in the Mancos shale does. not give an impression of the great disturbance involved. Even a detailed examination of outcrops in most places shows only apparent conformable and normal depositional relations. True relations are shown, however, where the fault zone is traversed by an east tributary of Rock Creek. On the south side of this tributary near the saddle north of Mount Belleview (see pl. 1) the continuity of the Morrison shale and Dakota (?) quartzite is interrupted, and the faulted ends of these formations have been squeezed into a sharp isoclinal anticline that plunges very sharply to the south. On the north or opposite side of this valley the crumpled Maroon red beds are exposed (see pl. 14, $B$ ) as they appear east of the main zone of overturned Jurassic and Cretaceous beds. The close folding evident in plate $14, B$, is as a rule not apparent on the beveled edges of the beds, which everywhere are essentially parallel. In most places, however, the Maroon strata dip $70^{\circ}-85^{\circ} \mathrm{E}$., whereas the overturned younger beds dip $55^{\circ}-60^{\circ} \mathrm{E}$. The cross section shown on plate $14, B$, is therefore not a mere local feature.

The Maroon beds south of Snowmass Mountain that dip $75^{\circ}-85^{\circ}$ E. occupy a zone 3,000 to 4,000 feet wide. Adjacent to this zone on the east the Maroon beds have dips of only $20^{\circ}-30^{\circ}$, which flatten to $5^{\circ}$ or $10^{\circ}$ on the west flank of Maroon Peak. Gentle easterly dips continue to the east and north without apparent interruption as far as the Aspen district, 10 to 15 miles distant. The boundary between the steeply dipping beds and the gently dipping beds marks a thrust-fault surface that was followed by the long tongue of granodiorite. In the southern part of the area the thrust 
fault cuts out the steeply dipping Maroon beds, and in Rustler Gulch, just south of the area, it cuts out all the overturned formations as well as all the Mancos shale. At the head of Rustler Gulch faulted Maroon strata rest on Dakota (?) quartzite, and the thrust fault is intersected at a relatively steep angle by the granodiorite of White Rock Mountain. The Elk Mountain fault zone, including the overturned Jurassic and Cretaceous beds and the steeply dipping Permian beds in the northern part of the area, is over a mile wide; and to the south, in Rustler Gulch, where the overturned strata are cut out, the width of the fault zone is less than 200 feet.

Movement.-Three types of movement are represented in the Elk Mountain fault zone-first, vertical and horizontal displacements that resulted from the formation of a monoclinal fold; second, apparent reverse or upthrust faulting in which the horizontal and vertical components of movement were nearly equal; and third, thrust faulting in which the horizontal movement predominated. It is not possible to estimate the amount of displacement referable to each type of movement. In fact, the total combined displacement that has occurred along the Elk Mountain fault zone cannot be determined accurately because key beds are lacking. The series of beds (Maroon formation) with gentle easterly dips referred to above is more than 4,000 feet in total thickness near Maroon Peak, and beyond toward Aspen an additional thickness of several thousand feet appears to be present in an unbroken succession. Although a repetition of beds was not recognized it is not safe to infer without further study that repetition of beds could not have occurred. The Maroon beds west of the thrust fault are folded, and they stand nearly on end in a zone about 4,000 feet wide. In this zone repetition is suggested, as is shown on plate $14, B$, but whether these beds represent the upper, middle, or lower part of the Maroon formation could not be determined. The lowest of the Maroon beds east of the thrust fault dip gently eastward and are 2,000 feet vertically above the Dakota (?) quartzite in Schofield Park. Holmes in 1874 estimated the vertical displacement at 8,000 to 11,000 feet, and Hills in 1890 estimated it at 8,000 feet. The great thickness of Maroon beds to the east implies a large displacement-in fact, if there is no repetition of beds there must be a relative uplift on the east of fully 12,000 feet.

The amount of horizontal movement of the upthrust is also difficult to ascertain. Holmes estimated it as not less than 6,000 feet, which is indeed a conservative figure, as the dip of the fault necessitates a horizontal component, normal to the strike of the fault, comparable to the vertical component. If, as seems probable, the isolated masses of Morrison shale and Dakota (?) quartzite along the thrust fault (see pl. 1) were dragged from the edges of the overturned beds north- 
east of Mount Belleview there may be a north component of the thrust amounting to 1 or 2 miles. There is no other apparent source for these isolated slices of Morrison and Dakota (?) beds unless they are the continuation of the overturned strata to the west, which would also call for a large horizontal component. Evidence of faulting in the Mancos shale could not be found. Moreover, there is good reason, as originally stated by Holmes, for believing that the overturned formations constitute the eastern limb of a sharp syncline lying to the west. (See cross sections, pl. 1.) The amount of move-: ment along the fault zone decreases and apparently dies out to the north, and it appears to increase to the south. This relation has been confused by the two large stocks of Snowmass and White Rock Mountains, both of which have been intruded along and across the faults and have thus complicated field relations. The Castle Creek fault at Aspen is very similar in many of its features to the Elk Mountain fault zone. Recent studies indicate that the fault near Aspen may be continuous with a zone of thrust faulting in the vicinity of Tincup and Pitkin, ${ }^{\circ 0}$ about 60 or 70 miles to the south. Similarly the thrust faulting of the Elk Mountain fault zone also continues for some distance to the south.

Northward extension.-The fault zone in the Elk Mountains is part of a regional structure that extends northward unbroken to the Uinta Mountains. I followed this structure for a distance of more than 100 miles, to a point 20 miles northwest of Price Creek, a post office in Moffat County. Throughout this distance this zone is unbroken except for the intrusion of Snowmass Mountain, which cuts it out for 3 or 4 miles. The outstanding features observed in going northward are marked changes in strike (see fig. 6) and the progressive change from the area of thrust faulting and upthrusts accompanied by overturning of beds east of Schofield Park to an area of normal faulting in the limb of a well-developed monocline at Placeta, about 12 miles northwest of Marble. Farther north the structure changes to that of a sharp monocline with relatively little faulting.

The marked changes in strike (see fig. 6) are (1) from N. $30^{\circ} \mathrm{W}$. in the area east of Schofield Park to nearly west in the area north of Marble; (2) from west to almost north near Placeta, continuing north for a distance of about 30 miles along the west side of the Crystal River and the Roaring Fork to Glenwood Springs; and (3) at Glenwood Springs to N. $70^{\circ} \mathrm{W}$. for nearly 25 miles, beyond which it again curves more nearly north for 25 miles to a place where it crosses the White River west of Meeker. This section from Glenwood Springs to the White River is the Grand Hogback proper,

${ }^{\infty}$ Butler, B. S., Burbank, W. S., and Goddard, E. N., personal communication. 
and for this distance the structure flanks the White River Plateau. North of the White River for 10 miles the strike changes to northeast, as if continuing around the plateau, but it abruptly veers back to $\mathrm{N} .40^{\circ} \mathrm{W}$. and maintains this course at least as far as a point 20 miles beyond Price Creek post office. The course beyond this point shown in figure 6 is taken from Hills' description, already
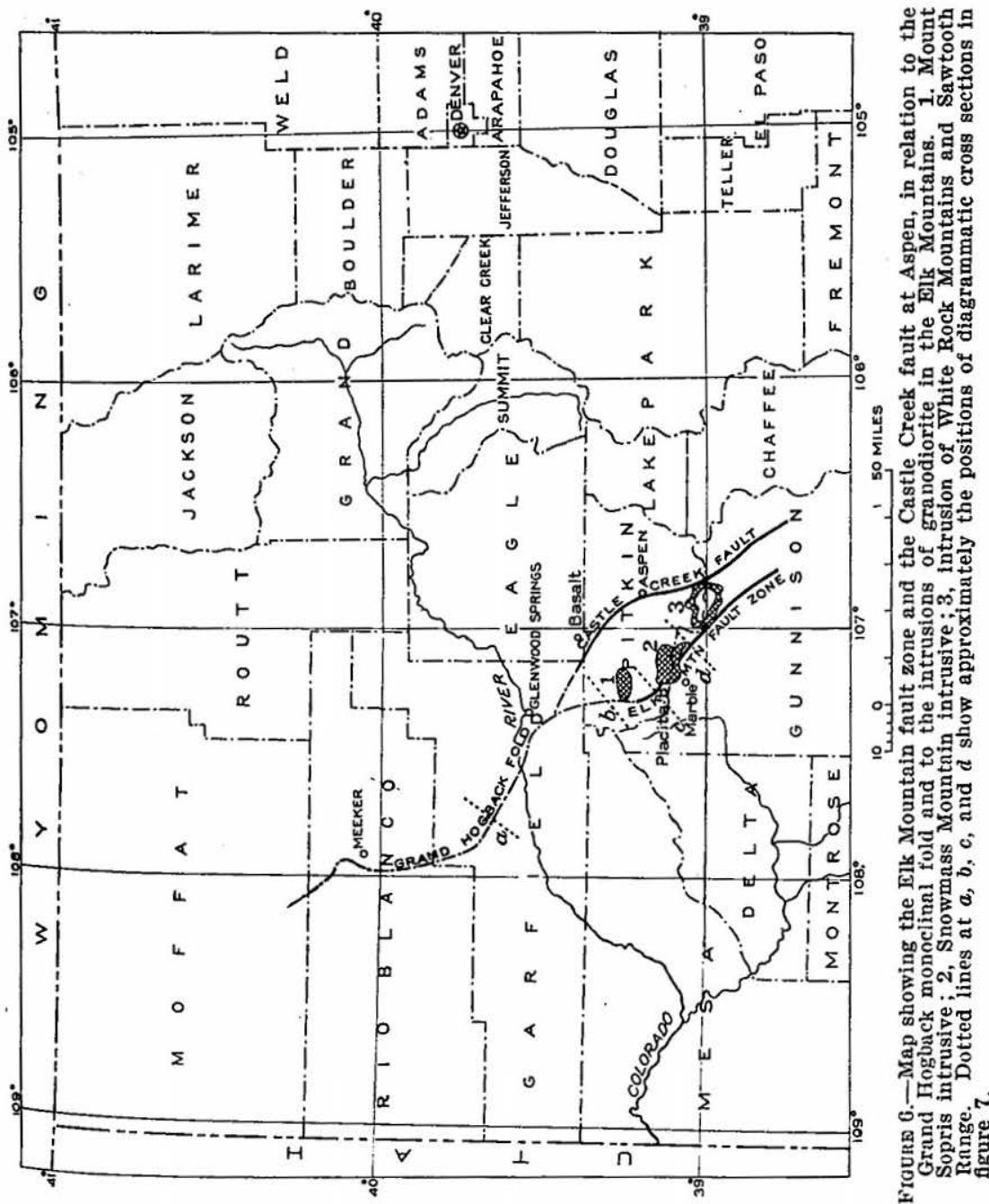

cited. The course to the south continues along a line of disturbance across the Crested Butte quadrangle, described by Eldridge, and farther south, as mapped by Burbank. Because of the several changes in trend, an attempt to extend mapping of the structure beyond the limits covered by field observation is unwarranted. 
The changes in the character of the faulting and folding from Schofield Park, where the fault zone is cut off by the stock of Snowmass Mountain, to the continuation of the structure on the west side of the stock near Placeta, on the Crystal River 12 miles northwest of Marble, are very striking. (See figs. 6 and 7, cross sections $c$ and $d$.) From this place northward the structure is that of a sharp monoclinal fold with steep westerly dip. At Placeta much of the Mancos shale has been faulted out along a normal fault that has thrown the coal of the Mesaverde formation relatively close to the Dakota (?) quartzite. North of Placeta faulting was not recognized on the surface, but displacements of 100 feet are not uncommon in the old coal mines at Newcastle, west of Glenwood Springs.

An interesting feature is the relation between dips of the fold and fault and the curvature of the fault-fold zone. The dips are vertical where the strike changes from northwest to north and $40^{\circ}$ to $60^{\circ}$ where the strike changes from north to northwest at Glenwood Springs. Examples of the vertical dips are excellently exposed a few miles northwest of Placeta in the canyons of Coal and Thompson Creeks, where fully 5,000 feet of Permian, Jurassic, and Cretaceous beds combined (see pl. 10, $B$, and cross section $b$, fig. 7) are standing on end. A few miles north of Newcastle, where Rifle Creek crosses the Grand Hogback, about 7,000 feet of combined Cretaceous and Tertiary strata with vertical dips are well exposed.

Hills ${ }^{61}$ believed that the monoclinal fold had everywhere been overturned as it is now seen in parts of the Elk Mountains. He assumed that along the Grand Hogback where overturned beds are not found the overturned part of the fold has been removed by erosion. Fortunately some of the upper part of the fold is preserved in the vicinity of Thompson Creek (see pl. 10, $B$ ), from which it is evident that overturning of the beds did not take place everywhere along the fold.

The upper part of the fold was found only on Thompson Creek, and the lower part was not found here or anywhere else.

The dip changes very abruptly from vertical to $40^{\circ}$ or $50^{\circ}$ in a sharp flexure without faulting, and the line of this flexure slopes eastward at about $20^{\circ}$. It could not be determined whether this feature is local or general. The westerly dips of $40^{\circ}$ to $60^{\circ}$, common along the Grand Hogback fold, could well represent the upper part of the fold. It has been generally assumed that only the lower part of the monocline is present, but this assumption is not justified.

or Hills, R. C., Orographic and structural features of Rocky Mountain geology: Colorado Sci. Soc. Proc., vol. 3 , p. 411, 1891. 


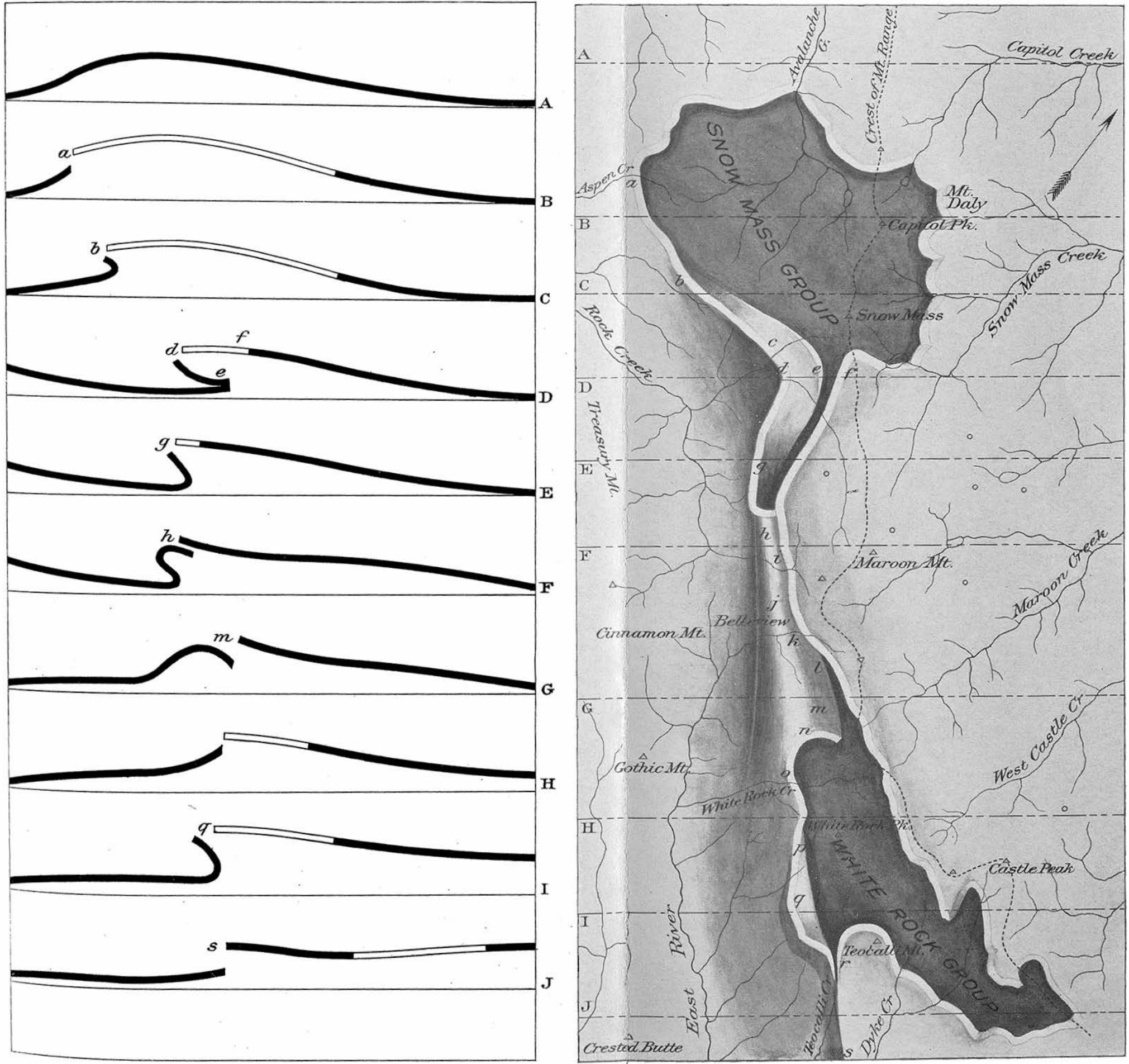

ELK MOUNTAIN FAULT ZONE ACCORDING TO HOLMES.

U. S. Geol. and Geog. Survey Terr. 8th Ann. Rept, for 1874, figs. 10, 11, 1876. 


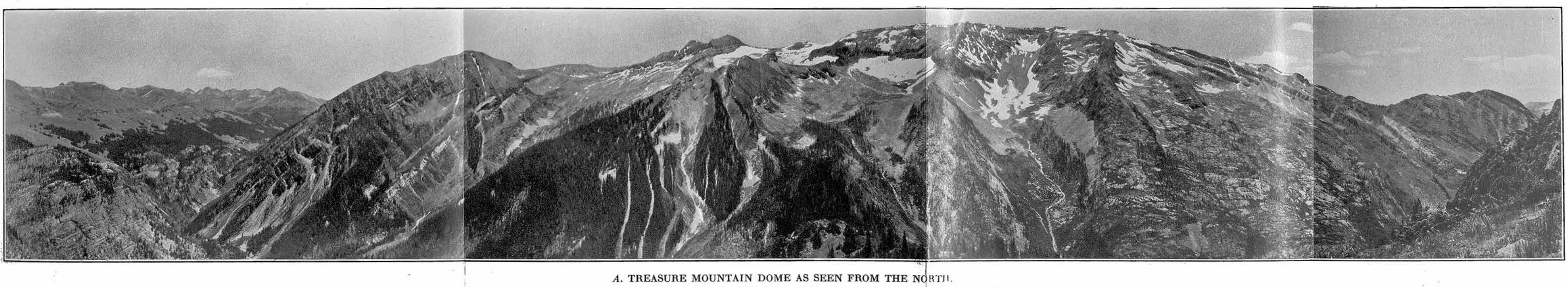

Treasure Mountain in center, with Treasury Mountain on left. Crystal Peak on extreme left and Whitehouse Mountain on right. The cli $\mathrm{F}_{\mathrm{s}}$ in the right foreground are a part of the south face of Sheep Mountain

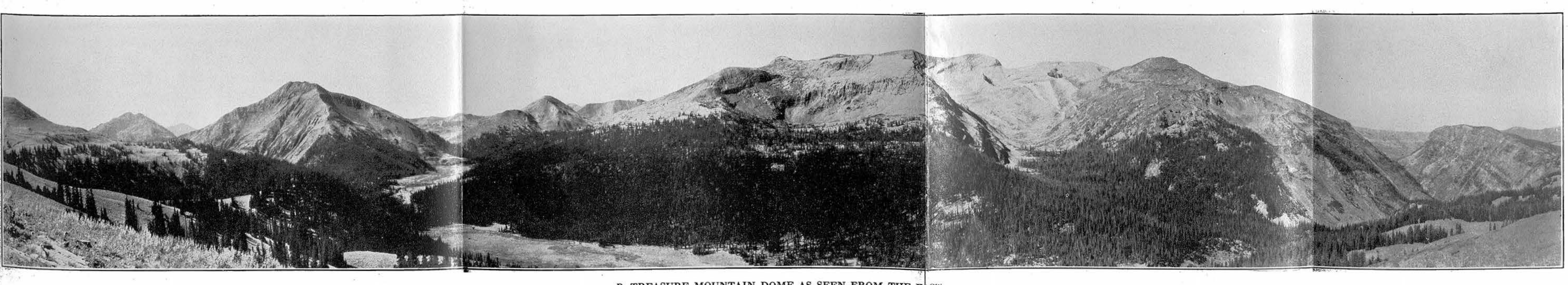


A discussion of the relation of this zone of regional folding and faulting to structural features, such as the White River Plateau on the east and certain anticlines on the west, is beyond the scope of this report. It is mentioned, however, in order to point out that the Castle Creek fault at Aspen is very similar in many respects, including size, to the Elk Mountain fault zone. ${ }^{62}$ The formations that are overturned in the Snowmass area are overturned in the same way along the Castle Creek fault near Aspen, and the fault changes to a monoclinal fold to the northwest. It continues northwestward from Aspen to Basalt along the valley of Roaring Fork. At Basalt the valley of Roaring Fork is northeast of the steeply dipping beds. A few miles below Basalt the valley veers to the southwest of the fold, which continues in a straight line and was traced to a point within 3 miles of the Grand Hogback fold, west of Glenwood Springs. There can be little doubt that the flexure, itself' a monoclinal fold northwest of Basalt, is related to the monocline of the Grand Hogback. It appears, therefore, that the northwestward continuations of the Elk Mountain fault zone and the Castle Creek fault join south of Glenwood Springs and that the two represent a branching flexure. The data now available indicate that the relative movement of each of the two branches was about the same.

The features of the Elk Mountain fault zone and the Grand Hogback fold suggest probable stages of development that preceded the close folding and thrust faulting in the Snowmass Mountain area. The types of structure at different positions along the zone of deformation may be considered illustrative of stages in the development of the Elk Mountain thrust. First, a monoclinal fold developed (see fig. 7, a), owing to uplift of the area on the east with respect to the area on the west. During this stage the vertical component of movement was important, and locally normal faulting, such as that near Placeta (fig. $7 ; e$ ), oceurred. In the seeond stage the horizontal component of movement became relatively more important, and the upper limb of the monocline was arehed into an anticline. Lastly the horizontal component became dominant as the beds broke along the line of flexing, and thrust movement was initiated along a surface essentially parallel to the bedding of the upper block (fig. 7, c). Each of the movements described represents the resolution of forces active during the period of development of Rocky Mountain structure.

\footnotetext{
Vanderwilt, J. W., The revision of structure and stratigraphy of the Aspen district, Colorado, and its bearing on the ore deposits : Econ. Geology; vol. 30, no. 3, p. 231, 1935.
} 

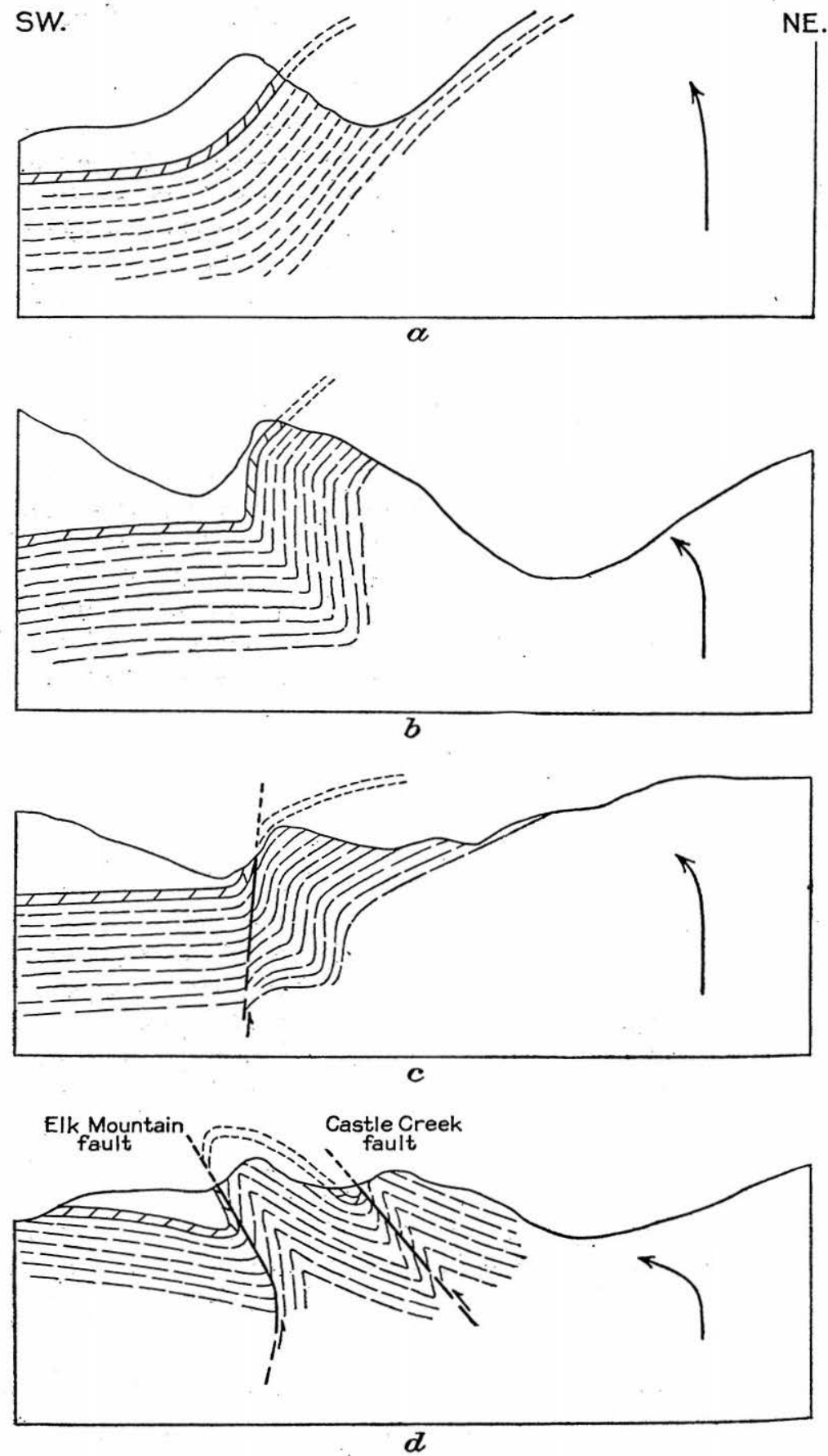

FrguRe 7.-Diagrammatic cross sections of structural types along the Elk Mountaip: Grand Hogback zone of deformation. Approximate positions of cross sections, $a, b, a$, and $d$, are shown in figure 6 . Arrows show relative amount and direction of movement $a$, Vertical component dominant; $b$ and $c$, horizontal component becoming important; d, horizontal component dominant, position of thrust faulting. 
Relative age.-Hayden ${ }^{88}$ in explaining the structure of the Elk Mountains says:

The Snowmass Range presents one of the most marked examples of the complete subversion of the strata by the elevation of the great group of granite peaks which formed the core of that range.

The following year Holmes ${ }^{64}$ in explaining the structure wrote:

It will be seen, by reference to the figure and the sections opposite [see pl. 1], that the conditions along the east side are simple, there being a gradual and gentle dip from the crest of the range toward the valley of Roaring Fork, while on the west side there has been a gradual depression or downthrow, so to speak, amounting in many places to 7,000 or 8,000 feet; at the same time a combination of movements, principally lateral, have produced along the axis an immense wrinkle, a fold so abrupt that the beds are crushed and shattered and the several edges shoved past each other, as shown in the drawing and sections between e and $n$. It will not be difficult to imagine that while this was going on, the plastic mass beneath was assisting the movements and shaping the results, and that during the process it forced itself, or was forced, through the fracture line in the two great masses of Snowmass and White Rock groups.

Hills ${ }^{85}$ about 16 years later agreed with Hayden and Holmes that the large intrusions of Mount Sopris and Snowmass and White Rock Mountains were contemporaneous with folding, even though he recognized the continuity of the structure to the northwest. He also believed that the Treasure Mountain dome was older and that subsequent to its formation it was tilted bodily by the uplift that resulted in the fault zone.

It is evident that the three intrusions of the Elk Mountains are alined along the regional structure. They apparently followed the line of weakness of the fault zone, which they also clearly intersect. South of Snowmass Mountain the granodiorite occurs along the surface of the thrust fault for fully 2 miles, and nowhere does the rock show any recognized effects of contemporaneous movement of the wall rock. West of this area the intrusive contact crossed the entire fault zone, which locally is wide, and forced its way beyond it for more than a mile into the weak Mancos shales. Just south of the limits of the area mapped, at the head of Rustler Gulch, the granodiorite of the White Rock Mountain group cuts abruptly across the fault zone in a similar manner. The crosscutting and the lack of faulting in the granodiorite indicate that the intrusion occurred after the final period of adjustment along the fault zone.

The age of the fault zone with respect to the Treasure Mountain dome has not been definitely established, but the field relations

\footnotetext{
EHayden, F. V., Geology of Elk Mountains: U. S. Geol. and Geog. Survey Terr. 7th Ann. Rept., p. 66, 1874.

Holmes, W. H., Report on the geology of the northwest part of the Elk Range: U. $\mathbf{8}$ Geol, and Geog. Survey Terr. 8th Ann. Rept., p. 68, 1876.

Sci. Soc. R. C., Orographic and structural features of Rocky Mountain geology : Colorado

Sci. Soc. Proc., vol. 3, p. 413, 1891.
} 
suggest that the dome is the younger. The evidence for this conclusion, included in the following description of the Treasure Mountain dome, is briefly as follows: The asymmetrical dips and faulting related to Treasure Mountain indicate that the regional dips of the sedimentary rocks formed by movements along the Elk Mountain fault zone existed before the dome was formed, and had there been any appreciable movement on the Elk Mountain fault zone subsequent to the formation of the Treasure Mountain dome late faulting in the dome would be expected.

\section{TREASURE MOUNTAIN DOME}

The general shape of the Treasure Mountain dome has already been brought out in the description of the form of the granite stock which is a part of it and to which it is due. (See pp. 48-50.) The part of the dome to be described further consists of the arched sedimentary formations. Its detailed form is of interest because it offers a clue to the relative age of the dome and it includes a system of faults that influenced the localization of sulphide mineralization.

SIZE AND FORM

The dome is elliptical in ground plan (see pl. 1) and covers approximately half of the western part of the Snowmass Mountain area. The long axis trends northwest and is parallel to the Elk Mountain fault zone, which bounds it on the northeast. The Snowmass Mountain intrusion limits the dome at its northwest end, about a mile northwest of Marble. The southwest flank grades into the regional southwestward-dipping beds found in the adjoining area of the Anthracite quadrangle. The southeast end extends under Schofield Pass, and southeast dips are continuous as far as Emerald Lake. A little below this lake there is a slight reversal of dip that forms a small sharp fold, beyond which the southeast dips continue for nearly 2 miles before they flatten and are reversed by the large intrusion of White Rock Mountain, in the Sawtooth Range. These extreme limits give the dome a length of about 12 miles and a width of 9 miles. The dimensions given, although necessarily somewhat arbitrary, are believed to express the proper order of magnitude.

The structure of the dome is well exposed by erosion. The smooth curves of the arched formations can be seen from almost every direction. A striking view, however, can be had from Sheep Mountain to the north or from the higher slopes farther north. (See pl. 16, A.) This view and one from the east (see pl. 16, $B$ ) show the parallel relation between the topographic form and the structure of the arched beds, which is one of the most striking features of the Treasure Mountain dome. 
The dips of the Jurassic and Cretaceous beds range between $40^{\circ}$ and $50^{\circ}$ along the lower part of Yule Creek and between $20^{\circ}$ and $30^{\circ}$ on the opposite side of the dome, along the Crystal River. The dips of the Paleozoic beds show an opposite relation $-30^{\circ}$ to $45^{\circ}$ along the Crystal River and $20^{\circ}$ to $25^{\circ}$ along the upper part of Yule Creek. This difference is to be expected with the angular unconformity between Jurassic and Paleozoic formations and accordingly is not particularly significant. The asymmetric dips of the younger beds are of special interest because they offer a clue to the relative age of the intrusion with respect to the Elk Mountain fault zone. These asymmetric dips can be explained theoretically by asymmetric uplift of horizontal Jurassic and Cretaceous formations, or symmetric uplift of the horizontal Jurassic and Cretaceous formations with subsequent tilting of the entire dome, but it is in reality caused by symmetric uplift after the Jurassic and Cretaceous formations had acquired regional dips of $10^{\circ}-15^{\circ} \mathrm{SW}$.

\section{FAUITS}

A series of parallel faults has been developed parallel to the long axis, and, with one exception, they are on the northeast flank of the uplift. On Galena Mountain, a small area between latitudes $39^{\circ}$ and $39^{\circ} 2^{\prime}$ and longitudes $107^{\circ} 3^{\prime}$ and $107^{\circ} 5^{\prime}$, the faults were mapped in detail on a scale of $1: 12,000 .{ }^{66}$ In this area excellent exposures of two unfailing horizon markers-the Dakota (?) quartzite and the limestone in the Morrison (Jurassic) formation-permitted the recognition of a greater percentage of the displacements than is possible outside of this particular area. There can be little doubt that faults extend from Galena Mountain to Crystal Peak and from Crystal Peak to Sheep Mountain, but owing to the absence of horizon markers the displacements are not evident. Except for the presence of Jurassic beds on Crystal Peak the faults there would probably not have been recognized. On Sheep Mountain they could not be traced far from the outcropping rim of Dakota (?) quartzite. The faults are mineralized, and this is often an aid in tracing them; but mineralization has also occurred along fissures showing no appreciable displacement. Likewise, few faults are mineralized for their entire length. Projection of faults is therefore difficult, and it is not safe to map a fault much farther than it can be traced. The habit and nature of the faults and fractures are important because mineralization is largely confined not only to the zone of faults but in most places to the fractures themselves.

Characteristic features.-The faults can be divided into two broad groups-one having relatively few fractures, which have large

\footnotetext{
" Vanderwilt, J. W., Preliminary geologic notes on Galena Mountain, a part of Snowmass Mountain area, Colo.: Colorado Sci. Soc. Proc., vol. 13, no. 1, pl. 1, 1932.
} 
displacements, and the other including numerous discontinuous fractures showing displacements of not more than 15 or 20 feet. The smaller fractures are as a rule branches of the larger ones or are otherwise related to them. North to northwest strikes, steep easterly dips, and normal displacements are invariably shown by the larger faults and prevail throughout the zone. Some of the smaller faults have steep westerly dips and normal displacements. Apparent reverse faults were also observed near the larger faults on the ridge south and southwest of Galena Lake, and these account for small intervening horsts or upthrown blocks.

The number of faults and the amounts of displacement decrease to the southeast of Galena Mountain and to the northwest in the vicinity of Lead King Basin and Sheep Mountain. Sharp drag folds are common, especially along the larger faults, and are the cause of numerous branching faults, which will be referred to as "drag faults." Drag faults are almost invariably present on the footwall side, but on the hanging wall, even where strong drag is evident, they are unimportant or absent. On Sheep Mountain several faults are accompanied by a noticeable change in strike and dip of the beds on each side of some of the fractures. Except on the very rim of Dakota (?) quartzite the faults are poorly exposed, and the relations are therefore obscure; but the sharp changes in strike and dip are believed to be due to drag faults.

The several features referred to are shown by the Whopper fault, the largest in the area (pl. 1). Other details common to the entire zone are also shown by the Whopper fault, which is therefore solected for a detailed description.

Whopper fault.-The Whopper fault is named after the Whopper mine, on Whopper Creek. Its strike ranges from about north where it is crossed by the. Brooklyn tunnel to fully $20^{\circ}$ west of north on Whopper Creek, and the dip is $70^{\circ}-80^{\circ} \mathrm{E}$. It is well exposed on the surface for a little over 3 miles. The hanging wall has moved down relative to the footwall, and the displacement attains a maximum of about 600 . feet in the vicinity of the Homestake tunnel, which follows the fault. The throw decreases both to the north and to the south. At each end the fault crosses limestone of Niobrara age, where the displacement is less than 50 feet, and beyond it is lost in the Mancos shales without any indication that it continues farther. A pronounced drag is shown in both footwall and hanging wall in the vicinity of the Brooklyn tunnel. Only on the footwall side, however, are drag faults present.

The drag faults branch from the main fault at angles of $15^{\circ}$ to $20^{\circ}$. They invariably extend to the northwest, and their displacement is greatest next to the main fault. At distances of 1,500 feet or less from the main fault the displacement has generally decreased to 
only a few feet, but a strong fissure usually continues for several hundred feet farther. It is common to find that a drag fault that is essentially vertical near its junction with the main fault changes to a dip of $60^{\circ}-70^{\circ} \mathrm{E}$. a short distance away from the fault. In addition, the strike curves so that the surface of a drag fault is slightly concave toward the main fault. Smaller fractures that branch from the drag faults are not uncommon. Some of the smaller fractures show displacement, and one or two were large enough to be shown on the map. The fractures are so numerous that it was considered impracticable to map those that do not show any displacement.

Lack of continuity.-The small fractures are not continuous in the Jurassic rocks. The faults immediately east of Galena Lake that offset the Dakota (?) quartzite from 5 to 20 feet cannot be traced in excellent glacially smoothed exposures of the Morrison formation, and the fractures are very inconspicuous in the quartzite. No evidence of extensions to the south in the Mancos shale could be found. Failure of faults to continue through the hornfels is interpreted to mean that the displacement occurred before the alteration of the shale-that is, the faults in the quartzite would be represented in shale by flexures or small fractures that were obliterated in the conversion of the shale to hornfels. Likewise the recrystallization of sandstone to a dense quartzite would tend to heal and make the fractures inconspicuous in this rock. This is in accord with the fact that faults are not found in the granite of Treasure Mountain; at the head of Yule Creek a fault was traced to a point within a few feet of the contact, but no sign of a continuation could be found in the granite.

Origin.-Maximum displacement nearest the crest of the dome and the fact that the displacement is such as would compensate the tension due to arching of the formations are regarded as proof that these faults were produced by the arching of the formations.

The presence of faults only along the northeast side of the dome is explained as follows: The granite of Treasure Mountain, symmetric in form, intruded and domed formations having a regional dip to the southwest, and consequently the strata on the northeast side of the uplift were folded so sharply that faulting resulted. On the southwest side of the dome the favorable regional dip made flexing without fracturing possible.

\section{RELATIVE AGE}

As the granite is younger than the dikes in the southern part of the area the dome also is younger. The dome is probably younger than the Elk Mountain fault zone, as it is superimposed on the regional southwest dips of the sedimentary formations, and the regional dips were produced by the diastrophism that formed the Elk Mountain fault zone. 
The age of the Grand Hogback fold, the northern extension of the Elk Mountain fault zone, has been established as post-Bridger, and accordingly the Treasure Mountain dome is younger. It is possible, however, that the two are contemporaneous, as there is some evidence that the movement along the fault zone in the Elk Mountains was earlier than the movement in the vicinity of the Grand Hogback and to the north. For example, the Wasatch (lower Eocene) appears to dip less steeply than the Mesaverde (Cretaceous) beds in the Anthracite quadrangle, whereas in the vicinity of the Grand Hogback a similar angularity was not recognized.

The relative age of the dome and the intrusion of Snowmass Mountain is not known. Both appear to represent the last phases of igneous activity in the area, and they may be genetically related; if so, the intrusions were essentially contemporaneous.

\section{SUMMARY}

The structural features of Tertiary age show a sequence of intrusion and folding with faulting. The earliest Tertiary structure within the area is marked by the northeast trend of the earlier dikes. After this the Elk Mountain fault zone was active, as indicated by the faulted dikes. Whether this activity was merely a renewal of movement or marked the initial movement of the fault zone is not known. Later than the disturbance that produced the Elk Mountain fault zone, apparently after its latest movements, came the intrusions of granodiorite of Snowmass Mountain and White Rock Mountain and the granite of Treasure Mountain. The structural features were all formed in post-Cretaceous time, and along the Grand Hogback, the northward continuation of the Elk Mountain fault zone, there has been considerable post-Bridger (middle Eocene) movement. The sequence of events is in accord with the general belief that the Tertiary structural features originated at successive intervals and through an appreciable span of time.

\section{GLACIATION}

The glacial features in the Snowmass Mountain area are like those found in nearly every other high mountainous area in central Colorado, and they indicate strong glacial action in the Elk Mountains. These features will be considered under two divisions-deposition and erosion.

\section{DEPOSITIONAI FEATURES}

\section{DISTRIBUTION AND RELATION TO TOPOGRAPHY}

Glacial deposits in this area are not extensive. They consist chiefly of erratic boulders and a few poorly developed lateral moraines at 
altitudes of 800 to 1,500 feet above the bottoms of the valleys. The floors of the valleys upstream are essentially free of morainic material. Below Marble the floor of the valley of the Crystal River consists of accumulations of soil and gravel, but moraines were not observed.

The distribution of the erratic boulders and moraines is shown on plate 1 (oversheet). Small lateral moraines occur at the west end of Sheep Mountain, northeast of Mineral Point, and also, though less well defined, on Yule Creek opposite the Yule Colorado marble quarry. At each of these places the moraines were found at altitudes of about 10,250 feet.

The erratic glacial boulders of granodiorite from Snowmass Mountain occur on benches or shoulders on the south slope of Sheep Mountain, which are ordinarily not clearly expressed by the contour lines on the map. Large blocks of hornfels of the Morrison formation were observed north of Marble and several hundred feet vertically above that village.

Boulders of white marble and gneiss 3 feet across that must have come from the vicinity of Treasure Mountain were seen 800 to 1,000 feet above the floor of the valley of Coal Creek opposite Redstone, about 12 miles down the valley northwest of Marble. Each variety of rock is readily recognized, and consequently little difficulty is encountered in locating the source of these glacial boulders. Several miles farther downstream and north of Redstone extensive gravel terraces, at altitudes of 500 to 800 feet above the stream; are believed to represent glacial outwash and therefore to mark the limit of the glacier that moved down the valley of the Crystal River. A brief reconnaissance did not reveal terminal moraines to mark this limit of the ice. As postglacial erosion has cut a valley about 500 feet deep and a quarter to half a mile wide, any moraine that may have been present would have been largely destroyed.

\section{EROSIONAL FEATURES}

\section{CIRQUeS, U-Shaped VALLEYS, AND LAKES}

The cirques with their precipitous walls at the heads of streams, the $U$-shaped valleys, the numerous lakes in rock basins, and the smooth, grooved surfaces of fresh bedrock are all indicative of recent mountain glaciation. Many examples of these features occur in the area. The cirques contain accumulations of talus, but rock streams have not developed. The cross sections of the valleys show the characteristic broad, shallow $\mathbf{U}$ shape. Below the junction of tributaries the depth relative to width and consequently the steepness of the walls are noticeably greater than in each branch some distance above the junction. A similar though less conspicuous relation is shown below the junction of the Crystal River and. Yule. Creek at Marble. 
Most of the lakes are of the rock-basin type. Emerald Lake, south. of Schofield, is partly dammed by talus, but the dam is shallow, and its removal would probably not drain the lake. Heavy timber conceals bedrock around the outlet of Big Snowmass Lake; however, bedrock is exposed only a few hundred feet downstream from the outlet. Lizard Lake is in a peculiar short valley transverse to the ridge that separates the Crystal River and Lost Trail Creek. This valley was formed by the ice flowing from the main valley of the Crystal River across the ridge and into Lost Trail Creek. Elko Lake represents a rock-bound basin tapped by a narrow postglacial channel. A plank dam across the channel impounds the water, making the lake as it now stands largely artificial. Little Snowmass Lake, Galena Lake, and the little unnamed lake high on the sides of Yule Creek Valley all have their outlets in solid rock. Numerous small depressions in : bedrock are found on the terraces or benches along the valley near the head of the North Fork of the Crystal River. These depressions contain water during the greater part of the year, but many are too small to be shown on a map of this scale.

Rock outcrops smoothed by the ice are numerous along the valleys, and glacial striae are common. Remarkably deep and permanent glacial grooves in a dip-slope surface of dolomite occur on the east side of Yule Creek a short distance southeast of the marble quarry. These grooves, shown on plate $13, B$, are cut parallel to the stream and are only a few feet above it, suggesting relatively little postglacial erosion in this locality.

\section{GLACIATED ROCK TERRACES}

Glacial rock terraces are very conspicuous at or near the heads of the valleys. The contour lines on the topographic map fail to bring out the prominence of the terraces, and several of the smaller ones are not shown at all. Some of the conspicuous glaciated terraces or rockcut benches are shown on plate 1 (oversheet). They are characterized by polished and striated rock surfaces, rock-basin lakes, and waterfilled depressions too small to be called lakes. The terrace shown on plate 17, $A$, is cut across Maroon red beds along a tributary of the North Fork of the Crystal River. A similar bench cut in gneiss is shown on plate $17, B$. Glaciated terraces, benches, shoulders, or spurs are not peculiar to the Snowmass Mountain area. They are well developed in the Sawatch Range and are particularly well shown at the head of Roaring Fork, west of Independence Pass. They are present almost everywhere in the San Juan Mountains, according to Atwood and Mather, ${ }^{87}$ who consider them features developed by stream erosion and later modified by the ice. Similar terraces in the European

\footnotetext{
en Atwood, W. W., and Mather, K. F., Physiography and Quarternary geology of the San Juan Mountains, Colo.: Geol. Survey Prof. Paper 166, p. 27, 1932.
} 
Alps ${ }^{68}$ have been interpreted as representing a stage of sluggish glaciation preceding the more active glaciation that carved the inner and relatively narrow U-shaped valley. The continuous slopes of rock smoothed by ice from the bench down to the bottom of the valley, shown on plate $17, B$, are considered evidence that glaciation of the benches and lower parts of the valley in this area was essentially contemporaneous.

\section{HANGING VALLEYS AND CIRQUES}

Hanging valleys and cirques are features so well known that they scarcely require description. Attention is called to the concordance of the valley occupied by Little Snowmass Lake with terraces at Mineral Point, northeast of Galena Lake, and east of benchmark 10360 in Schofield Park. (See pl. 1, oversheet.) To these features at altitudes of about 11,000 feet can be added the two hanging valleys at the head of the North Fork of the Crystal River. Although hanging valleys are found both higher and lower than 11,000 feet, those at this level stand out more prominently than the others. Hanging cirques are striking features on the north side of Treasure and Treasury Mountains, although they are not at all well brought out on the map.

\section{POSTGLACIAL Frosion}

As the rate of stream erosion varies greatly with the gradient, and as moving ice cuts a valley to an uneven gradient, a true picture of postglacial erosion is not easily obtained. This is well illustrated in the Snowmass Mountain area, where in places, particularly above the junctions of larger tributaries, there are deep, steepwalled canyons, but elsewhere only small channels. Above the junction of the North and South Forks of the Crystal River each branch has cut a sharp gorge about a mile long and 25 to 100 feet deep. Sharp postglacial canyons are likewise found above the junctions of Yule Creek, Lost Trail Creek, and the Crystal River. The canyon along the Crystal River is 100 to 200 feet deep, with vertical walls cut in the resistant Dakota (?) quartzite and the hard hornfels of the Morrison formation. The canyon of Lost Trail Creek, in rocks of the same kind, is equally sharp, though not as deep or wide. Along Yule Creek, with relatively soft Mancos shale at the lower part, the walls of the canyon are not vertical, but they are steep. These canyons represent headward cutting from the levels of the overdeepened valley below the junctions of tributary glaciers, and this fact must be taken into account in considering postglacial erosion. Along the Crystal River west of Crystal-that is, between

\footnotetext{
${ }^{\text {es }}$ Penck, Albrecht, The origin of the Alps : Am. Geog. Soc. Bull., vol. 41, p. 68, 1909.
} 
the sharp canyons referred to-the stream has cut less than 10 feet below the polished surfaces left by the ice. The glacial grooves along Yule Creek shown on plate 13, $B$, occur only a few feet above the stream. Along the Crystal River west of Marble the channel of the stream, even though in soft shale, is shallow, showing very little cutting since the ice filled the valley. The steep-walled, deep canyons therefore, represent a high rate of cutting due to the local and exceptional gradient left by glaciation. Taken as a whole postglacial erosion is slight and has not materially altered the glacial features.

\section{CONCLUSIONS}

Two stages of glaciation are evident several miles below the heads of the valleys, and continuous glaciation seems to have occurred near the higher divides. The earlier stage is represented by the glacial boulders found in several places 800 to 1,000 feet vertically above the valley and as far down as Redstone; the later stage is represented by the U-shaped valleys. This is in accord with Spurr's interpretation of the geologic history of the Aspen area, on the western flank of the Sawatch Range, ${ }^{69}$ and also with Capps' description of glaciation on the eastern flank of this range as well as in the Mosquito Fange. ${ }^{70}$ In the San Juan Mountains Atwood and Mather ${ }^{71}$ recog. nized three stages of glaciation with rather extensive interglacial stages.

In contrast to two entirely distinct stages of glaciation lower down the valleys, continuous glaciation occurred at the heads of the valleys near the higher divides, as is shown by the unbroken glacially polished rock slopes from the rock terraces down to the floors of U-shaped valleys.

\section{ORE DEPOSITS}

\section{GENERAL SUMMMARY}

Treasury Mountain owes its name to the mineral deposits recognized on it prior to 1876 . The first shipments of ore recorded were sent from the Eureka mine in 1883, and the next from the Black Queen mine about 1889. The North Pole and Lead King mines first produced about 1900 . The total production is not known, but the mines are small, and none of them produced continuously. The Lead King mine, according to authentic records, produced about $\$ 250,000$, chiefly in lead, and it is doubtful whether all other production would

Spurr, J. E., Geology of the Aspen mining district, Colo.: Geol. Survey Mon. 34 p. 245.1898.

${ }^{70}$ Capps, S. R., Pleistocene geology of the Leadville quadrangle, Colo.: Geol. Surver Bull. 386, p. 15, 1909 .

"1 Atwood, W. W., and Mather, K. F., Physiography and Quaternary geology of the San Juan Mountains, Colo. : Geol. Survey Prof. Paper 166, p. 82, 1932. 
equal this amount. The production of individual mines, as far as it is known, is included in their descriptions below.

The marble industry on Yule Creek has been and promises to continue to be commercially more important than mining. The marble is recrystallized Mississippian (Leadville) limestone. A small quantity was marketed in 1896, and almost continual annual production has been made since 1908. Building stone has no logical place in the description of sulphide minerals and therefore the marble deposits are described separately after this section on ore deposits.

The ore consists of the base-metal sulphides, silver, lead, copper, and zinc. Invariably it has been referred to in the literature as "lead-silver ore", which, however, is only an expression of the greater economic interest in this particular ore. On the basis of quantity produced, zinc and lead ore with a minor amount of silver from the Lead King mine predominates. Next in order are silver from. the Black Queen mine and copper-silver ore from the North Pole mine. These three types of ore are not representative of the deposits as a whole, because with relatively few exceptions all the prospects show sphalerite, chalcopyrite, and galena in fairly uniform proportions, and silver is not always present in commercially important amounts.

Mineral deposits are concentrated on the northeast side of the Treasure Mountain dome in a faulted and fissured zone that extends from Sheep Mountain on the northwest to Galena Mountain on the southeast. This zone is 1 to 3 miles wide and about 8 miles long and contains sedimentary beds of Pennsylvanian, Permian, Jurassic, and Cretaceous age. The granite of Treasure Mountain also extends into this zone. The intrusion of the granite formed the dome, and in the vicinity of the mineralized zone it has cut out the early Paleozoic beds, which, however, are present on top of the dome and to the southwest. Prior to ore deposition all the sedimentary rocks were metamorphosed by the granite, which itself was unaffected. The Yule Colorado marble is a product of metamorphism.

The characteristic occurrences of the sulphides are in veins and bedded replacement deposits.

Quartz is the predominant gangue mineral in the veins, and small amounts of fluorite are invariably present. Manganiferous hedenbergite is abundant in places, and small amounts of barite and calcite are found locally. Pyrite is usually present in appreciable amounts, and in the vicinity of Galena Mountain specularite is plentiful in the massive quartz veins. The economic sulphides sphalerite, chalcopyrite, and galena occur together but in varying proportions. Tetrahedrite is common in small amounts, but native silver has been recognized in only a few places. Gold occurs only in minor amounts, and economically it is less important than the other metals. 
The minerals occur virtually in all proportions, but in the larger veins, some 40 feet wide, the bulk of the filling is quartz .with pyrite or hematite. Quartz veins are particularly numerous and conspicuous in the Dakota (?) quartzite and to some extent in other quartzite beds, but few of the larger quartz veins contain concentrations of sulphides of possible commercial value, and the deposits generally pinch out on passing into shale (hornfels). It is estimated that fully 90 percent of the explored veins are in or very near the Dakota (?) quartzite.

The mineralogy of the bedded deposits is similar to that of the , veins except that the beds do not contain the massive bodies of quartz common to veins, and specularite is much less abundant. The deposits are irregular in form, usually found along calcareous beds and in places localized along the intersection of a fracture and a bed. Some deposits are intermediate in form between bedded deposito and fissure veins.

Considered broadly a complete history of the mineralization includes the following three major divisions, each of which grades into the succeeding one: (1) Intrusion of granite, which also caused the faulting and the metamorphism of the country rock; (2) deposition of large amounts of quartz, locally with much pyrite, some specularite (hematite), and barite; (3) deposition of sphalerite; chalcopyrite, galena, and silver-bearing tetrahedrite (gray copper) with pyrite, fluorite, quartz, and calcite. The evidence of relationship between the first and second stages is suggested, first, by the fact that there has been more than average metamorphism, including the development of tourmaline, where faults are large and numerous, and second, by the presence of hedenbergite, one of the common and characteristic metamorphic minerals, intergrown with quartz in several veins.

The second and third stages are more directly and obviously related than the first two. The beginning of the third stage was marked by renewed movement along many of the older fractures, which shattered the quartz filling and afforded further access to the mineralizing solutions. Repeated reopening of the veins may have taken place during the second period. The distinctly banded character of the quartz veins may be due to repeated filling of successively formed openings, but as there is no essential difference in the character of the material deposited the detailed history has been obscured. During the third stage reopening of veins occurred again after some of the economic sulphides were introduced; they are locally veined by quartz. The mineralizing solutions were siliceous in all three divisions.

It appears that the prospectors preferred conspicuous quartz veins to the less conspicuous exposures of bedded deposits. However, the 
Eureka and Black Queen ores occurred along sedimentary beds in which no large fractures were evident, and the Lead King ore came from the intersection of a relatively small vein and limestone of Niobrara age. It is concluded that bedded deposits are more favorable for prospecting than veins and that exploration of veins deserves little encouragement except at their intersections with calcareous beds known to be favorable for ore.

\section{MINERALS}

The minerals found in the veins and bedded deposits are discussed briefly in alphabetic order.

Adularia $\left(\mathrm{KAlSi}_{3} \mathrm{O}_{8}\right)$.-Adularia was found in abundance in one thin section of a quartz vein in the Mancos shale east by south of the Brooklyn tunnel. The mineral was not observed elsewhere, but it does not seem likely that the occurrence is entirely confined to this locality. It was intimately associated with quartz and considerable fluorite, but sulphides were not present. In hand specimens adularia is not conspicuous and may be readily overlooked.

Aragonite $\left(\mathrm{CaCO}_{3}\right)$.- Radiating needles of aragonite occur in small amounts on chalcocite and line some of the cavities of calcite in the ore body of the Black Queen deposit. Aragonite was not observed elsewhere, and the small amount found in the Black Queen did not afford the opportunity to determine any genetic sequence or significance.

Argentite $\left(\mathrm{Ag}_{2} \mathrm{~S}\right)$.-Claims have been made that silver sulphide is present, but none was found in the course of this study in the area. It is reported in the Painter Boy mine, in the head of Washington Gulch just south of this area, and in mines in Rustler Gulch, in the White Rock Mountains.

Barite $\left(\mathrm{BaSO}_{4}\right)$.- Several prospects in the saddle southwest of Galena Lake and in the dump of the Inez tunnel west of Crystal show barite in quartz veins, and in places it is intergrown with specularite (hematite). This relation and the fact that it has not been recognized as a gangue with the later sulphides prove fairly well that barite preceded them. It is not present in sufficient quantity to be of commercial interest.

Calcite $\left(\mathrm{CaCO}_{3}\right)$ - - Calcite is the chief gangue mineral in some deposits and is entirely lacking in others. It may be looked for in any vein but is more characteristic in the deposits that occur on the outer fringe of the mineralized area as outlined above. In the ore of the Lead King and Black Queen mines calcite is the chief gangue mineral. It is usually white, either coarse- or fine-grained, and in places weathers to brown and black surfaces, indicating manganese and iron content. Commonly calcite in the form of scalenohedrons lines cavities or vugs. 
Irregular stringers and streaks of calcite are also common everywhere in the Mancos shale. This calcite seems to have been formed by a recrystallization of the calcite originally in the shale and is not related to sulphide mineralization. As a rule these calcite veinlets are too small to attract prospectors, but in one place a relatively large stringer was followed by a short tunnel. The calcite pinched out in a few feet and showed no sulphides.

Cerusite $\left(\mathrm{PbCO}_{3}\right)$.- Lead carbonate has been found or reported only in minor quantities. The characteristic lath-shaped water-clear crystals occur in the cavities of ore near the surface.

Chalcocite $\left(\mathrm{Cu}_{2} \mathrm{~S}\right)$.-Chalcocite is present only in small amounts, and it is rarely observed megascopically. On polished surfaces small areas of chalcocite replacing chalcopyrite are commonly seen. The chalcocite may therefore be a relatively important contributor to the copper content of chalcopyrite but by itself does not constitute an important ore mineral.

Chalcopyrite $\left(\mathrm{CuFeS}_{2}\right)$. - Chalcopyrite in small amounts is widely distributed in the veins, and it is conspicuous in the blanket deposits of the Eureka and North Pole mines. It occurs in fine specks in some of the sphalerite, and it is intergrown with both sphalerite and galena, suggesting contemporaneous deposition. There is no indication that chalcopyrite has associated with it either silver or gold.

Chrysocolla $\left(\mathrm{CuSiO}_{3} .2 \mathrm{H}_{2} \mathrm{O}\right)$. - The green copper silicate, superficially resembling malachite, occurs in several places. It is particularly common in veins on the east face of Crystal Peak, and it is also common in the North Pole mine. Chrysocolla does not constitute an ore mineral.

Fluorite $\left(\mathrm{CaF}_{2}\right)$.-Fluorite is widespread in its occurrence and may be considered one of the most characteristic and persistent of all the gangue minerals. It was found in every prospect that was examined in detail. As a rule the fluorite is colorless, and it is either mixed with the sulphides or lines cavities.

An abundance of fluorite was observed only in the Lead King mine, but here the relation of the fluorite to the sulphides does not appear to differ from that given above. In this mine the fluorite is coarsegrained, and it ranges from colorless to green and also from colorless to a deep pink.

Galena $(\mathrm{PbS})$ - - Galena is widespread in small amounts and in places constitutes ore. In places it is closely associated with sphalerite and chalcopyrite. Poorly crystallized galena occurs on the walls of the cavities (see pl. 18, $B$ ), and it occurs in the central part of the sulphide bodies, suggesting deposition during the later part of the period of sulphide mineralization.

It is commonly assumed by prospectors that the galena in the area is silver-bearing. Silver is generally present in some form, but the 


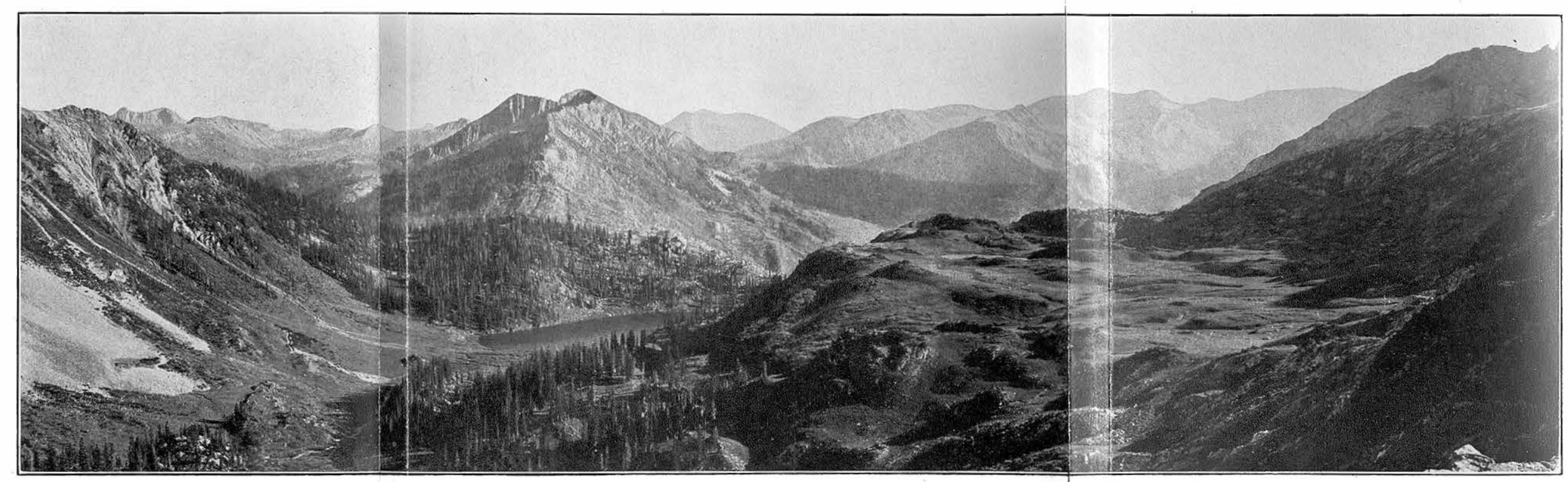

A. GLACIATED BENCHES ON MAROON RED BEDS NORTHWEST (RIGHT) AND SOUTHEAST (LEFT) OF LITTLE SNOWMASS LAKE.

Similar benches can be seen in the distance both to the left and to the right of Mineral Point (the peak that shows strata standing on end). The altitude of this peik as shown on the topographic map is 12,503 feet. The view is from the north.

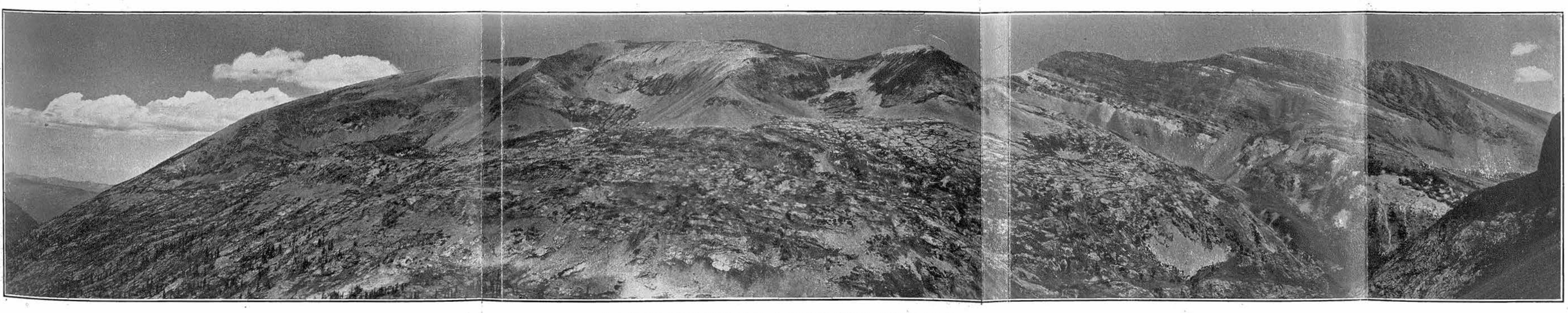

B. GLACIATED BENCH CUT IN GNEISS ALONG YULE CREEK.

On this hench are three rock-hasin lakes. (See topographic map, area south of Treasure Mountain.) View from south. 


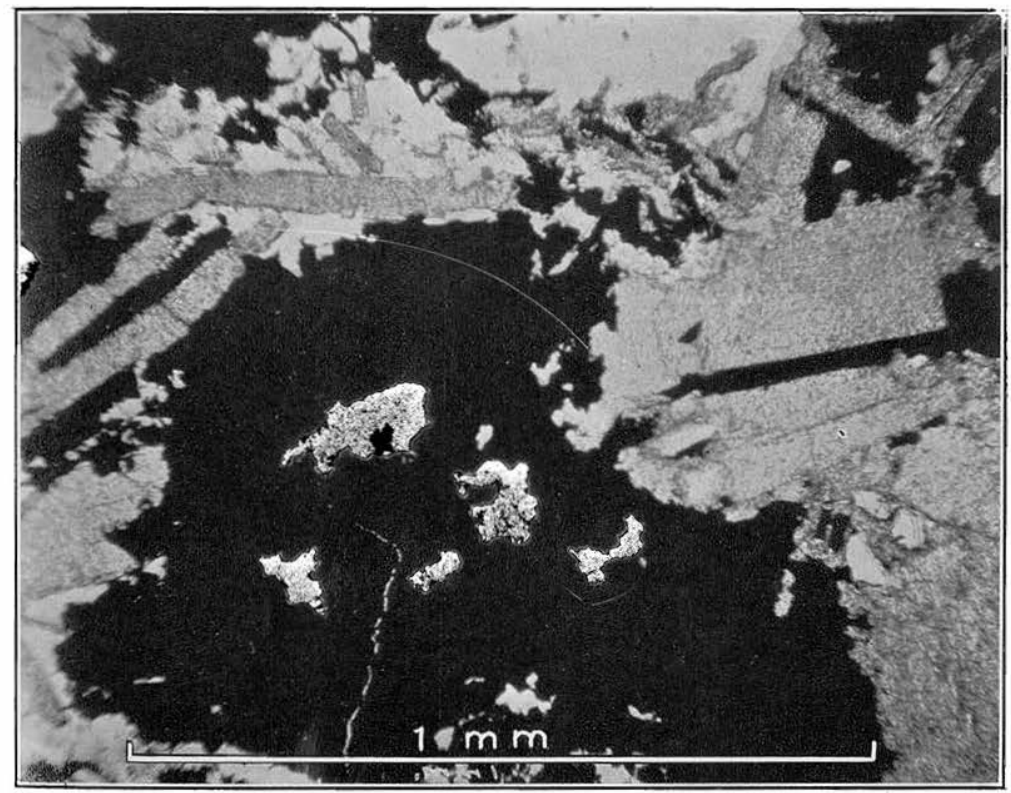

A. INTERGROWTH OF SPECULARITE (BLACK) AND BARITE (GRAY).

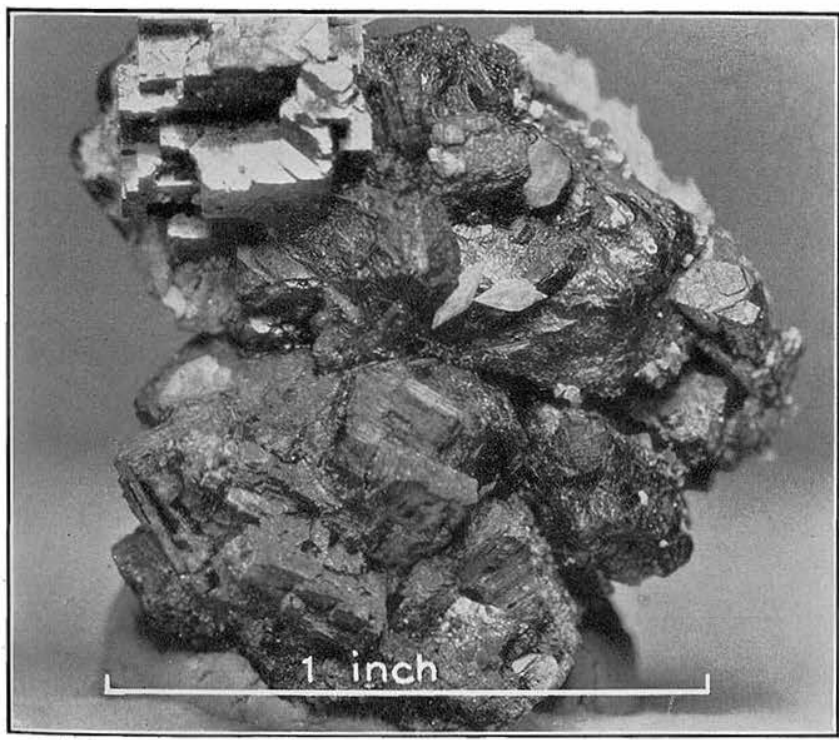

B. POORLY FORMED GALENA CRYSTALS FROM A CAVITY IN SPHALERITE, Lucky Boy tunnel. 


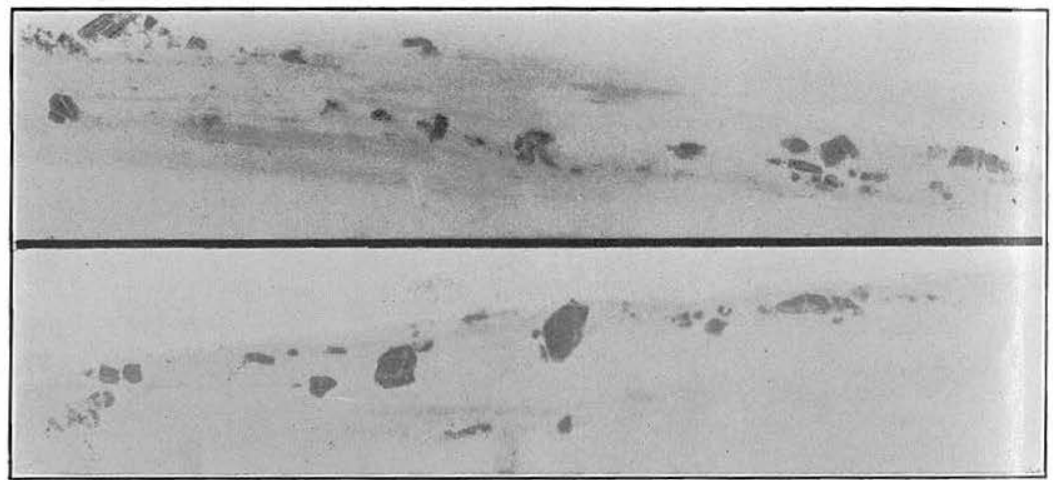

A. STRINGERS OF ANGULAR CHERT FRAGMENTS.

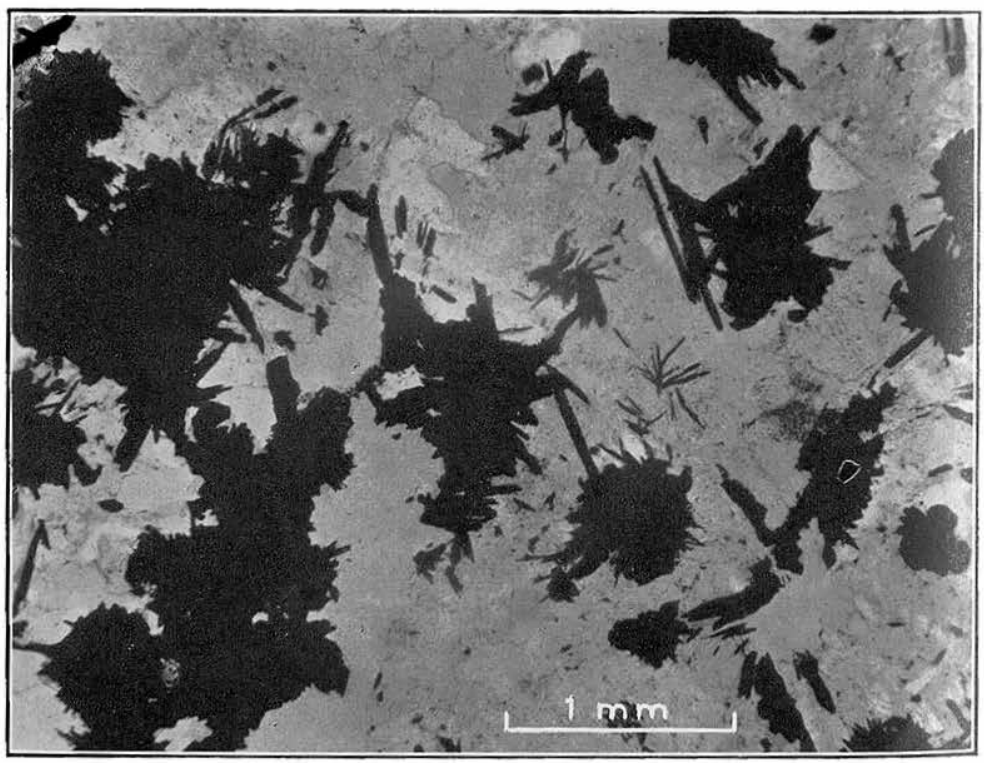

B. SEGREGATIONS OF SPECULARITE (BLACK) IN QUARTZ (GRAY). 
amount of galena is not an indicator of the amount of silver that may be expected. The rich silver ores of the Black Queen have relatively little galena in them, and the high-grade galena ore from the Lead King mine contained only a moderate amount of silver.

Gold $(\mathrm{Au})$.-Gold has not been important as an ore mineral. Many claims of high gold assays are made, but of 10 representative samples selected from as many veins by me and assayed at the Colorado School of Mines, only one showed an assay for gold and that only 0.02 ounce to the ton. G. Sessinghans ${ }^{72}$ from many assays had one that ran 0.3 ounce and the rest showed either nothing or less than 0.02 ounce to the ton. H. W. C. Prommel ${ }^{78}$ obtained an assay of 0.32 ounce from hand-sorted ore high in gray copper. C. C. McWilliams, of Marble, discovered a small quartz vein southeast of Lizard Lake in some of the vugs of which a small amount of native gold was found. This occurrence is obviously exceptional, and any claims of gold ores in the area should therefore require careful verification.

Hedenbergite (iron-bearing pyroxene).-Hedenbergite is readily recognized by its almost fibrous radiating structure. It is green on fresh surfaces and commonly black when weathered. Qualitative tests show the presence of appreciable amounts of manganese, which accounts for the black color of the weathered surfaces.

Hedenbergite is a characteristic metamorphic mineral in the area, associated with garnet as a product of alteration that clearly preceded the sulphide mineralization. It is also abundant as a gangue mineral in some veins and bedded deposits, particularly on Galena Mountain and in North Pole Basin. The relation of this mineral to the sulphide mineralization is not clear. As a rule it occurs in bands in massive quartz parallel to and along the walls of a vein. These bands do not appear as deposits along fractures but rather as if formed contemporaneously with the quartz. An early deposition of hedenbergite is suggested by its occurrence along the walls. This conclusion is supported by the fact that it was found to be cut by veinlets containing specularite, also an early mineral. As hedenbergite is a characteristic and common metamorphic mineral in the area, its presence in these deposits is interpreted as representing a transition between the contact metamorphism of the area and the formation of true veins.

Malachite $(\mathrm{CuOH})_{2} \mathrm{CO}_{3}$. - The green carbonate of copper is common as stains and superficial coatings on weathered surfaces of copper-bearing ores. The amount of malachite stain is not a fair indication of the relative copper content of a deposit, because a very small amount of the mineral will produce a very showy effect. Mala-

\footnotetext{
a Personal communication.

${ }^{73}$ Private report.

131028-37-8
} 
chite is of no commercial importance in the area except possibly as an indicator of mineralization to aid in prospecting.

Molybdenite $\left(\mathrm{MoS}_{2}\right)$.-Molybdenite is not common and was not observed in any of the veins that carry sphalerite, chalcopyrite, and galena. It occurs in a small quartz vein in the gneiss, and a few flakes were noted near the contact in the granite of Treasure Mountain. Both occurrences are near the head of Yule Creek, and the amounts of molybdenite are too small to be of economic value.

Pyrite $\left(\mathrm{FeS}_{2}\right)$.-Pyrite is the most common sulphide present, and it is found everywhere, not only in the ore deposits but also disseminated through the country rock, particularly in the metamorphosed shales. Without exception the pyrite has been found to be barren. It occurs both as an early and as a late mineral in the fissure veins and bedded replacement deposits. The earlier pyrite is coarse to massive, and where later sulphides have been introduced it shows fractures filled with the later minerals. Pyrite is also veined and replaced by specularite.

The later pyrite, in small but well-formed cubes and invariably in association with quartz; is found in veins that cut the earlier pyrite and specularite. It is also in intimate association with the sulphides of economic importance. Like the earlier pyrite it is barren.

Pyrrhotite (FeS).-Pyrrhotite in grains less than 1 millimeter across wasnoted locally in Morrison hornfels and in dolomite marble. Identification is based on microchemical tests and the fact that the grains are magnetic. There is no apparent association between the pyrrhotite and the veins, and it is probably a product of metamorphism.

Quartz $\left(\mathrm{SiO}_{2}\right)$-Quartz was one of earliest minerals to form and also one of the latest. Although it is the most abundant vein filling it is lacking in some deposits-for example, the Lead King, one of the most productive deposits in the area. In most veins the quartz is coarse-grained; and well-formed crystals lining the walls of cavities or open fractures are common. In the Black Queen mine jasperoid quartz is an abundant gangue mineral, but this is the only ore deposit in which jasperoid was noted. White jasperoid devoid of sulphides is conformable with the bedding of the Pennsylvanian formation at the head of Yule Creek.

Silver $(\mathbf{A g})$.- Native silver is reported in several localities, but it was found only in the Black Queen mine, where it is of economic importance. The silver occurs in two forms-(1) wire silver lining and filling small cavities in masses of pinkish-white calcite and (2) small plates attached to the walls of small seams or joints in black metamorphosed shale. The wire silver in the cavities of white calcite makes striking specimens, and it is claimed that this form of the metal constituted the principal ore However, at the time I examined 
the mine (1933) the plates of native silver along fractures in black shaly hornfels were much more conspicuous than the wire silver.

Specularite $\left(\mathrm{Fe}_{2} \mathrm{O}_{3}\right)$.- Specularite, the crystalline form of hematite, is very common throughout the area both as a metamorphic mineral and as a vein mineral. As a metamorphic mineral it occurs scattered through all the ferruginous sedimentary rock in individual grains, in veinlets as thin as tissue paper, and in irregular segregations along bedding planes. In the lower part of the Jurassic rocks. apparently along a certain horizon, paper-thin segregations of specularite in the form of rosettes 1 to 2 inches across are common along bedding planes. The specularite formed by metamorphism is in places associated with epidote.

In veins specularite is abundant in the area that includes Galena, Treasury, and Crystal Mountains. The well-formed shiny crystals in white quartz attract the attention of prospectors and are sometimes mistaken for galena. Specularite occurs as disseminated crystals or clusters of crystals in massive quartz (see pl. 19, $B$ ) and partly fills vugs in vein quartz, where it forms spongy rather than massive aggregates. In places this spongy or drusy specularite is very common, and locally it is more abundant than the quartz in the vein.

Specularite was deposited before sphalerite, chalcopyrite, and galena, as it is intersected by veinlets containing these sulphides. Veinlets bearing quartz and specularite cut quartz with pyrite, indicating that it was one of the last minerals to be deposited before the economic sulphides were introduced. The intimate intergrowth of barite and specularite (pl. 18, $A$ ) indicates that these two minerals came in at about the same time, and as both also occur in the vugs they are regarded as late minerals of the earlier period, during which the massive quartz filled most of the open fissures.

Sphaterite $(\mathrm{ZnS})$.-Zinc sulphide is present in most of the mineral deposits. It is generally more abundant than any of the other sulphides except pyrite. The color ranges from almost black, as on Yule Creek, through a deep resinous brown, as in the Lead King mine, to a clear yellow, as in the Black Queen mine. In most of the deposits sphalerite of the darker variety predominates.

On polished surfaces the sphalerite invariably shows numerous small inclusions of chalcopyrite, and it is intimately intergrown with chalcopyrite and galena deposited contemporaneously. Here and there sphalerite is cut by veinlets of the other two sulphides, showing that some of the chalcopyrite and galena was deposited after some of the sphalerite.

Tetrahedrite $\left(4 \mathrm{Cu}_{2} \mathrm{~S} \cdot \mathrm{Sb}_{2} \mathrm{~S}_{3}\right)$. - Gray copper is present in small amounts in many of the deposits. It is regarded as an indication of a high silver content in any deposit in which it is found, but this is not a safe generalization, as the results of qualitative tests for 
silver in tetrahedrite from different deposits ranged from very weak to fairly strong. In any particular deposit there appeared to be little variation. As a rule tetrahedrite is a silver-white mineral, but a dark-colored tetrahedrite, resembling argentite or chalcocite in color, was also found and gave a stronger qualitative test for silver than the lighter-colored varieties.

The mineral is present in only small amounts, and specimens showing definite age relations with other sulphides were not found. However, the general intimate associations indicate that it was deposited at the same time as the other sulphides.

\section{CHARACTER}

Mineralogically, particularly as regards the ore minerals, the ores of both the well-defined veins and the replacement deposits are approximately the same, but specularite and massive quartz are more conspicuous in veins than in the bedded deposits. Although the area is generally referred to as a producer of lead-silver, the ores are of the base-metal sulphide type. The lead-silver ores naturally attracted the attention of prospectors, whereas the quantitatively predominant lead-zine ores have not been emphasized.

The veins of massive quartz have not been productive. The quartz itself is barren, and the sulphides occur in the quartz as irregular or narrow lenticular stringers that pinch out and reappear repeatedly in a short distance. This pockety character of the sulphide bodies in the veins is an unfavorable feature for economic development of the deposits. However, these sulphide veins and the quartz veins are so conspicuous and relatively so numerous that in the future as in the past they will continue to attract the less discerning prospectors.

Mineralization, not including metamorphism, has been essentially confined to the zone of faults along the northeast flank of the Treasure Mountain dome. This zone extends from Sheep Mountain and Lost Trail Creek on the northwest to a point slightly beyond Paradise Pass on the southeast. Northeast of this zone mineralization has not occurred far beyond the outcrop of the limestone of Niobrara age in the Mancos shale. The southwestern boundary of the zone is irregular and approximately follows a line extending from the head of Yule Creek across Crystal Peak to Marble. Only two mineral deposits, those of the Skyline prospect and a prospect in Yule Creek about a mile southeast of the marble quarry, lie outside of this boundary. However, the character of the sulphides and gangue minerals found in these two places suggests their relation to the deposits in the main zone of mineralization. Small segregations of magnetite are found near the contact of the Snowmass Mountain intrusion, but sulphides other than pyrite disseminated locally through the metamorphosed sedimentary rocks were not observed. 
Oxidation is very shallow, as is characteristic of most glaciated areas. All outcrops of sulphides are stained with limonite, but the stain is superficial, and sulphides are common at the surface.

\section{VEINS}

The veins occur along faults and related fractures, and the vein minerals were introduced in two fairly distinct stages separated by an interval of fissuring. During the first stage of deposition of quartz varying amounts of pyrite, specularite, and some barite were deposited, and after a period of fissuring sphalerite, chalcopyrite, galena, small amounts of tetrahedrite and native silver, and pyrite with a gangue of calcite were introduced. The quartz veins, formed during the earlier period, range in width from a fraction of an inch along joints to 50 feet in places along the Whopper fault. In these veins vugs lined with relatively large quartz crystals are characteristic. Specularite and pyrite are unevenly distributed, and they are more commonly disseminated through the quartz; they also occur, specularite in particular, on the quartz prisms that line the vugs.

The second stage of mineral deposition followed a period of shearing which reopened some of the older quartz veins and also produced new fractures apart from the older ones. Thus the older quartz veins may or may not contain stringers of the ore minerals, and ore minerals are also concentrated in veins with little or no quartz. The sphalerite, chalcopyrite, and galena veins proper are very irregular in width, usually less than 6 inches. Although the several sulphides occur together, their proportions are not constant; it is common to find any one sulphide predominant in a given vein. The gangue minerals are quartz, calcite, and fluorite. Fluorite is persistent in its occurrence, though nowhere present in large volume, but quartz and calcite may occur in relatively large amounts or be entirely lacking.

The structure of the quartz veins is generally massive, although banded quartz and specularite occur in places. Banding is more characteristic of the ore. The most common arrangement, from margin to center, is quartz, sphalerite, chalcopyrite, and galena. Quartz, fluorite, and calcite, where present, are usually found along the more central part of the veins.

There is no apparent alteration of wall rock or its replacement by the vein minerals. The most prominent quartz veins are in the Dakota (?) quartzite or, as along the Whopper fault, bordering the quartzite, and they pinch down to insignificant width or disappear entirely in the overlying Mancos and underlying Morrison shales. The lack of replacement of wall rock and the general occurrence of prominent veins in quartzite, where open fractures would commonly form, are interpreted to mean that the quartz veins formed along open fissures. 
In order to explain the absence of quartz veins in hornfels, it can be assumed that initial fissuring and faulting occurred before the hornfels was formed; fissures in the shale would be sealed and obliterated by contact metamorphism that changed the shale to hornfels. Fissures in quartzite and the harder grits survived metamorphism and became the channels for the solutions that formed the veins. Subsequent shearing which preceded the introduction of the sulphides and which fractured the early quartz veins also fractured the hornfels. Consequently the ore sulphides are found in all the formations, regardless of their original competence to maintain openings. The bearing of these structural and genetic relationships on the problem of finding ore is obvious.

\section{BEDDED REPLACEMENT DEPOSITS}

The bedded replacement deposits include all those formed parallel or nearly parallel to the bedding. The ores in the Eureka, North Pole, and Black Queen mines are replacement bodies along beds, and those of the Lead King mine and Mexican Cut occur along the intersection of a relatively poorly defined fracture and a bed. All the larger deposits are in this group, and the stratigraphic horizons at. which they occur range in age from Devonian to Cretaceous, as shown in the following table:

\section{Cretaceous :}

Limestone of Niobrara age in Mancos shale:

Jurassic : Lead King mine.

Limestone 50 to 60 feet above base of Morrison formation: Mexican Cut.

Entrada sandstone (as mapped, may include some areas of sandstone of Morrison age) :

Prospect at head of Yule Creek.

Permian and Pennsylvanian (?):

Maroon formation, calcareous beds:

Black Queen mine.

Eureka mine.

Pennsylvanian:

Hermosa (?) formation:

Mississippian:

North Pole mine.

Leadville limestone, lower part:

Devonian: Stkyline mine.

Chaffee formation; Parting member: Prospects in Yule Creek.

The bedded deposits contain the same suite of minerals that is found in the veins, and their occurrence is also similar. Quartz is less abundant, and nowhere is it present in massive bodies comparable in size to the larger quartz veins. It is entirely lacking in the 
Lead King mine, and it occurs as jasperoid in the Black Queen mine. In the Eureka and North Pole mines quartz is more plentiful. The North Pole ore body, more than any of the other bedded deposits, resembles a vein not only in the volume of the quartz but also in the banded and vuggy character of some of it. These features were not observed in any of the other bedded deposits.

The form of the ore bodies is as a rule irregular, owing to the uneven and incomplete replacement of particular beds. Most of the replacement deposits are in limestone or calcareous beds, but a few also occur in quartzite. It seems that in places the solutions followed bedding planes and spread into the rocks on each side. In other places the solutions followed a fractured bed, and replacement spread out from the fractures.

The extent of the bedded deposits is not known. In the North Pole mine a bed of ore is developed along the tunnel for a length of about 150 feet and an average width of 2 to 3 feet; in the Black Queen mine a greater length but less width is indicated. In the Lead King mine the ore lies along the intersection of a vein and a bed, and its horizontal dimensions are relatively small compared with its known vertical extent of about 200 feet. In each of these bedded deposits there is a possibility of a continuation beyond the explored limits, and in general the volume of mineralized rock is appreciably greater than in any of the explored veins.

\section{GEOLOGIC CONTROL}

For the convenience of the reader, the following discussion assembles and summarizes information that is scattered through the preceding sections of the report.

\section{FAULTING AND METAMORPHISM}

The formation of the mineral deposits was dependent on the existence of fractures that afforded access to solutions. This was particularly true during the early history of mineralization, when barren quartz filled the existing openings. The walls of these veins are sharply defined and show little or no replacement of wall rock, thus indicating that the solutions were not of the penetrating type that could pass through the pores of the rock. Under these conditions replacement would be proportional to the size and number of fractures in crushed or fissured zones.

The extensive metamorphism is believed to have a bearing on the problem. Faulting, metamorphism, and mineralization were all produced by the granite intrusion, and they occurred in general in the order mentioned. Metamorphism therefore had an opportunity to destroy some of the earlier fractures, especially in such rocks as shale, calcareous shale or sandstone, and limestone, in which exten- 
sive recrystallization occurred. The surviving openings are found in the harder rocks, such as quartzite, and they are generally marked by quartz vein filling. The last period of shearing, which reopened many of the quartz veins, had an opportunity to affect all the metamorphosed rocks, including the calcareous rocks, and it prepared the way for the solutions that brought the ore. Virtually all the replacement deposits are related to fractures that originated during this later period of fissuring.

The larger concentrations of earlier quartz occur along the larger faults and near the junction of branching fractures. Furthermore, the quartz veins are generally in quartzite beds, and as the quartzite beds make good outcrops these quartz veins are so conspicuously exposed that they naturally have attracted much attention. The quartz veins are not, however, a favorable indication of ore, as the ore is dependent on later fractures, which are not confined to the early quartz veins or to the quartzite beds. The ore sulphides occur in veins and in bedded deposits formed by replacement, which is as dependent on the physical character and composition of the country rock as it is on the fracturing in the rock.

\section{CHARACTER AND COMPOSITION OF ROCK}

The more promising sulphide deposits are accompanied by an appreciable amount of replaced rock and occur in limestone and calcareous sandstone or shale. This relation seems to have been controlled by the manner in which these rocks fracture and by their solubility. In the Lead King mine the walls of the stopes show many intersecting veinlets of the sulphides, and the main body of the ore is reported to have been mostly a stockwork of veins with local massive bodies of sulphide. The amount of replacement cannot be determined, but the fracturing of the limestone and calcareous shale was obviously an important factor in permitting an infiltration of the solutions. In other mines replacement bodies of sulphides have formed at different stratigraphic horizons and in almost every variety of calcareous rock, but they do not occur in shale. The Lead King mine and the prospect called Mexican Cut are in limestones, whereas the Black Queen, North Pole, and Eureka are in more siliceous though still calcareous beds. Mineral deposits along a bed of quartzite of the Parting member are found in two places on Yule Creek. This mineralized stratum has attracted prospectors, but commercial ore bodies have not been found. The openings show that the sulphides are not strictly confined to the bed of quartzite, as they also occur along its contact with the overlying calcareous shales. A similar situation would be expected in the Pennsylvanian limestone beds and calcareous rocks within the mineralized zone. However, the beds at this horizon are not well exposed within the faulted zone, and they have not been fully explored. 
Pronounced zoning was not recognized in the mineralized zone along the northeast side of the Treasury Mountain dome. The only two mines from which there has been a regular commercial production of silver within the mineralized area are the Black Queen mine, near the northwestern limits of the zone, and the Painter Boy mine, at the southeast end. The Painter Boy is at the head of Washington Gulch, a few miles beyond the limits of the Snowmass Mountain area, just southeast of Cinnamon Mountain. In both of these mines lead and zinc are not quantitatively important as ore minerals, and calcite instead of quartz is the outstanding gangue mineral. The sulphide deposits occurring between these two mines-that is, from Paradise Pass to Crystal Mountain-consist of zinc-lead ores and are associated with much quartz. The ore at the Black Queen occurs in the Maroon grits, and that at the Painter Boy is related to the contact of a quartz monzonite sill in Mancos shale. The influence of wall rock or any other recognized factors cannot well account for the localization of the silver. Without doubt zoning offers the best explanation of the distribution referred to, but the number of deposits relative to the size of the mineralized area is so small that only a tentative conclusion is justified.

\section{CONCLUSIONS}

As the metals of chief value in the deposits are silver, lead, zinc, and copper, the ore bodies must be of considerable size and be favorably located for profitable mining. With one or two possible exceptions, the veins, as shown in numerous tunnels and shafts, are unfavorable for ore in great quantity. The bedded deposits are less numerous than the veins, and because of scant development their extent is uncertain, but the evidence available indicates that ore can be reasonably expected from them in greater quantity than from veins.

Crystal Canyon from Lead King Basin to Marble is accessible by highway to a railroad, and along this canyon on the east and south slopes of Sheep Mountain bedded deposits are shown in the Sheep Mountain and Lucky Boy tunnels. At the Lead King, Black Queen, and Black Eagle properties the ore is more closely related in form to bedded deposits than to fissure veins. Each of these occurrences is at a different horizon, although all are in limestones or calcareous beds overlain by shale or shaly members.

A further important consideration is the occurrence of sulphide replacement deposits within the zone of faults and fissures and apparently related to them. As this zone crosses Sheep Mountain (see pl. 1), the Hermosa (?) limestones that it intersects might contain 
some beds favorable for ore. The limestones occur on the lower part of the slope, where outcrops are concealed by talus and heavy growth of vegetation, and as a result they have not been explored.

Detailed geologic work is essential in the immediate vicinity of any prospect before any expenditure of money for development is justified. The geologic map (pl. 1) and the text of this report bring out the fundamental geologic factors and their possible bearing on the rnineral deposits. It is intended here to call attention only to those parts of the area that appear to be the more favorable for further prospecting. In doing this it is necessary to refer to specific deposits, but even here it is very important that those interested should carefully study' in detail the local geology 'before deciding on further development.

\section{MINES AND PROSPECTS}

The deposits are described under two broad geographic divisionsthose in the northern part of the area, which are best accessible through Marble, and those in the southern part of the area, which are more easily reached by way of Crested Butte. These two divisions are subdivided into local areas in order to group together neighboring prospects. Each mine and prospect described is indexed on the geologic map (pl. 1). (See pp. 175-180 for list of claims in numerical and alphabetic order.)

\section{NORTHERN PART OF AREA}

The northern part of the area includes Sheep Mountain, Lead King Basin, Mineral Point, Bear Mountain tunnel, and Treasure Mountain.

\section{SHEEP MOUNTAIN}

Sheep Mountain lies on the north flank of the Treasure Mountain dome. It is a hogback with the Mancos shales on its relatively gentle north slope, Dakota (?) quartzite and Morrison shales forming its top, and Carboniferous formations on the steep south slope that constitutes one wall of the canyon of Crystal River, intersected north of the town of Crystal by the North Fork of the Crystal River.

Black Eagle.-The Black Eagle mine is on the south slope of Sheep Mountain at an altitude of 9,750 feet. It is on a good trail that leaves the road at Lizard Lake. The workings consist of two inclined shafts, both inaccessible, 25 feet apart and said to be 150 feet deep. The shafts follow the base of a limestone bed fully $\eta^{\circ}$ feet thick that strikes N. $60^{\circ} \mathrm{W}$. and dips $31^{\circ} \mathrm{NE}$. The limeston 9 is well marbleized, and some beds show limestone pebbles. About 100 feet down the slope is a second and similar limestone bed, and 
the two are believed to represent the limestone conglomerates so well developed near Crystal Peak and considered the top of the Hermosa (?) formation.

The total ore produced was one shipment ${ }^{74}$ in 1894 of a small carload, which yielded about 165 ounces of silver to the ton. After this date no work was done. According to Mr. Nelson the ore came from the intersection of a steep vein and the base of the limestone. A small vertical fissure striking N. $67^{\circ} \mathrm{W}$. is exposed at the collar of the west shaft, but it passes into the southwest wall of the shaft only 20 feet below the collar, and no fracture is evident at the east shaft. The limestone is not mineralized; therefore the shafts do not follow a vein but probably cut a fissure that has not been recognized at the surface. The dump shows sphalerite, galena, chalcopyrite, and pyrite with a calcite matrix. Native silver is claimed to be present, but I found none.

Black Queen mine.-The Black Queen mine is on the south slope of Sheep Mountain at an altitude of about 10,300 feet and is reached by trail from either Lizard Lake or Crystal. It has produced native silver, but records of total production are lacking. Mr. Nelson states that considerable ore had been mined before he first came to the district in 1890 , and he has a record of a shipment during this period of 360 tons of ore averaging about 150 ounces to the ton, but this is only a small part of the total shipments. Mr. Nelson also has a copy of assays taken from the assay book of the Black Queen and Fargo mines, and according to this record the greatest periods of activity were 1889-90 and 1898-1904. The list records 162 assays that range from 1.0 to $3,291.8$ ounces of silver to the ton and average 139.6 ounces. Two assays of native silver were not included in the average. A mill was built about 1903, but it proved unsuccessful, and from 1905 to 1932 the property was idle. Late in 1932 the mine was unwatered by Joe Juhan, of Denver, and in 1933-34 25 to 30 tons of ore was shipped that is reported to have averaged 30 to 50 ounces of silver to the ton.

Juhan reports a sample from the Black Queen mine that assayed 1 ounce of gold to the ton, but it is claimed that the value of the gold in the ore is equal to one-twentieth of the value of the silver. The assay record referred to above reports gold in 42 assays as follows, in ounces to the ton:

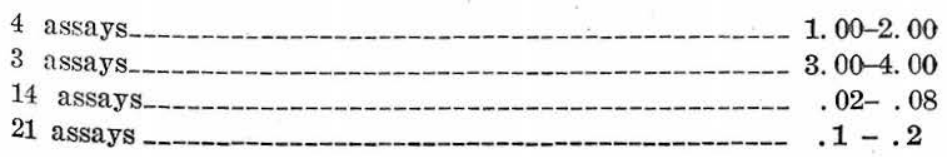

The content of gold in 120 of the 162 listed assays was not reported.

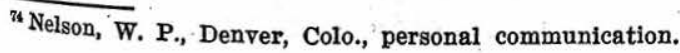


It is evident that the gold is not uniform in its distribution, and the higher assays probably represent hand-picked specimens that cannot be regarded as representative of the ore; high silver does not mean an appreciable gold content.

The mine workings consist of an inclined shaft, which follows the dip of the bedding for about 600 feet, with laterals to the west, as shown in figure 8.

A mill was built at the foot of the slope, 1,500 feet vertically below the mine, and a tram connected the two. Subsequently the tram was removed, and the mill has fallen into decay.

The mineral deposit is in a siliceous limestone 3 to 4 feet thick about 100 to 150 feet stratigraphically above the horizon of the Black Eagle, to the west, and nearly an equal distance below that of the Evening Star, to the northeast. The limestone at the outcrop near

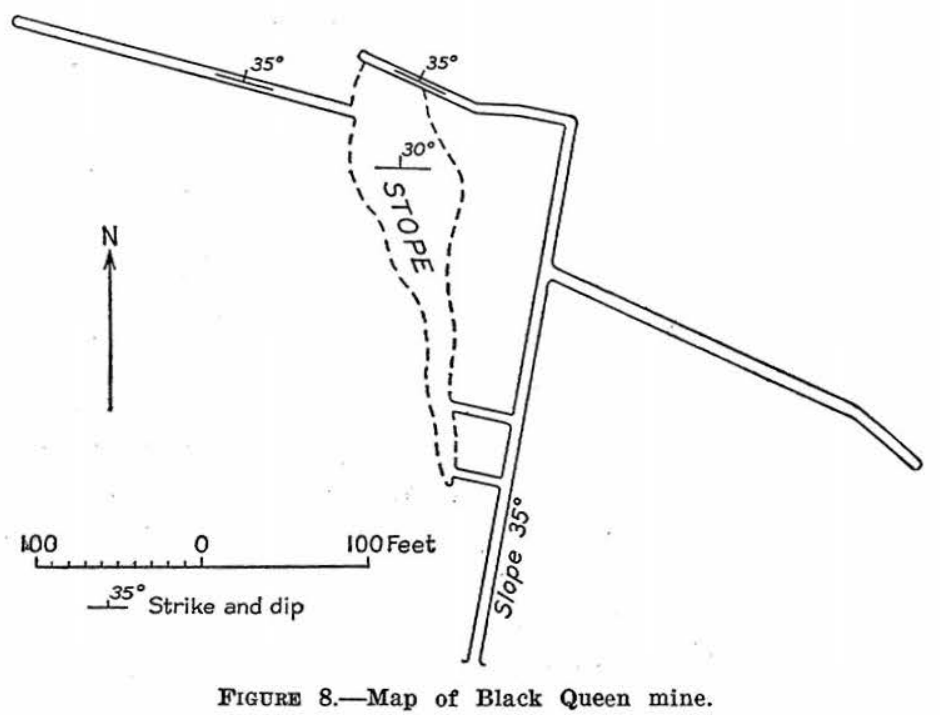

the shaft has been partly replaced by vuggy quartz and shows manganese stain. Some fractures are evident, and one striking N. $7^{\circ} \mathrm{E}$. and dipping $80^{\circ} \mathrm{W}$. is exposed along the trail 60 feet southeast of the shaft. The ore, however, is not veinlike in form, and it is confined to the limy bed and to the overlying altered shale or hornfels, which forms the hanging wall of the stoped area. Stratigraphically higher and lower beds have not been prospected.

The deposit consists of small, scattered segregations of sulphides and native silver. Calcite is the characteristic gangue mineral, although fine-grained white quartz (jasperoid) is common. Some crystalline quartz is also present. Native silver is relatively common, as wire silver in calcite or in aragonite vugs and as platy grains along seams in the black hornfels that forms the hanging wall of 
the mineralized bed. Gray copper is also reported as a source of silver, and it is claimed that the ore carries small amounts of gold. Small amounts of resinous pale-brown sphalerite and some galena are present but are not considered important parts of the ore. Pyrite is abundant throughout the mineralized bed.

Development has been confined to a single stratum, and any structural control that may have influenced the deposition of ore is not clear. The dip of the bed is not uniform, and the steepening or flattening of the bed may have influenced the ore-bearing solutions. Small but numerous fractures and flexures or folds, probably an expression of the northwestward-trending faults known to cross Sheep Mountain, may also have played an important part in localization of the ore. Further development is necessary to determine the significance, if any, of the structural features, and it would be worth while to examine their extension in other limestone strata. Inasmuch as the limestone is mineralized for several hundred feet along the strike and dip, additional work to develop a body of low-grade ore, or to discover new shoots of ore like the one mined, offers some promise.

Catalpa.-The Catalpa mine is about 600 feet north of benchmark 8656, near Twin Bridges, on the Crystal River road, where a small stream of warm water issues from a caved tunnel. A heavy growth of vegetation covers the surface, including the old dump, and conceals the character of the rock and ore that came from the tunnel. No sulphides were found, but the location is of interest because the water is relatively warm, having a temperature of about $68^{\circ} \mathrm{F}$. Another interesting feature is the relatively high calcium-carbonate content of the water as indicated by deposition of lime along the stream. On the slopes below and away from the present course of the water are deposits of calcareous tufa, indicating a former spring. It may be that the tunnel intercepted the channel of such a spring. Evening Star.-The Evening Star is on the south slope of Sheep Mountain, at an altitude of about 10,200 feet, northwest of the Black Queen mine. The workings consist of a tunnel 30 feet long running about N. $80^{\circ}$ W. along the strike of the formation. About 10 feet in from the portal is a winze, inaccessible because of water, which apparently follows down the dip of a bed. Shipment of ore from this prospect has not been reported.

The beds are grits with a few impure limestones of the lower part of the Maroon formation. They strike about west and dip $35^{\circ}-40^{\circ} \mathrm{N}$. Mineralization occurred along a bed of limestone, forming an irregular body of sulphides ranging in thickness from a few inches to 12 inches. Massive dark-brown sphalerite, some galena, chalcopyrite, and much pyrite are exposed in the tunnel. The gangue consists of quartz, calcite, and some fluorite. All the sulphides show crushing and are veined by calcite and by quartz usually associated with pyrite. 
Gold Pan vein.-The Gold Pan vein is about 100 feet south of the Marble-Crystal road 11/2 miles east of Marble, and is opened by a shaft 30 or 40 feet deep. There have been no shipments of ore from this prospect.

The vein occurs in the upper part of the Dakota (?) quartzite along a fault. It strikes N. $56^{\circ} \mathrm{W}$. and dips $75^{\circ} \mathrm{NE}$. The hanging wall moved down with respect to the footwall, horizontally displacing beds about 25 feet, as shown in figure 9 . This vein of massive quartz 2 to 8 feet wide is an excellent illustration of the massive quartz veins that commonly occur in the Dakota (?) quartzite. The vein does not continue far into the Mancos shale above or the Morrison shale below. The fault at the Gold Pan continues some distance into the Mancos formation, at least as far as the limestone
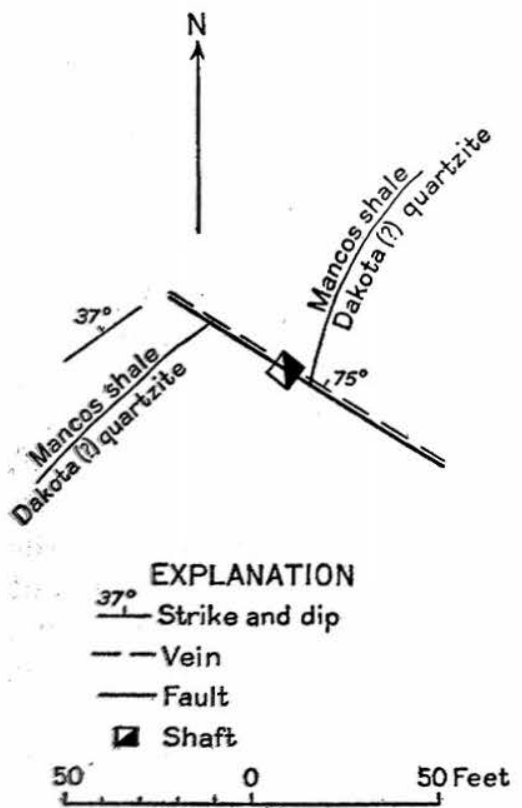

Frgure 9.-Gold Pan vein and fault in Dakota (?) quartzite. member, and where exposed ramifying quartz stringers mark its course. The well-defined vein of quartz does not extend beyond the top of the Dakota (?) quartzite. In the opposite direction the fault cannot be traced far, and the quartz is not continuous far beyond Lost Trail Creek, where the vein joins a fracture that strikes N. $88^{\circ} \mathrm{W}$. and dips $70^{\circ} \mathrm{S}$. This fracture and several others both parallel and at right angles to the Gold Pan vein can be seen in the Dakota (?) quartzite and Morrison formation, which form dip slopes on the northwest side of Hat Mountain. Vein quartz, both as massive filling of fissures and as well-formed crystals projecting into open ,cavities along joints, is common along these fractures. Sparse grains of sphalerite, chalcopyrite, and pyrite are present, but as a rule the veins are barren.

In the vicinity of the shaft the Gold Pan vein is 6 to 10 feet wide and consists chiefly of quartz with small amounts of sphalerite, galena, chalcopyrite, and a little gray copper (tetrahedrite). Both gold and silver are claimed from the specimens that show tetrahedrite, but as no shipments of ore have been made the value is not. known. The sulphides are confined to a relatively narrow band in the otherwise barren quartz vein, and they are not continuous along the strike of the vein. According to reports they were found in the 
upper part of the shaft but not at the bottom. At the bottom of the shaft a drift on the vein to the northwest is again supposed to have found sulphides, which suggests that the body pitches to the northwest, possibly along the Dakota(?)-Mancos contact in the hanging wall of the fault. The same contact in the footwall is not exposed, but it might also have had an influence on the deposition of sulphides. If so this would double the possibilities of the prospect, which though obviously small is favorably located and might therefore be capable of a.small production at a profit. The intersection of this fault and the limestone of Niobrara age may also be mineralized. It is covered with soil, which supports a heavy growth of aspen trees and other vegetation, but the cover is relatively shallow and could be penetrated at a relatively low cost by trenching or with pits.

Inez tunnel.-The Inez tunnel is just west of Crystal, on the west side of the stream. It is readily accessible from the Crystal highway. Production of hand-picked ore is claimed, but the amount is probably small. There are over 1,500 feet of workings on the tunnel level and one stope (fig. 10). The stope, which was not accessible, was opened along the second vein and extends up to the surface. No work is known to have been done below the level of the tunnel.

The country rock consists of feldspathic quartzite and hornfels of the Hermosa (?) formation. The first vein encountered (see fig. 10 ) is chiefly quartz, is only a few inches wide, and illustrates very well the general character of the veins along joints that dip to the west, or in the opposite direction to the faults and large veins, and contain few or no sulphides. The second vein is more complicated, The rocks are much fractured, and vein calcite is plentiful in irregular stringers and masses over a width of 5 to 15 feet. The fractured zone with calcite is again exposed in the short connection between the two almost parallel drifts that extend to the northwest. The western drift follows a stratum that is mineralized but not enough to make ore. This bed loses its identity to the southeast, as it approaches the fractured zone, and a narrow fissure continues, as shown on the map. The veins in the eastern drift are small and unimportant.

The last $300^{\circ}$ feet of the tunnel follows the bedding. On the east side of the fractured zone of abundant calcite the beds strike more nearly north than they do on the west side. As a change of strike commonly occurs on opposite sides of a fault the inference here is that a fault is represented by the fractured zone. The intersection of this zone and a favorable horizon would warrant prospecting if all the rocks in the tunnel were not of the highly siliceous kind that are unfavorable to sulphide mineralization. More promise would seem to be offered by crosscutting from the longer northwest drift to prove the presence or absence of the fractured zone than by extending the tunnel or its present drifts. If a fault is found, the 


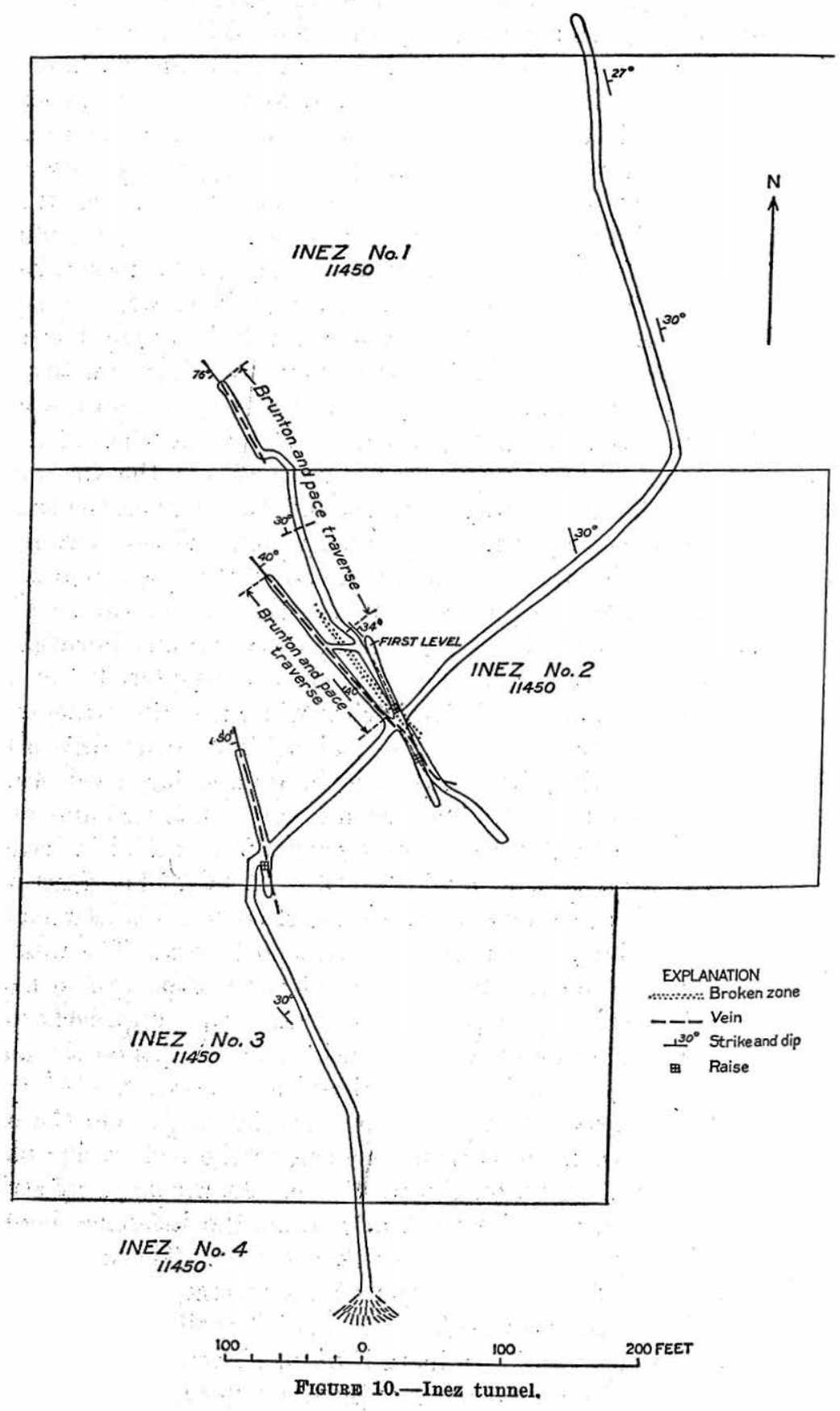


character and amount of mineralization would have to be the guide to further exploration.

Lizard Lake.-A few hundred feet east of Lizard Lake native gold was found by McWilliams \& Brinkmeyer, of Marble. A few sacks of ore were shipped, but the yield is not known. The developments consist of a pit 6 to 8 feet deep on the vein and two crosscut tunnels. The first crosscut tunnel is 75 feet below the outcrop of the vein and about 90 feet long. The second tunnel, 395 feet long, is 700 feet to the south and about 200. feet lower, near the Crystal River. Both tunnels are new since 1930, and neither has intersected the vein. The lower tunnel has been abandoned, but the upper one was being continued when the prospect was last visited, in the summer of 1933.

The gold occurs in a vein in Maroon grits similar to the other numerous veins in the district. The vein strikes N. $25^{\circ} \mathrm{W}$., is vertical, and has a width of about 2 feet. As exposed in the pit the vein consists of two or three stringers of vuggy quartz 2 to 4 inches wide in which the gold occurs probably as a surface concentration. Pyrite is present in the more solid quartz, but only limonite is associated with the gold. The fissure of the vein itself is not strong, and the quartz stringers could not be traced far. As small fractures consistently show a lack of continuity in beds that change as much in character as the Maroon grits, this particular vein is not encouraging. In addition the oxidized part of the vein, to which the native gold and relatively high grade ore are likely to be confined, will certainly be limited in depth by the water table some distance above the level of Lizard Lake. The gold content of the unoxidized parts of the vein cannot be given with certainty; it is probably not more than 0.01 to 0.03 ounce to the ton, the tenor eommon in the numerous similar veins in the area.

Lucky Boy.-The Lucky Boy prospect is half a mile west of Crystal on the north side of a valley at an altitude of 9,200 feet and is marked by a conspicuous light-colored dump. During 1906 or 1907 ten to twelve cars of zinc ore shipped by W. Porter Nelson ${ }^{75}$ yielded 35 to 42 percent of zinc. The shipper was not paid for the other metals, which he said consisted of 2 percent of copper, $21 / 2$ percent of lead, and 5 to 6 ounces of silver to the ton. The developments consist of an upper tunnel 75 feet long and a second tunnel about 20 feet lower, 100 feet long. An incline connects the two.

Both tunnels and incline are along the same stratum in the upper part of a 75-foot limestone bed interbedded with shale and sandstone. The bed strikes N. $75^{\circ} \mathrm{W}$., dips $31^{\circ} \mathrm{NE}$., and is overlain by a limy shale 25 feet thick. Above the limy shale are grits typical

\footnotetext{
To Personal communication.

$131028-37-9$
} 
of the Maroon formation. Only thin, lenticular, impure beds are found above this horizon, which is therefore considered the top of the Hermosa (?) formation (Pennsylvanian).

In the upper tunnel 4 feet of the limestone is brecciated. Numerous veinlets of dark-brown sphalerite and much pyrite are found in this fractured stratum both parallel to the bedding and across it. On the surface the brecciated bed is exposed for fully. 200 feet west of the tunnel, but it shows no sulphides. The easterly continuation is not exposed. Pyrite is relatively abundant along this zone in both the upper and the lower tunnel, but sphalerite, except locally; is present only in smaller amounts. Although sphalerite is the chief economic sulphide, small segregations of chalcopyrite as well as galena are present. Calcite is conspicuous with the galena, which commonly lines cavities in massive sphalerite. Scalenohedrons of calcite grow on both sphalerite and galena.

In the gully just south of the lower tunnel is a vein of massive quartz 18 to 24 inches wide in hornfels. The vein strikes N. $80^{\circ} \mathrm{W}$, dips steeply to the north, and may represent a fault, although displacement could not be determined. It may be that this vein is $\imath$ continuation of that noted in the Lucky Boy. In places the limestone has been silicified, and as quartz is also present with the sulphides a relation with the quartz vein is suggested. The vein where exposed is barren; but its intersection with the horizon of the Lucky Boy to the west would seem to justify consideration for prospecting.

The Lucky Boy vein, from which the shipments referred to above were made, has an average width of 2.8 feet. According to Mr. Nelson, an average assay of nine channel samples taken at intervals across this vein showed 7.9 percent of copper, 4.5 percent of lead, 24.0 percent of zinc, and 12.3 ounces of silver to the ton.

The location with respect to transportation facilities is favorable, and the chances for developing a paying ore body are therefore correspondingly better than those of many of the prospects in more inaccessible places. The extent of the mineralization both along the strike and down the dip in the vicinity of the tunnels should be determined.

Milwaukee-Undine group.-The Milwaukee-Undine group lies in the Dakota (?) quartzite along the top of Sheep Mountain, where there are several faults. (See pl. 1.) Along their strikes in both directions the faults are concealed by talus and vegetation, and horizon markers are generally absent. In addition to the faults, fissures without displacement are present. Both types of fractures have veins in places along their courses. Quartz veins are common in the Dakota (?) quartzite and show the same features found elsewhere in the area, and although accessible with difficulty, nearly all have been prospected; but all efforts seem to have been unsuccessful. 
The veins show, in addition to quartz, much pyrite, some fluorite, and small amounts of sphalerite, chalcopyrite, and galena. The size and sulphide content of the veins are no greater than in many other places in the area, and their location is obviously more unfavorable. They therefore offer little or no encouragement for further prospecting.

Pioneer (Warrior) tunnel.-The Pioneer (Warrior) tunnel is on Lost Trail Creek on the west end of the north slope of Sheep Mountain. The tunnel exposes a strong quartz vein 1 to 6 feet wide along a fault in the Dakota (?) quartzite. The plan of the fault and the tunnel are shown in figure 11. Although the rocks are highly fractured and much quartz is present, there are very few sulphides otherthan pyrite. The prospect is typical of the quartz veins that occur in quartzite.

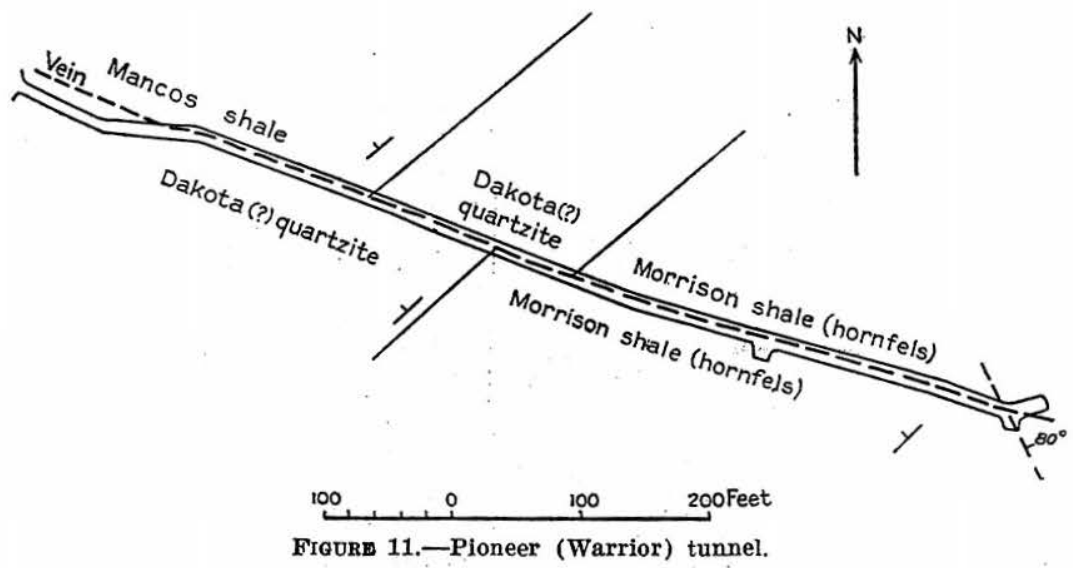

Sheep Mountain tunnel.-The Sheep Mountain tunnel is just west of Crystal, on the north side of the highway. Its purpose was to intersect "all" the veins on Sheep Mountain. Unfortunately, however, the tunnel is confined to a few beds (see fig. 12), and no crosscutting veins of any consequence were intersected. The tunnel followed slightly mineralized beds in country rock of quartzite and hornfels of the lower part of the Maroon formation. In the longer drift a fairly persistent bed of black shaly hornfels averaging 2 feet in thickness was believed by some to be the same bed that contains the ore in the Black Queen mine. Lithologically the beds are similar; both contain pyrite, small amounts of sphalerite, galena, and calcite veinlets. However, other similar beds are also present. It is therefore not safe to correlate any two of them if they cannot be traced continuously, a condition very difficult to fulfill on the slope of Sheep Mountain. 
The south drift also followed a mineralized bed that showed an abundance of pyrite in a matrix of calcite and quartz and that con-

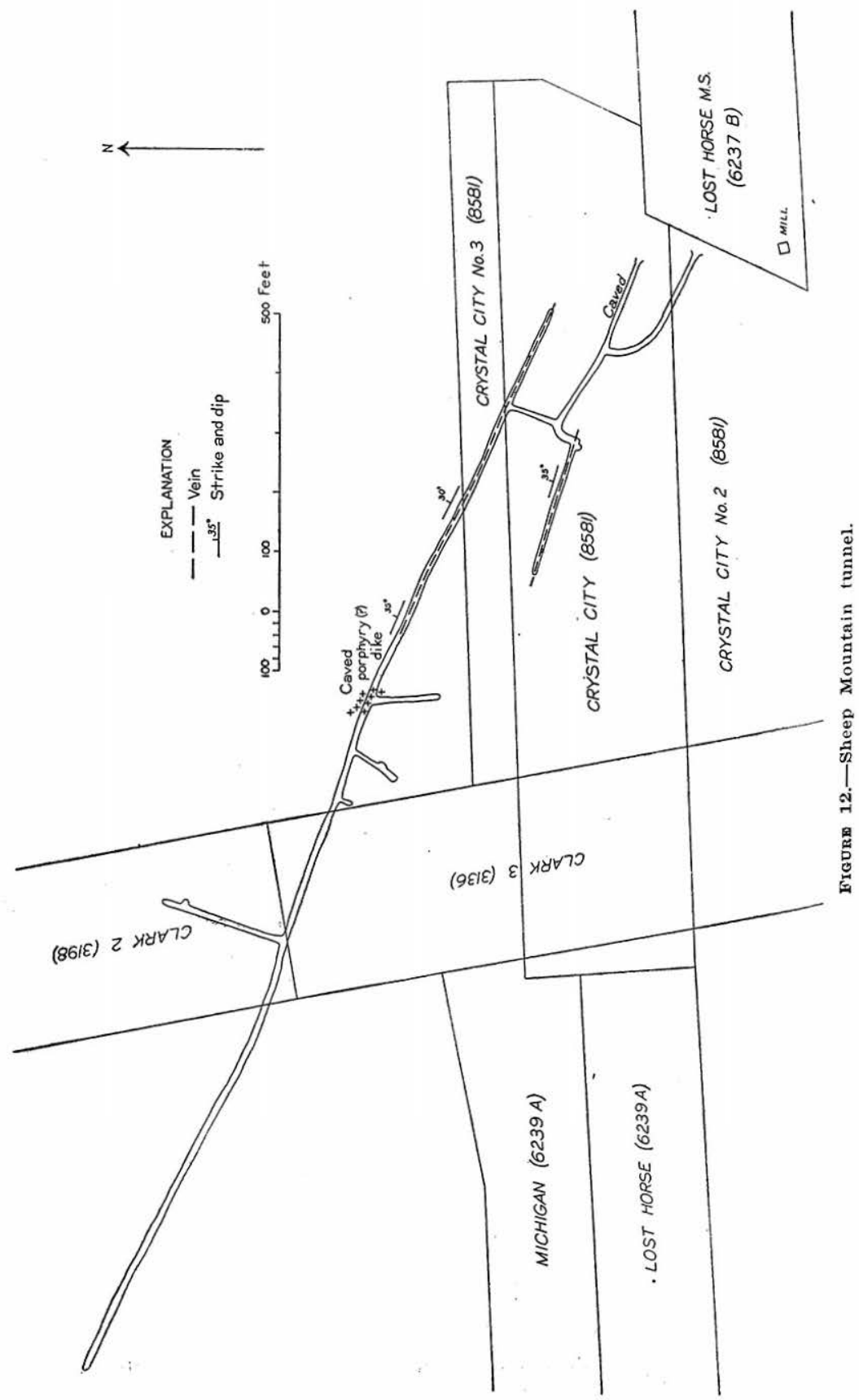

tained sphalerite, chalcopyrite, and galena in small amounts. In several places along the drift the mineralized bed was stoped for 3 to 
4 feet above the level of the drift, and these stopes are supposed to be the source of some of the ore treated in the old mill mentioned below.

A mill was constructed on the south side of the Crystal River opposite the tunnel portal, and some ore was treated but without suecess. According to reports some of the ore milled came from surrounding prospects. Whatever its source, the grade was too low for the inefficient methods of gravity separation employed. As a fair tonnage is represented, however, some effort is justified to determine the possibility of treating the ore with modern methods.

Tennessee of the Black Queen group.-The Tennessee of the Black Queen prospect is not connected with the Black Queen mine except by name. It is just north and about 200 feet vertically above benchmark 8656, near Twin Bridges, on the Crystal River road. Pieces of sphalerite, galena, and chalcopyrite lie scattered on the slope from the road up to the prospect. In $1929^{78} 5.19$ tons of ore from the dump was shipped to the United States Smelting \& Refining Co., Salt Lake City, and yielded assays showing 1.57 percent of copper, 8.25 percent of lead, 14.9 percent of zinc, 12.7 percent of sulphur, 5.0 percent of iron, and 11.5 ounces of silver to the ton.

The amount of development could not be determined, because all openings were caved. Nothing could be learned about the deposit beyond the fact that the sulphides common in the area were present.

\section{LEAD KING BASIN}

The Lead King Basin is a wide area along the valley of the North Fork of the Crystal River where it crosses soft Mancos shales 2 miles north of Crystal. The old road used for hauling ore from this locality is still passable, and it would cost relatively little to make the basin easily accessible to trucks. Several relatively prominent veins have been prospected in this locality, and among them is the vein of the Lead King mine, which is the largest in the entire area. All veins of any size that could be recognized are shown on the geologic map (pl. 1). The formations here dip northward. The outcrops of some of the veins are stratigraphically above the limestone of Niobrara age, which they must intersect a short distance below the surface. As the ore of the Lead King mine is related to this limestone it is surprising that the points of intersection of the limestone by the veins referred to above have not been more fully explored. A few shafts and tunnels, all caved, are located along some of the veins above the limestone. The depth to which these prospects extended is, of course, not known, but the size of each dump appears too small to represent an opening down to the lower part of the limestone, which is the horizon most favorable for ore, according to relations shown in the Lead King mine.

\footnotetext{
${ }^{70}$ Nelson, W. P., personal communication.
} 
Lead King mine.-The deposit of the Lead King mine was not discovered until about 1902 , or fully 25 years after ore was first recognized in the area. Authentic records credit the mine with a total production, chiefly in lead, of nearly $\$ 250,000 .{ }^{77}$ This is by far a larger production not only than that of any other mine in the area but also than that of any other mine in the district.

The composition of the ore is best shown by smelter returns, which, according to settlement sheets of 46 carloads of ore of the early period of production, averaged 12.39 percent of copper, 19.87 percent of lead, 17.25 percent of iron, and 29.15 ounces of silver to the ton.

The smelters do not always give credit for zinc if the ore has been selected for lead, and lead-silver is often lost if the ore is selected for zinc. For this reason older smelter returns do not accurately represent the composition of the ore. Iron was regarded as beneficial in smelting. During 1912 and 1913, 530 tons of ore was shipped by Walter Brace under lease, and this is more representative of the composition of the ore than the earlier shipments. The smelter returns averaged as follows:

Smelter returns of shipments from Lead King mine, 1912-13

\begin{tabular}{|c|c|c|c|c|c|}
\hline Ore & Tons & $\begin{array}{l}\text { Silver } \\
\text { (ounces } \\
\text { per ton) }\end{array}$ & $\underset{\text { (percent) }}{\text { Lead }}$ & $\begin{array}{c}\text { Copper } \\
\text { (percent) }\end{array}$ & $\underset{\text { (percent) }}{\operatorname{Zinc}}$ \\
\hline $\begin{array}{l}\text { Lesd-silver } \\
\text { Zinc } \\
\text { Chalcopyrite-1 }\end{array}$ & $\begin{array}{r}70.44 \\
410.41 \\
49.52\end{array}$ & 58.6 & $\begin{array}{r}62.8 \\
1.3 \\
3.8\end{array}$ & 11.0 & $\begin{array}{l}1.1 \\
46.8 \\
18.1\end{array}$ \\
\hline
\end{tabular}

Attempts to mill low-grade ore by gravity methods of mineral separation have not been successful, but flotation has not been tried. Below is a mill test of material taken from the dump.

Wilfley table test of material from dump of Lead King mine [Made for the Crystal River Mining \& Milling Co., Denver, Colo., Mar. 20, 1915, by the American Zinc Ore Separating Co.]

\begin{tabular}{|c|c|c|c|c|c|c|c|c|}
\hline \multirow[t]{2}{*}{$\ldots$} & \multicolumn{2}{|c|}{ Weight } & \multirow{2}{*}{$\begin{array}{l}\text { Silver } \\
\text { (ounces } \\
\text { per ton) }\end{array}$} & \multirow{2}{*}{$\begin{array}{c}\text { Copper } \\
\text { (per-- } \\
\text { cent) }\end{array}$} & \multirow{2}{*}{$\begin{array}{l}\text { Lead } \\
\text { (per- } \\
\text { cent) }\end{array}$} & \multirow{2}{*}{$\begin{array}{l}\text { Zinc } \\
\text { (per- } \\
\text { cent) }\end{array}$} & \multirow{2}{*}{$\begin{array}{l}\text { Iron } \\
\text { (per- } \\
\text { cent) }\end{array}$} & \multirow{2}{*}{$\begin{array}{l}\text { Insol- } \\
\text { uble } \\
\text { (per- } \\
\text { cent) }\end{array}$} \\
\hline & Pounds & $\begin{array}{l}\text { Per- } \\
\text { cent }\end{array}$ & & & & & & \\
\hline $\begin{array}{l}\text { Original } \\
\text { Wilfiey concentrates............ }\end{array}$ & $\begin{array}{r}6,070 \\
960\end{array}$ & $\begin{array}{r}100.00 \\
15.81\end{array}$ & \multirow{9}{*}{$\begin{array}{r}0.90 \\
2.22 \\
138.99 \\
.48 \\
112.92 \\
1.06 \\
135.51 \\
.88 \\
18.05 \\
1.36 \\
15.98\end{array}$} & \multirow{9}{*}{$\begin{array}{r}0.80 \\
.30 \\
5.93 \\
. .30 \\
9.03 \\
1.80 \\
67.85 \\
.40 \\
15.54 \\
1.20 \\
\quad 5.94\end{array}$} & \multirow{9}{*}{$\begin{array}{r}11.60 \\
42.20 \\
66.13 \\
3.80 \\
7.93 \\
6.90 \\
18.80 \\
2.90 \\
6.48 \\
11.20 \\
3.83\end{array}$} & \multirow{9}{*}{$\begin{array}{r}16.80 \\
6.30 \\
5.93 \\
46.70 \\
67.33 \\
11.40 \\
20.45 \\
5.50 \\
8.46 \\
12.80 \\
3.01\end{array}$} & \multirow{9}{*}{$\begin{array}{r}13.10 \\
19.40 \\
23.41 \\
5.10 \\
9.43 \\
26.80 \\
61.68 \\
2.70 \\
5.33 \\
8.10 \\
2.44\end{array}$} & \multirow{9}{*}{$\begin{array}{r}17.90 \\
1.34 \\
1.10 \\
5.04 \\
6.82 \\
7.47 \\
12.60 \\
46.60 \\
72.91 \\
31.60 \\
6.97\end{array}$} \\
\hline Saving.......... & & & & & & & & \\
\hline Static zinc. & 1,470 & 24.22 & & & & & & \\
\hline Saving ............ & & & & & & & & \\
\hline Static iron. & 1,830 & 30.15 & & & & & & \\
\hline $\begin{array}{l}\text { Saving } \\
\text { wilfley tails }\end{array}$ & & & & & & & & \\
\hline $\begin{array}{l}\text { Wilfley tails } \\
\text { Loss }\end{array}$ & 1,570 & 25.86 & & & & & & \\
\hline Wilfley slimes......... & 240 & 3.96 & & & & & & \\
\hline Loss. & & & & & & & & \\
\hline
\end{tabular}

1 Percent.

Ore crushed to 20 mesh. Sized in three sizes, $20-40,40-80$, and -80 mesh. The original percentage of lime was 5.60 , and of static zinc 3.60 .

${ }^{\pi}$ Henderson, C. W., Bur. Mines, Denver, Colo., personal communication. 
About 1917 some dump ore was milled, and 138.5 tons of concentrates was produced, but they were not shipped until 1929. The average smelter returns, from the United States Smelting \& Refining Co., Salt Lake City, showed 4.15 percent of copper, 5.85 percent of lead, 32.82 percent of zinc, and 7.60 ounces of silver to the ton.

The developments consist of a main tunnel about 600 feet long (see fig. 13, A), several raises and stopes, and two vertical winzes reported to be over 100 feet deep. Both winzes were filled with water and were inaccessible. The stopes, which are in ore, continue to the surface. - Drifts connecting these stopes at higher levels are caved, and only 20 to 30 feet of the stoped area above the main tunnel could be examined.

Almost due east about 500 feet from the main tunnel and only a little above the level of the stream is a tunnel over 1,000 feet long, shown in figure 13, B. The purpose of this tunnel seems to have been to explore ground near the Lead King deposit, but it is too far from the favorable places to be effective. The veins intersected by this tunnel are weak and not commercially important.

Mancos shale, including the limestone of Niobrara age, forms the country rock; it strikes $\mathrm{N}$. $70^{\circ}-75^{\circ} \mathrm{W}$. and dips about $30^{\circ} \mathrm{NE}$. The limestone crops out in conspicuous and nearly continuous exposures from a point near the stream to a point well above and west of the mine. The shale is calcareous, grading into the limestone, which itself contains interbedded shale, and underground the two are difficult to distinguish. In the main tunnel the limestone is recognized in the crosscut near the end of the tunnel, but the position of its base could not be satisfactorily placed. It appears, however, that the stopes are just below or in the lower part of the limestone bed.

The sulphides that constitute the ore of the Lead King mine are typical of the area as a whole, but the gangue differs in that it consists entirely of calcite and fluorite; quartz and pyrite, which are so abundant elsewhere, are relatively scanty here. The ore minerals and gangue occur in irregular ramifying veinlets distributed in a zone essentially parallel to the bedding. Individual veinlets of massive sphalerite 1 to 3 inches wide are in the walls of the stope, but apparently their total volume was too small to constitute ore.

These veinlets show a fairly definite sequence of filling of fractures. Chalcopyrite, sphalerite, and fluorite either together or separately form the walls; calcite and galena are very characteristic along the more central parts. Calcite scalenohedrons lining vugs are common. The fluorite ranges from rose pink to green, and some is colorless.

Breccia occurs along the vein in places, particularly in that part of the floor of the stope accessible immediately above the tunnel. 
The breccia consists of fragments of rock and a little sulphide ce. mented by fine-grained white calcite; it ranges in width from less

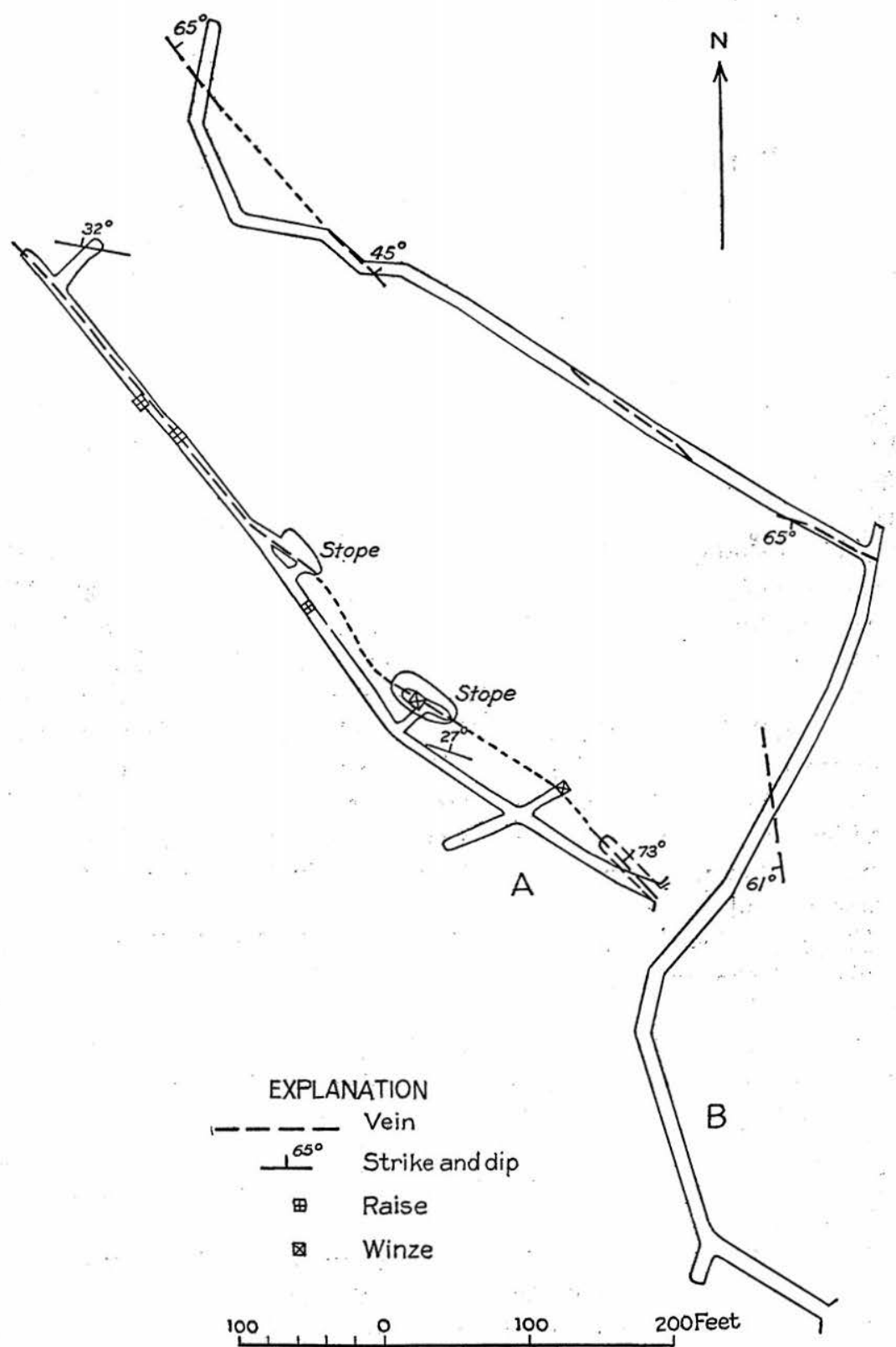

FIGURE 13.-A, Tunnel of Lead King mine; B, Lower barren prospect tunnel, Lead King mine.

than an inch to 12 inches. Northwest of the second stope in from the portal (see fig. 13, A) the breccia gives way to a calcite vein, 
6 to 12 inches wide; this vein was followed by the tunnel to the face, where some breccia is again present. At the portal of the tunnel is a calcite vein 12 to 18 inches wide with several inches of chalcopyrite along each wall. This vein may be continuous with the breccia-filled fissure. However, a short drift just above the tunnel shows this vein to pinch to a width of a few inches in less than 30 feet.

The ore formed along the intersection of fissures and the lower part of the limestone member. The fracture intersected the bedding at a small angle, and its strike changes on passing from shale to limestone. As nearly as could be determined the first stope pitched about $50^{\circ} \mathrm{NW}$. and the second stope about $65^{\circ} \mathrm{NW}$. The two winzes, being vertical, do not approach the zone along the line of the pitch of the stopes. Old maps show the presence of some ore in both winzes, whereas from other sources barren massive pyrite is reported. If any ore is present its amount is probably small; otherwise it would have been mined. All reports agree that sulphides occur in these winzes, and this occurrence, insofar as it indicates a continuation of mineralization downward, argues for rather than against the presence of ore below the tunnel level. In view of the fact that no change in geologic conditions is evident at the tunnel level, below which there has been only scant development, further prospecting is justified. The stopes are at or in the lower part of the limestone member, and the top of this member, somewhere beyond the face of the tunnel, is also a favorable place for prospecting.

\section{MINERAL POINT}

Mineral Point as seen from Crystal is the top of a steep cliff, between the North and South Forks of the Crystal River. It is, however, the end of a ridge that forms the divide between these streams.

The lower part of the bold cliffs near Mineral Point is Maroon grit, and the upper part consists of Morrison shale and Dakota (?) quartzite. Mancos shale forms the crest of the ridge a short distance back of Mineral Point and the edge of the cliff. The quartzite along the top of the cliffs, as is common elsewhere in the area, is traversed by several fissure veins. The veins trend northwestward, and correlation of some of them on opposite sides of the ridge is suggested by their approximate alinement, but they cannot be traced through the overlying Mancos shale. Prospects on fissure veins are the Daisy, Belle of Titusville, and Burt.

Daisy.-The Daisy, north of Mineral Point, is a caved and inaccessible tunnel. The portal, at an altitude of a little more than 10,000 feet, is in Dakota (?) quartzite only a few feet below the Mancos 
shale, and the tunnel runs along a fissure vein that trends N. $45^{\circ} \mathrm{W}$. and dips $60^{\circ}-70^{\circ} \mathrm{SW}$. The fissure is without apparent displacement. Much of the dump is Mancos shale, and specimens showing sphalerite, chalcopyrite, galena, and some fluorite are present. Whether development was continued along the vein or along a contact is not known.

Belle of Titusville.-The Belle of Titusville is about a mile east of Crystal on the south slope of Mineral Point, at an altitude of about 10,000 feet and not far east of the Burt. It is reached by a short

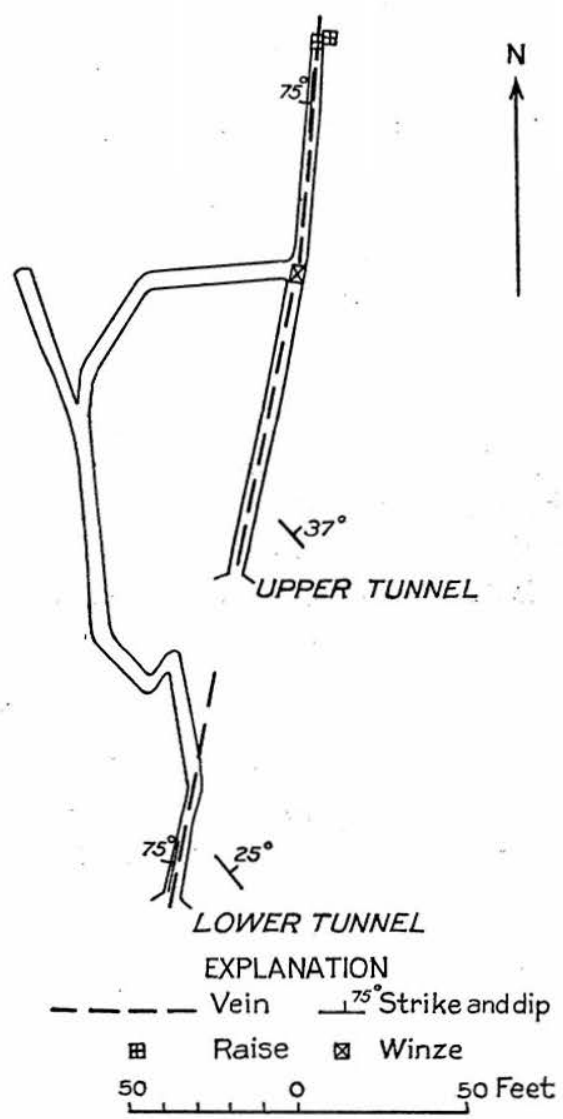

Figurd 14.-Belle of Titusville tunnels. steep trail from the old road along the Crystal River. The developments consist of two tunnels (see fig, 14), one about 50 feet vertically, above the other along a narrow fissure vein. The winze at the end of the upper tunnel connects with the lower tunnel. A small production of silver is claimed. The ore was run down a chute to the road below and hauled by wagon to a 10-ton mill located near the stream and operated by water power. The amount of silver. produced is, not known, but it cannot have been large.

The fissure vein of the Belle of Titusville is in Jurassic rocks, which strike N. $35^{\circ}-40^{\circ} \mathrm{W}$. and $\operatorname{dip} 25^{\circ}-37^{\circ} \mathrm{NE}$. The upper tunnel follows the vein. The lower tunnel after drifting on the vein for about 30 feet turns west and is off the vein for fully 200 feet before it swings back to intersect it at a winze that extends down from the upper tunnel. Wherever exposed the vein is less than 2 inches wide and consists largely of galena in calcite gangue. The ore is said to be of high tenor in silver, and according to reports this vein, though small, was continuous and constituted the source of the ore mined and milled. The developments along the vein do not give any evidence that it can be expected to be wider to the north, and with ordinary metal prices the vein is too small to be promising.

The vein strikes east of north and is not in accord with the trend of the faults and stronger veins in the area. In this respect the Belle 
of Titusville vein is not entirely unique, but it represents the only vein with a northeast strike that has been developed to any extent.

Burt.-The Burt prospect is about a mile east of Crystal on the south slope of Mineral Point, at an altitude of about 10,250 feet, not far west of the Belle of Titusville. The same trail from the road along the Crystal River that leads to the Belle of Titusville continues on up to the Burt. Tunnels aggregating fully 1,000 feet in length have been made, but no ore was produced. Three tunnels

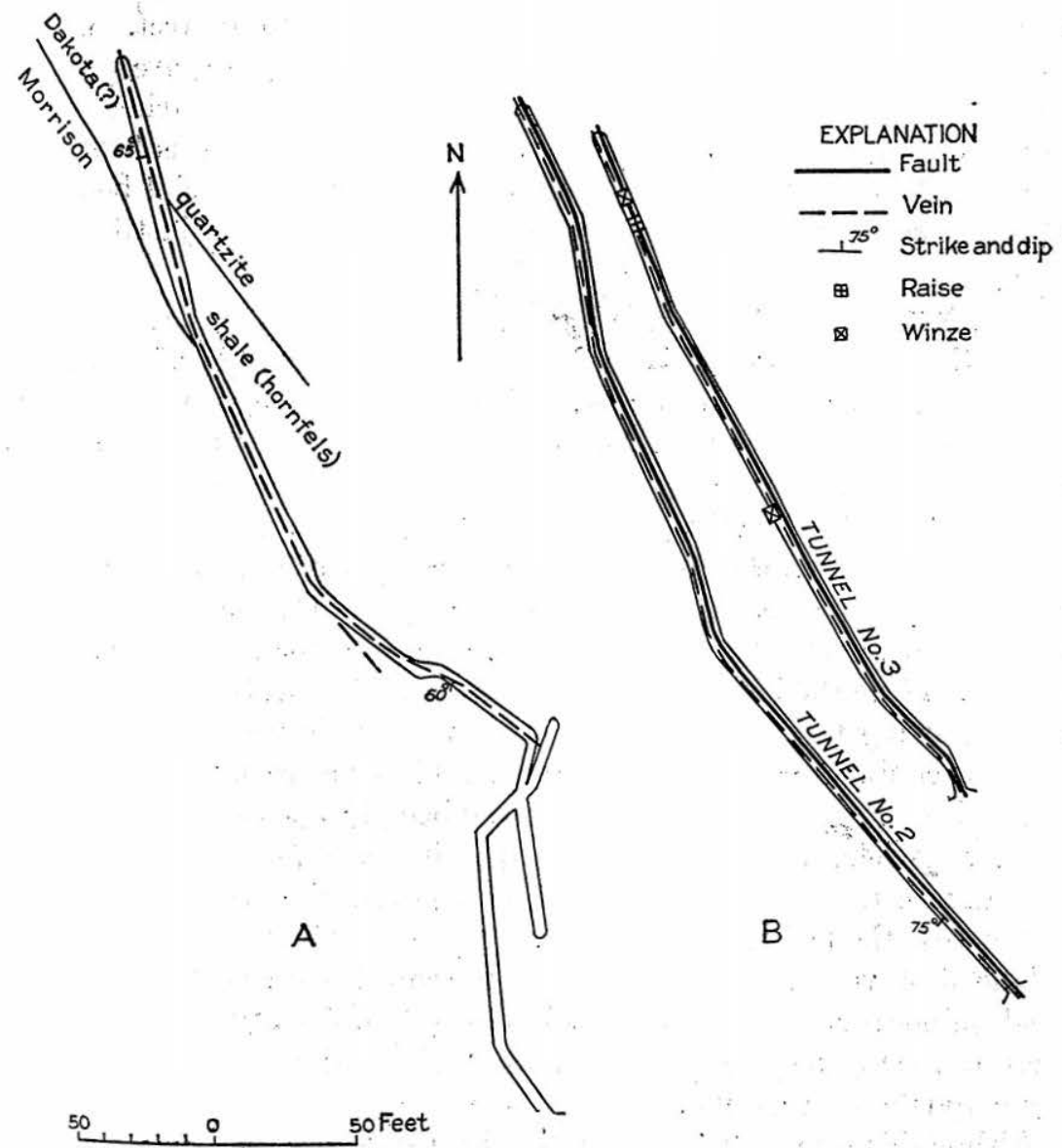

Figure 15.-Burt tunnels. A, Lowest; B, second and third.

were accessible and are shown in plan in figure 15. A fourth tunnel about 25 feet above tunnel 3 and on the same vein was inaccessible. The tunnels follow two nearly parallel fault fissures in the Jurassic rocks and Dakota (?) quartzite. The fissures, which are only 30 to 40 feet apart, strike N. $30^{\circ}-35^{\circ}$ W. and dip $60^{\circ}-75^{\circ}$ SW. On each fault the hanging wall moved down and displaced the beds 10 to 20 feet vertically. The lowest tunnel follows the eastern fault, and the 
three higher tunnels are on the western fault. The veins consist largely of quartz and average less than 12 inches in width, although locally they are 3 feet wide. The usual sulphides and fluorite are present. In tunnel 2 coarse vuggy quartz occurs along the fault, and sphalerite, chalcopyrite, and galena line the quartz vugs. Along the wall of this tunnel an area 6 feet across showed only sulphides, but this face represented a longitudinal section of a stringer less than an inch across. Between tunnels 2 and 3, where the vein is well exposed at the surface, the relations are shown better than underground. Here the quartzite is shattered through a width of 4 to 10 feet, and the vuggy quartz partly fills the fractures. The sulphides are confined $w$ the vugs along the main zone of movement or fracturing, which is less than 2 feet wide. In view of the fact that the veins have been moderately well explored without encountering commercial bodies of ore, further expenditure for development does not seem justified.

\section{BEAR MOUNTAIN TUNNEL}

On the north slope of Bear Mountain at an altitude of 9,050 feet is a tunnel about 450 feet long, shown in plan in figure 16 . It was planned to intersect a vein that carried much silver at the outcrops, several hundred feet above the tunnel level. The tunnel was not continued to its objective.

The Pennsylvanian Hermosa (?) formation crossed by the tunnel consists largely of calcareous shale, sandstone, and some limestone in contact with granite of the Treasure Mountain stock. As determined on the surface the beds strike northwest and dip northeast, but in the tunnel, owing to the broken rock, this attitude is not evident. Likewise the contact between sedimentary and igneous rock in the tunnel is indefinite. It appears to cut across the beds in places and to parallel them elsewhere along northerly dips that are as low as $25^{\circ}$. On the surface the trend of the contacts suggests that the igneous rock cuts across the beds at a steep dip.

The first vein in the tunnel is a narrow fissure that shows only weak mineralization. The second vein is 1 to 3 feet wide and shows quartz, pyrite, some fluorite, and a few small spots of sphalerite, chalcopyrite, and galena.

Although unimportant commercially, this tunnel is interesting because it shows the local trend of veins, which is not evident from surface exposures. In addition the tunnel proves that mineralization was later than the intrusion of the Treasure Mountain stock.

\section{TREASURE MOUNTAIN}

The Skyline and Lead Bullet prospects are referred to Treasure Mountain for lack of any other reference point. As a whole the mountain lies outside the zone of faulting and shows very little sulphide 
mineralization. The two prospects are of interest because they occur where other evidence of mineralization is lacking. The Skyline is of further interest because it represents the only occurrence in the entire

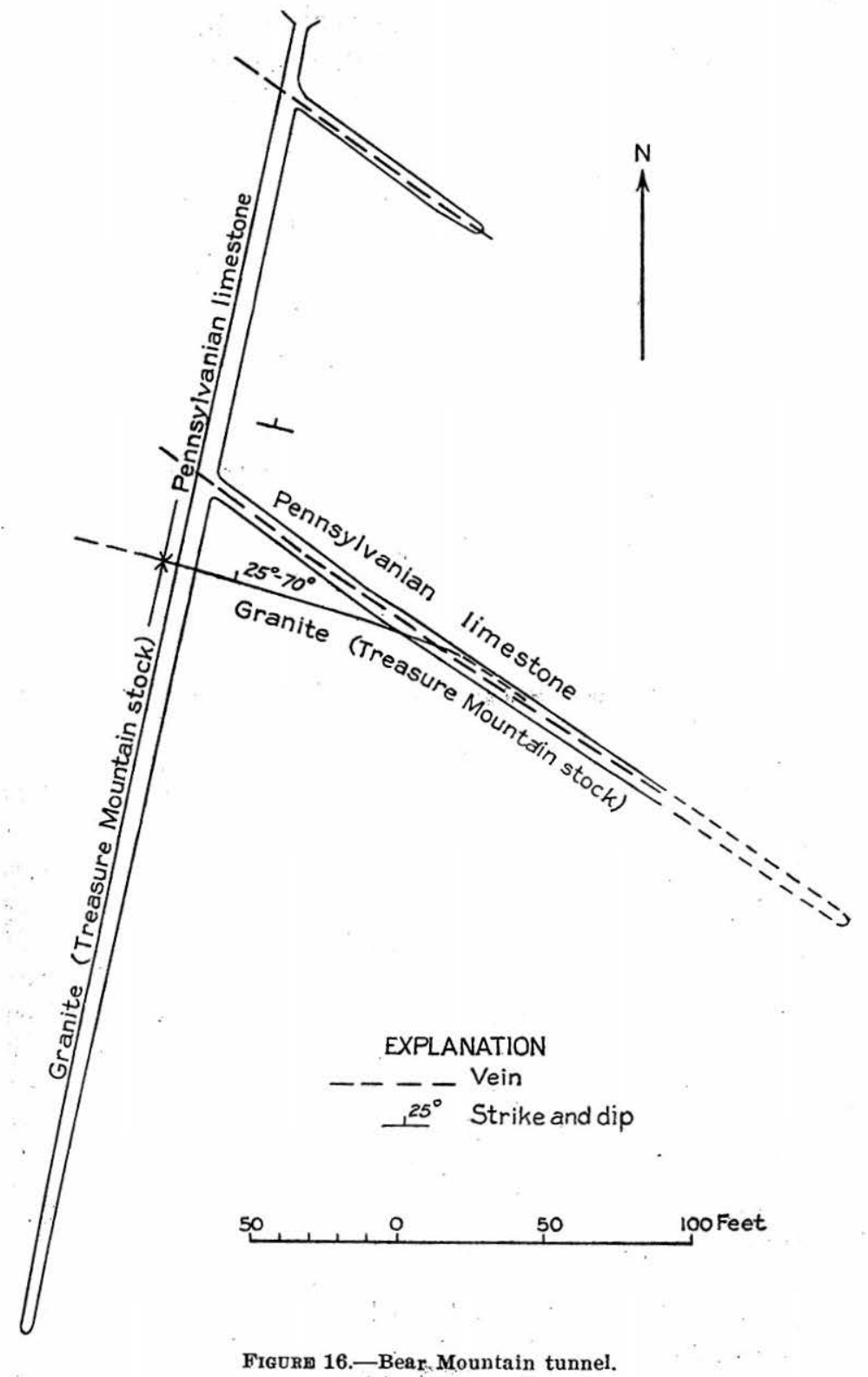

district of sulphide mineralization in the Mississippian (Leadville) limestone. 
Lead Bullet.-The Lead Bullet prospect is at an altitude of 12,050 feet on the north slope of Treasure Mountain, a few hundred feet below the crest of the divide between Treasure and Whitehouse Mountains. It can be reached from either Yule Creek or the Crystal River over precipitous trails that climb 3,000 feet in less than 2 miles. At this altitude snow gathers as early as September and remains until June or July. After the snow has melted, which is usually in late summer, water can be obtained only from a small stream several hundred feet below.

In addition to the workings at the location given, there is a lower group of prospects formerly known as the Jack Wacker claims, about 3,000 feet to the southwest and a few hundred feet lower, on the opposite side of the divide. The upper workings consist of a tunnel, which was inaccessible, and the lower workings include numerous pits, open cuts, and a caved tunnel. A small tonnage is reported to have been shipped from the open pits and cuts in the early days. No shipments have been made from either workings in recent years.

From the distribution of the workings it seems that mineralization was confined to the Parting member or other formations near it, at the base of the Devonian. Spongy and vuggy masses of quartz, with quartz crystals lining the openings, replace one of the calcareous beds of the Parting member where it crosses the divide and afford further evidence of mineralization at this horizon. The tunnel on the north slope or upper workings is in the upper part of the Manitou (Ordovician) dolomite at the portal and is run southwest. Quartz masses on the dump resemble those found on the divide in the Parting member, but whether the tunnel intersected this member is not certain. The lower workings are in the Parting member, and the pits, open cuts, and tunnels have been confined to it. Veins are not evident, and it is probable that mineralization followed the stratification; accordingly this deposit is classed as a bedded deposit.

Sulphides were found only on the dump of the upper workings and consisted of galena and pyrite with a gangue of fluorite and quartz. A high silver content is claimed for the ore, but an assay of selected galena gave only 11 ounces of silver to the ton. This relatively small amount of silver is in accord with the usual finding in the area-namely, that galena does not necessarily make highly argentiferous ore. At the lower workings the rocks are iron-stained, and all the sulphides that may have been present are leached out. The presence of quartz and fluorite gangue indicates that the min. eralization at the lower and upper places was essentially the same.

A high silver content, if present, probably occurs only in the oxidized parts of the mineralized bed and represents an enrichment of the metal. The proof of high silver, its associations, and the 
form of the metal are important in determining the possibilities of the prospect.

Skyline.-The Skyline mine is three-quarters of a mile northwest of the Lead Bullet and 400 feet lower, at an altitude of 11,650 feet; it can be reached by the same trails.

A few tons of almost pure coarsely crystalline galena ore is reported to have been shipped. Silver has not been quantitatively important, although a small amount is present. The development consists of an irregular opening 5 to 20 feet across that follows down the mineralized zone for a distance of about 40 feet.

Mineralization occurred in the lower part of the Mississippian (Leadville) limestone along a zone or band of dolomite marble. Several similar layers of dolomite, except that they lack sulphides, are interbedded with the white calcite marble in the lower part of the Mississippian. There is evidence of some mineralization at the same horizon to the southwest, on the opposite side of the divide. These are the only places in the area in which evidence of sulphide mineralization was recognized in the Mississippian (Leadville) limestone.

The ore, consisting of massive coarsely crystalline galena, occurs in irregular masses almost devoid of gangue and other sulphides. The form of the ore body is not clear, but evidence of a vein is lacking: and the body seems to be a massive replacement deposit. The sedimentary formations dip to the southwest, and the stope, of irregular form, pitches in the same direction but at a steeper angle. As a result the stope, which is about 40 feet long, ends at a horizon 15 or 20 feet stratigraphically below the zone in which it starts and in which mineralization appears to have been strongest. The extent, if any, of mineralization down the dip has therefore not been determined, but it is clearly limited along the strike of the bed, which is well exposed in the cliff.

Yule Creek.-The somewhat isolated Yule Creek deposit is about a mile southeast of the quarry of the Yule Colorado Marble Co. No' ore is known to have been shipped from this prospect. It has been developed by a shaft, which was not accessible, and a tunnel 230 feet long in the relative positions shown in figure 17.

The ore occurs in the lower part, or Parting member, of the Devonian Chaffee formation and consists of dark-brown to black sphalerite with some pyrite and a small amount of calcite gangue. Galena and chalcopyrite were not observed. The tunnel, apparently planned to intersect a zone exposed in the shaft, crosscuts the beds and then follows a stratum for almost 50 feet to the point where ore is first encountered. The first indication of mineralization is a gouge 1 to 2 inches thick along a bedding surface. The gouge continues for several feet until it abruptly gives way to a 6 -inch layer of massive 
sphalerite, which increases in thickness to 12 inches within the next 9 feet along the strike. The 12 -inch vein continues 18 feet and is then cut off by a vertical fault that trends N: $78^{\circ} \mathrm{E}$. From the fault to the face of the tunnel the rocks are barren. The fault caused very little fracturing of the rock and was not evident on the surface. The amount and direction of movement on it could not be determined from the scant development.

The form of the deposit as exposed in the tunnel is clearly tabular parallel to the bedding. The bed along which the sphalerite was deposited projects to the surface 10 or 15 feet east of the shaft, and it should have been found at a depth of about 15 or 20 feet in the shaft, which is claimed to be 40 feet deep and bottomed in mineralized rock. The relations suggest the possibility that the bed encountered in the shaft may not be at the same horizon as the one in the tunnel.

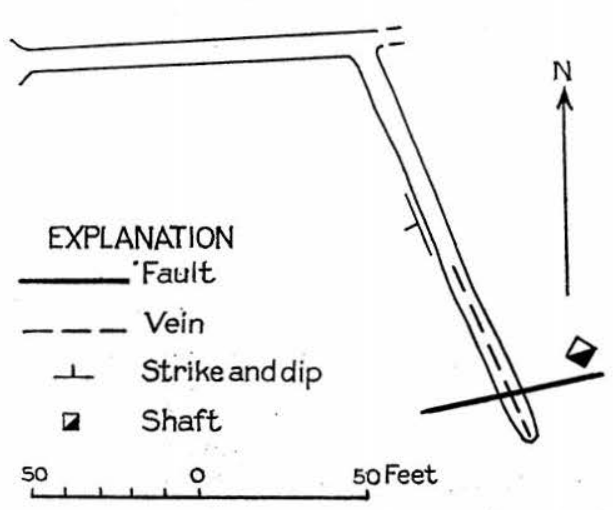

FIGURE 17.-Zinc prospect on Yule Creek about a mile southeast of the Yule Colorado marble quarry.

of the shaft should also be considered.

This deposit is of interest because it is virtually isolated and well outside of the main mineralized belt. Some pyrite and a very little galena were noted on the northwest end of the knoll a little over 1,000 feet to the northeast. Apart from this the closest mineral deposits are the Skyline and Lead Bullet prospects, about 2 miles to the north, both of which are themselves outside the main mineralized zone.

\section{CRYSTAL MOUNTAIN TUNNEL}

The portal of the Crystal Mountain tunnel is southeast of Crystal at an altitude of a little less than 9,500 feet, on the stream that drains Bear Basin. The tunnel was driven in an easterly direction to intersect the downward extension of the veins, including the HarrisFarley group, that crop out on the east slope and on the north end of Crystal Mountain. There is no record that veins of economic 
importance were intersected. The tunnel, which is now inaccessible, is shown in figure 18.

The tunnel is in the Hermosa beds (?), with its portal about 150 feet vertically below the limestone conglomerate that in mapping was considered the top of the formation. Whether or not any

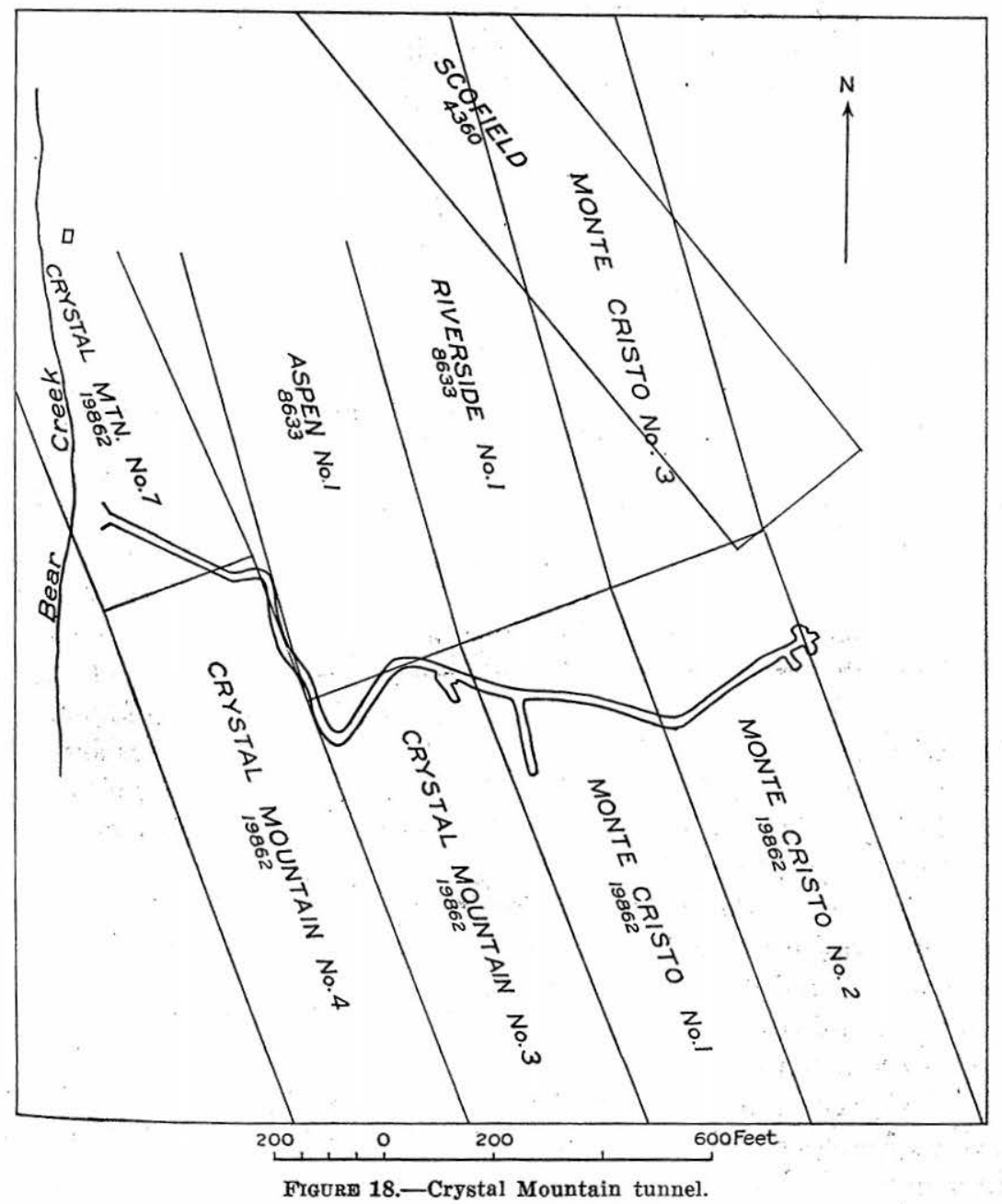

Maroon grits were intersected by the tunnel could not be determined. On the mine map from which figure 18 was taken each short branch from the main tunnel was marked as "drift on vein", and from this it is inferred that mineralization occurred at these places. 


\section{HARRIS-FARLEY AND HIGH TIDE VEIN GROUP}

Several veins crop out on the northeast slope of Crystal Mountain. They trend northwestward, crossing the north end of the mountain above an altitude of 11,000 feet. Some of the veins are visible in the precipitous cliffs from the valley below. A little ore is said to have been shipped from these veins, but no regular production was made. Of the numerous workings on these veins the Harris-Farley tunnel, which is about 600 feet long, and the High Tide shaft and tunnel seem to be the most extensive.

The veins occur along faults and are typical in their character and habit of those common to the area. Their strikes are northwest, and they are vertical or dip steeply northeastward. Several of those shown could not have been recognized except for the presence on Crystal Mountain of the Morrison (Jurassic) formation, which served as a horizon marker and permitted recognition of offsets. It is very unlikely that all the fissures are shown on the geologic map, and, moreover, it is almost certain that fissures extend farther along the strike than is shown. However, their branching character and the known lack of persistence of individual fractures make it unsafe to project them far beyond their outcrops. Some hold to the view that the Harris-Farley vein and the High Tide vein are continuous; although this is possible, it is far from being demonstrated, but there can be no doubt that they are related. Efforts have also been made to trace these veins across the valley of the Crystal River to Sheep Mountain, but without success. It is unlikely that individual fractures are continuous across this interval, but the zone of faults and veins as a whole is continuous, as is shown by the fissure veins that cross the crest of Sheep Mountain.

In the Harris-Farley tunnel the quartz vein is 15 to 30 feet wide; it shows pyrite and a small amount of the economic sulphides. The vein is reported to carry 1 to 2 ounces of silver to the ton and only small amounts of copper, zinc, and lead. At the High Tide the workings were not accessible. Surface outcrops are oxidized and show a relatively large amount of chrysocolla with the amorphous black oxide of copper. On the dumps sphalerite, galena, and chalcopyrite in a gangue of quartz and fluorite are common though not particularly abundant.

\section{SOUTHERN PART OF THE AREA}

\section{NORTH POLE MINE}

The North Pole mine is at an altitude of 12,150 feet in North Pole Basin, between Crystal and Galena Mountains. In spite of its diffcultly accessible location some ore was shipped. The shipments, of which there is a partial record, ${ }^{78}$ included both oxide and sulphide

${ }^{n 8}$ Nelson, W. P., Denver, Colo., private file. 
ores. The oxide ore was treated by the Hoffman Smelting \& Reduction Co., at Marble, in 1898 and 1899. This ore averaged about 12 percent of copper, the only metal mentioned, and yielded the shipper $\$ 4,049.79$ after deduction of the smelting charge of $\$ 7$ a ton. From 1902 to 1906 some sulphide ores were shipped, but although the composition of the ore is given, the amount of ore represented is not indicated. The shipments are listed in detail below, and they are of interest because they represent an ore that is relatively high in copper as compared with other deposits in the area. Furthermore, a good silver content goes with the copper, which is not the rule in most of the other prospects.

Shipments of ore from North Pole mine

\begin{tabular}{|c|c|c|c|c|c|}
\hline Date & Buyer & $\begin{array}{l}\text { Gold } \\
\text { (ounce per } \\
\text { ton) }\end{array}$ & $\begin{array}{c}\text { Silver } \\
\text { (ounces per } \\
\text { ton) }\end{array}$ & $\begin{array}{c}\text { Copper } \\
\text { (percent) }\end{array}$ & Remarks \\
\hline $\begin{array}{l}\text { Dec. 10,1902 } \\
\text { Do } \\
\text { Sept. 10,1903 } \\
\text { Do. } \\
\text { Sept. 19,1905 } \\
\text { Do } \\
\text { Oct. } 12,1905 \\
\text { Dec. } 7.1905 \\
\text { Dec. } 18,1905 \\
\text { Dec. } 24,1905 \\
\text { Dec. } 27,1905 \\
\text { Jan. } 4,1906 \\
\text { Do } \\
\text { Jan. } 8,1906 \\
\text { Do } 1,1906 \\
\text { Jan. } 10,1906 \\
\text { Jan. } 11,1906 \\
\text { Do.....- } \\
\text { Jan. } 10,1906\end{array}$ & 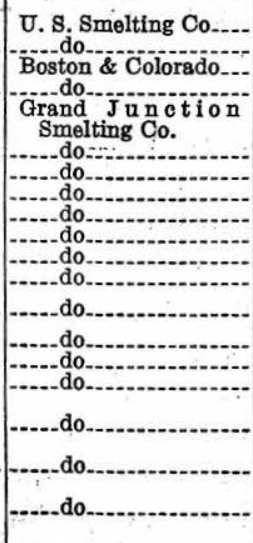 & $\begin{array}{c}0.02 \\
.01 \\
.01 \\
.02 \\
.02 \\
0.015\end{array}$ & $\begin{array}{r}3.36 \\
13.90 \\
13.70 \\
13.70 \\
6.60 \\
7.50 \\
4.96 \\
7.20 \\
6.40 \\
5.35 \\
4.41 \\
5.15 \\
5.65 \\
6.20 \\
5.80 \\
4.34 \\
5.50 \\
4.80 \\
5.43\end{array}$ & $\begin{array}{r}13.50 \\
1.30 \\
14.30 \\
14.30 \\
3.87 \\
4.39 \\
4.66 \\
4.60 \\
5.30 \\
5.60 \\
4.30 \\
5.50 \\
5.75 \\
6.00 \\
5.80 \\
5.30 \\
4.60 \\
5.20 \\
5.35\end{array}$ & 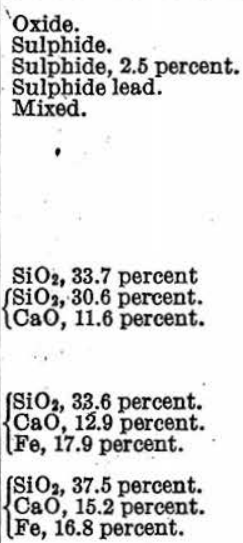 \\
\hline
\end{tabular}

The workings are not extensive. They consist of two upper tunnels; the Shakespeare and the North Pole (see fig. 19), and a lower crosscut tunnel. The Shakespeare tunnel is caved. The lower crosscut tunnel was planned to intersect the ore of the North Pole tunnel at depth. It crosscuts several hundred feet of Hermosa (?) beds but does not reach its objective. Hermosa (?) quartzite, recrystallized limestone, and shale altered to hornfels form the country rock. The beds strike N. $15^{\circ}-20^{\circ} \mathrm{W}$. and $\operatorname{dip} 25^{\circ}-30^{\circ} \mathrm{NE}$. In 20 to 30 feet in the North Pole tunnel (see fig. 19) the strike is N. $10^{\circ}$ E., but this appears to be local, as it is not reflected on the surface where outcrops are good. The change of strike is suggestive of a fault or a sharp local flexure; which would also account for the fracturing.

The mineral deposit seems to have been formed by replacement along a limy bed. The distribution of minerals as observed in the 
North Pole tunnel is shown in figure 19. Descriptions indicate that the plan of the Shakespeare tunnel, to the southwest, approximately parallels that of the North Pole, and it may be along the same stratum at a slightly lower level. The bedding is not evident in the North Pole tunnel where ore is present, but in the short southwest crosscut and just inside of the portal it is well defined and is approximately parallel to the main tunnel. Underground the trend of the banded quartz is north to northwest, and if it continues in this direction the last 30 to 40
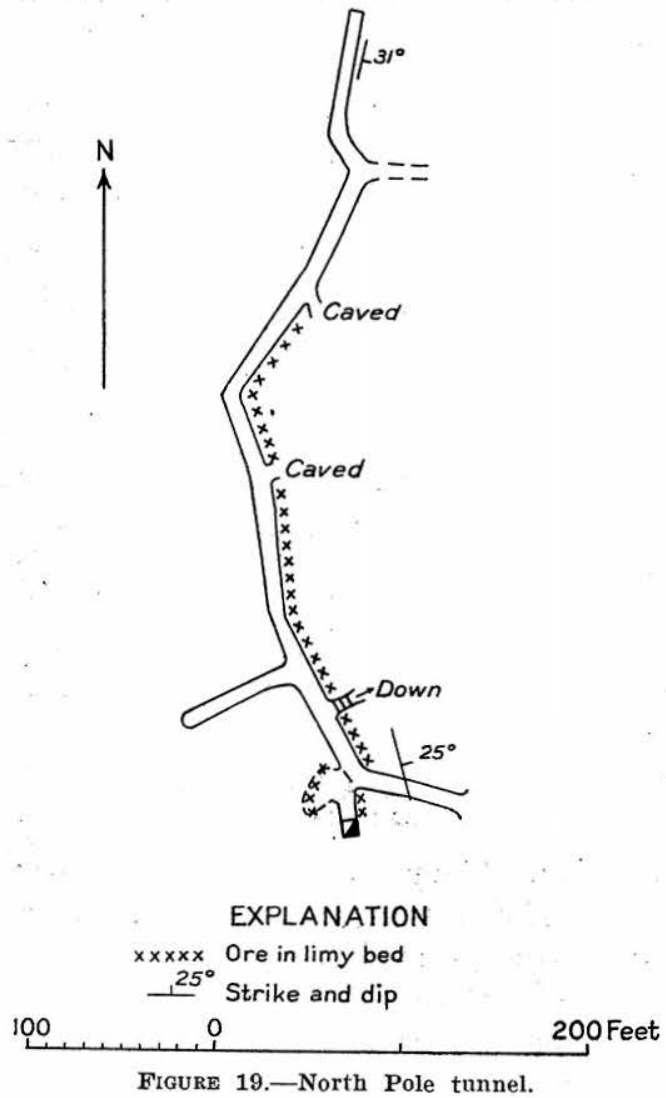
feet of the tunnel is east of the mineralized zone.

The usual sulphides, sphalerite, chalcopyrite, galena, and pyrite, are present. However, the percentage of copper shown by the ore shipped is relatively high as compared with the average throughout the area. In addition to quartz and fluorite, which are common, hedenbergite is a characteristic gangue mineral and is relatively abundant. It is banded with quartz and usually occurs along the top and bottom of the ore as exposed in the tunnel. Brown resinous garnet is also abundant nearby, but whether it constitutes a vein mineral is not certain. Hedenbergite is common with garnet that formed during the period of metamorphism induced by the Treasure Mountain stock of granite. The presence of hedenbergite, a contactmetamorphic mineral, in the North Pole ore that also contains sulphides is interpreted to mean that this deposit shows the transition from the period of metamorphism to the period of vein formation. The relatively high copper content of the ore tends to support this tentative conclusion. 
Galena Mountain forms a ridge between Schofield Park and North Pole Basin. Numerous veins, most of which have been prospected, are to be found on this ridge and southward to Rock Creek. Mexican Cut and the Blue Jay, Rockett, Homestake, and Brooklyn tunnels, described separately, lie in this small area, which represents the south-central part of the mineralized fault zone. Special mention is made of this area as a whole because of the large number of faults that are shown. The detail given on the geologic map (pl. 1) was possible because a separate topographic base on a scale of 1 to 12,000 was available. The area was mapped and described separately in a preliminary report. ${ }^{7 \theta}$ The character of the topography and the presence of good horizon markers made many of the otherwise obscure faults recognizable.

None of the veins have made any regular production of ore, though it is said that small shipments were made from several prospects. The veins are all essentially the same, consisting largely of quartz with much pyrite and small amounts of sphalerite, chalcopyrite, galena, and locally tetrahedrite (gray copper). Fluorite is almost invariably present, and calcite is widely distributed in small amounts. In the low saddle south of Galena Lake barite, not common elsewhere, is abundant. Specularite is common and most abundant in those quartz veins along the larger faults that are more or less continuous. An abundance of specularite, barite, quartz, or pyrite does not indicate the amount of economic sulphides that may be present.

Mexican Cut.-On the east slope of Galena Mountain a mineralized stratum over 1,000 feet in length is exposed in the cliff of a glacial cirque. This locality is generally referred to as Mexican Cut, which is also the name of the patented claim showing the best sulphide outcrop. There is no record of shipment of ore from Mexican Cut, and the developments consist of several shallow cuts. Mineralization occurred along the limestone 40 to 60 feet above the base of the Morrison formation. The strike of the beds is roughly parallel to the trend of the bluff, and the dip is easterly. The limestone has been largely replaced for several hundred feet along the outcrop by metamorphic silicates. Within this zone silicification and deposition of quartz with small amounts of sphalerite and galena and some chalcopyrite occurred. In one cut a deposit of massive sulphide almost 3 feet across and several feet long has been exposed, but its extent has not been determined. The rocks show the usual amount of fracturing, but fissure veins are lacking,

\footnotetext{
${ }^{79}$ Vanderwilt, J. W., Preliminary geologic notes on Galena Mountain, a part of Snowmass Mountain area, Colo.: Colorado Sci. Soc. Proc., vol. 13, no. 1, pp. 5-18, 1932.
} 
and the relations suggest a bedded deposit. The cliff along which the mineralized limestone crops out is approximately parallel to the fault system of the area, and the mineralization could have been related to a fracture now largely removed by erosion. Future prospecting should be directed along the limestone formation, as the hornfels both above and below is not mineralized.

Blue Jay tunnel.-The Blue Jay.tunnel is east of Galena Mountain and a few hundred feet below the mineralized limestone of Mexican Cut. It is a straight drift about 300 feet long on a fissure vein that strikes $\mathrm{N}$. $70^{\circ} \mathrm{W}$. and dips vertically. The vein changes along its strike from a barren knife-edge fracture to quartz averaging less than 2 inches in width with local lenses 24 inches wide. The wider part of the vein is of slight extent along the drift and apparently also vertically, as two raises in the widest part, about 50 feet from the face of the tunnel, were not continued far. These raises were not accessible. Chalcopyrite, much pyrite, and some sphalerite occur in the quartz, which also contains a little specularite. The quantity of ore is too small to be of commercial value, but the vein is of interest because it represents a mineralized fissure with a strike that is $40^{\circ}-50^{\circ}$ farther west of north than the strike of the main fault zone.

Rockett tunnel.-The Rockett tunnel is about 1,500 feet east of Galena Lake on Galéna Mountain, at an altitude of 11,700 feet. This prospect represents mineralization on a branch fissure of a larger fracture, the Whopper fault. At the tunnel portal, near the base of the Dakota (?) quartzite, there is a displacement along the vein of 5 to 10 feet. To the north the fissure cannot be traced across the hornfels of the Morrison (Jurassic) shale. To the south the displacement increases as the larger fault is approached, and it is in line with a fracture that branches from the Whopper fault. Obviously, in considering the possible continuity of a particular fissure vein, it is important to determine its relation not only to rock formations but also to fractures nearby.

The vein is typical of those common in the Dakota (?) quartzite. It is 12 inches to 2 feet wide and consists largely of quartz with much pyrite, a little sphalerite, chalcopyrite, galena, and some fluorite. It has little commercial promise.

Homestake tunnel.-The Homestake tunnel is on the glacial bench that lies above and southwest of Schofield Park. It is almost due north of the Brooklyn tunnel and has been driven south in the Whopper fault. It extends for about 300 feet in the massive quartz vein, which is fully 20 feet wide along the fault. Pyrite is relatively abundant, and sphalerite, chalcopyrite, and galena are present only in small amounts. 
Brooklyn tuinnel.-The Brooklyn tunnel is on the southeast slope of Galena Mountain. It was intended to intersect several veins that crop out higher up the slope, in the Mancos shale immediately above the Dakota (?) quartzite. The plan of the tunnel and fractures encountered are shown in figure 20. No ore was shipped.

The tunnel crosses the Whopper fault and passes from Mancos shale into Dakota (?) quartzite about 150 feet in from the portal. The fault is marked by a vein of calcite 2 feet wide and considerable massive quartz with pyrite, specularite, and small amounts of sphalerite, galena, and chalcopyrite. About 250 or 300 feet in from the portal the tunnel crosses a second fault and passes from the quartzite into hornfels of the Morrison, in which it continues to the face. The fractures in the hornfels are small and, as is characteristic of this rock, show relatively little mineralization. It is somewhat doubtful whether the tunnel reaches its objective. The veins exposed on the surface would have to extend across the entire thick-

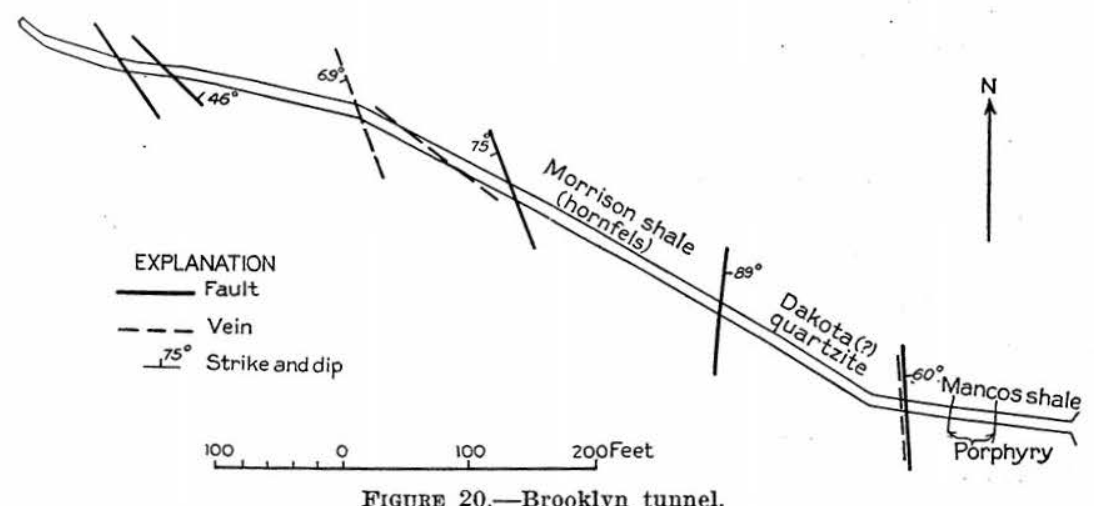

ness of the Dakota (?) quartzite and a considerable thickness of Morrison formation before reaching the tunnel level. Veins of this type may extend some distance in the Dakota (?) quartzite, but they would not ordinarily continue far below the quartzite; generally the veins pinch out on passing into hornfels.

\section{SCHOFIELD PARK}

The canyon of the Crystal River southeast of Crystal is narrow and steep-walled for 5 miles and then widens into an open valley called Schofield Park. The park is less than a mile north of Schofield Pass and is accessible from Crested Butte by car. A town called Schofield, marked in 1933 by a few dilapidated cabins, was located here and served the surrounding territory.

The floor of the valley is Dakota (?) quartzite on the east. and Morrison on the west. Only small amounts of sulphides, chiefly 
pyrite, are present. The veins characterized by these sulphides are chiefly in Dakota (?) quartzite, and iron-stained outcrops are common, but prospecting in the park has not developed any commercial deposits. The veins strike and dip parallel to the trend of the main fault zone.

Whopper lode.-The Whopper lode is on the north side of the Crystal River Canyon almost 3 miles above Crystal and abot: \pm half a mile below Schofield Park. It is at an altitude of 10,300 feet, a few hundred feet vertically above the trail that follows along the stream. The property has been developed by a shallow shaft and two tunnels, one about 20 feet vertically above the other. The upper tunnel is 80 feet and the lower one 60 feet long on the vein. A small stope, which, however, was inaccessible, is at the end of the upper tunnel. Frazer ${ }^{\$ 0}$ examined the prospect in 1881, and at. that time, according to his description, the upper tunnel was 66 feet long and a lower tunnel 37 feet long. A shaft 30 feet deep is also mentioned in his report. Little recent development work has been done, although an effort has been made to sort ore on the dump for shipment. The amount of ore shipped cannot have been large.

Mineralization occurred along a fault with a northwest strike and steep easterly dip which has been traced for more than 4 miles to the southeast and which has been named the Whopper fault, after this deposit. The base of the Dakota (?) quartzite is about 6 feet above the upper tunnel on the east side of the fault and is nearly 50 feet higher on the west side of the fault. The fault continues to the northwest, and a few small pits, each showing some sulphides, are located along its course. The vein was prospected to the south. Owing to poor exposures its continuity is not certain to the northwest beyond the limestone of Niobrara age in the Mancos shale. In the Dakota (?) quartzite the vein is 2 to 4 feet wide, with an average of a little over 2.5 feet. In all probability the vein, if it follows the habit of other veins in quartzite in the area, is less well developed in the Mancos and Morrison shales than it is in the Dakota (?) quartzite.

Sphalerite, galena, chalcopyrite, and tetrahedrite (gray copper) constitute the economic sulphides, and pyrite, quartz, and some fluorite the gangue minerals. The mineralogy of the vein is therefore in keeping with that of the veins at other prospects in the area. About one-third of the vein is estimated to be ore that carries well above the average proportion of economic sulphides

${ }^{80}$ Frazer, Persifor, Jr., The Whopper lode, Gunnison County, Colo.: Am. Inst. Min. Eng. Trans., vol. 9, pp. 249-258, 1881. 
to gangue in most of the veins. Prommel ${ }^{81}$ examined the property and obtained the following assays from channel samples of the vein:

Assays of samples from Whopper lode

\begin{tabular}{|c|c|c|c|c|c|c|}
\hline 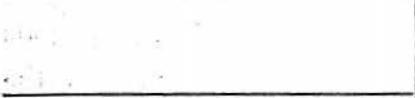 & $\begin{array}{c}\text { Width of } \\
\text { vein } \\
\text { (feet) }\end{array}$ & $\begin{array}{c}\text { Gold } \\
\text { (ounce } \\
\text { per ton) }\end{array}$ & $\begin{array}{l}\text { Silver } \\
\text { (ounces } \\
\text { per ton) }\end{array}$ & $\begin{array}{c}\text { Copper } \\
\text { (percent) }\end{array}$ & $\begin{array}{c}\text { Zinc (per- } \\
\text { cent) }\end{array}$ & $\begin{array}{c}\text { Lead } \\
\text { (percent) }\end{array}$ \\
\hline 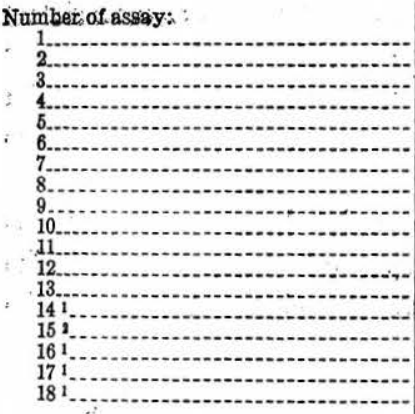 & \begin{tabular}{r|}
2.7 \\
2.5 \\
3.2 \\
2.4 \\
2.0 \\
3.5 \\
2.1 \\
4.3 \\
3.0 \\
3.7 \\
2.6 \\
3.4 \\
2.3 \\
3.5 \\
-1.5 \\
\end{tabular} & 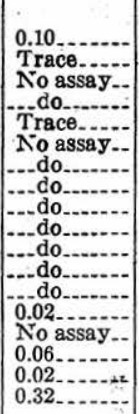 & $\begin{array}{r}39.30 \\
1.70 \\
2.70 \\
.44 \\
2.40 \\
4.20 \\
2.40 \\
6.30 \\
18.00 \\
3.70 \\
2.50 \\
3.20 \\
7.30 \\
6.50 \\
1.20 \\
9.85 \\
10.20 \\
59.30\end{array}$ & $\begin{array}{r}0.73 \\
1.35 \\
1.45 \\
.42 \\
1.56 \\
1.35 \\
.42 \\
2.29 \\
.52 \\
.94 \\
1.25 \\
1.14 \\
1.14 \\
4.26 \\
.42 \\
2.60 \\
1.77 \\
.73\end{array}$ & $\begin{array}{r}7.45 \\
\text { No assay } \\
12.97 \\
2.82 \\
\text { No assay } \\
11.60 \\
4.50 \\
4.05 \\
6.20 \\
8.80 \\
4.62 \\
.67 \\
3.38 \\
9.80 \\
1.25 \\
24.80 \\
6.20 \\
7.45\end{array}$ & $\begin{array}{r}3.47 \\
\text { No assay } \\
7.84 \\
.45 \\
\text { No assay } \\
4.70 \\
7.50 \\
4.70 \\
2.35 \\
2.35 \\
2.02 \\
7.62 \\
6.16 \\
27.99 \\
1.46 \\
15.90 \\
42.78 \\
2.02\end{array}$ \\
\hline
\end{tabular}

1 Sorted ore.

2 Ore'from veiń in a digging about 250 feet south by east of the tunnels but presumably the same vein.

These assays of the. Whopper lode probably give the relative proportions of the important metals in ore that may be expected in other quartz veins in the area, but of course the volume of the ore is not indicated. Sorting, as shown by samples 14, 16, 17, and 18, would obviously be practicable. Samples 16, 17, and 18 are of particular interest as they represent selective sorting of zinc (16), lead (17), and silver (18). Separation of zinc from lead was only moderately successful, but the selection of lead and silver was quite satisfactory. Silver was selected on the basis of amount of tetrahedrite observed, and the result obtained proved that here at least galena was not very argentiferous.

With a favorable price of metals the Whopper lode may be an exception among the quartz veins in the area, which as a group offer little promise of containing commercial ore bodies. The assays given represent the vein as opened horizontally and vertically for about 100 feet. The geologic conditions are simple, so that further prospecting or development can be planned efficiently and at a minimum cost. Intersections of the Whopper fault with known favorable beds, such as the limestone of Niobrara age in the Mancos shale and the limestone about 60 feet above the base of the Morrison formation, are worthy of consideration. Such intersections are as a rule not well exposed and consequently have not been explored. Shallow pits or trenches are generally sufficient to determine whether

\footnotetext{
Prommel, H. W. C. (consulting geologist and mining engineer, Denver, Colo.), private report, October 1929.
} 
mineralization has occurred and, if so, whether it appears to be of economic importance.

John Baroni tunnel.-The John Baroni tunnel is on the east side of Schofield Park in the Mancos shale. On the dump is a few tons of high-grade lead-zinc ore. The tunnel is about 300 feet long, as shown in figure 21. It intersects a small part of the Mancos shale below the limestone of Niobrara age. A dike of the type of the Lincolh porphyry is also intersected and appears to have been an important objective for prospecting, but the porphyry does not show mineralization. Sulphides are confined to veins, the largest of which is well defined, is 2 to 12 inches wide, and is crossed obliquely by the tunnel. (See fig. 21.)

The sulphides locally are massive and consist largely of resinous sphalerite, galena, pyrite, and small amounts of chalcopyrite. The gangue comprises quartz, calcite, and a little fluorite. A part of the
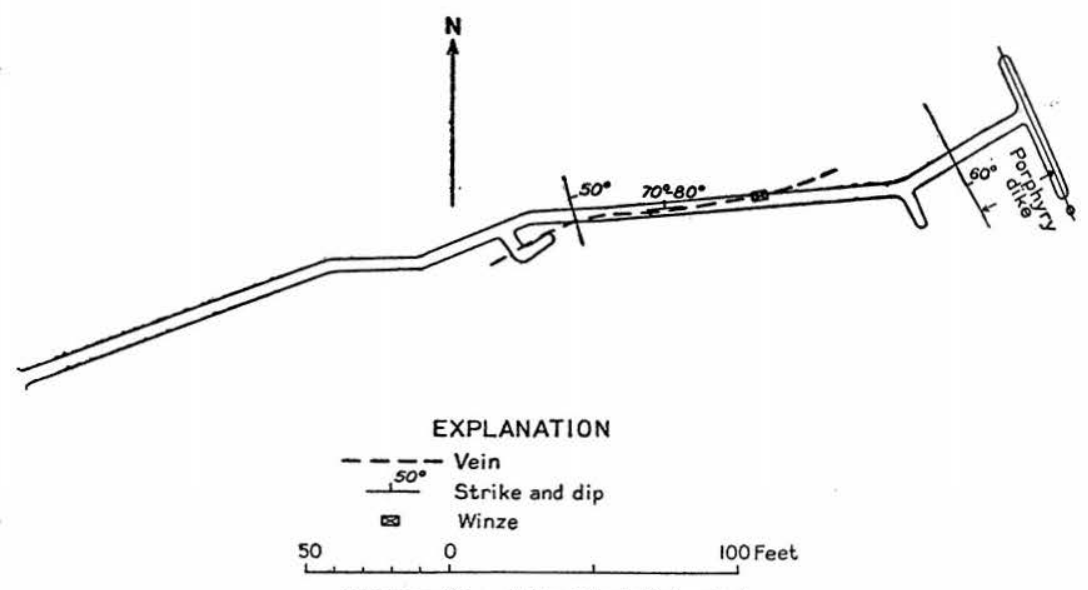

Figure 21.-John Baroni tunnel.

vein contains high-grade zinc-lead ore, but because of its narrowness the prospect is not very encouraging. However, the possible extension of the vein into the limestone member of the Mancos is worthy of consideration, especially as it would cost relatively little to prospect this zone.

Hercules-Ajax mine.-The Hercules-Ajax-mine is on the east tributary of Rock Creek about 1,000 feet east of Schofield Park proper. Some ore is said to have been treated in the mill formerly located at the lower end of Schofield Park. The workings (see fig. 22) include on the south side of the stream a short tunnel along the vein and on the opposite side of the stream a shaft 90 feet deep with a drift 40 feet long along the vein 60 feet below the surface. In 1929 and 1930 a new tunnel was driven on the north side of the stream to intersect the vein, but the extension proved the vein to be only a few inches wide and to consist largely of pyrite. 
The mineralization followed a well-defined fissure vein that strikes N. $55^{\circ} \mathrm{E}$. and dips $70^{\circ} \mathrm{NE}$. The fissure is a fault that is paralleled by two other faults a few hundred feet upstream, east of the mine.

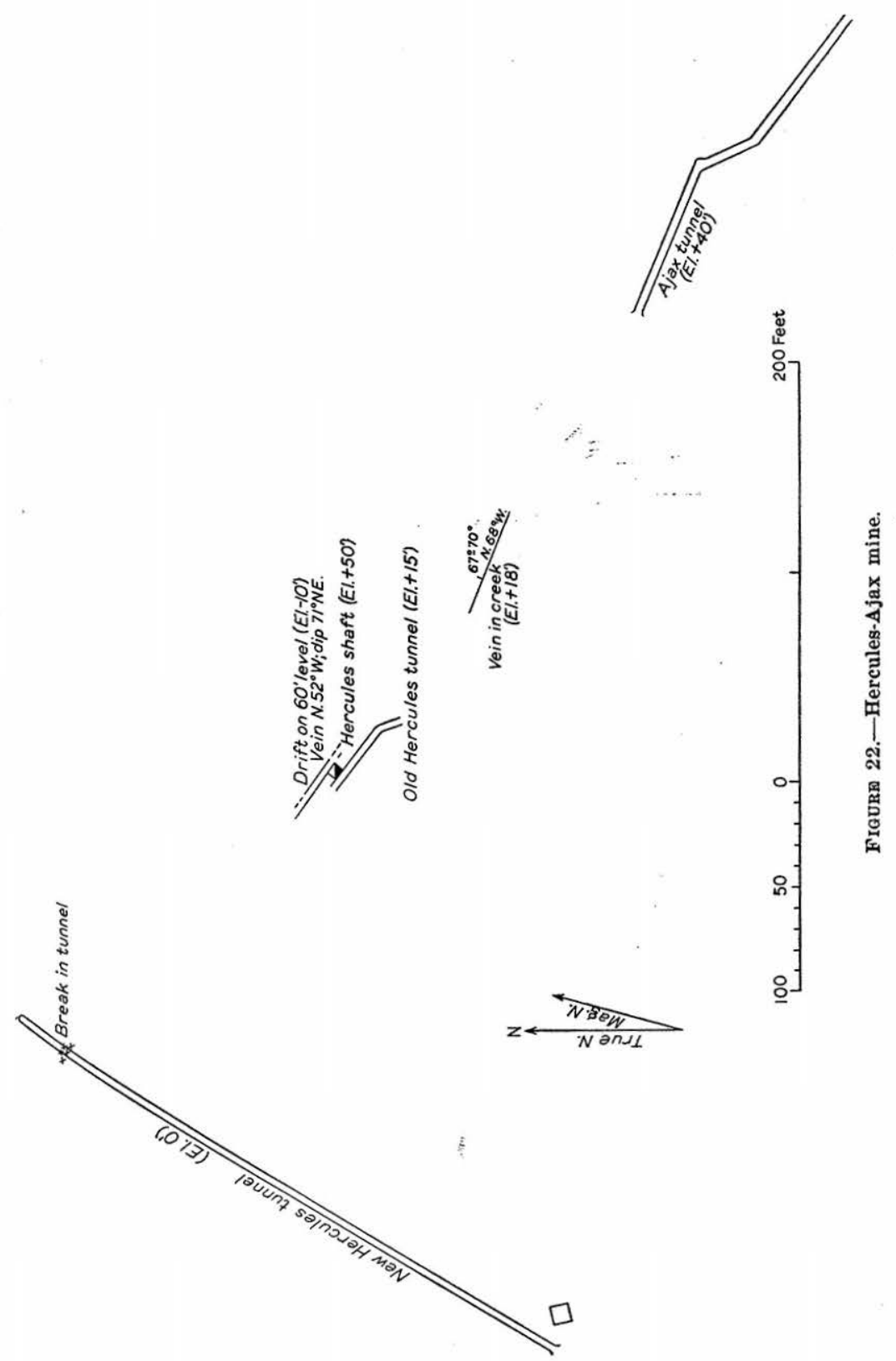

The hanging wall or east side of each fault moved up 15 to 20 feet with respect to the west side. 
The vein is very well developed and exposed in the channel of the stream, where it consists of a band of massive quartz with pyrite 6 to 24 inches wide. Both here and underground, however, the economic sulphides are confined to a band less than 6 inches wide in the massive quartz, which carries no valuable metals.

The sulphides observed are sphalerite, galena, chalcopyrite, pyrite, and a few grains of tetrahedrite (gray copper) scattered in a gangue of quartz and calcite with some fluorite. The pockety character of the vein does not offer much inducement for further prospecting except possibly to examine its intersection to the south with the limestone of Niobrara age on the surface. Outcrops of this limestone in the area are poor and discontinuous so that only its general course and attitude could be mapped, and the contact as shown on the geologic map (pl. 1), therefore, cannot be relied upon to include details of structure.

\section{TREASURY MOUNTAIN}

Eureka mine.-The Eureka mine is a few hundred feet below and southwest of the peak of Treasury Mountain, at an altitude of about 13,200 feet. It can be reached from Marble by a trail in the valley of Yule Creek and also from Crested Butte by a trail up Slate Creek. The distance from Marble is 12 miles and from Crested Butte 18 miles. Little is known regarding the total production of this mine. However, in the early days it apparently attracted more attention than any other prospect in the area, as may be judged from the following quotations : ${ }^{82}$

Eureka on Treasury Mountain *** put in shape for production; * * * ore of two grades, the first runs 65 to 110 ounces silver and 8 to 12 percent copper; the second runs 22 ounces silver and 24 percent lead. $* * *$ The Eureka $* * *$ has produced more than any other mine in the Elk Mountains. Several carloads of various grades of ore were shipped to Boston \& Colorado Works, which averaged about $\$ 300.00$ in gold, silver, and copper. The galena and antimonial silver ores were shipped to Kansas City and assayed 25 ounces silver and 60 percent lead.

Recent attempts to work the property have failed, owing chiefly to prohibitive costs of transportation to and from the railroad.

Essentially nothing is known about the extent of developments. The Eureka mine as it is locally known refers specifically to the tunnel near the old bunkhouse and ore bin. This tunnel, however, is full of ice the year around. About 500 feet below are several open cuts and a 50-foot tunnel along a bed. A short distance northwest of the mine and a few hundred feet east of the divide are additional old workings, all inaccessible. To judge from the character of the ore on the dumps, the shipments of 1883 referred to by Burchard may represent an accumulation from several prospects rather than from one ore body.

\footnotetext{
22 Burchard, H. C., Report of the Director of the Mint, 1883, pp. 240, 308-328, 1884 .
} 
Mineralization occurred in the upper part of highly metamorphosed Hermosa (?) strata only a few hundred feet below the Jurassic, all but a few hundred feet of the Maroon beds being cut out at the angular unconformity at the base of the Jurassic beds. Several small and very irregular quartz veins are present, but welldefined fissures are lacking. The small veins cut across the bedding and apparently were not considered of economic importance, as they have not been prospected. Development in several places has been clearly directed parallel to the beds along two or three horizons, which show mineralization at their outcrops. It seems, therefore, that the form is that of bedded deposits. Unfortunately the size and extent of any one ore body could not be determined.

Dark-brown sphalerite, chalcopyrite, and galena with a gangue of quartz and fluorite are common, though in varying proportions, on all the dumps. Hearsay reports claim very rich tetrahedrite (gray copper) ore. The antimonial silver referred to in 1883 by Burchard supports such claims, but none was found by me. Hedenbergite is present, and chalcopyrite is common on the dumps. These two minerals are characteristic of the North Pole mine, and their presence suggests a similarity in the mineralization of the two localities.

Head of Yule Creek.-At the head of Yule Creek are two interesting prospects. One is about three-quarters of a mile west of the Yule Creek-Slate River pass, at an altitude of about 11,500 feet, on the south side of the valley. The other is about half a mile farther west and 100 feet lower.

The first prospect referred to shows an exposure 2 to 6 feet thick and 20 feet long of massive sulphides in a shallow open cut. It is marked by an abundance of limonite stains at the surface, which helps to distinguish it from several other small and less important prospects nearby. The mineralized zone is about 30 feet above the base of the Jurassic. Pyrite and sphalerite with some galena and chalcopyrite constitute the sulphides. A definite vein could not be recognized, although there is some evidence of a small fault that strikes N. $70^{\circ} \mathrm{E}$. and dips $60^{\circ} \mathrm{NW}$., or approximately parallel to the surface. The maximum displacement cannot be more than a few feet and may represent a mere surface slip rather than a fault. The exposure suggests replacement of undetermined extent along a bed.

The second prospect is in the Parting member of the Chaffee formation (Devonian). Here there are several small pits and tunnels, of which the largest is a tunnel about 15 feet long in or just above the basal quartzite bed of the Parting member. The tunnel follows a small fault that strikes $\mathrm{N}$. $75^{\circ} \mathrm{W}$. and dips $75^{\circ} \mathrm{N}$., along which the north side moved up about 5 feet. The fissure contains irregular masses of pyrite with fluorite and quartz, as well as small local 
segregated bodies of sphalerite and chalcopyrite. Quartzite and hornfels, which compose the country rock, are stained brown and black for about 20 feet on each side of the fissure. In the dolomite above the Parting member the fissure is barren at the outcrop, and it could not be traced far below the tunnel. A few hundred feet to the west and at the same horizon are similar fault fissures that also show mineralization; none, however, show any mineralization at the surface either above or below the Parting member. Little ore is exposed at the outcrops, and the prospecting done is too scant to show whether ore occurs farther in on the vein. These prospects show encouraging amounts of sulphides, but further development can scarcely be justified because of the unfavorable location with respect to transportation facilities.

\section{PARADISE PASS AND VICINITY}

Paradise Pass is a saddle between a tributary of Rock Creek and the : Slate River south of the limits of the area mapped. At the pass and to the north there has been some mineralization, but 'no ore seems to have been produced from this locality. Several dumps that mark the position of caved shafts or tunnels are all that remain as evidence of prospecting in the area.

Mancos shale and diorite which has been intruded into the shale compose the country rock. Both contain veins of sulphides. The shales are indurated and contain much disseminated pyrite. Baldy and Cinnamon Mountains, rising to the east and west of Paradise Pass, are made up of shale that is superficially coated with limonite, a reddish-brown oxidation product of the pyrite, and from a distance they appear red. Individual specimens do not appear highly stained, so the strongly colored appearance of the two mountains is doubtless due to the uniform distribution of limonite over a relatively large area. The limonite stain is not related to sulphide mineralization of the veins. Metamorphism of the shale and the development of pyrite are like the metamorphism of Morrison shales around Treasure Mountain.

The fault zone so prominent on Galena Mountain trends toward this area, and although the displacements of the faults decrease materially in the Mancos shale south of Rock Creek, there can be little doubt that fracturing continued at least as far as Paradiso Pass. The character of mineralization is like that in Rock Creek and on Galena Mountain, to the north, but the veins appear more irregular and seem to have even less continuity. The predominant trend of the veins is approximately north, or in line with the trend of the main fault zone of Treasure Mountain. Only small amounts of the economic sulphides were found on the old dumps, and early prospectors apparently found little to encourage their efforts. 
The Bennet tunnel is a prospect at an altitude of 12,300 feet just vortheast of Mount Belleview and east of Schofield Pass. The most direct trail to it branches from the road a few miles north of Gothic. Gothic is 5 miles south of Schofield Pass, in the valley of the East River, and is outside the limits of the area mapped. The chief value of the ore is in silver, of which a few thousand dollars' worth is said to have been produced. A tunnel about 250 feet long on a vein represents the only important development work done. Several small pits nearby do not show mineralization.

The country rock is felsitic porphyry and Mancos shale, locally altered to hornfels. A vein extends $\mathrm{N}$. $50^{\circ}-55^{\circ} \mathrm{E}$. with essentially a vertical dip from the shale into the porphyry and crosses the contact nearly at right angles. As far as could be determined mineralization was confined to this vein. The fissure that marks the course of the vein on the surface is a conspicuous feature in the bluffs of porphyry only a few hundred feet above the line of the tunnel. From this fissure on the surface it is evident that the vein is narrow, though the character of the vein is not well exposed. In the tunnel the vein is continuous, though not more than 6 inches in average width, and consists largely of calcite with spots and small lenticular masses of galena lining the vugs that are present locally. The silver, however, is not associated with the galena. It occurs along both walls of the vein in streaks, less than 1 inch wide, of black earthy mineral containing nodules of tetrahedrite (gray copper) stained green with malachite. Material selected from these streaks is reported to assay several hundred ounces of silver to the ton. Qualitative tests of the tetrahedrite gave a very copious precipitate of silver chloride. In view of the high cost of transportation and mining, due to the unfavorable location of the prospect, it is doubtful whether such a narrow vein of silver-bearing tetrahedrite can be mined at a profit with ordinary prices of the metal.

Plate 1 shows that this prospect is more or less outside of the main mineralized zone. It is no closer to this mineralized zone than it is to a mineralized area to the southeast, on White Rock Mountain.

\section{MOLYBDENITE PROSPECTS}

The occurrences of molybdenite in the area are too scant to be of economic importance. They do not show any direct relation to the other sulphides.

Molybdenite is reported near Paradise Pass and on Yule Creek by Worcester. $^{83}$ The molybdenite near Paradise Pass, supposedly oc-

\footnotetext{
Worcester, P. G., Molybdenum deposits of Colorado: Colorado Geol. Survey Bull. 14, D. 68-67, 1819.
} 
curring in a quartz vein, was not seen by Worcester, nor could it be located by me. Molybdenite was found in two places on Yule Creek about a mile west of the extreme head of the valley. One deposit is on the north side of the valley at an altitude of 11,700 feet, or about 800 feet above the stream. Here two quartz veins in the pre-Cambrian gneiss contain molybdenite in scattered flakes, which are confined to a few streaks only one-half to 1 inch in width. A few thin plates of molybdenite an inch across were found, but the average is less than one-third this size. The veins strike N. $35^{\circ} \mathrm{E}$. and dip $75^{\circ}$ NE., parallel to the banding of the gneiss. Although prospected by only one or two shallow pits, the surface exposures are excellent, and the slight extent of the veins is evident.

The second occurrence of molybdenite is on the opposite side of the valley near the gneiss-granite contact, at an altitude of about 10,900 feet, 50 to 100 feet above the stream. A few scattered flakes of molybdenite were found in the Treasure Mountain granite in a pegmatitic stringer less than a quarter of an inch wide and within a few inches of the contact. There was no indication of alteration of any part of the granite, either in hand specimen or in thin section, and the molybdenite had the aspect of a primary mineral. In the gneiss a few hundred feet south of this occurrence a little molybdenite was found in massive quartz of what appeared to be an irregular vein, the strike and dip of which were not evident. Outcrops of the gneiss are not continuous, but the surrounding scattered exposures of it indicate that the amount of molybdenite is small.

\section{MARBLE DEPOSITS}

\section{YULE COLORADO MARBLE}

\section{SUMMARY}

The recrystallized limestones and dolomites on Treasure Mountain include a great variety of marbles, only one of which-the Leadville limestone, of Mississippian age-has been productive. Serpentine marble of the Ordovician (Manitou dolomite) has small commercial possibilities: test blocks of it have been quarried at the head of Yule Creek, but it is not sufficiently distinctive to compete under existing circumstances with serpentine or verde antique marbles now on the market. The Devonian and Pennsylvanian marbles are too thinbedded to be of commercial interest, and their more attractive colors and textures are not uniformly developed. The marble produced in the district has come entirely from one quarry on Yule Creek about 3 miles from Marble. It is known to the building industries both as Colorado Yule and Yule Colorado marble. This quarry was opened by the Colorado Yule Marble Co. and operated continuously from 1908 to 1916 , when the company failed. Thereafter the property underwent several changes in ownership, but little quarrying was: 
done until 1928, when the Yule Colorado Marble Co. was organized as a subsidiary of the Vermont Marble Co. to operate the quarry. Since 1928 a moderate quantity of marble has been marketed each year.

The Yule Colorado marble is white, medium-grained, and generally banded with pale-brownish streaks which in places contain angular fragments of ehert. These features are the basis for the following commercial classification: (a) "Statuary", which closely resembles the Pentelic marble of Greece; (b) "second statuary", in which markings are inconspicuous; $(c)$ "golden vein", in which the brownish streaks are conspicuous; $(d)$ "crystal grade" (discontinued in 1936), in which chert fragments as well as brown and less commonly dark-gray streaks are present in a groundmass that may be either gray or white. The original company subdivided the streaked or "veined" marble into "golden vein", with brown sțreaks, and "Colorado cloud", with dark-gray streaks. As the brown streaks represent oxidation of minute pyrite grains that are present in the dark gray, these two varieties grade into each other. The statuary grade commands the highest price, and the crystal grade the lowest. The difference expresses both relative attractiveness and costs of quarrying and selection; each grade is considered equally durable as a building stone. It is said that the marble of statuary grade is available in larger dimensions in this quarry than in any other quarry in the United States. "Golden vein" and "second statuary" grades are represented on plates 21,22 , and 23 . The local reserves of commercial marble are very large, and the capacity of the present quarry equipment has exceeded the market demands for many years.

A mill for finishing marble is located at Marble, and both finished and unfinished marble are shipped to many parts of the United States, but more to the Pacific coast than to the East. The location of the quarry prevents extensive use of the marble in the principal markets, which are in the East and are more readily supplied with marble for most purposes from the Appalachian States.

\section{HISTORY AND DEVELOPMENT}

Exposures of marble are conspicuous both on Yule Creek and on the Crystal River (called Rock Creek in old reports) between Marble and Crystal, and these exposures were probably noted by the earliest explorers to enter the area. The first reference in the literature to the marble deposits in the area was made in $1882^{84}$ in "Mineral Resources of the United States", which in succeeding years recorded bits of information concerning development of the district. In the report for 1885 , for example, we are told that "a bed of remarkable fine marble was opened up during this year on one

\footnotetext{
${ }^{84}$ Geol. Survey Mineral Resources, 1882, p. 454. 1883.

$131028-37-11$
} 
branch of Rock Creek." This statement apparently referred to exposures of marble at the head of Yule Creek. We are further told that the representative of the Union Pacific Railroad who examined the deposits reported that all tests "proved in the highest degree satisfactory." The statement continued by saying that although marble was found in abundance it was not considered practicable to develop the deposits because of difficulty of access. Unfavorable location has continued to be the most severe handicap to the development and operation of quarries.

The first approach of a railroad came with development of coal at Crested Butte. Eventually the railroad was built to Pittsburg, on the Slate River only 6 miles south of the head of Yule Creek. By $1895^{85}$ a railroad grade was actually built to the head of the creek. Up to this time the deposit of marble at the head of Yule Creek seems to have been considered the best, if not the only one of importance in the area. However, just as the coal industry brought one railroad to Pittsburg on the south, so coal in Coal Basin brought another to Redstone, which is on the Crystal River about 12 miles north of Marble (in early days called Marble City). This railroad was later extended to Marble.

The marble is exposed along the lower part of Yule Creek and in the valley of the Crystal River 3 to 4 miles from Marble. The marble is of the same character in both places, but the outcrops on Yule Creek are the more prominent and have been more extensively developed. At the head of Yule Creek, 11 miles from Marble, the altitude is about 12,000 feet and convenient power is not available, whereas on lower Yule Creek the deposits are at an altitude of about 9,000 feet, and water power is available from both the Crystal River and Yule Creek.

The first record of production is in Mineral Resources for $1896{ }^{86}$ which states, "At the present time (Mareh 1897) Colorado is engaged in producing marble for a public building in Denver, $* * *$ but it is doubtful if any considerable amount was taken out in 1896." Authentic records show an output in 1897 valued at $\$ 99,600$, and in 1899 at $\$ 10,766$. After 1899 no output was recorded until $1908,{ }^{87}$ when a quantity estimated at 30,000 cubic feet and valued at $\$ 55,400$ was sold. ${ }^{88}$ About this time the stock of the Colorado Yule Marble Co. was widely advertised for sale, and an immense sum was spent while development was in progress. During 1909 Colorado, through the activities of the Colorado Yule. Marble Co., rose from tenth to fourth in rank among the States as a producer of marble. It

85 Underhill, G. W., Colorado marble: Stone, vol. 11, pp. 1-5, 1895.

${ }^{80}$ Geol. Survey 18th Ann. Rept., pt. 5 (continued), pp. 978-979, 1897.

${ }_{87}$ Geol. Survey Mineral Resources, 1908, pt. 2, p. 561, 1909.

8 These and other figures of output have been supplied by Miss A. T. Coons, of the Bureau of Mines, and are published by permission of the Vermont Marble Co., the present ,owner. 
retained this rank until 1916, when the company, unable to liquidate the large debt incurred during development and confronted with a decreased demand for marble incident to the World War, went into the hands of receivers. During the period 1908-17 the company shipped 1,142,500 cubic feet of rough and finished marble, valued at $\$ 5,422,100$. The annual average value increased steadily from $\$ 1.85$ a cubic foot in 1908 to $\$ 6.63$ a cubic foot in 1914 , when finished marble was shipped to Washington, D. C., for the Lincoln Memorial. Thereafter the average value declined, and shipments ceased in 1917.

The property remained idle during 1918 , and in 1919, according to newspaper reports, it was sold at sheriff's sale to a junk dealer; but it was purchased in the same year by persons who, reluctant to see the equipment scrapped, organized as the Yule Marble Co. of Colorado. It was not until 1922, however, that this company resumed operation of the mill and sold 2,800 cubic feet, valued at $\$ 12,000$, from old stock stored at Marble. In 1923 the quarry was taken over by the Carrara Yule Marble Co., which quarried some: stone marble but was succeeded in the same year by the Colorado Consolidated Yule Marble Co. In 1924 the property was evidently leased to the Tennessee-Colorado Marble Co. and was operated by the Gray Knox Marble Co., of Knoxville, Tenn. During 1923 and 1924 sales amounted to 99,383 cubic feet, valued at $\$ 572,862$, and the average value per cubic foot of different shipments ranged from $\$ 1.95$, presumably for rough stock, to $\$ 8.63$ for the more expensively finished stock. The Colorado Consolidated Yule Marble Co. retained ownership and sold considerable marble until late in 1928, when the property was sold to the Yule Colorado Marble Co., in which the Vermont Marble Co., of Proctor, Vt., held a half interest. In 1929 the Vermont Marble Co. became sole owner, although the Yule Colorado Marble Co. continued as a subsidiary. Sales of rough and finished marble for exterior and interior building and for monumental work have been made in every succeeding year up to the present (1936). The sales since the reopening of the property in 1922 have amounted to 232,553 cubic feet, valued at $\$ 1,107,577$, and the average value of rough and finished marble has been $\$ 4.76$. a cubic foot, practically the same as that for the earlier period.

Other companies that attempted to develop marble quarries in the district never attained production. One, the Strauss quarry interests, constructed a long inclined track but developed no sound marble. The Colorado White Marble Co. drove a tunnel on the west flank of Whitehouse Mountain about a mile north of the main quarry, crosscutting Pennsylvanian beds to intersect the marble. The tunnel did not reach its objective, but two diamond-drill holes from; the: 
face of the tunnel are said to have entered a promising grade of marble.

The fundamental factor in the vicissitudes of the marble industry on Yule Creek can be found in the location of the deposit, although the early management of the initial company may have been a contributing factor; according to reports, money was spent too lavishly during the development stage. Owing to location the cost of production in the Yule Creek district and the cost of transportation to most of the larger markets were greater than in the eastern districts. Counteracting features, however, were the high quality and attractiveness of the better grades of the marble. The Yule Colorado marble has been regarded by the trade as one of the best of the "white marbles", and rough specimens of the statuary grade are practically identical with the famous Pentelic marble of Greece. No other domestic quarry, it seems, can furnish such large blocks of pure white or statuary marble, and it was for this reason that this marble was selected for the Tomb of the Unknown Soldier in Arlington National Cemetery.

\section{PUBLISHED AND UNPUBLISHED REPORTS}

Although the marble deposits of the district attracted considerable attention, even at early dates, only two short descriptions have been published, ${ }^{89}$ other than the generalized statistical statements in Mineral Resources and occasional notes in trade journals. Lakes, in his earlier description, emphasizes the great variety in color of marble at the head of Yule Creek in a stratigraphic section 750 feet thick, which evidently included Ordovician, Devonian, and Mississippian formations. In his later article, after the quarry in lower Yule Creek had been opened, he described the marble as 200 feet thick, with 40 percent of pure-white statuary marble and the rest clouded, dove-colored, and green serpentine varieties.

An unpublished report by George P. Merrill, based on an examination for the Colorado Yule Marble Co. in August 1914, has also been available. Merrill briefly considered the geology of the marble formation, including a serpentine marble, evidently in the Ordovician beds of upper Yule Creek. Unfortunately all the illustrations, including the measured section, were missing from his report. Chemical and physical tests from Merrill's report are quoted on pages $160,161$.

\section{DISTRIBUTION}

In extent and distribution the marble is coextensive with the Mississippian (Leadville) limestone. (See pl. 1.) This formation is cut out on Yule Creek by the angular unconformity at the base

${ }^{8}$ Lakes, Arthur, Colorado marble: Stone, no. 3, pp. 213-222, 1895; Some remarkably fine marble quarries of Colorado: Min. World, vol. 32, pp. 609-611, 1910. 
of the Jurassic and is cut out on the Crystal River by the intrusive granite mass of Treasure Mountain.

Although the entire formation as exposed is recrystallized to marble, only a minor part of it is marketable. The exposures that extend from the head of Yule Creek to Bear Basin are too unfavorably located with respect to transportation to be profitably developed under present market conditions. Much unavailable marble also occurs in the band of conspicuous outcrops on the dip slope across the west flank of Treasure Mountain. These outcrops are so much fractured and iron-stained from surface weathering as to discourage development. The Strauss quarry is in the lower part of this dip slope. Below the dip slope, where the Mississippian passes under the cover of Hermosa (?), marble of marketable quality may be expected. On the Crystal River south of Twin Bridges the marble lies favorably for development and appears relatively free from defects. Both of these localities are as close to the town of Marble as the quarry on Yule Creek and are at no higher altitude.

PRINCIPAL FEATURES OF THE MARBLE FORMATION

The Mississippian limestone in the district is characterized by its massive structure and by the prominent bluffs or cliffs in which it is exposed. On and around Treasure Mountain recrystallization of the limestone into medium-grained white marble has accentuated the massive character of the formation. Massive marble cliffs over 150 feet high are common. In detail the formation shows certain variations, the most conspicuous of which are the gray, buff, and white dolomite interbedded with marble in its lower part (see pl. $3, A$ ) and the presence of stringers of chert and irregular masses of dolomite in marketable marble in its upper 60 to 100 feet.

In the old Strauss quarry a single bed of chert 2 feet thick is exposed. In the Yule Colorado marble quarry chert stringers are usually less than an inch thick but are sufficiently numerous to constitute a problem in quarrying. The chert does not occur in continuous layers of appreciable length but forms closely or moderately spaced angular fragments (pl. 19, $A$ ) commonly as much as 4 inches in length and an inch or less in thickness. Rows of these fragments may extend for several feet and apparently represent lenticular layers of chert that were fractured and stretched apart during regional folding and the later arching and recrystallization of the marble over the granite stock of Treasure Mountain. The major dimensions of the chert fragments are parallel and in line with the direction of stretching, which is interpreted as evidence that stretching has been parallel to the original bedding planes. This conclusion is further supported by the fact that the stringers of chert lie in the plane of cleavage or grain of the marble. 
In addition to the dolomite beds in the lower part of the Mississippian there are light-gray to buff masses of dolomite and of diopsidequartz aggregates in the upper part. These masses are referred to by the operators as "lime." Although the dolomite and diopsidequartz aggregates occur in the same part of the quarry, they do not appear to have formed at the same time.

They have been seen only in the quarry, as they are very inconspicuous on weathered surfaces and are easily overlooked. The dolomite masses are irregular in form, and those of diopside and quartz are more lenticular. Both are in zones generally parallel to the chert. stringers and the direction of cleavage. They are detrimental because they are comparatively hard and brittle, are much fractured, and have an unattractive gray color. The true character of the dolomite is only poorly shown on natural surfaces. but is clearly defined in several large sawed blocks that have been set aside at the mill as waste. Some of these are shown in plate $20, A$, which illustrates the irregular form of these bodies of dolomite and the character of the accompanying fractures. The fractures may be open or they may be tight seams, as in plate $20, A$, but they are invariably transverse to the bedding. Rhombohedral crystals of calcite line many of the open fractures and fill some of them. A few quartz crystals are also present in some of the fractures. Finer-grained calcite replaces the dolomite walls along these fractures. The replaced parts may bo either irregular or more uniform. In the specimen shown on plate $20, A$, the fractures themselves are not sharply defined but are marked by the white streaks, two of which are relatively wide and clearly shown and one of which is very thin and extends from the point of the hammer. The dolomite is finer-grained than the calcite. This difference is readily recognizable by the unaided eye, as well as under the microscope. Even in those places where the dolomite grades to calcite and the grain appears to be coarser than the average, the dolomite proves to be finer-grained than the surrounding calcite. This change from dolomite to calcite appears to be as gradual under the microscope as it does in plate $20, A$.

The features described and illustrated on plate $20, A$, are interpreted to mean that calcite has replaced dolomite. As the dolomite is fine-grained and gray, it is regarded as a dolomitic zone in the limestone, which was present before recrystallization of the limestone was completed. The fractures suggest tension, and they have probably resulted from the stretching of the beds indicated by the fractured bands of chert. In dolomitic rocks such fractures could be preserved, whereas in the limestone or marble they would be obliterated during recrystallization of the calcite. The fractures cannot be traced beyond the limits of the dolomite. However, in places veinlets of coarse calcite that fill these fractures can be traced 
for several inches beyond the boundary of dolomite into the white marble before they merge into the surrounding calcite.

The diopside and quartz are concentrated in fairly well defined lenticular masses. They resemble the dolomite only in their gray color. Instead of having irregular and gradational boundaries like the dolomite, the diopside-quartz lenses have rather uniform outlines and well-defined boundaries. Furthermore, they are free of the fractures so characteristic of the dolomite. They are also much less common than the dolomite masses-in fact, they were found in only one place in the quarry. Some of the lenses seen in cut blocks of marble were 3 to 5 feet long and 2 to 12 inches thick. One end of a large lens and the parallel sides of a smaller one are shown in plate $20, B$. The diopside and quartz are intergrown with calcite, and all three minerals occur throughout the lenticular bodies, but the first two are more concentrated along the margins than in the central part, where calcite predominates. In places the central parts of the lenses consist mainly of white marble, but a small amount of diopside is invariably present. A secondary, hydrothermal origin of the diopside and quartz is suggested by local occurrences of dark-brown sphalerite or zinc blende along the border of the areas. The largest amount of sphalerite seen is shown in plate $20, B$. More commonly. it is present only in small isolated grains, some of which are not associated with diopside or quartz. The diopside-quartz bodies are avoided as much in quarrying as the dolomite and chert.

The massive marble possesses a well-developed grain or schistose structure and also contains pale-brown to dark-gray streaks or "veins." The grain and streaks are parallel to the stringers of chert. Many of the brown streaks are so faint as to be virtually invisible on fresh fractured surfaces, but on polished surfaces they show as "veins" of soft and delicate shades. (See pls. 21, 22.) Marble of this character is classed as "golden vein" and is the principal product of the quarry.

The grain of the marble, even when well developed, is inconspicuous in small specimens but is readily discernible by the relative ease with which the marble fractures along one plane as compared with other directions. Thin sections under the microscope show that the length of the calcite grains is usually at least twice their width. The grain is an expression of schistosity, and marble fractures easily along it, whereas fracturing is more difficult in planes parallel to the dip and perpendicular to the strike of the marble formation and is most difficult in planes normal to both strike and dip. 


\section{COMPOSITION}

The Yule Colorado marble is predominantly calcite. The dolomite, chert, diopside, quartz, and sphalerite already referred to constitute only a very small part of the marble as a whole. In addition to these minerals a very small amount of fuchsite, green chromiferous mica, is present. This mineral is described in Merrill's report. It occurs in small irregular seams in one place in the quarry. In thin section the mineral exhibits a bright-green color without any apparent crystal structure.

Acid tests and microscopic examination show that the marble consists of remarkably pure calcite over relatively large areas. This fact is also shown by the following chemical analyses taken from Merrill's report:

\section{Chemical analyses of Yule Colorado marble}

[Made under direction of A. W. Smith, Case School of Applied Science, Cleveland, Ohio, Oct. 22, 1907]

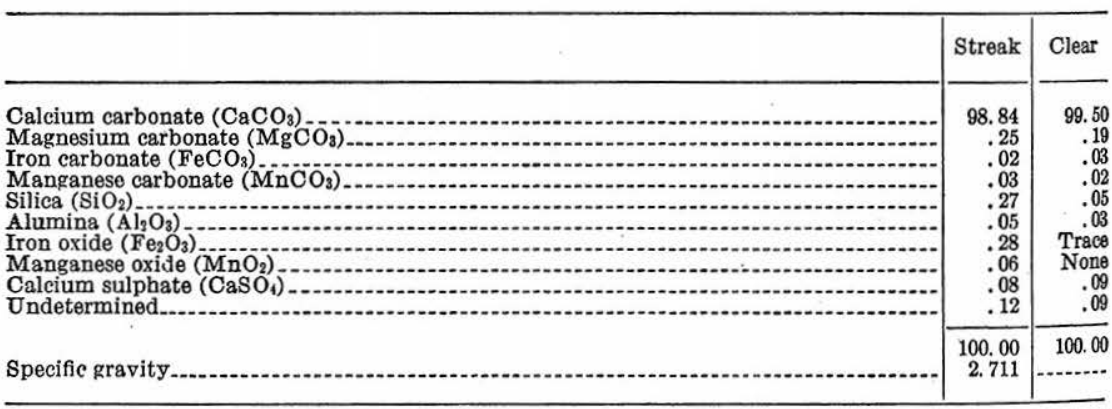

The "streak" represents the markings in the "golden vein" marble. Its analysis shows that the color is due chiefly to iron oxide.

The important detrimental impurities, chert, dolomite, and the diopside quartz aggregates, were practically absent in the two samples analyzed, as is shown by the trivial quantities of silica and magnesium carbonate. The amounts of sphalerite, galena, and chalcopyrite throughout the deposit are too small to be important. Brown and red iron-stained marbles are common in places near the contact with the overlying Pennsylvanian (Hermosa? formation).

\section{PHySICAL PROPERTIES}

Merrill's report ${ }^{90}$ includes the physical tests given below, but does not indicate the parts of the formation from which the test pieces were taken. (See p. 156.)

\footnotetext{
${ }^{\infty}$ Merrill, G. P., A report on the Colorado Yule marble properties, 1914. [Manuscript
} report to Lincoln Memorial Commission.] 


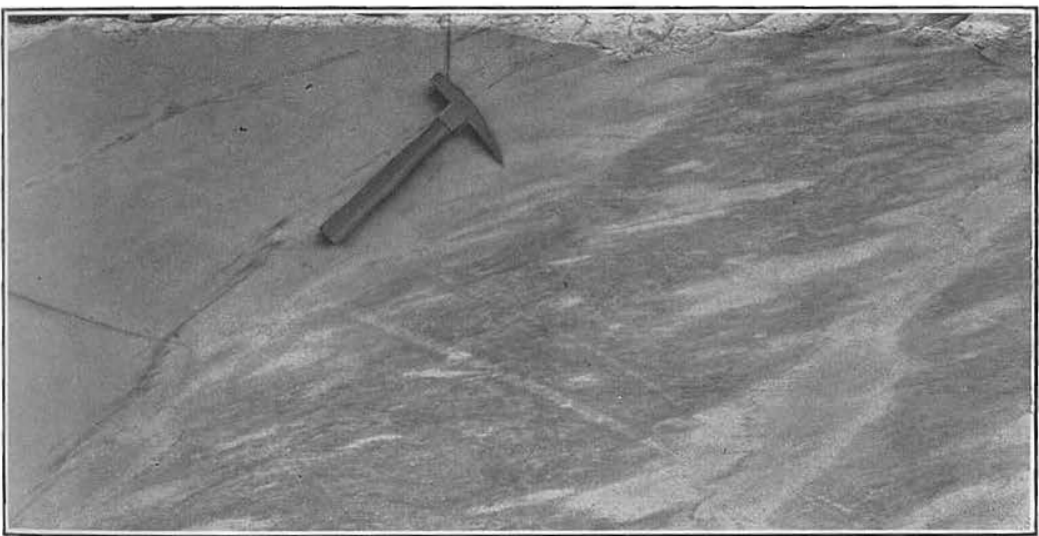

A. IRREGULAR MASS OF DOLOMITE (GRAY) IN WHITE CALCITE MARBLE.

Note the gradational boundaries. The white streaks nearly perpendicular to the hammer handle extend along small fractures.

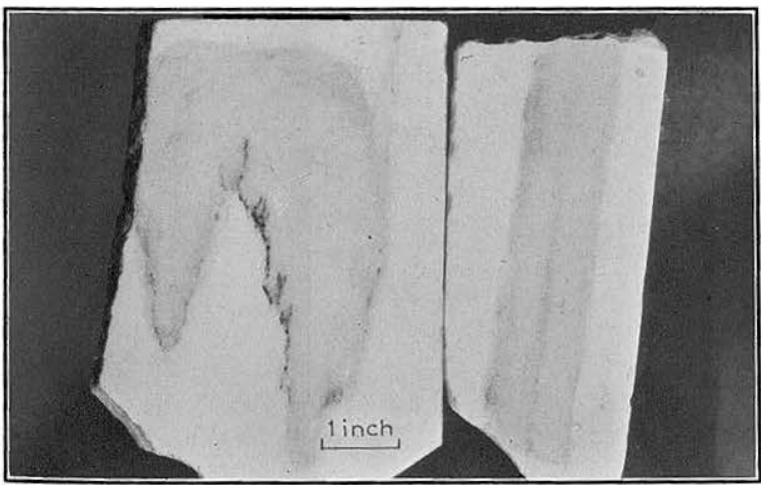

B. CROSS SECTION OF PARTS OF A LENS OF DIOPSIDE AND QUARTZ.

Piece at right is end of lens that was about 4 feet long. Black is sphalerite. Piece at left shows parallelism of sides. (See pl. 12, B.) 


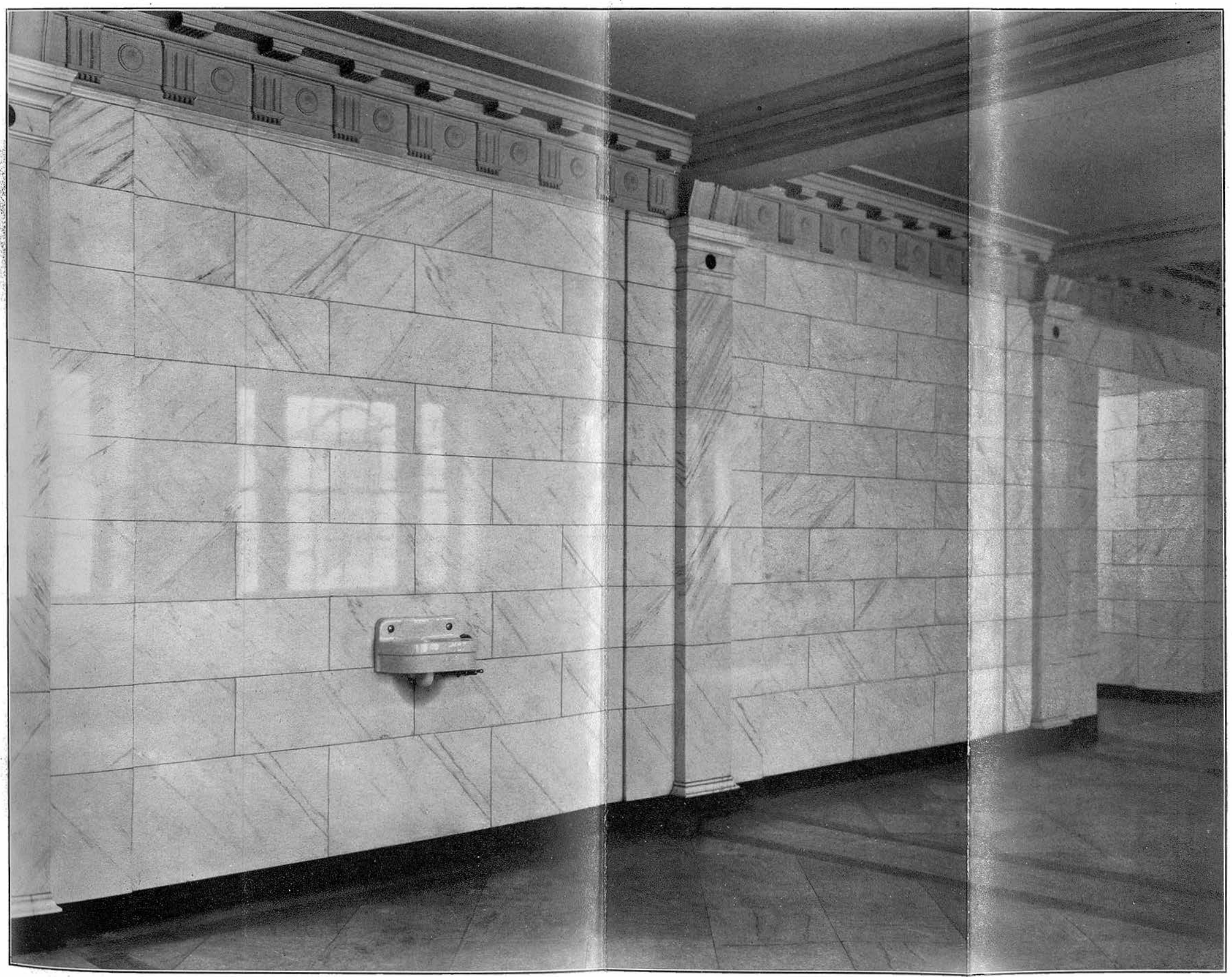

"YULE GOLDEN VEIN" ASHLAR, WITH "BELGIAN BLACK" BASE Providence County Courthouse, Providence, R. I. Courtesy of the Vermont Marble Co. 


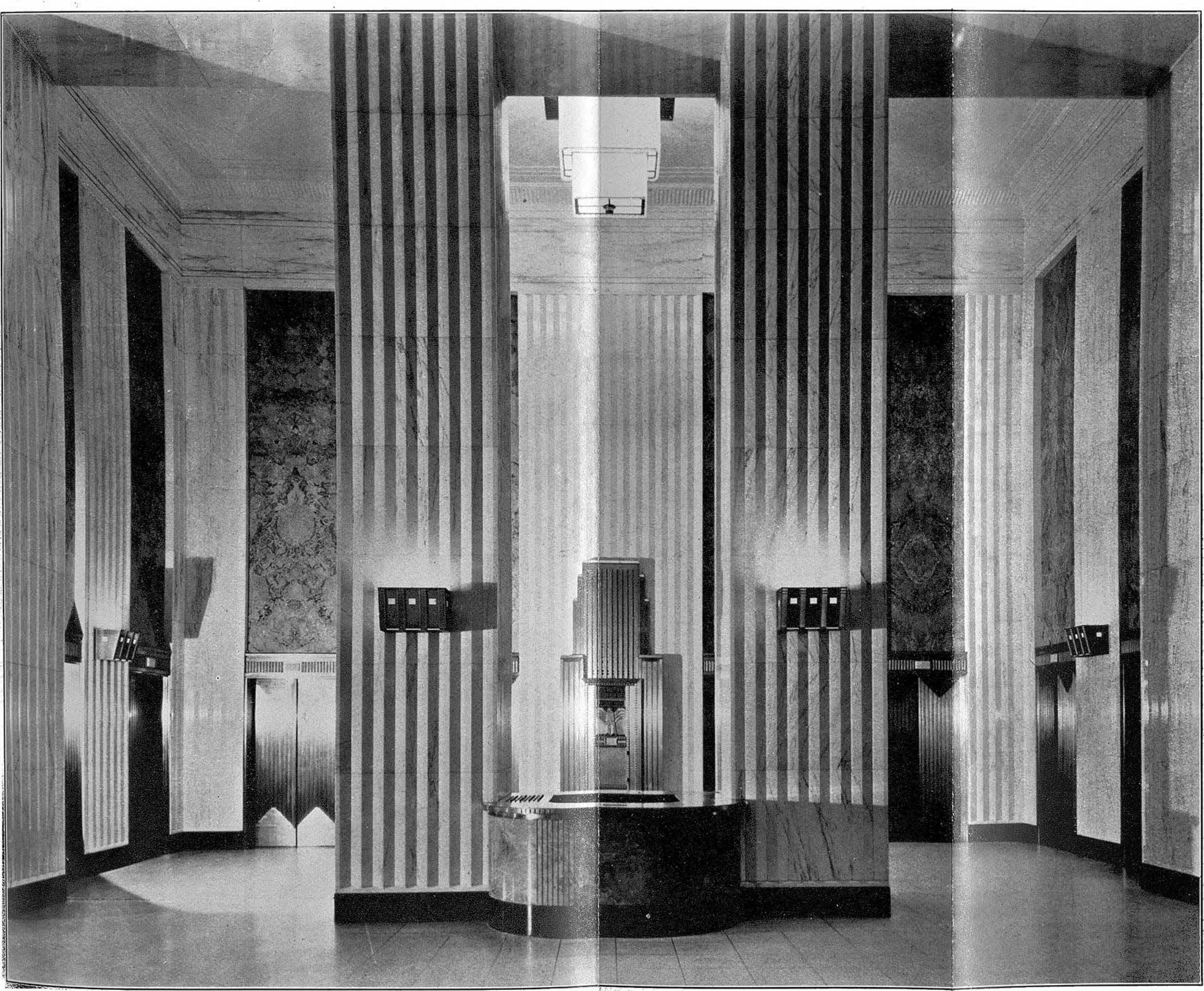

"YULE GOLDEN VEIN" FLUTED PILASTERS AND FRIEZE COURSE, WITH "LOREDo ChIARO" PANELS AND "BELGIAN BLACK" BASE. Field Building, Chicago, III. Courtesy of the Vermont Marble Co. 
Results of absorption tests on 3 -inch cubes

[Test 14234, Bureau of Standards. Washington, D. C., Nov. 3, 1913]

\begin{tabular}{|c|c|c|c|}
\hline Cube no. & \begin{tabular}{|} 
Dry weight \\
(grams)
\end{tabular} & $\begin{array}{l}\text { Absorption } \\
\text { after im- } \\
\text { mersion for } \\
48 \text { hours }{ }^{1} \\
\text { (gram) }\end{array}$ & Ratio 2 \\
\hline 1. & $\begin{array}{l}1,295.99 \\
1,308.00 \\
1.258 .56\end{array}$ & $\begin{array}{r}0.79 \\
.84 \\
.96\end{array}$ & $\begin{array}{r}0.00061 \\
.00064 \\
.00076\end{array}$ \\
\hline
\end{tabular}

1 The very low absorption values of these specimens were rendered slightly uncertain by the rough faces of the cubes. The foregoing results have been corrected as far as possible for error due to tbis cause.

2 As usually stated in test records the figures in this column would be given as 0.061 nercert, etc.

\section{Compression tests}

[By Milo S. Ketchum, C. E., Dean, University of Colorado]

\begin{tabular}{|c|c|c|c|c|c|}
\hline \multirow{2}{*}{ Sample no. } & \multirow{2}{*}{$\begin{array}{c}\text { Height } \\
\text { (inches) }\end{array}$} & \multirow{2}{*}{$\begin{array}{l}\text { Cross section } \\
\text { (inches) }\end{array}$} & \multirow{2}{*}{$\begin{array}{l}\text { Area } \\
\text { (square } \\
\text { inches) }\end{array}$} & \multicolumn{2}{|c|}{ Load (pounds) } \\
\hline & & & & Total & $\begin{array}{c}\text { Per square } \\
\text { inch }\end{array}$ \\
\hline \multirow{2}{*}{ Average._._. } & $\begin{array}{l}1.95 \\
2.02 \\
1.97 \\
1.98\end{array}$ & $\begin{array}{l}2.02 \times 1.97 \\
1.98 \times 1.96 \\
1.98 \times 1.98 \\
1.98 \times 2.00\end{array}$ & $\begin{array}{l}3.98 \\
3.88 \\
3.92 \\
3.96\end{array}$ & $\begin{array}{l}38,660 \\
37,450 \\
40,990 \\
43,520\end{array}$ & $\begin{array}{r}9,710 \\
9,630 \\
10,450 \\
10,990\end{array}$ \\
\hline & & & & & 10,195 \\
\hline
\end{tabular}

Cross-breaking tests

[By Milo S. Ketchum, C. E., Dean, University of Colorado]

\begin{tabular}{|c|c|c|c|c|c|}
\hline Sample no. & $\begin{array}{r}\text { Length } \\
\text { (inches) }\end{array}$ & $\begin{array}{l}\text { Breadth } \\
\text { (inches) }\end{array}$ & $\begin{array}{c}\text { Depth } \\
\text { (inches) }\end{array}$ & $\underset{\text { (pounds) }}{\text { Load }}$ & Modulus \\
\hline 1. & $\begin{array}{l}6 \\
6 \\
6 \\
6\end{array}$ & $\begin{array}{l}2.01 \\
2.01 \\
2.00 \\
2.00\end{array}$ & $\begin{array}{l}2.00 \\
1.98 \\
2.01 \\
2.01\end{array}$ & $\begin{array}{l}890 \\
900 \\
870 \\
950\end{array}$ & $\begin{array}{r}1.000 \\
1.060 \\
.970 \\
1.100\end{array}$ \\
\hline 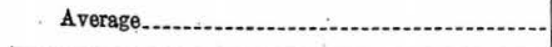 & - & -...en- & 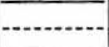 & - & 1.030 \\
\hline
\end{tabular}

Other data supplied by the National Bureau of Standards ${ }^{91}$ are as follows:

Replying to your inquiry of May 20 in regard to physical tests on Colorado Yule marble, we wish to advise that certain results were obtained on samples of this marble submitted for consideration in connection with the Lincoln Memorial, as follows :

Modulus of rupture, average of four tests, 1,200 pounds per square inch.

Compressive strength, average of twelve tests, 7,600 pounds per square inch.

Absorption, average of eight tests, 0.10 percent.

The modulus of rupture values were obtained on strips about 12 inches long, 2 inches wide, and $7 / 8$ inch thick, while the compressive strength and absorption values were obtained on blocks 2 by 2 by $\tau / \mathrm{s}$ inch. The compressive strength was determined by testing the blocks flatwise-that is, by applying the loads to

'r Letter to G. F. Loughlin, Geol. Survey, dated May 26, 1936. 
the 2- by 2-inch faces. Absorption tests were also made on three polished 2 -inch cubes submitted in addition to the above samples, and the average result was 0.13 percent.

When the memorial was being constructed some question came up in regard to the veining matter, and eight 9-inch cubes were submitted for compression tests. These were tested perpendicular and parallel to the direction of the veining, and the average compressive strength obtained was 9,800 pounds per square inch. The minimum value was 8,600 pounds per square inch and the maximum 10,800 . The compressive strengths obtained on the large cubes were surprisingly high compared with those obtained by testing smaller pieces flatwise, since one would expect higher strength for the latter shape.

Comparison with tests made at the Bureau of Standards ${ }^{92}$ on 50 commercial domestic marbles shows that the ratio of absorption of the Yule Colorado marble, as recorded on page 161 (top), ranks with the lowest recorded, whereas the 0.10 percent recorded on page 161 (bottom) is near the average, and the 0.13 percent is exceeded in 10 marbles. It is striking that the highest percentage should have been obtained with polished cubes, which one would expect to be less absorptive than unpolished samples, and the high percentage apparently represents pores, minute fractures, or other flaws too small to be detected when the cubes were prepared. It may be that the polished cubes represent the "east-side" marble, which is more permeable than the rest. The compressive and transverse breaking strengths, without allowance for differences in the apparatus used, are comparable with those of the weaker marbles, which include some of the most extensively used white or nearly white, well-crystallized marbles. The difference in strength between the large cubes and the smaller, flat samples also implies that the small samples were of originally less sound material or, because of their small size, were rendered less sound during preparation.

The texture of the commercial grades appears uniform as a whole, but there are exceptions of practical significance; for example, a small amount of relatively coarse-grained marble is present on the east side of the quarry 150 to 200 feet down in the pit and seems to be confined to this position. This variety is classed as "eastside" or "soft" marble not suitable for exterior use, except in protected places, as after a few years of exposure to weathering it begins to crumble and its polished surfaces lose their smoothness. Stratigraphically this horizon is 100 feet or more below the top of the formation and, locally at least, may mark the lower limit of commercial marble. Further work will be necessary to determine whether the "soft" stone represents a stratum of considerable extent, or whether it is a purely local feature and the result of obscure deformation that has rendered it comparatively porous and weak.

${ }^{92}$ Kessler, D. W., Physical and chemical tests on the commercial marbles of the United States: Bur. Standards Tech. Paper 123, pp. 34-50, 1919. 
The research department of the Vermont Marble Co. has recently given considerable attention to the influence of texture on the workability and durability of its marbles and finds that the degree of interlocking of grains and the width of spaces between grains are very influential factors in these respects. The degree of interlocking is conveniently expressed by a coefficient of irregularity which is based on the aggregate length of grain contact in a given representative area divided by the cube root of the number of grains in that area. Marbles with a coefficient of less than 8 are relatively incoherent and therefore subject to dissolution. Their porosity as well as their cohesive strength is likely to be affected adversely by different kinds of tool work. The soft or "east-side" marble cited above has a coefficient of only 7.05, whereas the coefficients of the more satisfactory marbles in the deposit range from 8.35 to 10 . Similarly the ratio of absorption of the "east-side" marble ranges from 0.20 to 0.30 , whereas that of the other marbles ranges from 0.10 to $0.13 .^{93}$

\section{COMMERCIAL OUTLOOK}

The cost of producing marble on Yule Creek is high compared with that in the marble districts of Georgia, Tennessee, and Vermont, owing to the high altitude, high relief, and especially the severe winter seasons; furthermore, the large quarries of white or nearly white marble in Vermont, Georgia, and Alabama have a distinct advantage as regards the largest markets, which are in the East, and those in Alaska furnish competition for markets in the Pacific coast and adjacent States. The Yule Colorado marble is advantageously situated with respect to the region between the Mississippi River and the longitude of Salt Lake City, in which, however, markets are comparatively small and widely scattered. Where competitive costs are subordinated to special féatures, such as large blocks of statuary stock, the Yule Colorado marble may reach more distant markets, but the demand for such special stock is obviously small and intermittent.

\section{QUARRIES AND PROSPECTS}

\section{STRAUSS QUARRY}

Many shallow pits have been dug by early prospectors on the outcrops of marble. The most extensive prospect, locally known as the Strauss quarry, is on the southwest slope of Treasure Mountain, where the Mississippian limestone, which contains the marble, forms an extensive dip slope and provides many exposures of white marble. The quarry is about 3 miles from Marble and 1,000 feet above Yule Creek, was served by a standard-gage railroad, and used electric power developed from water of Yule Creek. Several test pits were

\footnotetext{
${ }^{83}$ Information supplied by G. W. Bain, Vermon't Marble Co.
} 
made, none of which developed sound stone. Evidently the operators expected to find good marble a short distance below the surface, not realizing the necessity of following the dip of the formation. The test pits did not get below the fractures and stains produced by surface weathering. Good marble can be expected only where the marble dips under the overlying Pennsylvanian beds and is protected from weathering.

\section{YULE COLORADO MARBLE QUARRY}

"Yule Colorado marble" is the trade name for the product of the Yule Colorado Marble Co., which was organized in 1928 and was operating the quarry in 1935 as a subsidiary of the Vermont Marble Co. From 1908 to 1916 the marble was universally known to the trade as the "Colorado Yule marble." Less commonly the term "Yule marble" was used. The new name, "Yule Colorado marble", however, has been used in this report as a general name for all the marble in the Mississippian limestone of the area. Owing to the very uniform character of the marble, this description of the Yule Colorado marble quarry, with the exception of local and minor variations, is generally applicable to any part of the Colorado Yule marble.

The quarry is on Yule Creek $31 / 2$ miles from Marble, at an altitude of about 9,500 feet, and the finishing plant is at Marble. A standardgage electric railroad along the west and south side of Yule Creek connects the quarry with the mill and the steam railroad at Marble. The mill, trolley line, and quarry are operated by electric power developed at the company's plant about a mile west of the marble on the Crystal River. Water used to develop electricity is derived from the Crystal River and Lost Trail and Yule Creeks.

The quarry openings are a little more than 200 feet vertically above the trolley track, to which the marble blocks are lowered with a cable hoist.

\section{NATURE AND SIZE OF THE OUTCROP}

On the southwest side of Yule Creek the white marble forms a continuous cliff 75 to 150 feet high and more than 4,000 feet long. To the southeast, or upstream from the quarry, the marble terminates under the angular unconformity at the base of the Jurassic (Morrison) formation; to the northwest it crosses Yule Creek and forms dip slopes that extend to the crest of Treasure Mountain. Yule Creek approximately follows the strike of the formations, and the marble thus exposed rises to the southeast with the gradient of the stream. The quarry is in the lower or downstream end of this cliff of marble (pl. 24).

The quarry has four openings or tunnels, nos. 1-4, which enter the marble cliff and cross the deposit to the hanging wall, and workings 
from them are continuous. A fifth, called nò. 5 prospect, lies a little southeast of the others. Blocks are removed by the south entrance, to no. 4 , and the men enter through no. 3. No. 1 , north of no. 3, has been closed and houses the transformer station. Nos. 2 and 3 were the source of marble before 1927 but were abandoned because blocks of adequate size free from dolomite could not be economically quarried in no. 2 and too much of the marble in no. 3 was unsound. No. 2 is now a water hole. No. 4 , which lies between no. 3 on the north and no. 2 on the south, has been the source of all the marble quarried since 1927. Its floor had a horizontal extent of 200 feet across the strike of the marble in 1936, according to Bain. ${ }^{94}$

\section{STRUCTURAL FEATURES}

Strike and dip.-The attitude of the marble is obscured by the almost complete obliteration of bedding. Unfortunately the quarry openings do not reveal clearly the true strike and dip. In the Devonian dolomite below and the Pennsylvanian shales above, a strike of N. $30^{\circ} \mathrm{W}$. was recorded with a dip of $45^{\circ}-50^{\circ} \mathrm{W}$. However, chert bands presumably parallel to bedding in the quarry strike N. $5^{\circ}-$ $10^{\circ} \mathrm{E}$. and dip about $45^{\circ} \mathrm{W}$. In the no. 5 prospect tunnel only a few hundred feet south of the quarry (see pl. 24) the chert bands strike N. $24^{\circ} \mathrm{W}$. and dip $65^{\circ} \mathrm{SW}$. In the quarry the grain of the marble is parallel to the chert bands, which in turn are believed to be parallel to the original bedding.

Thickness.-The entire Mississippian formation at the quarry is 239 feet thick, but less than half of this thickness is pure calcite marble. About 100 feet of the lower part contains interbedded dolomite marble similar to that shown in plate $3, A$, and therefore is not marketable because of its lack of uniformity both in color and in texture. It forms the footwall of the quarry. The upper 20 to 40 feet, below the overlying Pennsylvanian (Hermosa?) beds, althougb calcite marble, generally shows a few streaks of gray or red that make it unsalable. It forms the hanging wall of the quarry. There remains a thickness of 100 to 125 feet of white marble from which the salable stone is obtained. The best marble, in the recently active part of the quarry, has been obtained 50 to 75 feet below the top of the formation. The distribution of the best marble and the relation of the chert bands, fractures, veins, and grain to the bedding present a complex problem in quarrying. This problem has been given careful study by the Vermont Marble Co., as is shown in the paragraphs: below, submitted by G. W. Bain, the company's geologist, who studied. the quarry in 1936. These paragraphs confirm my observations at: the quarry and also give the results of special laboratory investigations and mill practice.

\footnotetext{
" Bain, G. W., written communication.
} 
Because of its variation in quality the deposit is divided into three parallel parts or members-the "east-side", the "bench" or central. part, and the "west-side." The width of each member varies along both strike and dip, but the aggregate thickness is remarkably. constant.

The "east-side" marble lies between the footwall and the first siliceous dolomite bed (the "east lime") within the marble horizon. It is 87 feet thick in no. 4 opening and contains some fossil corals (Syringopora and Zaphrentis) and a few brachiopods. It is dominantly light-colored and free from veining. but is locally dark blue gray along bands adiacent to the footwall and the overlying dolomite bed. It contains about $2,0<0$ grains to a square centimeter, and the grains are separated from one another by spaces 0.000007 centimeter wide. These spaces allow the marble to absorb from 0.2 to 0.3 percent of water by weight. The grains do not interlock tightly and their coefficient of irregularity (see p. 163) is $\mathbf{7 . 0 5}$. The "east-side" marble is very flexible and is considered "soft" by the quarry and mill operators. Its texture shows a much lower degree of alinement of crystal grains than that of the "westside" marble.

The low coefficient of irregularity of the "east-side" marble indicates a low degree of bonding which is not affected by - simple fabrication processes such as sand rubbing but is materially weakened by shaping in planers and turning in lathes. This feature also renders the marble unsatisfactory for steps and other forms that are subject to abrasion and other kinds of wear and lowers its resistance to weathering. The marble, however, has rendered good service as ashlar and slabs, whose surfaces are plane, sand-rubbed, or hone-finished, and it is also satisfactory for monument bases that are not subject to ap. preciable infiltration of water; but "east-side" stock is not recommended or sold by the company for monument dies.

The "bench" or middle member of the deposit lies between the two dolomite or "lime" zones, the upner of which becomes locally a zone of chert nodules. The horizontal width of the "bench" marble is 40 feet. The "bench" marble itself is white and clear, but some inconspicuous golden veining is present within the bench member. Thin cherty layers are almost completely absent, but layers of dolomite or "lime" occur at intervals of 2 to 8 feet both along and across the strike. Because of this close spacing it is difficult to obtain marble blocks more than 4 feet thick. These dolomite layers, originally continuous, have been pulled apart into lenslike or kidney-shaped masses by the flowage. that produced the marked parallel arrangement of grains in the calcite marble. Most of the dolomite masses are gray. Many were white originally but have become gray after exposure. Both varieties are brittle and have many cross fractures called "cutters" that end abruptly at the contacts between dolomite and calcite marble.

The "bench" marble contains from 2,000 to 3,000 grains to the square centimeter, with interspaces only $0.0^{\wedge} 0003$ centimeter wide. It absorbs from 0.10 to 0.13 percent of water by weight. Its grains are thoroughly interlocked, and their coeffleient of irregularity is 8.35 or more. The marble is very rigid and elastic. Permanent distortion is negligible when applied stress is held within the limits of practical use. In contrast to the "east-side" marble, no slippage along grain boundaries has been detected.

The high crefficient of irregularity of grains in the "bench" marble indicates a high degree of bonding and permits a greater variety of treatment. The marble can be carred, worked on a carborundum machine, and fabricated by most processes without raising the absorption ratio of golden vein stock abovie 
0.13 percent and that of statuary stock above 0.15 percent. It is therefore adapted to almost any use and is restricted only as regards color and available sizes of blocks.

The "west-side" marble member is the choice part of the deposit. It lies between the cherty upper dolomite zone and the cherty layers adjacent to the hanging-wall conglomerate. Its thickness varies slightly from an average of 75 feet. It contains zones of light, golden-vein, and white statuary marble separated by thin cherty beds and rows of nodular chert. These zones rarely attain 10 feet in horizontal width, and blocks more than 8 feet in their smallest dimension and free from chert are difficult to obtain. Large masses of dolomite or "lime", however, are absent. The marble itself is extremely white and clear, and its grains have a distinctly linear pattern.

The "west-side" marble contains from 2,000 to 3,000 grains to the square centimeter. The grains are slightly smaller and irregular adjacent to goldenrein and chert bands than elsewhere. Tests show an extremely low ratio of absorption. Twenty different cubes of statuary grade absorbed less than 0.12 percent of water by weight, and cubes of golden-vein grade absorbed 0.10 percent or less. Spaces between grains in the golden-vein parts average 0.0000025 centimeter in width and those in the statuary parts average 0.003003 . The coefficient of irregularity is over 10 in the golden-vein parts and over 9 in the statuary parts. The marble is extremely rigid, and in its modulus of elasticity it ranks with the marbles of highest grade. The linear arrangement of the crystal grains is very distinct, and 10 percent of their vertical axes fall within 1 percent of the area of a projection sphere.

The high degree of irregularity of grains in the "west-side" marble adapts it to the greatest variety of uses. Because of its greater thickness and its uniform markings and quality the sizes of its blocks are not so restricted as those of the "bench" marble. The extreme degree of linear crystal arrangement renders the "west-side" marble unusually translucent, and it is one of the company's chief sources of "lumar"-marble in thin slabs lighted from behind.

Fractures.-Two sets of fractures are recognized, and both are important in quarrying the marble. A third set is confined to marble within 10 or 15 feet of the surface and therefore of no great consequence. The first two sets are classed as "main headers" and "dry seams" by quarrymen. The main headers are readily visible in the quarry and are comparatively continuous. They strike abn+* N. $65^{\circ}$ E., dip $80^{\circ} \mathrm{S}$., and lie from 30 to 50 feet apart. The dry seams are inconspicuous and not continuous. They strike N. $55^{\circ}$ W. and dip $65^{\circ}-75^{\circ} \mathrm{NE}$. They occur in steplike (en échelon) zones that are more irregularly spaced but closer together than the main headers and not easily seen. They are, therefore, a constant obstacle to quarrying. Not infrequently a large block of marble channeled and broken loose at considerable expense will split into two pieces along a dry seam. It even happens that these flaws do not show up until after a block has been cut into slabs in the mill.

The features described are represented in figure 23, a diagrammatic representation of conditions observed in opening 3 , but the zones of dry seams are inadequately represented, so as to avoid overcrowding the diagram. It is, of course, desirable to quarry rectangular blocks. Furthermore, for "golden vein" marble, it is necessary that the blocks 
be oriented properly with bedding. With the sets of fracture nearly at right angles to each other and at an angle to the bedding, such rectangular blocks are difficult to obtain. To obtain the largest blocks the marble is quarried with the bedding in places where the fractures are least pronounced; but near the larger fractures or main headers the cuts are made at different angles, depending on the prevalence of the smaller fractures or dry seams, chert bands, masses

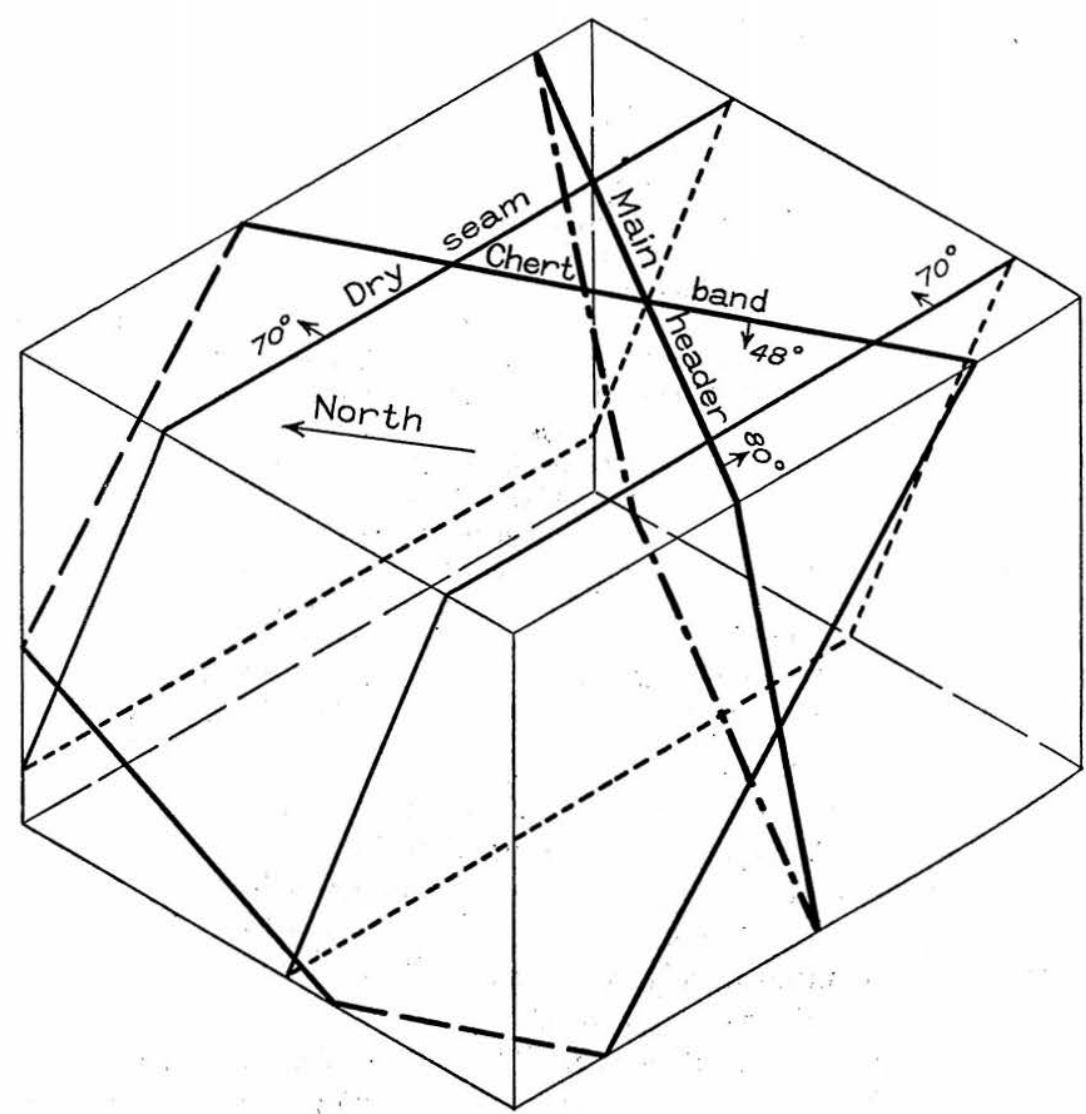

FIGURE 23.-Block diagram showing relation of the joint systems, chert bands, and dolomitic bodies found in the quarry. "Grain" or schistosity is parallel to chert bands.

of dolomite, and diopside-quartz lenses. Quarrying with or across the bedding is also governed by the grade of stock to be produced, as shown on pages 170,171 .

In spite of these difficulties the quarry can produce large blocks of essentially pure-white marble. Dimensions noted by Merrill ranged from 6 to 23 feet in length, 3.3 to 8 feet in width, and 2 to 4.7 feet in thickness. 


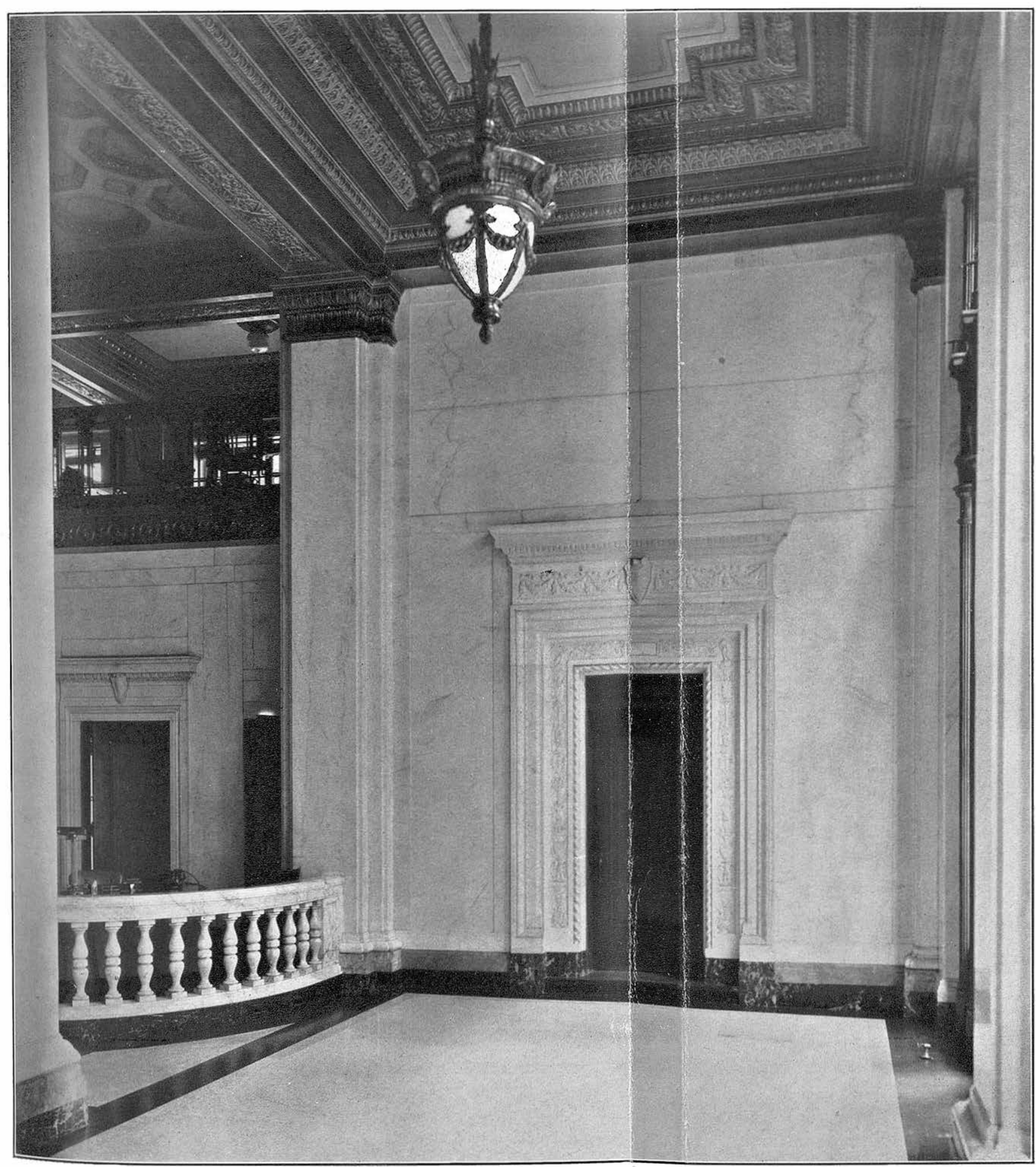

"YULE VEINED STATUARY" (SECOND STATUARY) WALK AND TRIM, WITH ITALIAN "BLACK AND GOLD" BASE. Fidelity Building, Los Angeles, Calif. Courtesy of the Vermont Marble Co. 


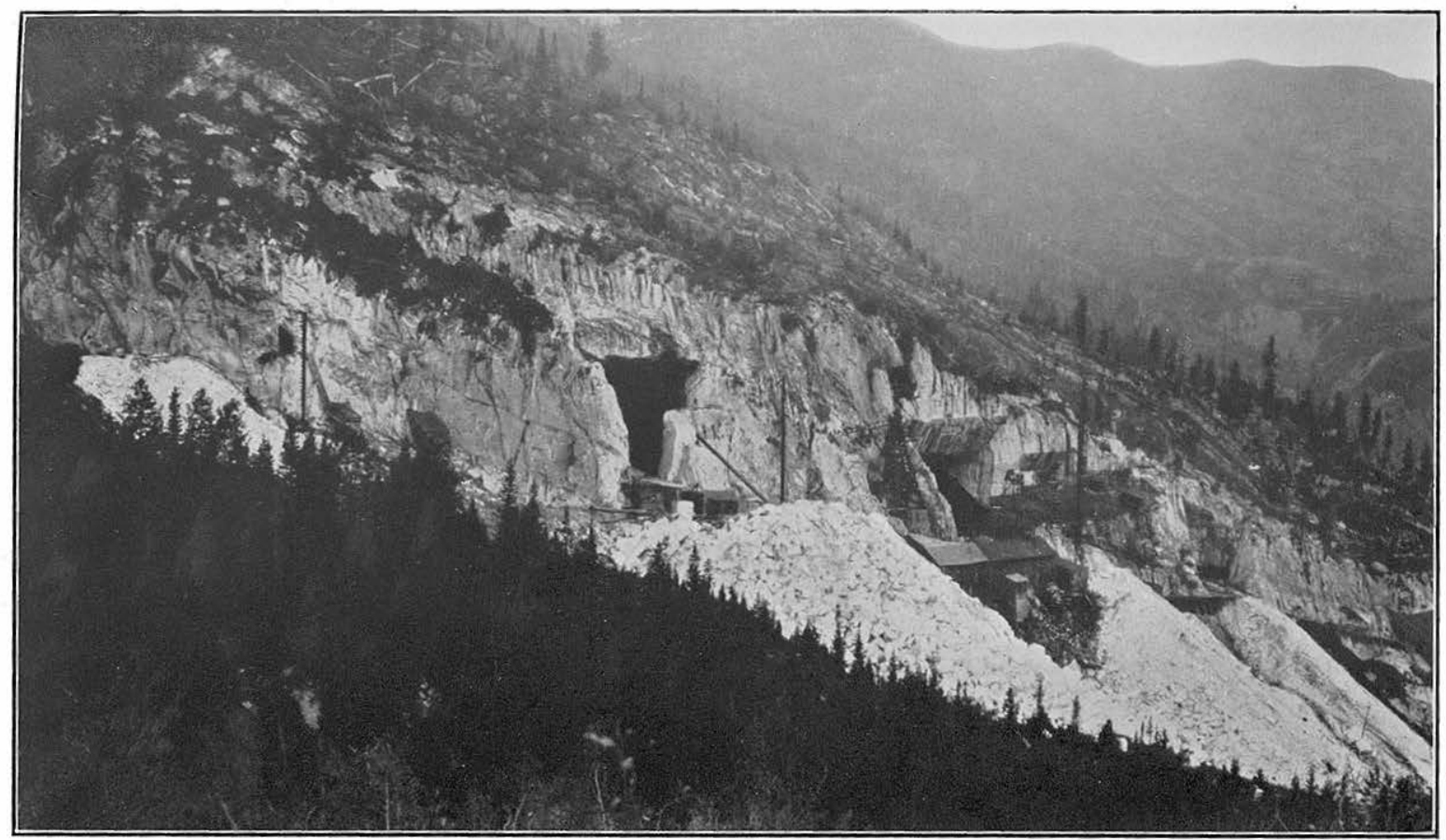

CLIFF OF WHITE MARBLE SHOWING POSITION OF YULE COLORADO MARBLE QUARRY. The white dump at the left is from a prospect. 
The largest block quarried, that for the Tomb of the Unknown Soldier in Arlington National Cemetery, Va., measured 14.0 by 7.4 by 6.0 feet and in the rough weighed 56 tons. The method of quarrying and shipping this block, as described in a written communication by H. S. Hobart, who was then in charge of the quarry, and in a published article, ${ }^{95}$ is summarized as follows:

To obtain a block of desired quality for the die of the monument required more than a year. It was first necessary to quarry a mass that weighed. more than 100 tons. A wire saw was then installed in the quarry to cut it approximately to the size required and to reduce its weight to an amount that could be safely handled with the equipment available and also to detect any defects. The block thus reduced weighed 56 tons. It was hoisted from the quarry by a specially reinforced derrick shipped from Vermont for the purpose. Before hoisting, the block was allowed to hang in the ropes for about 15 minutes to test their strength. The straight lift from the floor to the top or quarry bank was about 100 feet. Upon reaching the top the block was swung about $90^{\circ}$ and landed on a "home-made" car which had two low wheels in front and none in back, the rear end dropping to assist in braking. the load. It was then moved for about 200 feet along a track that had approximately a $20^{\circ}$ grade and a $20^{\circ}$ curve where it passed out of the quarry opening. As the block was much too heavy for the 800 -foot cableway from the quarry to the trolley line, it was necessary to build a track 600 feet long up the slope to connect with the 200-foot track leading from the quarry. As the trolley line to Marble had a minimum grade of 4 percent and grades of 10, 12, and even 17 percent at certain places, a regular block car could not be used, especially as the block had to be moved in January, when it would have been too cold to brake so heavy a load. The temporary track, therefore, was connected with the trolley track and the "home-made" car made the trip of $3 \frac{1}{2}$ miles to Marble in 2 days. Two electric locomotives, one before and one behind the car, did the hauling. As the concentrated load on the "home-made" car could not cross the bridge over the Crystal River safely, a regufar railroad flat car on which the block was to be shipped was pushed across the bridge, the trolley track disconnected and raised to the top of the flat car, and the marble block hauled onto the flat car with tackle blocks. The block was then shipped to West Rutland, Vt., for sawing, thence to Proctor, Vt., for cutting, and finally to Arlington Cemetery, Va., for erection and carving.

\section{GRADES OF MARBLE}

In outcrop the marble is of very uniform appearance. Cut and polished surfaces, however, show combinations of clear massive white stone, delicate brown streaks loeally termed "veins", and chert fragments. Irrespective of strength and durability, therefore, there are differences of attractiveness which, although largely a matter of personal preference, are sufficiently marked to affect the market price. These differences together with adaptability for different uses form

${ }^{95}$ A block of marble for the Unknown Soldier's tomb: Through the Ages, vol. 9, no. 3, Dp. $24-28,1931$.

$131028-37-12$ 
the basis for grading. The marble is grouped by the company ${ }^{96}$ into the four grades cited below. A fifth grade, called "crystal", was marketed until 1936, when its sale was discontinued.

1. Statuary marble.-The most valuable grade. Essentially pure white, with less than 0.1 percent of golden or other veining. Its grain size and the color of its surfaces are as nearly uniform throughout as can be selected by experienced graders.

2. Veined or second statuary marble.-Similar to grade 1 but may have as much as 0.5 percent of veining or clouding. (See pl. 23.) The texture is usually very uniform, and markings are so spaced as to be inconspicuous. Usually only marble graders can distinguish between statuary and veined statuary.

3. Golden-vein marble.-White with pronounced veining. The veins are delicate brown to yellowish streaks that average less than a quarter of an inch in thickness and extend more or less regularly across even large slabs. Slight variation in grain size adjacent to the veins may be evident but is essentially a microscopic feature. The presence of a few gray streaks and minute quantities of chert may be tolerated. This grade, represented in plates 21 and 22 , is the dominant product of the quarry.

4. Bottom-base stock. - Similar to the golden-vein marble but with small irregularities in marking that give one face of a block a different appearance from the others. This face may be used as the bottom in a monument, pillar drum, or similar block, so that it appears identical with the golden-vein marble; but this restriction in its use reduces it below the regular golden-vein grade.

5. Crystal grade.-The crystal grade, discarded in 1936, was similar to the golden-vein and statuary grades but contained an appreciable quantity of chert, mostly in thin streaks. The gray color commonly associated with the chert is also conspicuous. The discarding of this grade resulted from the company's country-wide study of buildings containing Yule Colorado marble, which showed that the chert aged to a dark-gray color and that the cherty marble did not have as satisfactory an appearance as the other grades. Much of the marble in the Lincoln Memorial, which evidently represents quarry-run material, is of the "crystal" grade. Several blocks in this memorial and in the Denver post office contain fractures or "dry seams" and reflect the difficulty that the original operators had in obtaining marble absolutely free from flaws from no. 3 opening.

The foregoing grades include marble for all uses, with due regard to the surfaces that are to be exposed. A slab for the wall of a building, for example, may qualify as of statuary grade although it was sawed from a block that as a whole would have to be classed in a different grade. Slabs or blocks selected from bottom-base stock may pass for either statuary or golden-vein grade, so long as any disqualifying markings are confined to concealed surfaces.

Veining or marking, though irregular, is commonly subparallel to the bedding. Most of the statuary marble is sawed parallel to the bedding, but most of the golden-vein marble is quarried and sawed in a vertical plane to give a diagonal pattern, and stock thus ob-

Information furnished by H. S. Hobart and G. W. Bain; of the Vermont Marble Co. 
tained is called "diagonal golden vein." Some blocks are sawed in a horizontal plane or parallel to the quarry floor to produce an irregular, interfingering pattern, and stock from them is called "top-of-the-quarry golden-vein." Golden-vein stock sawed parallel to the bedding is also furnished but is not popular.

Antiquing or aging.-The marble eventually acquires a light creamy tone or "patina", which is much sought by sculptors. The time required for this tone to develop on "west-side" and "bench" stock is influenced by the kind of finish given. With the roughsand finish, which is used on all building stock unless otherwise specified, the creamy tone becomes evident in about 15 years unless its development is artificially hastened; with the fine-sand finish and honed surfaces more than 20 years is required for the same degree of tone to appear. The statuary grades show the creamy tone somewhat sooner than the golden-vein grade. Polished slabs of "west-side" marble have lain beside the railroad at Marble for 20 years without any change in color or dulling of the surface.

RESERVES OF MARBLE

The depth to which the marble can be expected has not been determined, but along the outcrop from the crest of Treasure Mountain down to Yule Creek through a vertical distance of about 2,000 feet no distinct difference in the degree of marbleization has been noted. The extent down the dip, therefore, is probably greater than the depth to which quarrying is commercially feasible.

The pits from which the marble has been quarried are only about 200 feet deep and still about 50 feet above the level of the track. By crosscutting from the track level to the marble an additional depth equal to that quarried will be made available. The three pits in their combined length expose fully 600 feet of the bed along the strike. Marble of uniform character is present throughout this distance and probably continues an equal distance to the south, where the bed has not been developed. On this basis, which is believed to be conservative, the marble reserve of this quarry is three times greater in volume than that already quarried. 
REPRESENTATIVE BUILDINGS CONTAINING YULE COLORADO MARBLE

The buildings listed below illustrate the different interior and exterior uses of Yule Colorado marble:

\section{Representative buildings containing Yule Colorado marble}

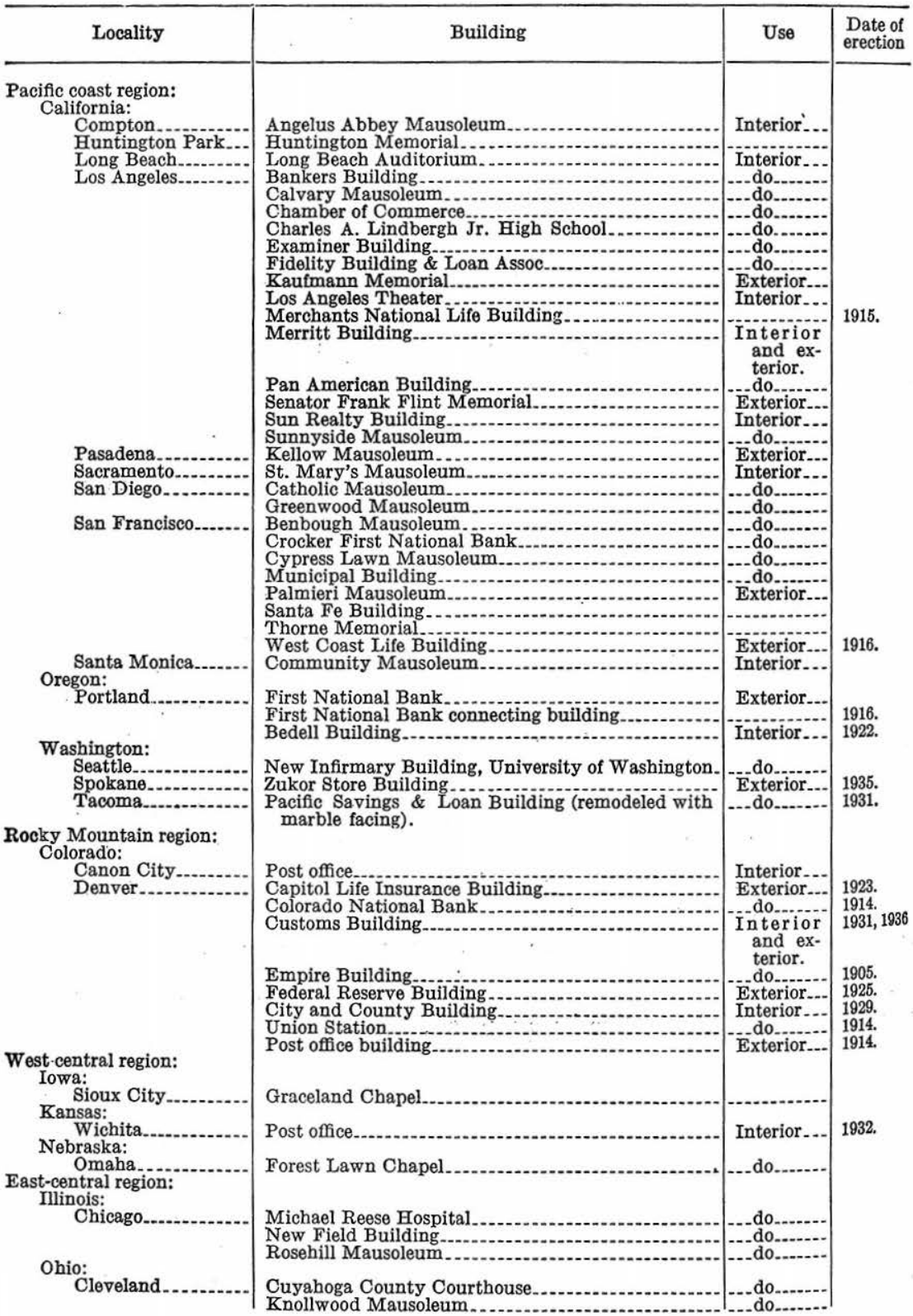


Representative buildings containing Yule Colorado marble-Continued

\begin{tabular}{|c|c|c|c|}
\hline Locality & Building & Use & $\begin{array}{l}\text { Date of } \\
\text { erection }\end{array}$ \\
\hline 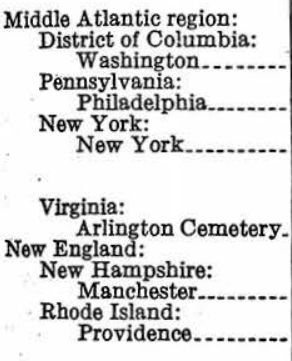 & $\begin{array}{l}\text { Lincoln Memorial } \\
\text { Byberry Hospital } \\
\text { Fidelity Bond \& Mortgage Co } \\
\text { Goelet Building (entrance) } \\
\text { Municipal Building } \\
\text { Tomb of Unknown Soldier. } \\
\text { Elliott Memorial. } \\
\text { Providence County Courthouse }\end{array}$ & Interior... & 1915. \\
\hline
\end{tabular}

OTHER MARBLE DEPOSITS

Each sedimentary formation has formed a particular kind of marble, depending on its composition, and a great variety is therefore present in the area. These varieties are mentioned in the early descriptions of the marble, and, although the Mississippian limestone alone has been quarried, the other varieties present in Ordovician, Devonian, and Pennsylvanian formations are still referred to occasionally as of possible commercial value. For this reason the properties pertaining to marketability of the marble of each formation are briefly given below. Detailed metamorphic effects are described elsewhere in this report.

\section{ORDOVICIAN}

The Ordovician contains serpentine marble (Manitou dolomite) and white marble (Fremont limestone). The white marble of the Fremont is a single massive bed 30 to 40 feet thick. It is a mediumgrained rock very similar lithologically to the Yule Colorado marble. No attempts have been made to quarry this bed, for although apparently of good quality it is not as thick a bed as the white marble of the Mississippian limestone and it is less favorably located.

Bedding planes are very prominent in the serpentine marble and commonly limit the thickness of quarry blocks to about 2 feet, although a few are 4 feet thick. The marble contains countless irregular and wavy stringers of gray or green to yellow serpentine parallel to the bedding. (See pl. 11, A.) Commonly a gradation from greenish yellow through green to black occurs in an individual band. The calcite groundmass is white to gray and provides an attractive contrast to the colors of the serpentine.

A small amount of serpentine marble was quarried at the head of Yule Creek, but so far as is known not any was marketed. More favorable locations of similar serpentine marble are opposite or southeast of the quarry of the Yule Colorado Marble Co. on Yule 
Creek and a short distance south of Twin Bridges on the Crystal River. Should the quality of this rock ever warrant the expense of prospecting, the beds could be tested at each place with the use of diamond drills.

\section{DEVONIAN}

Dolomite of the Devonian recrystallized to a fine-grained marble of light buff to gray. The bedding planes are well developed and spaced less than 2 feet apart. In many places white diopside is present. The diopside as a rule is evident only on weathered surfaces and may be so small in amount that it can be detected only by very careful examination under the microscope, or by dissolving out the calcite with acid. Both the color and relative thinness render this bed unmarketable. .

\section{PENNSYLVANIAN}

Much marble occurs in the Pennsylvanian Hermosa (?) formation, but as a rule it is gray and unattractive. Most of the beds are thin as well as impure and interbedded with either sandstone or shale. Locally specimens of black marble are available, and these have attracted some attention. However, the black marble is too slight in extent and too irregular in occurrence to be of commercial value.

One bed of limestone in the Hermosa (?) formation resembles the white marble of the Mississippian as seen from a distance. Conspicuous exposures of this bed are to be seen on the slope of Crystal Mountain both in North Pole Basin and Bear Basin, on the northwest face of Treasury Mountain in the extreme head of Bear Basin, and on the east and north slope of Whitehouse Mountain. On the slope of Crystal Mountain the color of the white marble, which is a recrystallized limestone conglomerate (pl. 4, A), is not uniform and is unattractive. In the second locality referred to, the marble is 20 to 30 feet thick, and it appears white from a distance, but at close range it has a decided yellow cast due to the presence of much serpentine. The color is uniform and rather attractive, but the bed occurs only on the east side of Bear Basin, where it is virtually inaccessible. The Pennsylvanian marble on Whitehouse Mountain is of considerable thickness but is too thin-bedded to be of commercial value; in addition its color is not a uniform white but is shaded with strong tints of buff and gray. It is a recrystallized magnesian or dolomitic limestone, and the irregular distribution of the dolomite accounts for the lack of uniformity in color. No effort has been made to develop any of the Pennsylvanian marble. 


\section{PATENTED CLAIMS}

The following table lists the patented claims shown on the map (pl. 1, oversheet) in numerical and alphabetic order and gives the patent numbers.

Index of claims shown on map ( $p l .1)$ in numerical order

\begin{tabular}{|c|c|c|c|c|c|}
\hline $\begin{array}{l}\text { No. } \\
\text { on } \\
\text { map }\end{array}$ & Name of claim & Patent no. & $\begin{array}{l}\text { No. } \\
\text { on } \\
\text { map }\end{array}$ & Name of claim & Patent no. \\
\hline 1 & Schofield Placer & 8260 & 80 & Victoria..... & \\
\hline 2 & Stonington Town Site & 8000 & 83 & City of Rome. & 8601 \\
\hline 3 & Marble City Placer. & $7741 \mathrm{Am}$ & 84 & Charlotte..... & 8601 \\
\hline 4 & Williams No. 1 . & $6360 \mathrm{~A}$ & 85 & Royal Arch.. & 8601 \\
\hline 5 & Williams No. 2 & $6360 \mathrm{~A}$ & 86 & Minnie Frien & 10060 \\
\hline 6 & M. S $\ldots$ & $6166 \mathrm{~B}$ & 87 & Grand Ella.- & 10060 \\
\hline 7 & Banner Place & 7602 & 88 & Sweepstakes. & 6645 \\
\hline 8 & Baniner M: S & $6250 \mathrm{~B}$ & 89 & Dora............ & 6645 \\
\hline 9 & Evans..... & 6410 & 90 & Wedge..... & 10060 \\
\hline 10 & Keystone N & 5361A & 93 & Condon.... & 6645 \\
\hline 11 & Wooden Eagle M & $6361 \mathrm{~B}$ & 94 & Nellie $\mathrm{R}$ & 6645 \\
\hline 12 & Lakelet M. S.... & $6360 \mathrm{~B}$ & 95 & Ida B & 6645 \\
\hline 13 & Guilford... & 6361A & 96 & Lillian. & 6645 \\
\hline 14 & Lacy Place & 8260 & 97 & Lottie. & 6645 \\
\hline 15 & Virginia... & 12206 & 98 & Howard..... & 6645 \\
\hline 16 & Greensboro & 12204 & 99 & White World & 6645 \\
\hline 17 & Valley & 3388 & 100 & Red Plume.. & 6645 \\
\hline 18 & H. E. S. No. 318 (H. G. Haxby) & & 101 & Sally $\mathrm{K}$ & 6645 \\
\hline 19 & Queen Place & 7738 & 103 & Lead Chief. & 6939 \\
\hline 20 & City of Gla & 3387 & 104 & Eagle......... & 5587 \\
\hline 21 & Lady Gay & 3521 & 105 & Bonanza Kin & 6463 \\
\hline 23 & Overland No. 2 & 7955 & 106 & Giblets & 6645 \\
\hline 24 & Georgia & 6238 & 107 & Serpentine M & 20117 \\
\hline 25 & Tennessee. & 6238 & 108 & Extension & 13293 \\
\hline 26 & Monitor Pla & 8543 & 109 & Extension $\mathrm{No}$ & 13293 \\
\hline 27 & Vermont Pla & 8543 & 113 & 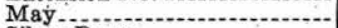 & 8487 \\
\hline 28 & Marble Pla & 8543 & 114 & Silver Purse. & 6675 \\
\hline 29 & Prince of Wales & $6250 \mathrm{~A}$ & 115 & Orphan Boy. & 6769 \\
\hline 30 & The Black Marble Placer. & 12228 & 116 & Silver Nugget & 6676 \\
\hline 33 & R. H. K. & $6166 \mathrm{~A} \mathrm{Am}$ & 117 & Lizzie G. \o. & 6408 \\
\hline 34 & Yule Placer. & 3618 & 118 & Stanley No. 2 & 7318 \\
\hline 35 & Star & 6674 & 119 & Stanley No. 1. & 7318 \\
\hline 36 & Banner & $6339 \mathrm{~A}$ & 120 & Silvery Crop. & 6471 \\
\hline 37. & Eagle... & $6339 \mathrm{~A}$ & 123 & Spar & 6471 \\
\hline 38 & Falcon. & $6339 \mathrm{~A}$ & 124 & Brooklyn.... & 647 \\
\hline 39 & Flag & $6339 \mathrm{~A}$ & 125 & Silver Ćrown & 6471 \\
\hline 40 & Curbstone. & $6339 \mathrm{~A}$ & 126 & Ben Hur......... & 6471 \\
\hline 43 & Flag M. S & $6339 \mathrm{~B}$ & 127 & Crystal River & 6471 \\
\hline 44 & Corwen Place & 17727 & 128 & Catalpa..... & 7027 \\
\hline 45 & Blue Marble & 4411 & 129 & Handy & 6471 \\
\hline 46 & White Marble & 4411 & 130 & King Solomor & 6471 \\
\hline 47 & London.... & 4411 & 133 & May Flower I & 6471 \\
\hline 48 & New Discov & 4411 & 134 & May Flower & 6471 \\
\hline 49 & Yule.... & 4530 & 135 & Rascal Marbl & 19244 \\
\hline 50 & Prince Arthu & 4530 & 138 & Silver King- & .8064 \\
\hline 53 & Italian.... & 4530 & 139 & Tennessee... & 6471 \\
\hline 54 & Empress. & 4530 & 140 & Silver Tip.-- & 806 \\
\hline 55 & Emperor. & 4530 & 143 & Lyons. & 6471 \\
\hline 56 & Dolomite. & $=4530$ & 144 & Sorrel Bronch & 6471 \\
\hline 57 & Hogback. . & 4474 & 145 & Blue River. & 6471 \\
\hline 58 & Vermont. - & 4474 & 146 & Luck y Star... & 6471 \\
\hline 59 & White Lime & 5113 & 147 & Copper King. & 686 \\
\hline 60 & Turbine. & $6339 \mathrm{~A}$ & 148 & Leviathan.-.. & 4127 \\
\hline 61 & Fraction. & 4474 & 149 & General Stone & 6787 \\
\hline 62 & Lake..... & 8601 & 150 & Watcoga......... & 6329 \\
\hline 63 & Islet Place & 8680 & 151 & Black Eagle. & 6329 \\
\hline 64 & Kline Pla & 8680 & 152 & Hawley ......... & 15073 \\
\hline 65 & Raspberr & 4474 & 153 & Black Bird... & 6329 \\
\hline 66 & Belloy & 4474 & 154 & Little Anna.. & 6329 \\
\hline 67 & Hoos & 4474 & 155 & Little Doris - - & 15073 \\
\hline 68 & (2) & 6431 & 156 & Silver Tip No & 806 \\
\hline $\begin{array}{l}69 \\
70\end{array}$ & 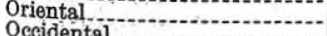 & 6431 & 157 & Island Belle.-. & 6833 \\
\hline 71 & (1) & 4474 & 158 & MeVey Placer & 15072 \\
\hline 72 & 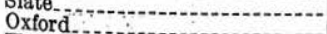 & $\begin{array}{l}4474 \\
8601\end{array}$ & $\begin{array}{l}159 \\
160\end{array}$ & J. T. Johnston. & 765 \\
\hline 73 & Hood Placer. & 8601,19217 & 163 & $\begin{array}{l}\text { Pat Moore.... } \\
\text { Daisy }\end{array}$ & $\begin{array}{l}7655 \\
7655\end{array}$ \\
\hline 74 & White Cloud & 8601 & $\begin{array}{l}100 \\
164\end{array}$ & McKee................... & 15073 \\
\hline 75 & Albatross & 8601 & 165 & Legacy......... & 7655 \\
\hline 76 & Fine Marble & 16451 & 166 & Black Queen & 5783 \\
\hline 77 & Pilot Knob & 8601 & 167 & Mountain Chief. & 3458 \\
\hline 79 & Marble Herd..... & 8601 & 168 & General Geo. A. Sto & 4043 \\
\hline & 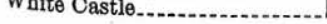 & 8601 & 169 & New York City & 6807 \\
\hline
\end{tabular}


Index of claims shown on map ( $p l .1)$ in numerical order-Continued

\begin{tabular}{|c|c|c|c|c|c|}
\hline $\begin{array}{l}\text { No. } \\
\text { on } \\
\text { map }\end{array}$ & Name of claim & Patent no. & $\begin{array}{l}\text { No. } \\
\text { on } \\
\text { map }\end{array}$ & Name of claim & Patent no. \\
\hline 170 & Geo. A. Dur & 4044 & 270 & Bear Mounta & 13621 \\
\hline 173 & Excelsior No. & 4302 & 273 & Bear Moun & 13621 \\
\hline 174 & Small Hopes. & 6654 & 274 & Bear Mount & 13621 \\
\hline 175 & Mountain Lio & 3637 & 275 & Bear Mountain No. 22 & 13621 \\
\hline 176 & Goođenough. & 18880 & 276 & Bear Mountaín No. 21. & 13621 \\
\hline 177 & Kershaw.... & $8641 \mathrm{~A}$ & 277 & Bear Mountain No. 20 & 13621 \\
\hline 178 & Cleopatra & $4187 \mathrm{~A}$ & 278 & Bear Mountain No & 13621 \\
\hline 179 & Gothic Belle & 3872 & 279 & Bear Mountain No & 13621 \\
\hline 180 & Undine & 8641 & 283 & Bear Mountain No. & 13621 \\
\hline 183 & Undine No. & 8641 & 281 & Bear Mountain No. & 13621 \\
\hline 184 & Mammoth & $4186 \mathrm{~A}$ & 285 & Bear Mountain No. & 13621 \\
\hline 185 & Monarch... & 18290 & 286 & Bear Mountai & 13621 \\
\hline 186 & Big Indian. & 4068 & 287 & Bear Mountair & 13621 \\
\hline 187 & Scottish Chi & 3864 & 288 & Crystal Mounta & 19862 \\
\hline 188 & Dalton......... & 4189 & 289 & Crystal Mou & 19862 \\
\hline 189 & Truckie.:- & 4188 & 290 & Crystal Mov & 19862 \\
\hline 190 & Climax & 7739 & 293 & Monte Crist & 19862 \\
\hline 193 & Margaret D. & 15242 & 294 & Monte Cristc & 19862 \\
\hline 194 & Bruin & 4066 & 295 & Harris and Farley. & 777 \\
\hline 195 & Silver Bell. & 4067 & 296 & Schofleld. & 4360 \\
\hline 196 & Homestake $\mathrm{N}$ & 3772 & 297 & Riverside No. 1. & 8633 \\
\hline 197 & Milwaukee_... & 2922 & 298 & Aspen No. 1.... & 8633 \\
\hline 198 & Rocky Point. & 16595 & 299 & Crystal Mountain No. & 19862 \\
\hline 199 & Homestak $\theta$ & 2857 & 300 & Aspen & 8633 \\
\hline 200 & City Detroit. & 8641 & 303 & Riverside.... & 8633 \\
\hline 202 & Banker's Daughter & 8627. & 304 & Bear Mountai & 13621 \\
\hline 203 & Belle of Mexi & 5593 & 305 & Bear Mount: & 13621 \\
\hline 204 & Evening Sta & 3456 & 306 & Bear Mou & 13621 \\
\hline 205 & J. A. Garfiel & 18806 & - 307 & Bear Mou & 13621 \\
\hline 206 & Fargo_. & 5538 & 308 & Bear Mou & 13621 \\
\hline 207 & Saturday Nig & 7655 & 309 & Bear Mou & 13621 \\
\hline 208 & Dynamite. & 7655 & 310 & Bear Mou & 13621 \\
\hline 209 & San Diego. & 3793 & 311 & Bear Moun & 13621 \\
\hline 210 & 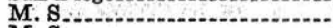 & $4187 \mathrm{~B}$ & 313 & City........... & 7849 \\
\hline 211 & M. S. & $4186 \mathrm{~B}$ & 314 & Wanderer .- & 7849 \\
\hline 213 & Lucky Boy.. & 2858 & 315 & Protection. & 7085 \\
\hline 214 & Stonewall... & 6123 & 316 & Home...... & 7085 \\
\hline 215 & Sweet Home & 3457 & 317 & M. $\mathrm{S}$ & $5309 \mathrm{~B}$ \\
\hline 216 & Diadems:-. & 12166 & 318 & Lost Horse M & $6239 \mathrm{~B}$ \\
\hline 217 & Mora-Cam & 3793 & 319 & O. B. B & 8581 \\
\hline 218 & Silver Temp & 7117 & 320 & Inez No.4.- & 11450 \\
\hline 219 & Look Out_- & 16596 & 321 & Inez No. 3... & 11450 \\
\hline 220 & Ute Chief & 3000 & 322 & Inez No. 2 & 11450 \\
\hline 223 & Lake Superic & 3001 & 323 & Crystal M. S & $5708 \mathrm{~B}$ \\
\hline 224 & Romance & 3635 & 324 & Gray Copper.- & $5309 \mathrm{~A}$ \\
\hline 225 & Brittle Silve & 3636 & 325 & Inez No. 1 & 11450 \\
\hline 226 & Bald Eagle. & 3545 & 326 & Havelock No. 1. & 18606 \\
\hline 227 & Frank Howar & 3199 & 327 & Havelock & 18606 \\
\hline 228 & America. & 7863 & 328 & er King N & 18606 \\
\hline 229 & Iron Clad & 7863 & 329 & Copner King No & 18606 \\
\hline $230^{r}$ & Black Hawk: & 7863 & 330 & Copper King No & 18606 \\
\hline 233 & Spar & 7863 & 333 & Copper King No & 18606 \\
\hline 234 & Atlanta. & 7863 & 334 & Copper $\overline{\mathrm{Ki}}$ & 18606 \\
\hline 235 & Michigan & $6239 \mathrm{~A}$ & 335 & Copper King & 18606 \\
\hline 236 & Lost Horse. & $6239 \mathrm{~A}$ & 336 & Lead Chiel.... & 2548 \\
\hline 237 & Carlyle & 2671 & $33 \pi$ & 20th Century & 18906 \\
\hline 238 & Clarke No. 3 & 3136 & 338 & 20 th Ce & 18606 \\
\hline 239 & Clarke No. 2. & 3198 & 339 & Copp & 18606 \\
\hline 240 & Inez No. 13 & 11450 & 340 & Copper $\mathbf{K} i n g$-. & 18606 \\
\hline 243 & Inez No. 12. & 11450 & 341 & 20th Century N & 18606 \\
\hline 244 & Inez No. 11. & 11450 & 343 & Copper Ki & 18606 \\
\hline 245 & Inez No. 10. & 11450 & 344 & Copper $\mathrm{K}$ in & 18606 \\
\hline 246 & Inez No. 9 & 11450 & 345 & Copper King $\mathrm{N}$ & 18606 \\
\hline 247 & Inez No. 8 . & 11450 & 346 & Copper King $\mathrm{N}$ & 18606 \\
\hline 248 & Inez No.7. & 11450 & 347 & Copper $\mathrm{K}$ in & 18606 \\
\hline 249 & Inez No. 6:- & 11450 & 348 & Winchestor.-. & 18600 \\
\hline 250 & Inez No. 5 . & 11450 & 349 & Winchester No. 1 . & 18606 \\
\hline 253 & Pointer...... & 11450 & 350 & ester No. 2.. & 18600 \\
\hline 254 & Midland. & 5315 & 353 & El Negocio........... & $\begin{array}{r}15329 \\
183\end{array}$ \\
\hline 255 & Intern & 12098 & 354 & Irene. & 4185 \\
\hline 256 & Bullion Queen & 12098 & 355 & Eaton.... & \\
\hline 257 & Crystal City No. 3. & 8581 & 356 & Denver City......... & 9929 \\
\hline 258 & Crystal City & 8581 & 357 & Mammoth Cave............ & $\begin{array}{r}9929 \\
10280\end{array}$ \\
\hline 259 & Crystal City No: $2 \ldots$ & 8581 & 358. & Daisy $: \ldots . . . .$. & 10230 \\
\hline 260 & Tiger.......... & 8581 & 359 & Agatha............ & $\begin{array}{r}10280 \\
7950\end{array}$ \\
\hline 263 & Cashier & 8581 & 360 & Buckeye Boy & 7950 \\
\hline 264 & Old Solitary & 12808 & 361 & Buckeye No. 1 . & 18707 \\
\hline 265 & Bear Mountain No. 1... & 13621 & 36 & McPike & 13442 \\
\hline 266 & Bear Mountain No. 2 & 13621 & 36 & King Solomon & $3717 \mathrm{Am}$ \\
\hline $\begin{array}{l}267 \\
268\end{array}$ & Bear Mountain No, 3...... & 13621 & 364 & El Dorado & 7950 \\
\hline 269 & $\begin{array}{l}\text { Bear Mountain No. } 4 \\
\text { Bear Mountain No. } 5 \text {. }\end{array}$ & $\begin{array}{l}13621 \\
13621\end{array}$ & $\begin{array}{l}365 \\
366\end{array}$ & Smuggler..... & 10280 \\
\hline
\end{tabular}


Index of claims shown on map (pl. 1) in numerical order-Continued

\begin{tabular}{|c|c|c|c|c|c|}
\hline $\begin{array}{l}\text { No: } \\
\text { on } \\
\text { map: }\end{array}$ & Name of claim & Patent no. & $\begin{array}{l}\text { No. } \\
\text { on } \\
\text { map }\end{array}$ & Name of claim & Patent no. \\
\hline 367 & Power............. & 19655 & 468 & Shakespeare No. 2. & 16164 \\
\hline 368 & Mary Newcomb $\mathrm{M}$ & 5946B & 469 & Shakespeare No. 1 . & 16164 \\
\hline 369 & Lead King M. S... & $11587 \mathrm{~B}$ & 470 & Clipper & 4857 \\
\hline 370 & Mary Newcomb.. & $5946 \bar{A}$ & 473 & North Pole No. 7 . & 16164 \\
\hline 373 & Ben Butler No. 4. & 5707 & 474 & North Pole No. 8 & 16164 \\
\hline 374 & Lead King ......... & $11587 \mathrm{~A}$ & 475 & North Pole No. & 16164 \\
\hline 375 & F. G. Richardson. & $5710 \mathrm{~A}$ & 476 & North Pole No. 10 & 16164 \\
\hline 376 & Laura............... & 2547 & 477 & North Pole No. 11 & 16164 \\
\hline 378 & Meadow Mountain No. 3 & 18679 & 478 & North Pole No. 14 & 16164 \\
\hline 379 & Meadow Mountain No. 2 & 18679 & 479 & North Pole & 16164 \\
\hline 380 & Meadow Mountai & 18679 & 480 & North Pole I & 16164 \\
\hline 383 & Graham & 16366 & 483 & North Pole No. & 16164 \\
\hline 384 & F. G. Richardson & $5710 \mathrm{~B}$ & 484 & Puritan No. 9 & 20325 \\
\hline 385 & Prospect............ & 4160 & 485 & Mammoth No. 3 . & 3617 \\
\hline 386 & Belleview & 5709 & 486 & Puritan No. 10 & 20325 \\
\hline 387 & John M. Maxwell. & $5708 \mathrm{~A}$ & 487 & Puritan No. 11 & 20325 \\
\hline 388 & Extension.................... & 9929 & 488 & Greenback & 3441 \\
\hline 389 & Burt & 12588 & 489 & Mammoth N & 3616 \\
\hline 390 & Bellex of the West. & 3773 & 490 & Puritan No. 8 & 20325 \\
\hline 391 & New York & 16360 & 493 & Puritan No. 7 & 20325 \\
\hline 393 & Belle of Titusville M. S. & 9697 & 494 & Iron & 2815 \\
\hline 394 & Hudson & 4222 & 495 & Sara Bernl & 4443 \\
\hline 395 & Cheney & 3734 & 496 & Ira Way... & 2907 \\
\hline 386 & Belle of Titusville. & 3428 & 497 & Golden Rule & 4429 \\
\hline 397 & Cavern & 2816 & 498 & Puritan No & 20235 \\
\hline 398 & Black Diamond N & 12828 & 499 & Oriental & 20235 \\
\hline 399 & Billy Bryan No. 2 & 12828 & 500 & Mexican.. & 4412 \\
\hline 400 & Black Diamond & 12828 & 503 & Blue Jay. & 20235 \\
\hline 403 & Billy Bryan N & 12828 & 504 & New York. & 1416 \\
\hline 404 & Whopper..... & 2938 & 505 & Grasshopper. & 20235 \\
\hline 405 & Teller.......... & 2937 & 506 & Ajax & 20384 \\
\hline 406 & Kanawha.... & 2927 & 507 & Climax..... & 20384 \\
\hline 407 & Providence... & 4858 & 508 & Lookout- & 20384 \\
\hline 408 & Mocking Bird. & 7211 & 509 & Lookout No. 3.-. & 20428 \\
\hline 409 & Dewey & 17909 & 510 & Lookout No. 5... & 20428 \\
\hline 410 & Dewey No. 2 & 17909 & 512 & Yelm & 7106 \\
\hline 413 & Limited....... & 17909 & 513 & Mountain & 4032 \\
\hline 414 & Bon Ton & 2836 & 514 & Lookout No. 4 & 20428 \\
\hline 415 & High Tide.... & 779 & 515 & Lookout No. 2 . & 20384 \\
\hline 416 & Carbonate.... & 6595 & 516 & Tyro........ & 20384 \\
\hline 417 & Crystal Moun & 778 & 517 & Zacatacus & 20427 \\
\hline .418 & International. & 2868 & 520 & Dixie Quee & 20428 \\
\hline 419 & Equinox......... & 7630 & 522 & Jenny Lynd. & 3566 \\
\hline 420 & Crystal..... & 3433 & 523 & Dixie Quee & 20384 \\
\hline 421 & Noon Tide... & 3432 & 524 & Shetland.. & 4037 \\
\hline 423 & Old Hamilton. & 5615 & 525 & Standard. & 6867 \\
\hline 424 & Crystal Mountai & 19862 & 526 & Soladad. - & 5652 \\
\hline 425 & Crystal Moun & 19862 & 527 & Centeral & 6867 \\
\hline 426 & Crystal Moun & 19802 & 528 & King of the West... & 20427 \\
\hline 427 & Justice........ & 7232 & 529 & Anna & 7082 \\
\hline 428 & Mountain Qu & 4113 & 530 & Osceola... & 20427 \\
\hline 430 & Ida $\mathrm{M}$ & 5088 & 532 & Echo....- & 7622 \\
\hline 433 & South Star... & 5088 & 533 & Duke of Wellington. & 20427 \\
\hline 434 & Minnesota... & 5088 & 534 & Grand View & 3475 \\
\hline 435 & Crown & 7892 & 535 & New Discovery....... & 20427 \\
\hline 436 & Crown No. 2. & 7892 & 536 & Indicator. & 11416 \\
\hline 437 & Crown No. 3 & 7892 & 537 & Toledo... & 5525 \\
\hline 438 & Crown Extensio & 7892 & 538 & May Flower. & 20384 \\
\hline 440 & Silent Star & 12826 & 539 & Cameron & 3863 \\
\hline 441 & Ella C................ & 17946 & 540 & Chesapeake... & 5068 \\
\hline 442 & Ella.......... & 4182 & 543 & Emma....... & 20427 \\
\hline 443 & Lone Star... & 3824 & 544 & Log Cabin... & 20427 \\
\hline 444 & Miller M. S. & 1370 & 54 & Setz No. 5 & 20427 \\
\hline 445 & M. S............... & $1367 \mathrm{~B}$ & 546 & Four X & 20427 \\
\hline 446 & Dan Harris $\mathrm{M}$. $\mathrm{S}$ & 1369 & 547 & Cora..... & 4838 \\
\hline 447 & Utah & 1368 & 548 & Rocket... & 20384 \\
\hline 448 & Cottage Hom & 12972 & 54 & Mancos. & 20384 \\
\hline 449 & Nevada...... & $1367 \mathrm{~A}$ & 55 & Homestake. & 20384 \\
\hline 450 & Lula............ & 3293 & 551 & Hiawatha... & 20384 \\
\hline 451 & Schofield Tor & & 553 & Setz No. 3 & 20427 \\
\hline 453 & May Flower. & 4197 & .554 & Setz No. 4 & 20427 \\
\hline 454 & Alice......... & 4196 & 555 & Setz No. 2. & 20384 \\
\hline 455 & Columbine No. 2 & 16753 & 556 & Setz & 20384 \\
\hline 456 & Columbine No. 1 & 16753 & 557 & Puritan No. 4. & 20235 \\
\hline 457 & Niagara ........ & 4911 & 558 & Puritan No. 1 . & 20325 \\
\hline 458 & Pitkin...... & 2906 & 559 & Puritan No. 13 & 20325 \\
\hline 459 & Greenback.. & 5481 & 560 & Puritan No. 3......... & 20235 \\
\hline 460 & New Discover & 5482 & 562 & Millsite... & 20324 \\
\hline 461 & Commonwealth Placer & 17347 & 563 & Puritan No. 2 & 20235 \\
\hline 463 & Shakespeare No. 7 & 16164 & 564 & Galena Park No. 1. & 19300 \\
\hline 2045 & Shakespeare No. 6 & 161 & 565 & Out West Placer. & 1309 \\
\hline 465 & Shakespeare No. $5 . .$. & 161 & 566 & Cleveland........................ & 15183 \\
\hline 466 & Shakespeare No. 4 & 161 & 56 & 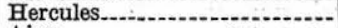 & 14154 \\
\hline 201 & Shakespeare No. 3 & 161 & 568 & $\mathrm{Aj} \mathrm{ix}$ & 14154 \\
\hline
\end{tabular}


Alphabetic index of claims shown on map (pl. 1)

\begin{tabular}{|c|c|c|c|c|c|}
\hline Name of claim & Patent no. & No, on map & Name of claim & Patent no. & No. on map \\
\hline Agatha........ & 10280 & 359 & C larke No. 2 & 3198 & 239 \\
\hline Ajax & 20384 & 506 & Clarke No. 3. & 3136 & 238 \\
\hline Ajax........... & 14154 & 568 & Cleopatra & $4187 \mathrm{~A}$ & 178 \\
\hline Albatross.. & 8601 & 75 & Cleveland. & 15183 & 566 \\
\hline Alice......... & 4196 & 454 & Climax..... & 20384 & 506 \\
\hline America........ & 7863 & $\begin{array}{l}234 \\
529\end{array}$ & Climax...- & $\begin{array}{l}7739 \\
4857\end{array}$ & 190 \\
\hline Anna.................. & $\begin{array}{l}7082 \\
8633\end{array}$ & $\begin{array}{l}529 \\
300\end{array}$ & Columbine $\mathrm{N}$ & $\begin{array}{r}4857 \\
16753\end{array}$ & $\begin{array}{l}470 \\
456\end{array}$ \\
\hline Aspen.No. 1 & 8633 & 298 & Columbine No. 2 & 16753 & 445 \\
\hline A.tlanta & $\begin{array}{l}7863 \\
3545\end{array}$ & 234 & Commonwealth ple & 17347 & 461 \\
\hline $\begin{array}{l}\text { Bald Eagle } \\
\text { Banker's Daughter. }\end{array}$ & $\begin{array}{l}3545 \\
8627\end{array}$ & $\begin{array}{l}226 \\
202\end{array}$ & $\begin{array}{l}\text { Condon } \\
\text { Copper King }\end{array}$ & $\begin{array}{l}6645 \\
6866\end{array}$ & $\begin{array}{r}93 \\
147\end{array}$ \\
\hline Banner & 6399A & 36 & Copper King I & 18606 & 345 \\
\hline $\begin{array}{l}\text { Banner M. S } \\
\text { Banner Placer }\end{array}$ & $\begin{array}{r}6250 \mathrm{~B} \\
7602\end{array}$ & $\begin{array}{l}8 \\
7\end{array}$ & 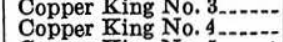 & $\begin{array}{l}18606 \\
18606\end{array}$ & $\begin{array}{l}344 \\
343\end{array}$ \\
\hline ar Mountain I & 13621 & 265 & Copper King No. 5 & 18606 & 346 \\
\hline $\begin{array}{l}\text { Bear Mountain No. } 2 \\
\text { Bear Mountain No. } 3\end{array}$ & $\begin{array}{l}13621 \\
13621\end{array}$ & $\begin{array}{l}266 \\
267\end{array}$ & $\begin{array}{l}\text { Copper King No. 6.... } \\
\text { Copper King No. } 7 . \ldots\end{array}$ & $\begin{array}{l}18606 \\
18606\end{array}$ & $\begin{array}{l}347 \\
339\end{array}$ \\
\hline Bear Mountain No. $4=$ & 13621 & 268 & Copper King No. 8 & 18606 & 334 \\
\hline $\sin$ No. 5 & $\begin{array}{l}13621 \\
13621\end{array}$ & 269 & Copper King N & $\begin{array}{l}18606 \\
18606\end{array}$ & $\begin{array}{l}333 \\
335\end{array}$ \\
\hline $\begin{array}{l}\text { ain No. } 6 \ldots \\
\text { ain No. } 7 \text {. }\end{array}$ & $\begin{array}{l}13621 \\
13621\end{array}$ & $\begin{array}{l}270 \\
306\end{array}$ & Copper King No. 11..... & $\begin{array}{l}18000 \\
18606\end{array}$ & 329 \\
\hline Bear Moun & 13621 & 307 & Copper King No. 12 & 18606 & 330 \\
\hline ar Mo & 13621 & 308 & Copper King & 18606 & 328 \\
\hline .10 & 13621 & 309 & Cora & $\begin{array}{r}4838 \\
-17707\end{array}$ & 547 \\
\hline $.11-\ldots$ & 13621 & 310 & Corwen Pl & 17727 & 44 \\
\hline 13 & 13621 & 304 & Cottage Home & 12972 & $\begin{array}{l}448 \\
435\end{array}$ \\
\hline $14=$ & 13621 & 305 & $\begin{array}{l}\text { Crown } \\
\text { Crown No.2... }\end{array}$ & $\begin{array}{l}7892 \\
7892\end{array}$ & $\begin{array}{l}435 \\
436\end{array}$ \\
\hline $\begin{array}{l}14.5 \\
15\end{array}$ & $\begin{array}{l}13621 \\
13621\end{array}$ & $\begin{array}{l}311 \\
287\end{array}$ & $\begin{array}{l}\text { Crown No. } 2 .- \\
\text { Crown No. } 3 .-\end{array}$ & $\begin{array}{l}7892 \\
7892\end{array}$ & $\begin{array}{l}436 \\
437\end{array}$ \\
\hline-16 & 13621 & 286 & Crown Extension. & 7892 & 438 \\
\hline $17=$ & 13621 & 285 & Crystal & 3433 & 420 \\
\hline $18 \ldots$ & 13621 & 279 & Cry'stal Mc & 778 & 417 \\
\hline $19 \therefore$ & 13621 & 278 & Crystal Moun & 19862 & 426 \\
\hline in. No. $20 \ldots$ & 13621 & 277 & Crystal Mountai & 19862 & 288 \\
\hline 21 & 13621 & 276 & Crystal Mo & 19862 & 290 \\
\hline 22 & 13621 & 275 & $\begin{array}{l}\text { Crystal Mo } \\
\text { Crystal Mo }\end{array}$ & $\begin{array}{l}19862 \\
19862\end{array}$ & $\begin{array}{l}289 \\
425\end{array}$ \\
\hline 24 & $\begin{array}{l}13621 \\
13621\end{array}$ & $\begin{array}{l}274 \\
273\end{array}$ & Crystal Mo & 19862 & 424 \\
\hline & 13621 & 284 & Crystal Cit & 8581 & 258 \\
\hline & 13621 & 283 & Crystal Ci & 8581 & 259 \\
\hline B & 5593 & 203 & Crystal Ci & 8581 & 257 \\
\hline & 3773 & 390 & C & $5708 \mathrm{~B}$ & 323 \\
\hline $\mathrm{S}$ & 9697 & 393 & Crysta & 6471 & 127 \\
\hline$\ldots$ & & 396 & Curbstone... & $6339 \mathrm{~A}$ & $\begin{array}{r}40 \\
258\end{array}$ \\
\hline & 5709 & 386 & Daisy.- & 10280 & 358 \\
\hline & 4474 & 66 & -...- & 7655 & 163 \\
\hline B & 5707 & 373 & $\cdots$ & 10280 & $\begin{array}{l}366 \\
188\end{array}$ \\
\hline 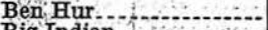 & $6471^{\circ}$ & 126 & Dalton... & 4189 & $\begin{array}{l}188 \\
446\end{array}$ \\
\hline & 4068 & 186 & Dan Harris M. & 1369 & $\begin{array}{l}440 \\
356\end{array}$ \\
\hline Billy Bry & 12828 & 403 & Denver City.-. & $\begin{array}{r}9929 \\
17909\end{array}$ & $\begin{array}{l}300 \\
409\end{array}$ \\
\hline $\begin{array}{l}\text { Billy Bry } \\
\text { Black Bi }\end{array}$ & $\begin{array}{r}12828 \\
6329\end{array}$ & $\begin{array}{l}399 \\
153\end{array}$ & No. 2 & $\begin{array}{l}17909 \\
17909\end{array}$ & 410 \\
\hline $\begin{array}{l}\text { B1 } \\
\text { B1 }\end{array}$ & $\begin{array}{r}6329 \\
12828\end{array}$ & $\begin{array}{l}153 \\
398\end{array}$ & $\begin{array}{l}\text { Dewey No. } \\
\text { Diadema.- }\end{array}$ & 17909 & 216 \\
\hline Black D & 12828 & $\begin{array}{l}398 \\
400\end{array}$ & Dixie Queen & 20384 & 523 \\
\hline & 6329 & 151 & Dixie Queen No & 20428 & 520 \\
\hline & 7863 & 230 & olomit & 4530 & 56 \\
\hline & 12228 & 3 & Dora & 6645 & $\begin{array}{r}89 \\
523\end{array}$ \\
\hline B1 & 5783 & 166 & Duke of Wellington..... & 20427 & 533 \\
\hline & 20235 & 503 & namite........ & 7655 & $\begin{array}{r}200 \\
37\end{array}$ \\
\hline & 4411 & 45 & Eagle... & $6339 \mathrm{~A}$ & 104 \\
\hline & 6463 & 105 & le.... & 5587 & 355 \\
\hline $\mathbf{B}$ & 2836 & 414 & Eaton.- & 2957 & $\begin{array}{l}300 \\
532\end{array}$ \\
\hline 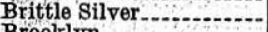 & 3636 & 225 & Echo & $\begin{array}{r}7222 \\
\mathrm{Am}\end{array}$ & 364 \\
\hline $\begin{array}{l}\text { B } \\
\text { B }\end{array}$ & 6471 & 12 & El Dorado... & $3117 \underset{4182}{\text { Am }}$ & 442 \\
\hline$\stackrel{\mathrm{Br}}{\mathrm{B}}$ & $\begin{array}{l}4066 \\
7950\end{array}$ & 194 & Ella & $\begin{array}{r}4182 \\
17946\end{array}$ & 441 \\
\hline $\mathrm{Br}$ & $\begin{array}{l}7950 \\
7950\end{array}$ & $\begin{array}{l}360 \\
361\end{array}$ & $\begin{array}{l}\text { Ella C. } \\
\text { El Negocio }\end{array}$ & $\begin{array}{l}17946 \\
15329\end{array}$ & 353 \\
\hline Bi & 12098 & $\begin{array}{l}361 \\
256\end{array}$ & Emma & 20427 & 543 \\
\hline & 12588 & 389 & Emperor... & 4530 & \\
\hline & 3863 & 53 & Empress... & 4530 & $\begin{array}{r}64 \\
10\end{array}$ \\
\hline & 6595 & $4 \mathrm{I}$ & Equinox.... & 7630 & 419 \\
\hline & 2671 & 23 & & 6410 & 204 \\
\hline & 8581 & 26 & ing Star... & 345 & $\begin{array}{l}207 \\
173\end{array}$ \\
\hline & & 12 & elsior No. 1.......... & 430 & 388 \\
\hline & & 39 & Extension & 9929 & 108 \\
\hline & 6867 & 52 & Extension & 13293 & 109 \\
\hline Charlotte. & 8601 & 84 & Extension No. 1........... & 13293 & 38 \\
\hline Cheney.... & 3734 & 395 & Falcon & $6339 \mathrm{~A}$ & 200 \\
\hline Chesapeak & $\begin{array}{l}5068 \\
7849\end{array}$ & $\begin{array}{l}540 \\
313\end{array}$ & Fargo & $\begin{array}{r}5538 \\
5710 \mathrm{~A}\end{array}$ & 375 \\
\hline 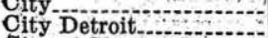 & $\begin{array}{l}7849 \\
8641\end{array}$ & $\begin{array}{l}313 \\
200\end{array}$ & $\begin{array}{l}\text { F. G. Richardson } \\
\text { F. G. Richardson M. S.- }\end{array}$ & $5710 \mathrm{~B}$ & 384 \\
\hline & 3387 & 20 & Fine Marble Placer...... & 8601 & \\
\hline 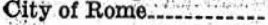 & 8601 & & Flag & & \\
\hline
\end{tabular}


Alphabetic index of claims shown on map (pl. 1)-Continued

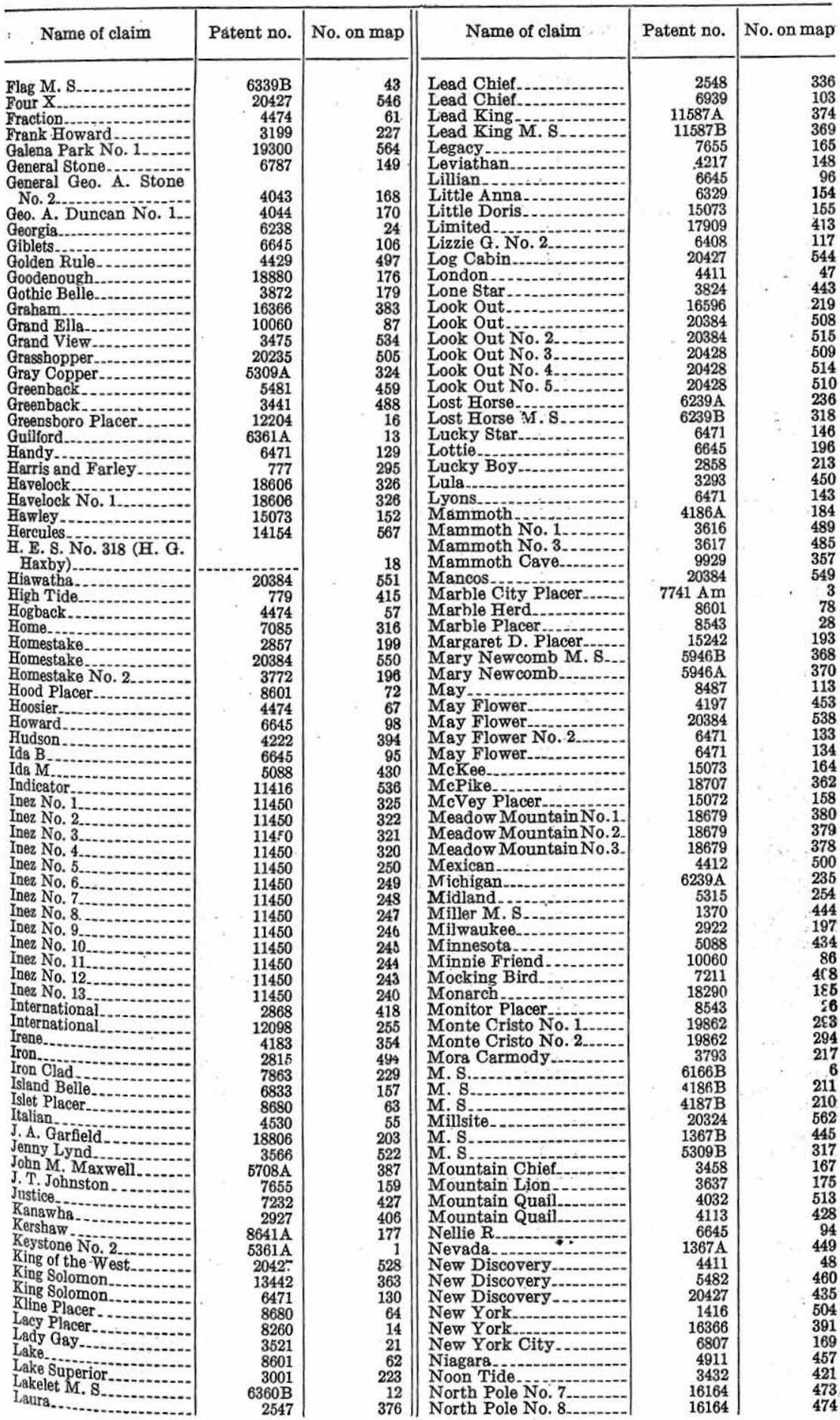


SNOWMASS MOUNTAIN AREA, COLORADO

Alphabetic index of claims shown on map (pl. 1)-Continued

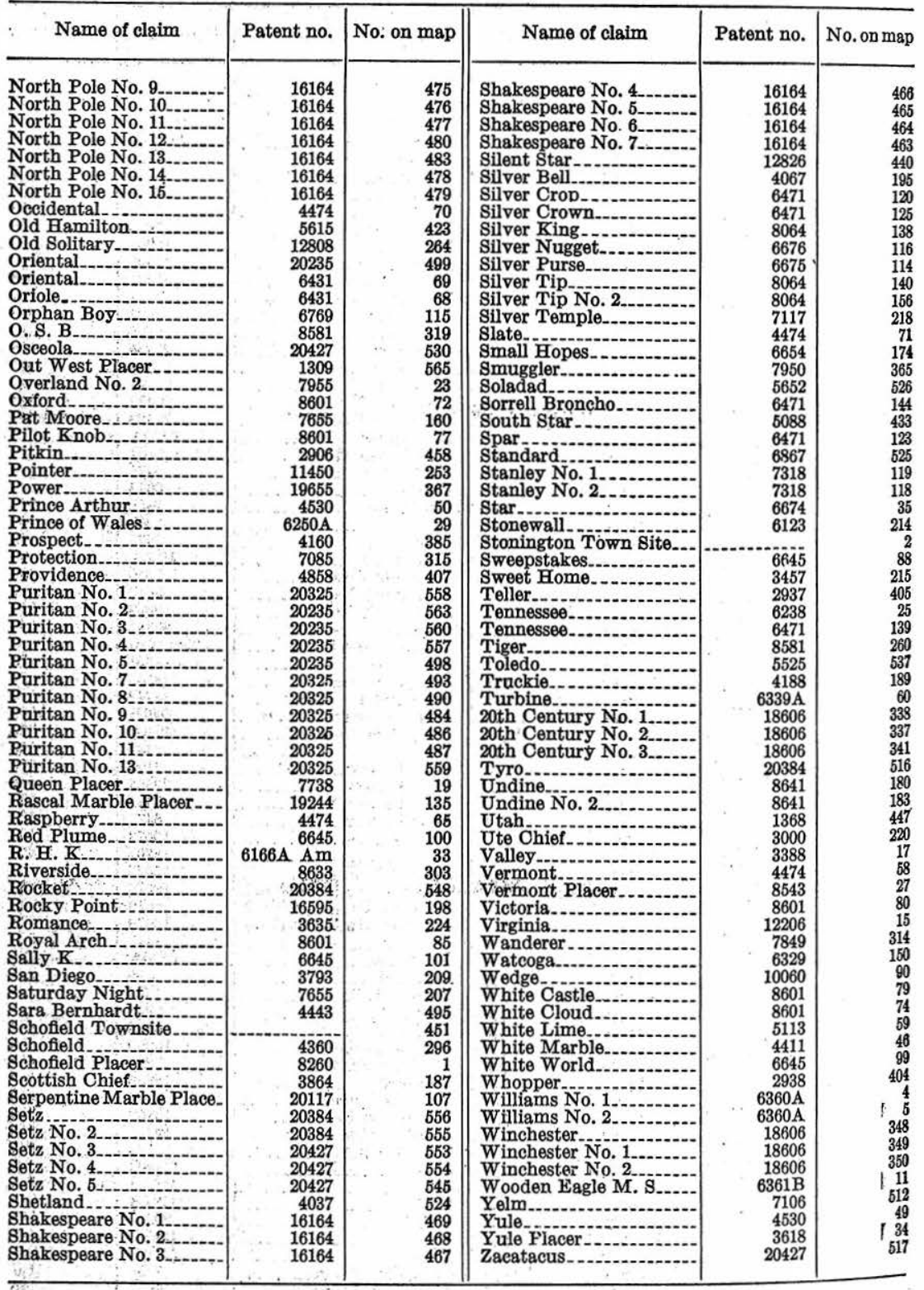




\section{INDEX}

A

Abstract

Accessibility of area_-_-_--_--

Acknowledgments

Adularia, occurrence of

Ajax mine. See Hercules-Ajax mine.

Albite granite, alteration of

chemical analyses of

distribution and character of

Aplite, occurrence of

Aragonite, occurrence of

Argentite, occurrence of -

\section{B}

Barite, occurrence of

Baroni, John, tunnel, features of --.

Bear Basin, granite contact in

Bear Mountain tunnel, features of -.--

Belle of Titusville prospect, features

$$
\text { of - }
$$

Bennet tunnel, features of _-_____- 151

Black Eagle mine, features of---- 114-115

Black Queen mine, assays of gold

from_- 115

character of rock of

early production from.-. 100-101

features of -_._-________._ 115-117

Blue Jay tunnel, features of _-_._-_- 142

Brooklyn tunnel, features of -..--_-- 143

Buildings, representative, containing Yule Colorado marble_- 172173, pls. 21-23

Bureau of Standards, tests by Burt prospect, features of

\section{C}

Calcite, occurrence of _-___-_ 75, 103-104 Cambrian system, correlation of Sawatch quartzite, formation of _ 12

Catalpa mine, features

Cerusite;

104

Chaffee formation, character and thickness of - $12,16-18$

correlation of -

distribution of

mineralization of

Chalcocite, occulron 135

Chalcopyrite, occurrence of 104

Chrysocolla, occurrence of

Claims, list of patented_-_-_ 175-180, pl. 1

Climate -

Cretaceous formations, features of -- 37.-

40, pls. 6, 7

Crystal Mountain tunnel, features of - 136-137
$D$ Page $129-130$

Daisy prospect, features of
Dakota (?) quartzite, character and thickness of -

distribution of

faulting of -

mineralization of

$129,131,142-145$

section of

used as horizon marker_-_-_._- 93

Devonian system, correlation of _-_- 30-32

Chaffee formation of _-_ 12, 16-18, pl. 2

marble deposits in 174

Devonian-Mississippian boundary, features of

Dikes and sills, correlation of early, northeast trend of-_-_-_-- 82-83 metamorphism in

rocks composing -_-_____-_._-_ 41-44

Diopside, occurrence of _-_____- $75, \mathrm{pl} .11$

Dolomite, metamorphism of -_-- 74-75, pl. 11

Dyer dolomite member of Chaffee formation, character and thickness of correlation of section of

\section{E}

Elk Mountain fault zone, features of - $83-85$, pls. $1,6,14,15$ movement in northward extension of --- 86-90, pl. 10 relative age of -

Elk Mountains stock, correlation of -- 69-70 Entrada sandstone, age and correlation of - $34-35$

alteration of _-_._. 73

character and thickness of distribution of

Eureka mine, character of rock of --_- 112 early production from_-_-_-_-_ 100 features of

Evening Star prospect, features of -- 117

\section{F}

Fairchild, J. G., chemical analyses by_-__- $47,55,56,58,60,62$

Farley. See Harris-Farley.

Faults, featureś of -__- 83-92, 93-95, pls. $1,6,10,14$ influence of, on metamorphism_- 79 sumimary of Field work Fluorite, occurrence of -___-_-_ 104 
Fremont limestone, character and
thickness of $\begin{array}{r}\text { Page } \\ \text { correlation of } \\ \text { distribution of } \\ \text { marble deposits in } \\ \text { section of }\end{array}$

\section{G}

Gabbro porphyry, character and distribution of -

Galena, occurrence of -_-_._ 104-105, pl. 18 Galena Mountain, prospects on _._._- 141-

143, pl. 1

Geologic map pl. 1

Geology, general features of $9, \mathrm{pl} .1$

Geomorphology, general features of -.- 5-6 Girty, G. H., fossils identifled by--_- 24-25 Glaciation, depositional features of -.- 96

97, pl. 1

erosional features of - 97-100, pls. 13, 17 rock terraces due to Gneiss, pre-Cambrian, slight metamorphism of

Gold, occurrence of

Gold Pan vein, features of

Granite, character of

conclusions regarding

metamorphism by intrusion of.. 50, pl. 1 mode of occurrence of _- 48-50, pls. 1, 7 pegmatites, aplites, and porphyritic marginal facies in.

relative age and correlation of -- 51-52

Granodiorite, chemical analyses of _-- 58, 62 changes in, from margin toward center

59-64

contact of, with maroon grits_ pls. 9, iv correlation of -_-_______- 69-70 distribution and character of --- 57-59 location and access of _.... 52, pls. 1, 6 mode of occurrence of. $68-69$, pls. 9-10 origin of albite and other rock varieties in relation of, to neighboring stocks___. 52-53

structural and textural features of

Gunnison formation, rejection of name of

\section{H}

Harding quartzite, alteration of -.-character and thickness of $12,15-16$ correlation of section of

Harris-Farley group of veins, tunnel intersecting - 136

workings on

Hedenbergite, occurrence of _..._._. 105

Hercules-Ajax mine, features of _.-.-- 146

Hermosa (?) formation, age of --_-- 26 alteration in character and thickness of -..- 12, 22. 26 , pls. 3,4 correlation of
Hermosa (?) formation, distribution of -

effect of metamorphism on _-...- 77 granite cutting across---_------ pl.8 marble deposits in _._._._. 174, pl. 4 metamorphic minerals in minerulization of _..._... 114-115, $119,132,137,139-140,149$

sections of -

High Tide veins, workings on _...- 138

Họmestake tunnel, features of...-.- 142

\section{I}

Inez tunnel, features of

$119-121$

Jack Wacker claims, features of -_._ 134

John Baroni tunnel, features of _.... 146

Jurassic rocks, formations of - 33-37, pls. 1, 6 mineralization of _._._._- 136, 131, 149

$\mathbf{K}$

Ketchum, Milo S., tests by 161

L

Lamprophyric rocks, alteration of --_ 44 character of relative age of

Lead Bullet prospect, features of -- 134-135

Lead King mine, character of rock of 112 early production from___._._ 100-101 general features of location of _._._. smelter returns of shipments Wilfley table test of material table test of material 126 Leadville limestone, alteration of - $71,7 \bar{\jmath}-$ 76. pi. 12

character and thickness of -..-- 12 correlation of distribution and character of 21 , pls. $1-3$ granite cutting across_____-_ 49, pl. 8 marble coextensive with_ 150-157, 78 metamorphic minerals in_._-_ 18 section of 20

"Lime", occurrence of, in quarries of Yule Colorado marble_- 76, pl. 12 Limestone, metamorphism of 77, pls. 12,13

Lizard Lake prospect, features of -.-- 121 Location of area_M

Malachite, occurrence of _-_._-_ 105-106

Mancos shale, age and correlation of 40 alteration of character and thickness of -.- 40, pl. 7 distribution of 
Mancos shale, metamorphism along fault zone in 79 , pl. 6 mineralization of -_-_____-_ 118, 127 , $130,143-146,150-151$

Manitou dolomite, character and thickness of

correlation of

distribution of marble deposits in _..._. 173-174, pl. 11 mineralization of _._._._._._. 134 section of 15 Eerpentine in__-_-_._._. 74-75, pl. 11

Marble, aging of _._. 171 deposits of, features of features of formation constituting - pls. $3,19,20,21,22$

grades of -

reserves of

171

Maroon formation, character and thickness of _-_ 12, 27-29, pl. 5 contact of, with granodiorite-_- 68 , pls. 9,10

correlation of distribution of effect of metamorphism on
faulting of metamorphic minerals in metamorphic minerals in $-[\overline{78-79}$ section of

Mesozoic sedimentary rocks, formations of _._- $33-40$, pls. 1, 6, 7

Metamorphism, contact, general features of ______ 70-71

contact, marble formed by 70

influence of structure on of sedimentary rocks, by granite intrusion--.. $50, \mathrm{pl} .1$ origin of silicates contributing to $79-80$ summary of

Mexican Cut, character of rock of - 112 features of - 141-142

Mulwaukee-Undine group of prospects, features of _.___ 122--123

Mineral Point, mines and prospects on_- 129-132

Mineralization, history of

Minerals, character of deposits of in bedded replacement deposits $\quad 110$ in vein deposits_______ 109-110 occurrence of

Malsolssippian series, formation of 12 , 19-21, pls. 1, 2 formation of, correlation of - $31-$; 2 marble deposits in

Mlssissippian-Devonian boundary, features of -

Molybdenite, occurrences of _._ 106, 151-152 Morrison formation, age and correlation of ..........-.

alteration character and thickness of 71,73 faulting of ......... 84-86 mineralization of section of used as horizon marker
Mount Sopris, rock of, correlation

$$
\text { of - N }
$$

Niobrara formation, mineralization of_-_._-_ 119, 125, 144-145

North Pole mine, character of rock<smiles>[14CH2]CC#C[GeH2]</smiles>
production from_-_._-_ 100-101, 139 workings of _..._. 139

\section{0}

Ordovician system, formations of $12,14-16$ formations of, correlation of _._- $30-31$ marble deposits in -._-_ 173-174, pl. 11

Ore deposits, character of _._._._. 108-111 future prospecting for._._._._. 113-114 location of minerals of --_---- 103-108, plş. 18-20 rocks containing, character and composition of 112 summary of _..._. 100-103 zoning of

Paleozoic rocks, formations of - 12 formations of, correlation of ---- 29-32 metamorphism of _._._._._._._. 11-12 regional setting of _..._..._._. 10-11

Paradise Pass, prospecting in vicinity of - Parting member of Chaffee formation, character and thickness of

$12,16-18$

correlation of mineralization of _.__ $134,135,149-150$ section of

Pegmatites, occurrence of, in granite of Treasure Mountain stock

Pennsylvanian series, formation of -- 12

formations of, correlation of $\quad \begin{array}{r}21-26 \\ 32\end{array}$ marble deposits in Pennsylvanian (?) series, formation of _- 12, 26-29

Permian series, formation of -..-- 12, 26-29 formation of, correlation of ---- 32 Pioneer tunnel, features of _-___._. 123 Porphyritic marginal facies, occurrence of, in granite_--- 50

Pre-Cambrian gneiss, distribution and general features of $-9-10, \mathrm{pl} .1$

Pre-Jurassic unconformity, features of -_. $81-82$, pl. 14

Previous work

Pyrite, occurrence of

Pyrrbotite, occurrence of

\section{Q}

Quartz, occurrence of Quartz diorite, chemical analysis of _. $\quad 55$ distribution and character of -.- 53-55 Quartz monzonite porphyry, character and distribution of - 42-43 Quartzite, slight metamorphism of -- 73-74 


\section{R}

Reeside, J. B., Jr., fossils identified$$
\text { by }
$$

Rockett tunnel, features of

\section{$\mathbf{s}$}

Sawatch quartzite, alteration of character and thickness of correlation ofdistribution of section of 31 12-13, pl. 1 13-14, pl. 2

Schofield Park, mines and prospects in

143-148

Serpentine, occurrence of____ 74-75, pl. 11 Shale, metamorphism of

Sheep Mountain, mines and prospects on

Sheep Mountain tunnel, features of_ 123-125 Sills. See Dikes and sills.

Silver, occurrence of 106-107

Skyline prospect, features of

Snowmass Mountain. stock, changes in, adjacent to calcareous beds

changes in, adjacent to feld-

spathic beds_-
granodiorite of, changes in, from margin toward center_- 59-64

location and aceess of - 52, pls. 1,6 relation of, to neighboring stocks

mode of occurrence of

origin of albite granite and other rocks in

64-67

rock varieties of 53-59

slight metamorphism by structural and textural features of $59-60$, pl. 6

Specularite, occurrence of 107 , pl. 18

Sphalerite, occurrence of 107, pl. 18

Strauss quarry, character of marble in

157 features of

163-164

Structure, general features of influence of, on metamorphism - 78-79

\section{$\mathbf{T}$}

Tennessee of the Black Queen group, features of

Tertiary rocks, description of $40-70$ structure of ___ 82-96 summary of

Tetrahedrite, occurrence of $107-108$

Tomb of the Unknown Soldier, block for, from Yule Colorado márble

Treasure Mountain, prospects on _-_ 132-136 Treasure Mountain dome, size and form of____ 92-93, pls. 1, 16 faults associated with relative age of _._-_____-_ 95-96 Treasure Mountain stock, alteration$$
\text { around _-_._._........ }
$$

contact metamoripism granite of
Treasure Mountain stock, granite of, conclusions regarding -- 50-51 mode of occurrence of-- 48-50, pls. 1, 7 relative age and correlation of

Treasury Mountain, mine and prospect on_-_-_-_-_ 148-150

\section{U}

Unconformity, pre-Jurassic, features of _-_._. 81-82, pl. 14

Undine group. See Milwaukee-Undine group.

Unknown Soldier. See Tomb of Unknown Soldier.

\section{V}

Vegetation 6-7

Vermont Marble Co., tests by.....- 163

$$
\text { W }
$$

Warrior tunnel. See Ploneer tunnel. West Elk Mountain, correlation of--

White Rock Mountain stock, correlation of

metamorphism by

Whopper : fault, detailed description of

Whopper lode, assays of samples of -- 145

from
features of

\section{$\mathbf{Y}$}

Yule Colorado marble, aging of block for Tomb of Unknown Soldier._- 169 buildings containing character and thickness of chemical analyses of commercial outlook for.___._- 163 distribution of features of fractures in grades of "lime" in quarries of _-_..- 76, pl. 12 origin of physical properties of -...-_ 160-163 quarries and prospects in reports on tests on $160-162$

Yule Colorado marble quarry, character of marble in_._- $157-$

history and development of -.- 153 location of nature and size of outcrop at.- 164165, pl. 24

Yule Creek, prospects at head of -- 149-150 Yule Creek prospect; features of -- 135-136 Yule golden vein marble, features of - 170 , pls. 21

Yule veined statuary marble, features

1
45
4


The use of the subjoined mailing label to return this report will be official business, and no postage stamps will be required

UNITED STATES DEPARTMENT OF THE INTERIOR GEOLOGICAL SURVEY

This label can be used only for returning official publications. The address must not be changed.

PENALTY FOR PRIVATE USE TO AVOID PAYMENT OF POSTAGE, $\$ 300$

\section{GEOLOGICAL SURVEY,}




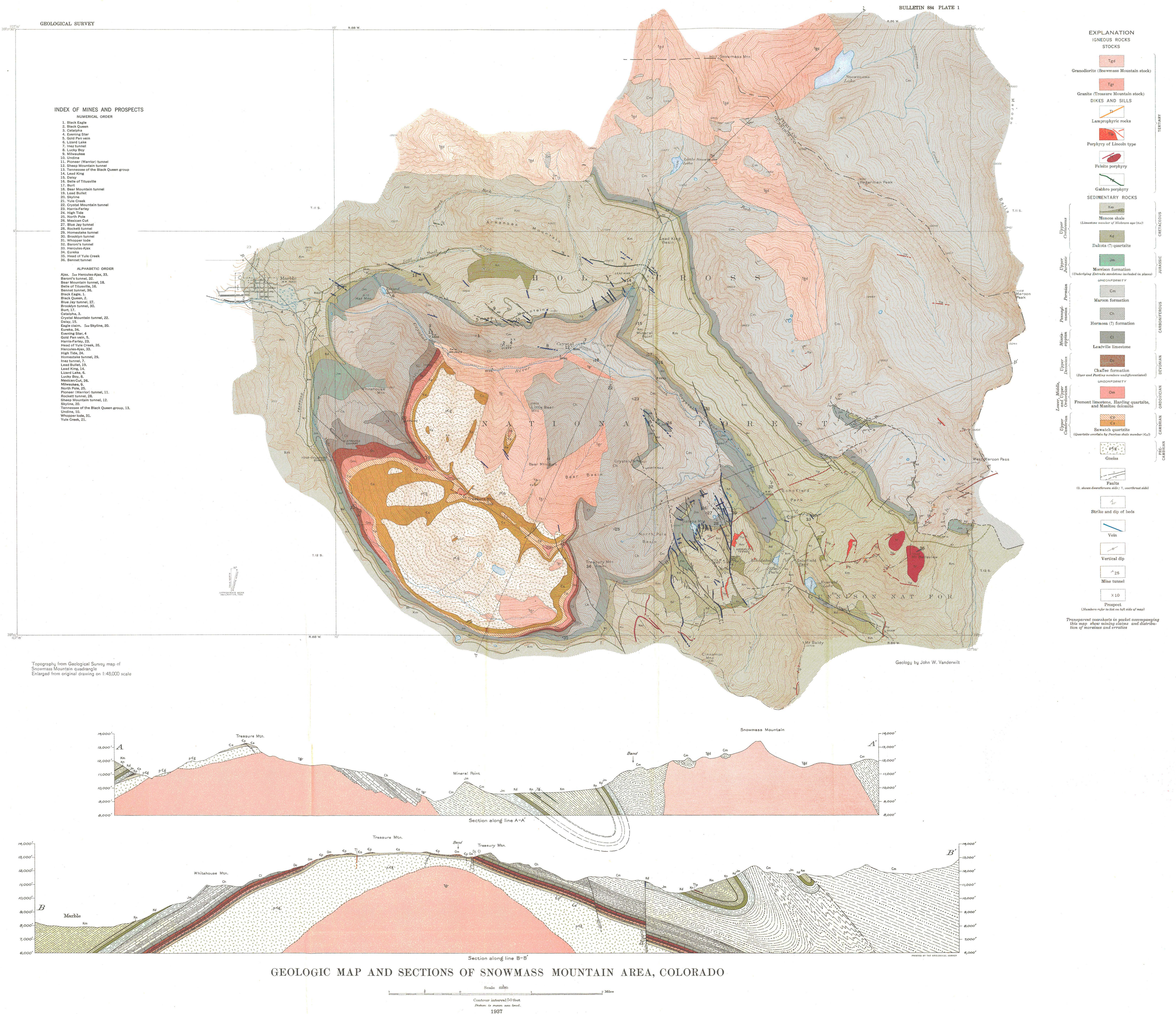




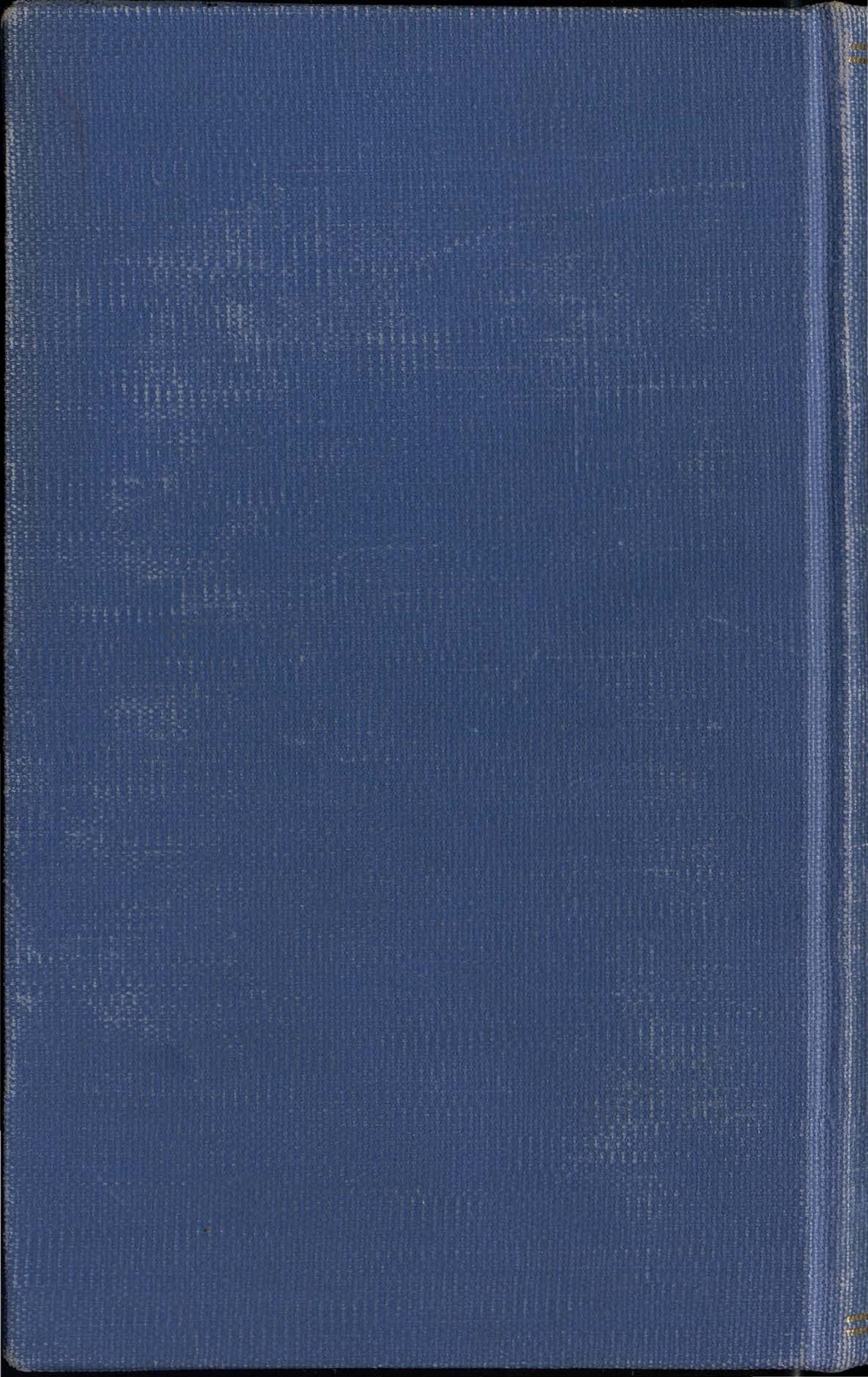

